\title{
um palácio em formação
}

ESTUDOS SOBRE O DESENVOLVIMENTO DO PROJETO DO PALÁCIO ITAMARATY ENTRE 1959 E 1970

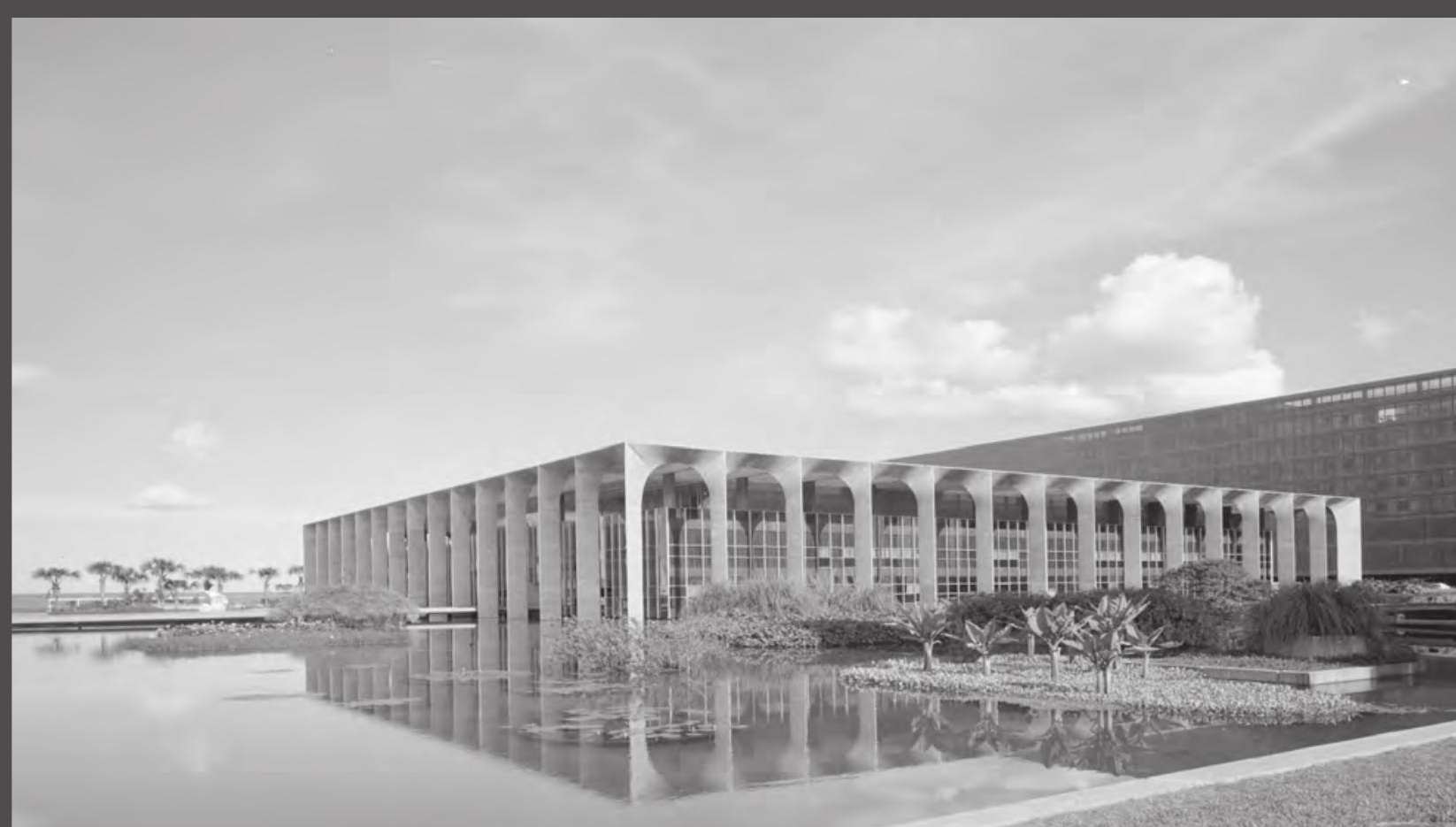

KAREN AKEMI MATSUDA

SÃO PAULO

2020 
KAREN AKEMI MATSUDA

\section{um palácio em formação}

ESTUDOS SOBRE O DESENVOLVIMENTO DO PROJETO DO

PALÁCIO ITAMARATY ENTRE 1959 E 1970

Dissertação apresentada ao Programa de Pós-Graduação da Faculdade de Arquitetura e Urbanismo da Universidade de São Paulo para obtenção do título de Mestre.

Área de Concentração

Projeto de Arquitetura

Orientadora

Profa. Dra. Tatiana Sakurai

Exemplar revisado e alterado em relação à versão original, sob responsabilidade da autora e anuência da orientadora. O original está disponível na sede do programa.

São Paulo 
Autorizo a reprodução e divulgação total ou parcial deste trabalho, por qualquer meio convencional ou eletrônico, para fins de estudo e pesquisa, desde que citada a fonte.

e-mail: karenamatsuda@gmail.com

Catalogação na Publicação

Serviço Técnico de Biblioteca

Faculdade de Arquitetura e Urbanismo da Universidade de São Paulo

Matsuda, Karen Akemi

Um palácio em formação: estudos sobre o desenvolvimento do projeto do Palácio Itamaraty entre 1959 e 1970 / Karen Akemi Matsuda; orientadora Tatiana Sakurai. - São Paulo, 2020 .

$208 \mathrm{p}$.

Dissertação (Mestrado) - Faculdade de Arquitetura e Urbanismo da Universidade de são Paulo. Área de concentração: Projeto da Arquitetura.

1. Arquitetura Moderna. 2. Projeto de Arquitetura. 3. Arquitetura de Interiores. I. Sakurai, Tatiana, orient. II. Título.

Elaborada eletronicamente através do formulário disponível em: $<$ http://www.fau.usp.br/fichacatalografica/ $>$ 
FICHA DE AVALIAÇÃO

NOME Karen Akemi Matsuda

TíTULO Um palácio em formação: estudos sobre o desenvolvimento do Palácio Itamaraty entre 1959 e 1970

Dissertação apresentada ao Programa de Pós-Graduação da Faculdade de Arquitetura e Urbanismo da Universidade de São Paulo para obtenção do título de Mestre.

APROVADO EM

BANCA EXAMINADORA

PROF. DR.

INSTITUIÇÃO

JULGAMENTO

PROF. DR.

INSTITUIÇÃO

JULGAMENTO

PROF. DR.

INSTITUIÇÃO

JULGAMENTO 
Imagem da capa: Palácio Itamaraty, Marcel Gautherot (ca. 1968).

Fonte: Acervo Instituto Moreira Salles. 
Para a lembrança de Adélia 


\section{AGRADECIMENTOS}

Agradeço à Coordenação de Aperfeiçoamento de Pessoal de Nível Superior (Capes) pela Bolsa de Mestrado que financiou esta pesquisa.

Este trabalho é fruto de incontáveis conversas e descobertas. Em especial, agradeço a minha orientadora, professora Tatiana Sakurai, com quem dividi alegrias e inquietações, pela orientação constante e pela leitura atenta deste trabalho.

Aos professores Maria Cecilia Loschiavo dos Santos e Rafael Perrone, pelas contribuições generosas durante a banca de qualificação do mestrado e por incentivar esta pesquisa. Aos professores Hugo Segawa, Mônica Junqueira de Camargo e Ivo Giroto, pela generosidade ao compartilhar o ambiente estimulante da sala de aula.

Rodrigo Queiroz e Sophia Telles, agradeço pelas conversas e pelo ensino do olhar.

Eduardo Rossetti e Graça Ramos, agradeço pelo diálogo sobre o Palácio Itamaraty e suas possibilidades. Juliana Braga, pela leitura estimulante deste trabalho.

Aos colegas pesquisadores: Aline de Figueirôa, Amanda Carvalho, Bruno Mentone, Cristina Dias, Elisa Tupiná, Ingrid Quintana, Márcio Reis, Marina Amado, Pedro Sunye e Rosane Piccolo, agradeço pelas discussões ao longo dos anos.

Aos responsáveis pelos arquivos e acervos consultados, que tornaram possível esta pesquisa, em especial, agradeço a Angela Figueiredo, responsável pelo Acervo Bernardo Figueiredo, Ana Cristina Ramos, responsável pelo Acervo do Arquiteto Milton Ramos, Naiade Margonar, do Acervo do Itaú Cultural, Laura Rodríguez, do Arquivo do Museu de Arte Brasileira da Faculdade Armando Alvares Penteado, Bruno Cezar Mesquita Esteves, do Arquivo Histórico do Museu de Arte de São Paulo (MASP), 
Marcele Souto Yakabi, do Arquivo Histórico Wanda Svevo da Fundação Bienal de São Paulo, Vinícius Marangon, do Instituto de Arte Contemporânea (IAC), Thaiane, do setor de fotografias do Instituto Moreira Salles (IMS), Dimitri Buriti, do Instituto Sergio Rodrigues, Guilherme Henrique Borges Stuckert Junior, do IPHAN-DF, Mariana Gomes, do Museu Histórico e Diplomático, Isabela Ono e Tatiana Leiner, do Instituto Burle Marx, Valéria Maria Lopes Cabral, da Fundação Athos Bulcão. A Nadir Borges Luz e Pedro Antunes, do Setor de Arquitetura do Ministério das Relações Exteriores, que tanto acreditaram e estimularam esta pesquisa.

Agradeço a Esther Stiller e a Emanoel Araujo, por dividirem histórias sobre o Itamaraty, e a Graça Bueno, por compartilhar suas memórias e conhecimento. Também agradeço a Rose Gonçalves, Ana Salerno, Andréia França e Giovanna Verdini.

Helen Tambolim por me receber tão bem no Rio de Janeiro e a Lucy Matsuda e Roberto Duarte, pela recepção calorosa em Brasília.

Aos amigos e amigas que foram absolutamente essenciais a este processo: Camila Neri, pela diagramação deste trabalho e Larissa Candro, pelo tratamento das imagens. Mas, sobretudo, agradeço nossas conversas acolhedoras. Gustavo Marques, por compartilhar comigo seu olhar e pelo apoio constante. Aos historiadores Fernando Dizzio e Rafael Cardoso, pelas conversas estimulantes e as críticas sempre tão generosas. Jéssica Bovo e Rodrigo Ajauskas, agradeço pela ajuda nas tabelas e pela amizade. Gabrielle Ferrara, Karen da Cruz, Victor Braga, Raisa Nierotka, Luana Caldarelli e Nivea Rosignoli, amigas queridas, pela escuta sobre este trabalho e pelas alegrias compartilhadas. Mirrah Iañez, pelas indicações precisas. Marcela Isnard e Gabriela Costa, pelo carinho e pelos infinitos gestos de amizade.

Por fim, para Edson, Edwiges, Renan e Leila, nenhuma palavra seria suficiente. 
FÁBULA DE UM ARQUITETO 
"A arquitetura como construir portas, de abrir; ou como construir o aberto; construir, não como ilhar e prender, nem construir como fechar secretos; construir portas abertas, em portas; casas exclusivamente portas e teto. $O$ arquiteto: o que abre para o homem (tudo se sanearia desde casas abertas) portas por-onde, jamais portascontra; por onde, livres: ar luz razão certa."

João Cabral de Melo Neto

Publicado no livro A educação pela pedra (1966).

In: MELO NETO, João Cabral de. Obra completa: volume único. Org. Marly de Oliveira. Rio de Janeiro: Nova Aguilar, 1994. pp.345-346. 



\section{RESUMO}

Esta dissertação de mestrado analisa o processo de projeto do Palácio Itamaraty, em Brasília, entre os anos de 1959 e 1970, a partir do levantamento das fontes primárias, como projetos, fotografias, jornais, revistas, relatos e relatórios de modo a fazer uma leitura cruzada entre os documentos. O objetivo é compreender o que era desejado e concebido à época da execução do projeto. Para tal, algumas questões que envolveram o projeto são apresentadas, como a importância da transferência do Ministério das Relações Exteriores para a consolidação de Brasília e a escolha do nome para o palácio. Por fim, discute a formação dos espaços palacianos.

PALAVRAS-CHAVE: 1. Arquitetura Moderna; 2. Projeto de Arquitetura; 3. Arquitetura de Interiores; 4. Palácio Itamaraty.

\section{ABSTRACT}

This dissertation analyzes the design process of the Itamaraty Palace, in Brasília, between the years 1959 and 1970, from the survey of primary sources, such as projects, photographs, newspapers, magazines, reports in order to make a reading between the documents. The objective is to understand what was desired and conceived at the time of the project's execution. To this end, some issues that involved the project are presented, such as the importance of the transfer of the Ministry of Foreign Affairs for the consolidation of Brasília and the choice of the name for the palace. Finally, it discusses the formation of palace spaces.

KEYWORDS: 1. Modern Architecture; 2. Architectural Design; 3. Interior Architecture; 4. Itamaraty Palace. 
SUMÁRIO 
INTRODUÇÃO 14

1.1. REVISÃO BIBLIOGRÁFICA

17

1.2. APRESENTAÇÃO DOS CAPÍTULOS

20

2 PROCEDIMENTOS METODOLÓGICOS 22

2.1. ARQUIVOS E FONTES 23

2.2. ORGANIZAÇÃO DOS DADOS 29

2.3. VISITASTÉCNICAS 30

2.4. ANÁLISE DOS DADOS 31

3 A FORMAÇÃO DAS PARTES 32

3.1. UM PALÁCIO PARA A CONSOLIDAÇÃO DE BRASÍLIA 33

3.2. UM NOME PARA O PALÁCIO 38

3.3. O CLIENTE 42

3.4. A FORMAÇÃO DAS PERSONAGENS 46

3.5. OS PRIMEIROS PROGRAMAS E PROJETOS PARA O PALÁCIO 64

4 OS ESPAÇOS PALACIANOS 74

4.1. PRIMEIRA APROXIMAÇÃO: IMPLANTAÇÃO E FACHADAS 74

4.2. TÉRREO 100

4.3. SEGUNDO PAVIMENTO 122

4.4. TERCEIRO PAVIMENTO 148

4.5. SUBSOLO 174

5 CONSIDERAÇÕES FINAIS 188

6 REFERÊNCIAS 200 


\section{INTRODUÇÃO}

"Todos os sacrifícios, glórias e picuinhas dos anos incertos da construção do Palácio, toda a febril atividade na conclusão, decoração e ocupação da nova casa, todas as vitórias e derrotas, todos os sonhos e pesadelos, tudo, tudo isso agora é passado, é história. O que parecia um 'sonho, uma alucinação do visionário' Embaixador Murtinho, como dizem alguns de seus colegas, passou a ser uma realidade.” (MENDES, 1995, p. 111)

Os dizeres do jornalista Manuel Mendes ${ }^{1}$ apresentam o ambiente instável e improvável que o Palácio Itamaraty foi gerado. Conjuntas que, evidentemente, desaparecem no espaço construído do "mais belo" palácio de Brasília, como é referido por muitos desde a época de sua construção. Tal ideia é apresentada na matéria "Itamarati, o mais fabuloso palácio moderno do mundo”, do jornalista Duílio de Almeida:

Setenta e dois mil metros quadrados de área construída abrigam o mais fabuloso Palácio moderno de que se tem notícia em todo mundo: O Itamarati. E, de longe, nos apresenta uma impressionante ilusão de um mirificentíssimo gigante de concreto armado flutuando em um lago. ${ }^{2}$

Entre sacrifícios, glórias e divulgações constantes do andamento da obra, o Palácio Itamaraty foi concretizado a partir da agência do Embaixador Wladimir Murtinho. A inquietação que move esta dissertação de mestrado surge da relação entre os dois relatos citados: ao mesmo tempo que é visto como um projeto exemplar da produção moderna no Brasil - pelos especialistas e público em geral - que abarca da arquitetura, com desenhos de Oscar Niemeyer, estrutura de Joaquim Cardoso, o projeto executivo de

$1 \quad$ O jornalista foi responsável pela cobertura dos assuntos ligados ao Ministério das Relações Exteriores pelo jornal Correio Braziliense entre 1964 e 1992. E, assim, acompanhou parte do processo de concepção, construção e ocupação da nova sede do ministério em Brasília. Seus textos sobre este período encontram-se reunidos em O Cerrado de casaca.

2 ALMEIDA, Duílio de. "Itamarati, o mais fabuloso palácio moderno do mundo". Jornal Correio Braziliense, Brasília, 07 de junho de 1967, p. 9. 
Milton Ramos e o paisagismo de Burle Marx, às obras de arte de Bruno Giorgi, Sergio Camargo, Mary Vieira, Athos Bulcão, Alfredo Volpi, Maria Martins, Alfredo Ceschiatti, Pedro Correia de Araújo, José Pedrosa, Luiza Muller, Manabu Mabe, Milton Dacosta, Maria Leontina, Madeleine Colaço, Sônia Ebling, Darel Valença, Fayga Ostrower, Franz Weissmann, Djanira, Iberê Camargo e Cândido Portinari ${ }^{3}$ até o mobiliário moderno de Sergio Rodrigues, Joaquim Tenreiro, Jorge Hue, Bernardo Figueiredo e luminárias de Lívio Levi. É também visto dentro de uma conjuntura político-econômica complexa, pois entre 1960 e 1970, uma série de eventos eclodiram. O Brasil teve 6 presidentes em situações diversas: Juscelino Kubitschek que inaugura Brasília em abril de 1960, Jânio Quadros e sua renúncia, em 1961, João Goulart e o parlamentarismo (1961-1964), um golpe civil-militar ${ }^{4}$, o governo dos generais Humberto Castelo Branco (1964-1967), que despachava, sobretudo, do Palácio das Laranjeiras, no Rio de Janeiro, Artur da Costa e Silva (1967-1969) - que, ao contrário de seu antecessor, despachava de Brasília, uma junta provisória nos finais de 1969 e o governo de Emílio Garrastazu Médici (1969-1974). Embora a inauguração de Brasília seja em abril de 1960, no governo Juscelino Kubitschek, sua consolidação como capital ocorre só em 1970, a contragosto de muitos funcionários públicos, inclusive diplomatas que não desejavam sair da antiga capital, o Rio de Janeiro.

De modo que estudar o Palácio Itamaraty permite diversas entradas e formas de compreensão. É possível pensá-lo a partir das disputas políticas do período, da instabilidade de Brasília e da capacidade do Ministério das Relações Exteriores de agenciar a construção das embaixadas, fato necessário para a consolidação da nova capital. Pode-se entender o uso deste edifício na divulgação de Brasília e do Brasil, em muito pelas fotografias de Marcel Gautherot. Pode-se ver no interior do edifício uma narrativa sobre a identidade brasileira, tema bastante debatido na formação dos projetistas - arquitetos e designers - e artistas dos anos 1960 e 1970 e, sobretudo, na formação do corpo diplomático. Facilmente pode ser pensado como museu ou como uma instituição com um acervo emblemático da cultura brasileira. Também é possível refletir sobre o palácio a partir da comparação com

3 Até a inauguração, também estavam presentes as seguintes peças: aquarela do Rio de Janeiro de Rivière e litografias de vistas do Recife de Emil Bauch e do Rio de Janeiro, de Martinet; tapeçarias persas e de Aubusson; pinturas O grito do Ipiranga, de Pedro Américo, Reconhecimento do Império do Brasil e sua independência (entrega de credenciais do Embaixador Charles Stuart), de Leon Tirode, Retrato de Guedes Pinto, de António Manuel da Fonseca, um retrato de Hipólito José da Costa, autoria descinhecida, Retrato de D. João VI e Retrato de D. Pedro I, de Rodolfo Amoedo, Retrato de D. Pedro II, de Delfim Joaquim Maria Martins da Câmara; mobiliário histórico, como, oratório do século XVI, arcaz, mesa dos tratados e mesa goiana, mesa holandesa, duas cômodas de Maria Cristina e de Dom João VI e cadeira Dom João $\mathrm{V}$, além de escultura e teto pintado de uma capela mineira do século, ambos do século XVIII.

4 Ver NAPOLITANO, Marcos. 1964: História do Regime Militar Brasileiro. São Paulo: Contexto, 2014. 
outros edifícios canônicos na arquitetura moderna no Brasil, como o antigo Ministério da Educação e Saúde (MESP), atual Palácio Capanema. É um edifício institucional que tem seus interiores pensados com muito cuidado por seus idealizadores e foi um campo de possibilidades para os designers brasileiros.

Isto posto, o estudo da concepção e construção do Palácio Itamaraty mostrou-se como um labirinto. Impossível não perceber a densa conjuntura política, social e cultural em que a elaboração deste projeto estava inserida. Este olhar foi possível devido a vasta produção documental que foi levantada pela pesquisa. Além de trabalhos acadêmicos e publicações relacionadas ao tema, há notícias constantes em diversos jornais que apresentavam fatos e o andamento do projeto do palácio. Também há matérias em revistas de arquitetura sobre o projeto. Há cartas trocadas entre os agentes do processo e depoimentos registrados. Existem desenhos e projetos executivos de arquitetura elaborados por Milton Ramos, os projetos de paisagismo de Burle Marx e os projetos dos mobiliários. Há fotografias tiradas por fotógrafos profissionais, como é o caso de Marcel Gautherot e fotografias de registro da obra dos profissionais envolvidos. Há relatórios do Ministério das Relações Exteriores e o Convênio firmado com a Bienal de São Paulo. Existem Projetos de Lei e Requerimentos de Informações sobre a construção do palácio. E, sobretudo, há o próprio palácio. De modo que a existência desses documentos possibilitou a leitura sobre o processo de projeto. Tais documentos enfatizam a complexidade do fazer arquitetura.

Assim, esta dissertação apresenta e interpreta a produção do espaço do edifício representativo do Ministério das Relações Exteriores - o Palácio Itamaraty - entre 1959, ano em que se começa a esboçar o projeto, até 1970, data da inauguração do palácio. O espaço produzido é resultado da relação entre arquitetura, paisagismo, obras de arte e mobiliário. Porém, há diversos tempos na formação deste palácio. Alguns objetos foram incorporados a esta espacialidade posteriormente e, também, há objetos que foram alterados de lugar. No texto que se segue, não há o desejo de que o palácio retorne ao que foi pensado originalmente, já que é entendido que o tempo e novos agentes surgem no processo de uso dos ambientes construídos.

No entanto, o objetivo deste trabalho é compreender o que era desejado e concebido à época da execução do projeto, pois a partir do promenade architecturale pelo palácio é possível ter leituras estéticas sobre o espaço, além da narrativa de um Brasil. O não levantamento de documentos históricos do período pode levar a leituras anacrônicas acerca deste palácio, já que houve mobilidade entre os objetos e acréscimo de outros. Para isso, levantou-se diversas fontes primárias - projetos, fotografias, jornais, revistas, relatos e relatórios - realizando uma leitura cruzada entre as fontes. 


\title{
1.1. REVISÃO BIBLIOGRÁFICA
}

A ideia de palácio como casa dos reis e dos príncipes surge com as sociedades de cortes europeias dos séculos XVII e XVIII, sendo a França de Louis XIV e o palácio de Versailles, os exemplos mais bem acabados. Norbert Elias, em $A$ sociedade de cortes, já atenta para a importância destes ambientes na estrutura social:

\begin{abstract}
A todas as reuniões de seres humanos corresponde uma certa organização do espaço que lhes permite organizaremse na totalidade ou por unidades parcelares. Por esse motivo, o reflexo de uma sociedade no espaço, o tipo de organização espacial que adopta, representa de uma maneira concreta, no sentido mais rigoroso do termo, as suas características particulares. (ELIAS, 1987, p. 20)
\end{abstract}

No entanto, os palácios de Brasília estão em outro contexto histórico. As edificações foram construídas em um governo democrático e igualitário, com características de uma marca ou identidade brasileira, como certo despojamento, originalidade e leveza. Tais edifícios carregam questões simbólicas, de rituais políticos e um programa arquitetônico. Nos palácios modernos, porém, a suntuosidade e o luxo dão lugar à interiores funcionais com elementos visuais construtivos, em que a relação com o vazio é parte desta espacialidade. Em ambos os casos, não houve a apropriação de palácios já construídos, mas sim a elaboração e a construção destes edifícios.

No Brasil, a produção destes palácios apresentou possibilidades de experimentação para a prática projetual. Sobretudo, mas não só, no desenvolvimento de uma produção com início no Rio de Janeiro, a Escola Carioca, que teve em Brasília o auge de sua produção, em que havia um diálogo constante e intrínseco entre arte, arquitetura e design:

Os palácios, pela peculiaridade de suas condições de funcionamento, ofereceram uma plataforma de experimentações em seus interiores, em projetos integrados com as artes e arquitetura. Isso ocorreu, primeiramente de forma tímida, contrastando com a própria monumentalidade dos edifícios, como nas áreas de recepção do Palácio do Planalto e Palácio da Alvorada, de peças de mobiliário de diferentes épocas e linguagens - ecléticas, barrocas - convivem com unidades de desenho internacional moderno e peças brasileiras existentes no 
mercado naquele momento. (SANTOS e SAKURAI, 2017, p. 32)

A arquitetura moderna no Brasil participa das questões enfrentadas pela arquitetura moderna, como a industrialização e o processo de produção em uma sociedade de massa, isto é, para o usuário anônimo. Na linguagem arquitetônica, a oposição era clara aos estilos históricos que lastreavam os edifícios de caráter oficial e utilizavam a tipologia histórica e volumétrica. Em contrapartida, nomes como Le Corbusier, Walter Gropius e Mies van der Rohe construíram um novo vocabulário formal. Le Corbusier inventou um dispositivo urbano, o piloti, em que arquitetura e urbanismo tornaramse elemento único, além de permitir espaços mais fluidos com o uso da planta livre. Walter Gropius foi responsável pela criação de uma escola experimental, a Bauhaus, que assimilou a indústria e dissipou a ideia da série - do objeto ao urbanismo. Mies van der Rohe criou a arquitetura com planos ortogonais e visualmente infinita. Todos acreditavam no caráter comunicativo e formador da arquitetura.

No Brasil, a arquitetura moderna assumiu uma expressão nativa que, segundo Luiz Antônio Recamán Barros "liberou nossa autoconsciência a ponto de nos impor a criação de um modernismo próprio, que de certa forma nega o moderno como fenômeno universal, em sua ocorrência sempre nacional" (BARROS, 1996, p. 37). Brasília é o ápice e marca o esgotamento da vertente hegemônica da arquitetura moderna no Brasil, a Escola Carioca. Para além disso, possibilita a compreensão da estética moderna brasileira, como apontou Ronaldo Brito, em seu artigo sobre Lúcio Costa, já que é a síntese histórica entre o Estado patriarcal e uma vanguarda estética que teve base institucional para materializar o seu projeto estético (CONDURU, NOBRE, et al., 2004, p. 245).

No campo do entendimento da formação e consolidação da arquitetura moderna no Brasil, a dissertação Por uma arquitetura, brasileira bem como a tese Oscar Niemeyer: forma arquitetônica e cidade no Brasil moderno, de Luiz Antônio Recamán Barros defendem que a arquitetura moderna no Brasil é fruto de um projeto estatal, tal ideia também é sustentada por Carlos Alberto Ferreira Martins em sua dissertação Arquitetura e Estado no Brasil. Elementos para uma análise da constituição do discurso moderno no Brasil. A obra de Lucio Costa 1924-52. Heloísa Espada estudou o fotógrafo Marcel Gautherot em seu doutorado, cuja tese Monumento e Sombra na Brasília de Marcel Gautherot apresenta Brasília como uma cidade que foi construída para ser fotografada e publicizada. Tais leituras indicam uma produção arquitetônica que tem como características a formação e a divulgação de uma ideia de Brasil. O Palácio Itamaraty, sede do Ministério das Relações Exteriores, tem como um de seus programas ser o cartão de visitas do Brasil. Portanto, um edifício com fins políticos e mais do que qualquer outro deseja 
expressar uma narrativa de brasilidade. Curiosamente, percebemos durante o levantamento bibliográfico que este palácio fica a margem dos estudos sobre Oscar Niemeyer e Brasília.

O Ministério das Relações Exteriores pertence ao grupo institucional de ministérios e, portanto, deveria ter o mesmo desenho dos demais ministérios, alinhado perpendicularmente ao Eixo Monumental. Ou seja, a mesma solução formal indicaria edifícios com o mesmo significado e uso no plano urbano de Brasília. No entanto, tal tipologia formal, como bem notou Bruand, não ocorre:

Originalmente, o plano de Lúcio Costa previa que todos os ministérios seriam idênticos; ora, os responsáveis pela diplomacia brasileira não aceitaram o edifício padrão proposto e observaram, com razão, que eles não podiam contentar-se com o bloco destinado aos serviços administrativos. (BRUAND, 1999, p. 197)

Para o Ministério da Justiça e o Ministério das Relações Exteriores foram projetados edifícios com um desenho específico, que difere de um ministériotipo. Além de suas atividades específicas, essa diferença provoca uma sutil passagem entre a Praça dos Três Poderes e a Esplanada dos Ministérios.

De modo geral, o Palácio Itamaraty é apresentado nos estudos sobre a obra de Oscar Niemeyer como uma das obras mais belas do arquiteto. Yves Bruand, o primeiro a fazer uma monografia sobre a arquitetura moderna no Brasil, foi o que mais apresentou informações sobre o projeto do palácio "mais belo de Brasília". Gilbert Luigi em Oscar Niemeyer une esthétique de la fluidité aponta para a horizontalidade de um dos palácios mais prestigiados, bem como para a repetição as arcadas clássicas, mas com um jardim aquático. Em Oscar Niemeyer and the Architecture of Brazil, David Underwood compara o mais clássico de todos os palácios com a arquitetura romana e de Chandigarh, de Le Corbusier, pela presença do concreto bruto ocre. Styliane Philippou descreve o palácio como calmo e elegante em Oscar Niemeyer: Curves of irreverence.

Desde seu doutorado, Eduardo Rossetti reflete sobre o Palácio Itamaraty, analisando-o em perspectiva com o SESC Pompéia, de Lina Bo Bardi, e a Faculdade de Arquitetura e Urbanismo da USP, de Vilanova Artigas. Em seu artigo Palácio do Itamaraty: questões de história, projeto e documentação (1959-70), apresenta diversas fontes que podem ser utilizadas para a compreensão do projeto, tais como croquis, fotografias, discursos, jornais, entrevistas, relatos orais e ofícios. A publicação Palácio Itamaraty: A arquitetura da diplomacia, integrante da Coleção Memória da Caixa Econômica Federal, contém textos de Eduardo Rossetti e Graça Ramos, além de fotografias de Graça Seligman. Eduardo Rossetti descreve a 
transferência de sede, apresenta o caráter simbólico deste edifício, defende a autoria do projeto como de Oscar Niemeyer; aponta a importância da antiga sede da chancelaria no Rio de Janeiro e da arquitetura clássica para o desenvolvimento do projeto. Também enfatiza a integração entre as obras, da caixilharia, da paginação, dos painéis e do paisagismo. Por sua vez, Graça Ramos apresenta a importância do Embaixador Wladimir Murtinho para a construção do palácio e conta a história da aquisição de algumas obras de arte. Reflete como as obras são representativas do ideal do Brasil moderno a partir da formação da coleção deste palácio-museu.

Na questão formal, Sophia Telles é fundamental para a compreensão do processo de Oscar Niemeyer: são desenhos planos transpostos para o espaço, em que o vazio e a linha do horizonte são fundamentais para a apreensão da obra. Nos estudos de Marco do Valle, a solução formal de Niemeyer no palácio juntamente com o Palácio da Justiça e a sede da Mondadori permanece isolada no processo projetual do arquiteto. E, também para o próprio arquiteto, o projeto permanece isolado: "somente no Ministério do Exterior agi diferente, desejoso de demonstrar como é fácil agradar a todos com uma solução correta, generosa, mas corriqueira, dispensando maior compreensão e sensibilidade". (NIEMEYER, 1998, p. 273)

Nos dois volumes do Relatório de Pesquisa em Pós-Doutorado na FAUUSP de Guilherme Mazza Dourado, Folhas em movimento - cartas de Burle Marx - e Folhas de toda a parte - cartas para Burle Marx, há a transcrição das cartas do paisagista. A partir da leitura das cartas que citam o projeto de paisagismo e a tapeçaria, podemos observar o desenvolvimento do projeto de paisagismo.

\subsection{APRESENTAÇÃO DOS CAPÍTULOS}

O volume da dissertação estrutura-se em 3 capítulos que refletem sobre o procedimento de projeto no Palácio Itamaraty. No primeiro capítulo, Procedimentos metodológicos: o processo de projeto a partir da documentação histórica, apresentam-se os procedimentos metodológicos, discutindo as fontes primárias encontradas ao longo da pesquisa e os arquivos consultados. Demonstra-se assim o caminho para a construção da metodologia que tornou possível o cruzamento de diversas fontes primárias para a leitura dos processos e, posteriormente, dos espaços do palácio.

O segundo capítulo, A formação das partes, apresenta a discussão sobre as conjunturas e as questões que envolveram o projeto, como a narrativa da importância da transferência de sede do Ministério das Relações Exteriores - do Rio de Janeiro para Brasília - como forma de consolidação da nova capital. Também é apresentada a variedade de nomes que foram pensados 
1. INTRODUÇÃO / 21

para o palácio. Faz-se uma breve reflexão sobre a formação do solicitante do projeto, o Ministério das Relações Exteriores, e sua relação com a divulgação da produção cultural do Brasil para o estrangeiro. Apresenta-se os sujeitos responsáveis pela elaboração das peças e dos espaços do palácio. E, por fim, mostra o desenvolvimento dos projetos iniciais para o palácio.

Os espaços palacianos, o terceiro capítulo, é dividido em cinco partes: implantação e fachada, térreo, segundo pavimento, terceiro pavimento e subsolo. O capítulo é apresentado a partir do promenade architecturale sugerido pelo edifício, mostrando as mudanças nestes ambientes durante a elaboração dos projetos a partir da leitura cruzada entres as fontes primárias, em que se discute as escolhas e transformações no projeto até que se chegasse ao espaço construído.

E, por fim, na conclusão, discute-se os resultados obtidos pela pesquisa apresentados na dissertação, indicando lacunas e possíveis caminhos para pesquisas futuras. 


\title{
PROCEDIMENTOS METODOLÓGICOS
}

\author{
O PROCESSO DE PROJETO A PARTIR DA \\ DOCUMENTAÇÃO HISTÓRICA
}

Ao percorrer o Palácio Itamaraty, o visitante pouco apreende sobre as camadas de decisões envolvidas nos onze anos entre sua concepção e construção. Tudo parece finalizado e estático. No entanto, basta pensar nas querelas sobre os processos atuais de conservação dos palácios que esta solidez se desmancha. Uma edificação não está imune ao tempo - seja pelo desgaste da própria materialidade, seja pela mudança nas necessidades do programa.

O caminhar pelos espaços internos é parte do programa do cerimonial do Palácio Itamaraty. Quem por arcadas, jardins, obras de arte e mobiliário passa facilmente é seduzido pelo palácio que nos leva a acreditar que os objetos sempre estiveram assim posicionados. Mas não é bem assim. Algumas peças mudaram de localização e novas demandas surgiram para o uso do espaço. Ademais, nem mesmo o Embaixador Wladimir Murtinho ficou no cargo de presidente da Comissão de Transferência até o término da obra.

As peças que estão no palácio foram adquiridas da forma mais plural. Algumas foram especificadas por Oscar Niemeyer, outras solicitadas por Wladimir Murtinho. Algumas foram doações, outras compradas. Há também as que vieram da antiga sede carioca. Existem peças que foram adequações de projetos executados anteriormente, outras foram desenvolvidas especialmente para o palácio.

Para lidar com essa diversidade de eventos, agentes e obras que cobrem a produção deste palácio, de 1959 a 1970, esta pesquisa de mestrado adota a abordagem qualitativa, de natureza compreensiva, a partir de pesquisa bibliográfica e documental, com a sistematização das informações por meio de planilhas eletrônicas e análises visuais.

O método de pesquisa considera a relação entre várias perspectivas na leitura do projeto de arquitetura, o que justifica a mobilização de fontes documentais de natureza diversa para a compreensão do objeto, pois parte do pressuposto que a edificação está em diálogo com as demais conjunturas do momento, tais como social, política e cultural. O estudo cruza os dados encontrados na bibliografia, em revistas de arquitetura de época, documentos históricos, depoimentos e projetos, para verificar e compreender as questões enfrentadas pela equipe de projeto do palácio à época da construção questões estas que não são claras na experiência espacial do edifício. 


\subsection{ARQUIVOS E FONTES}

O levantamento de informações sobre o Palácio Itamaraty em projetos, cartas, fotografias, relatos, relatório, memorial, jornais e revistas ocorreu em arquivos públicos e privados, a partir de consultas física e digital. A bibliografia sobre o palácio também foi levantada e está apresentada na Introdução desta dissertação.

Para buscar os fatos e as conjunturas do processo de projetar, levantouse os documentos primários, como relatos e desenhos. Neste momento, percebeu-se que as atividades de conceber, projetar e construir o palácio envolveram diversos profissionais que foram fundamentais para a concretização do edifício tal como conhecemos. A partir do conhecimento prévio de diversos agentes que participaram do processo, realizou-se uma relação de possíveis arquivos que tivessem documentação relacionada ao projeto ou ao agente envolvido. O levantamento desejava apresentar profissionais que participaram, mas que não eram óbvios. Era uma maneira de refletir sobre a pesquisa em documentos na pesquisa em projeto de arquitetura a partir da questão de que a leitura de tais documentos pode auxiliar na compreensão das formas construídas e de questões do projeto que não aparecem na edificação. Ademais, o levantamento nos arquivos, de início, buscou ser o da descoberta. Não pesquisar apenas em arquivos que possuem informações sobre o palácio, como os arquivos do Ministério das Relações Exteriores.

As visitas aos arquivos aconteceram de março de 2018 até janeiro de 2020, com agendamento prévio a partir de contato via e-mail ou telefone. $\mathrm{O}$ acesso ao material aconteceu de forma presencial ou digital e, sempre que possível, foi realizado um registro fotográfico pessoal da documentação ou, quando necessário, a transcrição do documento. A documentação foi levantada nos seguintes acervos: 


\begin{tabular}{|c|c|c|c|}
\hline 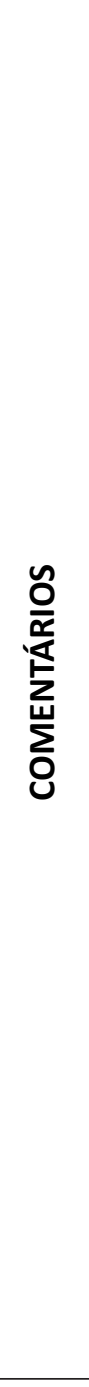 & 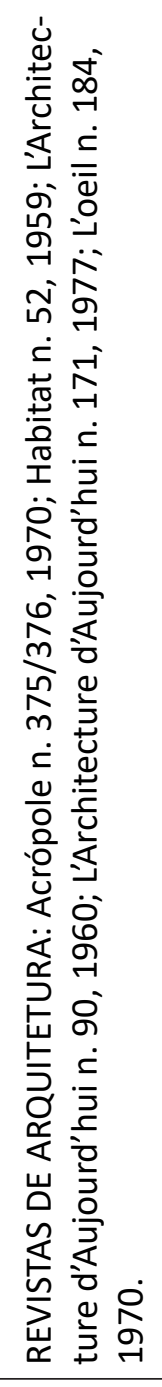 & 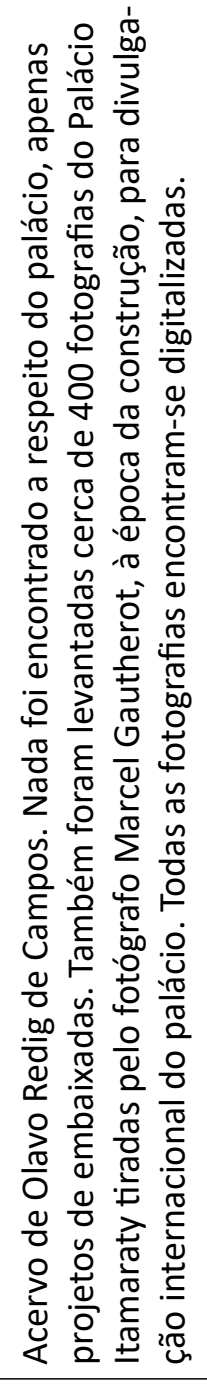 & 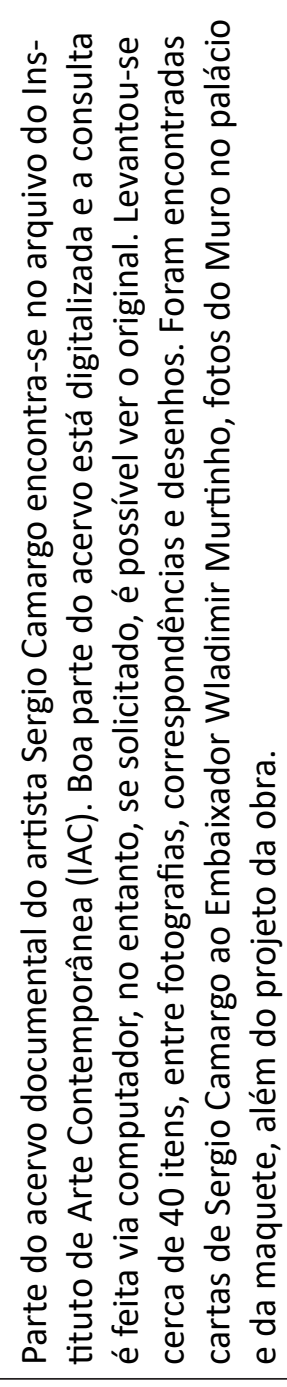 \\
\hline 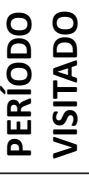 & 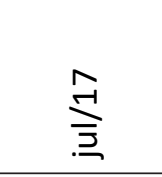 & 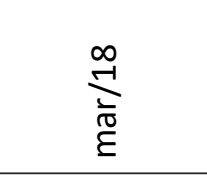 & 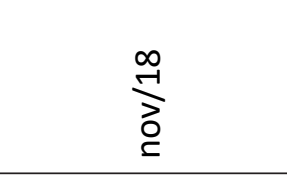 \\
\hline 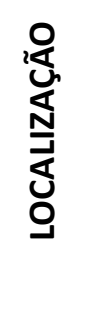 & $\begin{array}{l}\frac{0}{7} \\
\frac{\pi}{0} \\
20 \\
2 \pi 0 \\
n\end{array}$ & $\begin{array}{l}\frac{0}{0} \\
\frac{0}{0} \\
\frac{\pi}{0} \\
\frac{0}{0} \\
\frac{0}{x}\end{array}$ & $\begin{array}{l}\frac{0}{3} \\
\frac{\pi}{0} \\
0 \\
2 \pi 0 \\
\sim\end{array}$ \\
\hline 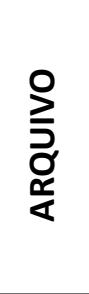 & 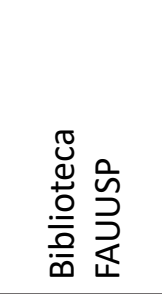 & 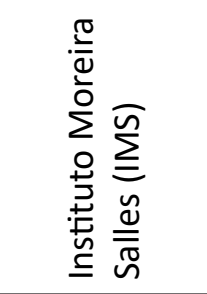 & 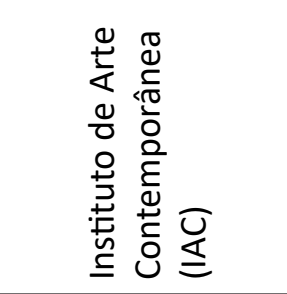 \\
\hline
\end{tabular}




\begin{tabular}{|c|c|c|c|}
\hline 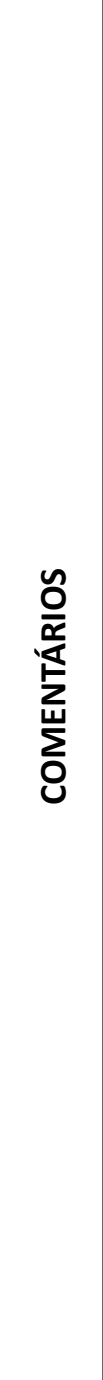 & 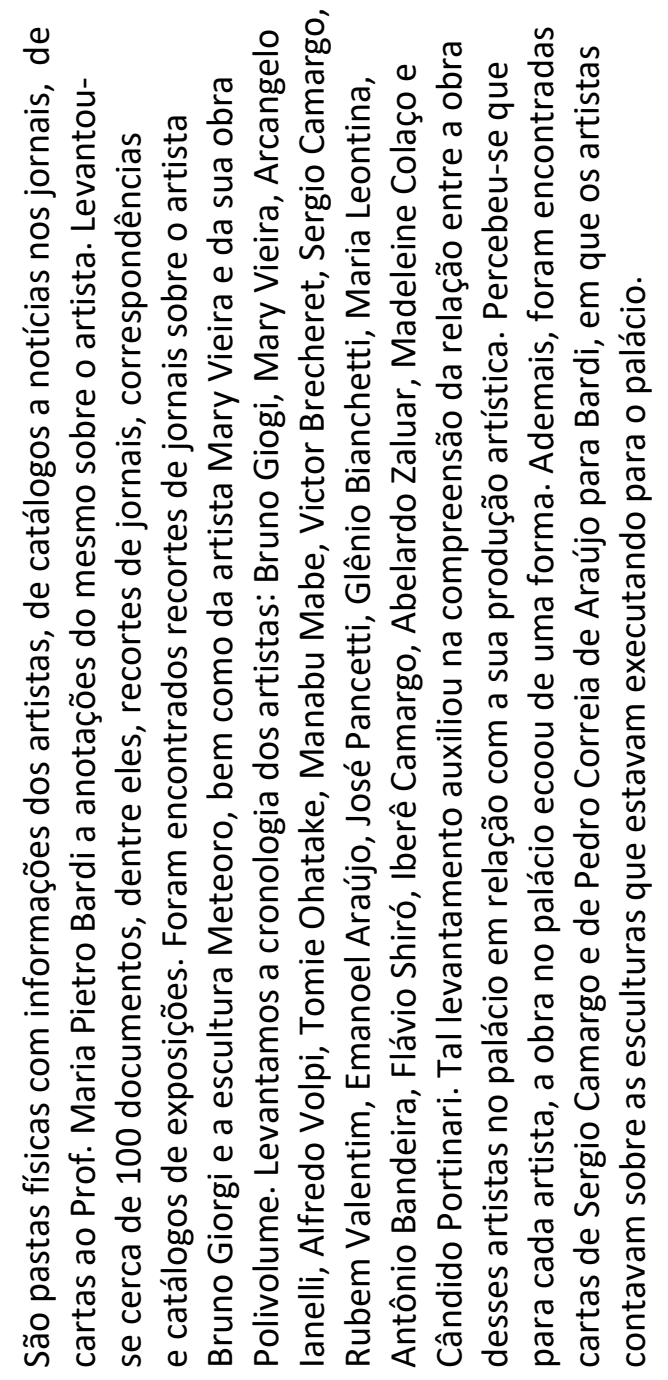 & 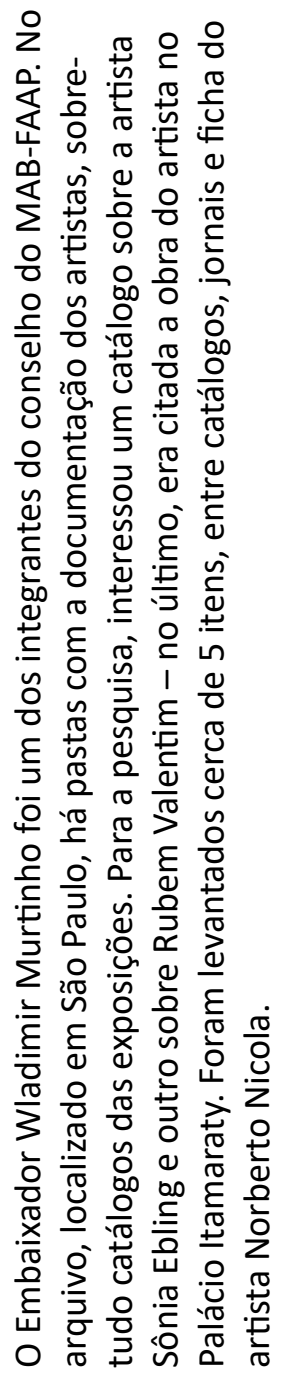 & 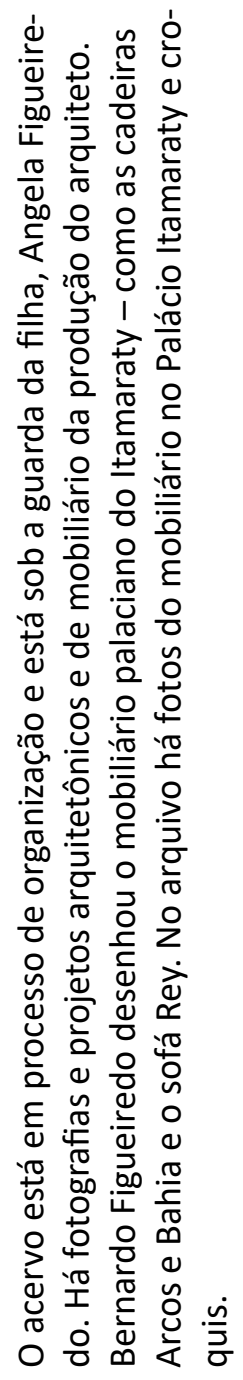 \\
\hline 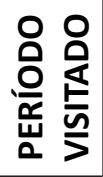 & 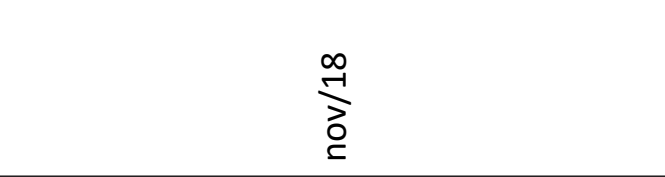 & 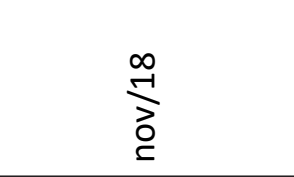 & $\underset{\frac{\mathbb{N}}{0}}{\stackrel{\infty}{\mathbb{N}}}$ \\
\hline 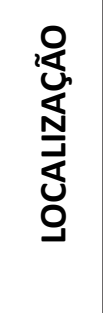 & $\begin{array}{l}\frac{0}{7} \\
\sqrt[\pi]{0} \\
0 \\
2 \pi \\
\sim\end{array}$ & $\begin{array}{l}\frac{0}{7} \\
\sqrt{0} \\
0 \\
0 \\
2 \pi \\
\sim\end{array}$ & $\begin{array}{l}\frac{0}{7} \\
\frac{\pi}{0} \\
00 \\
2 \pi 0 \\
\sim\end{array}$ \\
\hline 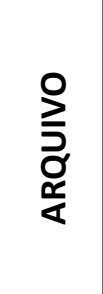 & 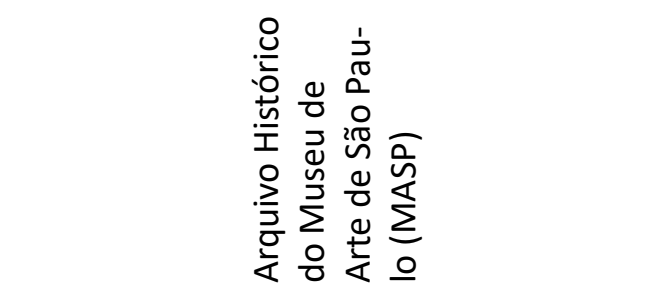 & 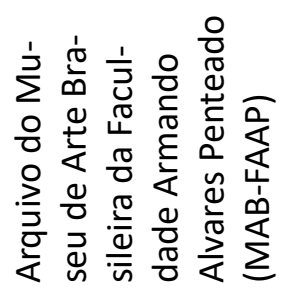 & 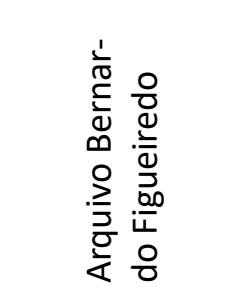 \\
\hline
\end{tabular}




\begin{tabular}{|c|c|c|c|}
\hline 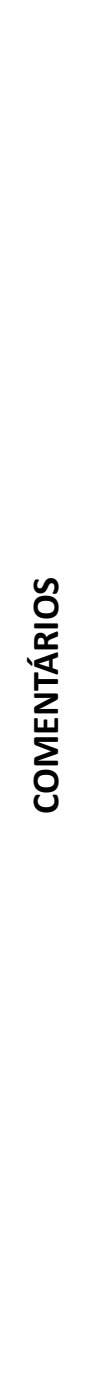 & 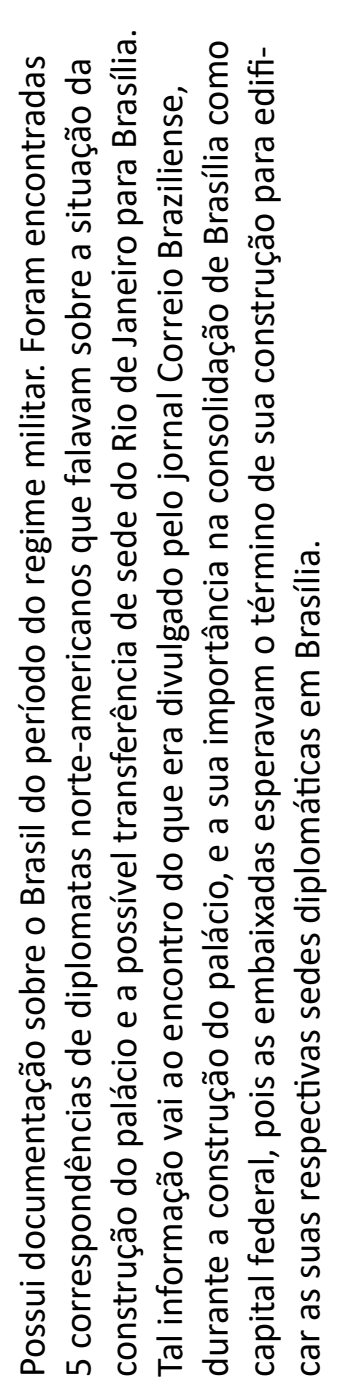 & 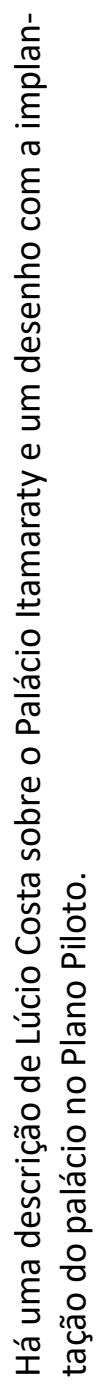 & 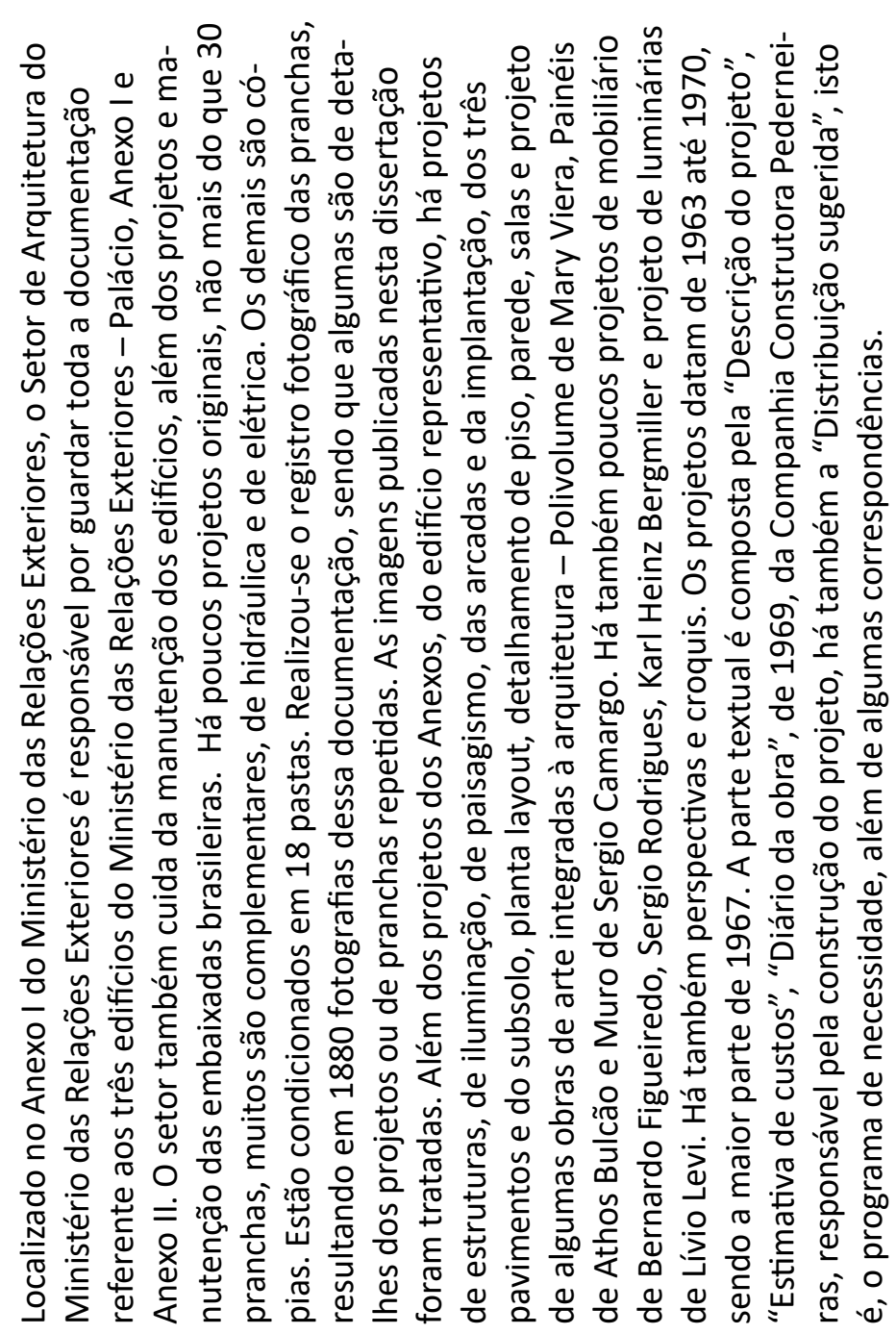 \\
\hline $\begin{array}{l}\text { 응 } \\
\text { 음 } \\
\text { 舀 } \\
\frac{1}{y}\end{array}$ & $\stackrel{\infty}{\vec{J}}_{0}^{\infty}$ & $\frac{\underset{N}{\stackrel{N}{d}}}{\frac{d}{0}}$ & 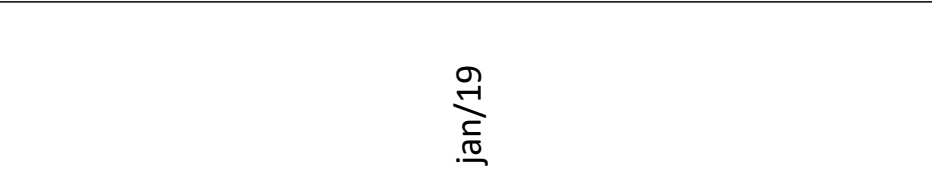 \\
\hline 迹 & 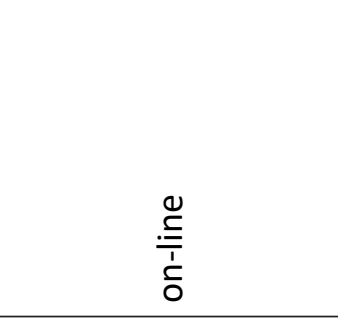 & 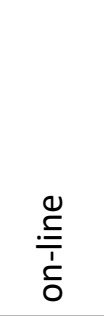 & 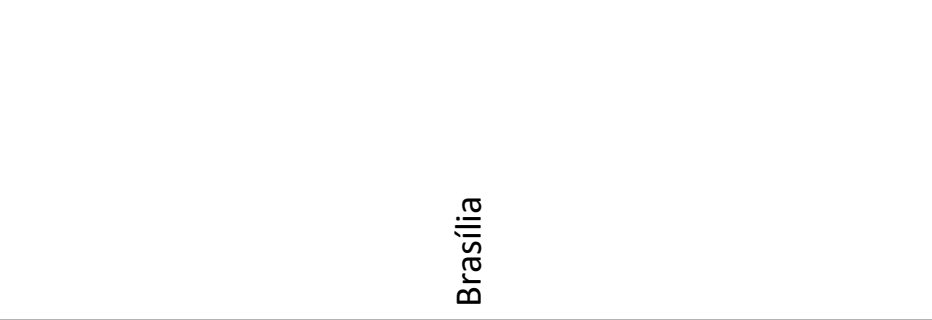 \\
\hline 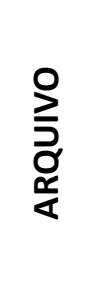 & 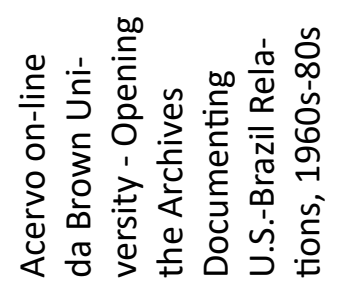 & 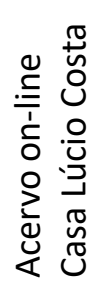 & 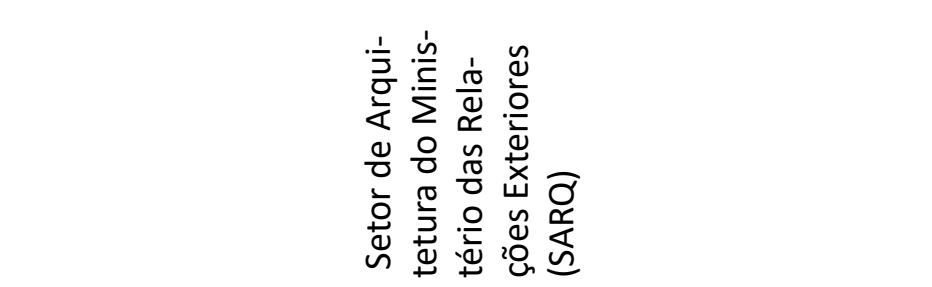 \\
\hline
\end{tabular}




\begin{tabular}{|c|c|c|c|}
\hline 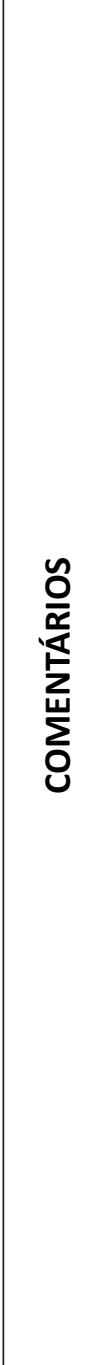 & 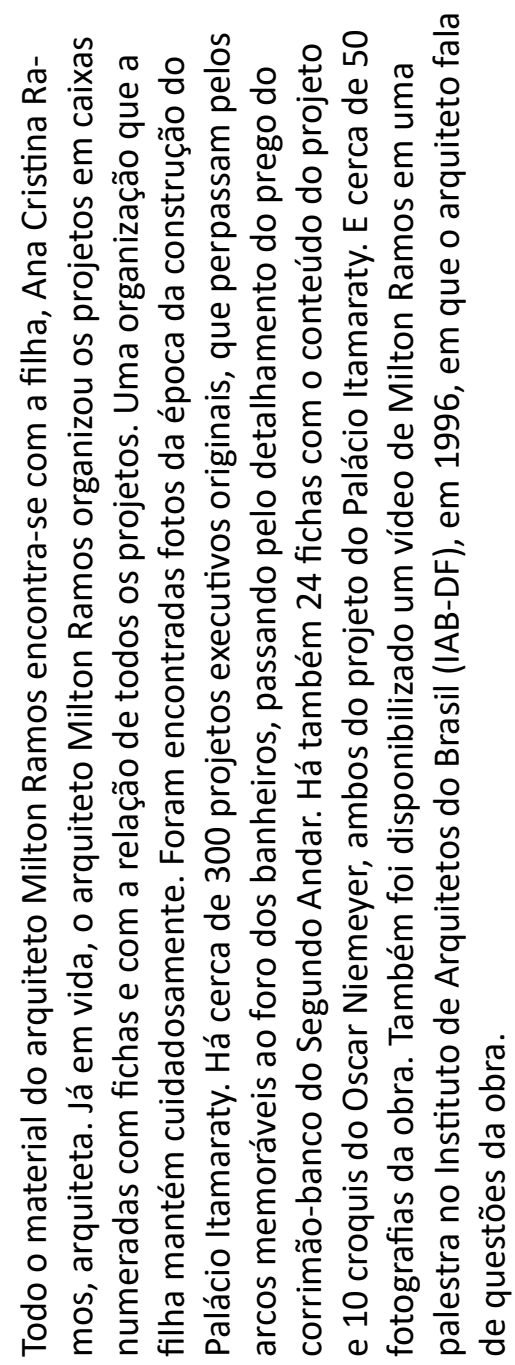 & 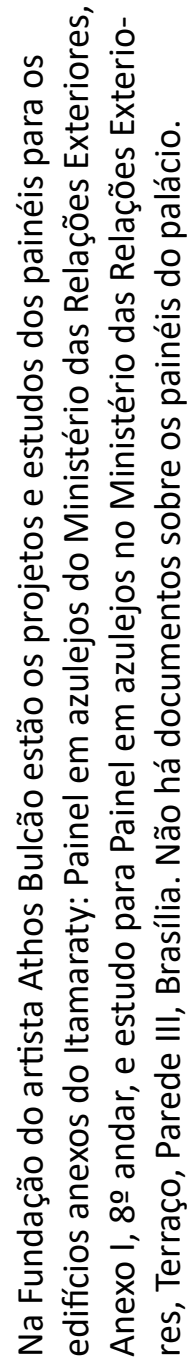 & 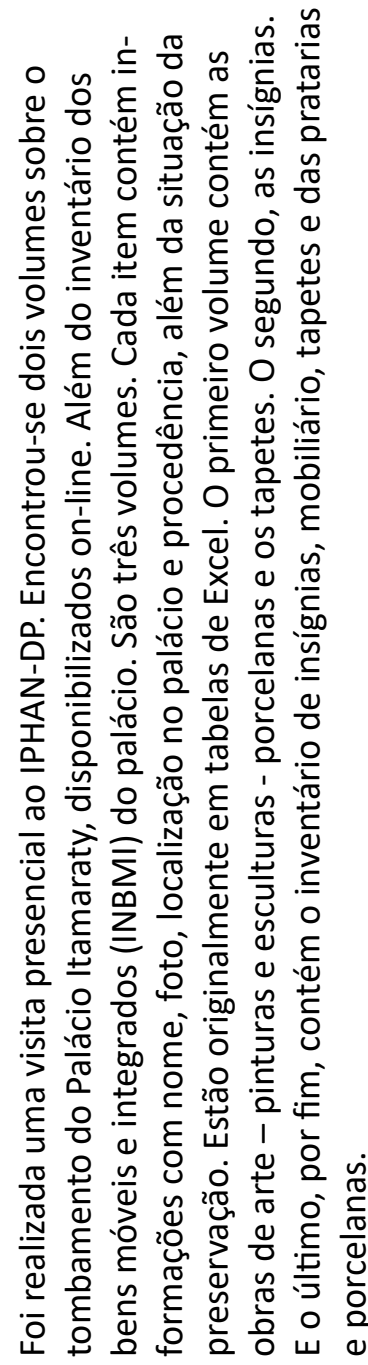 \\
\hline 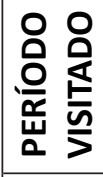 & 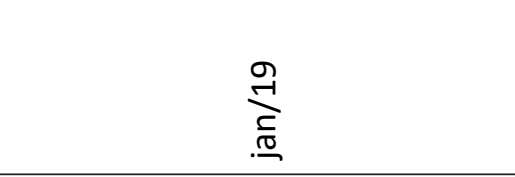 & $\underset{. \stackrel{ }{(0)}}{\stackrel{9}{7}}$ & 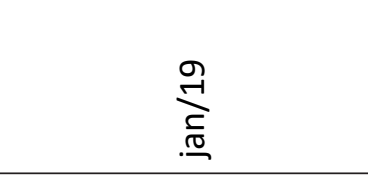 \\
\hline 迩 & $\begin{array}{l}\stackrel{0}{\overline{\overline{5}}} \\
\frac{0}{0} \\
0\end{array}$ & $\begin{array}{l}\stackrel{0}{\overline{\bar{n}}} \\
\frac{0}{0} \\
\stackrel{0}{0}\end{array}$ & 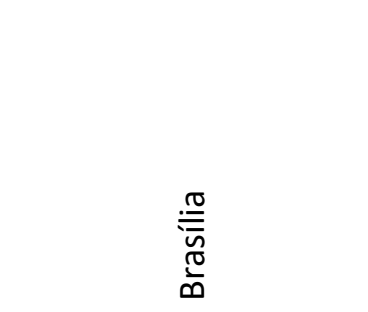 \\
\hline 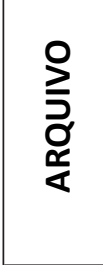 & 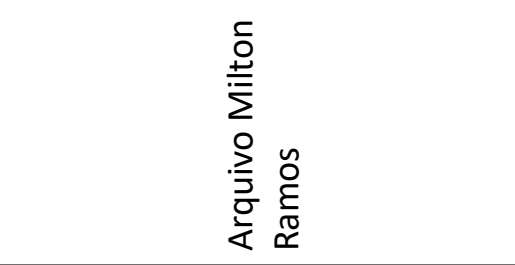 & 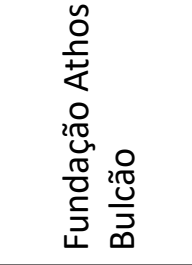 & 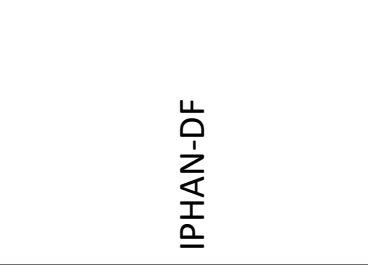 \\
\hline
\end{tabular}




\begin{tabular}{|c|c|c|c|c|c|c|c|}
\hline 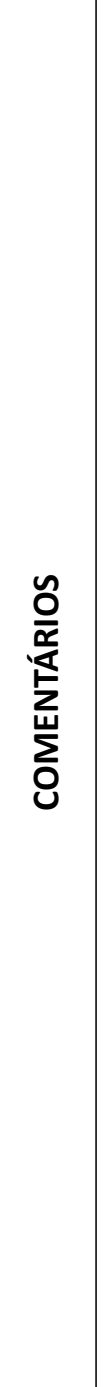 & 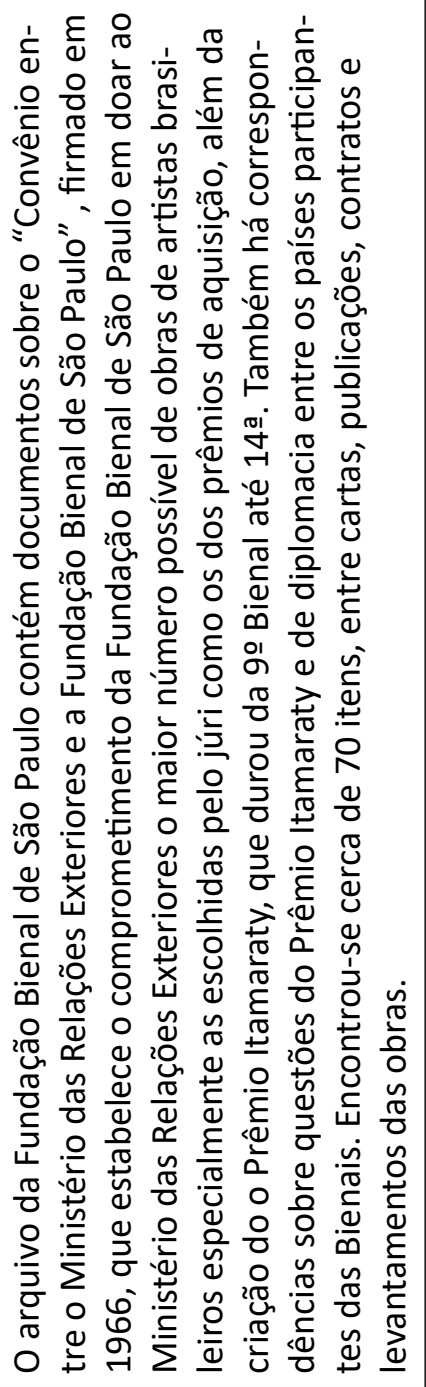 & 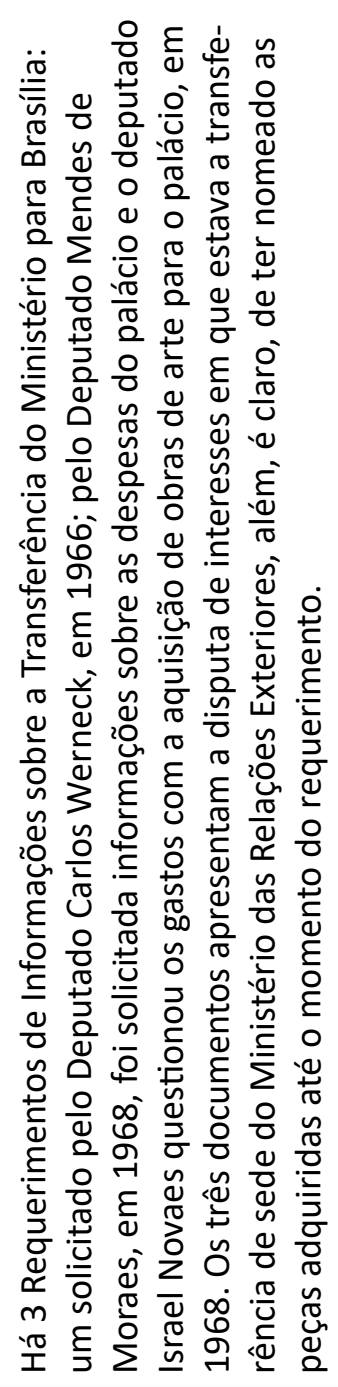 & 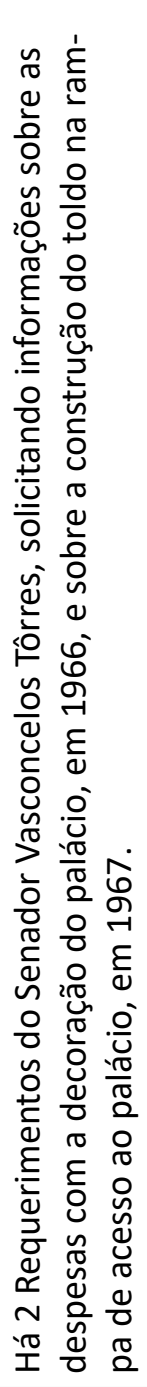 & 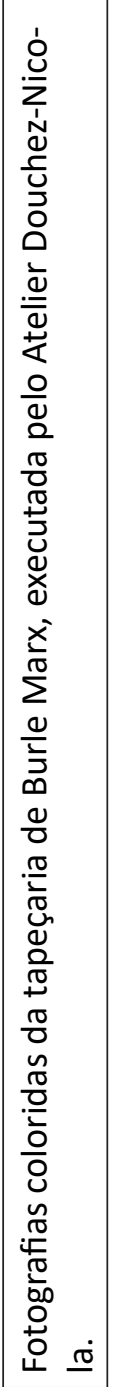 & 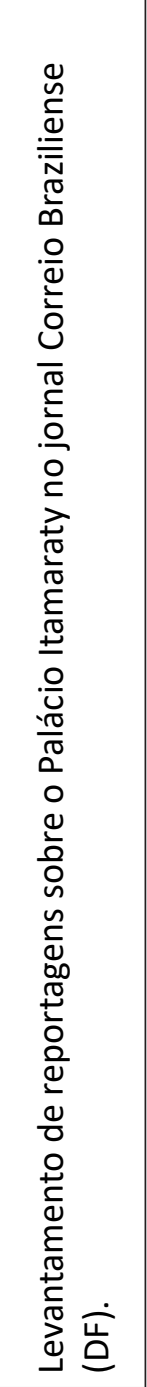 & 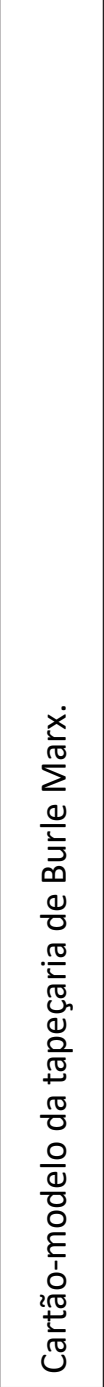 & 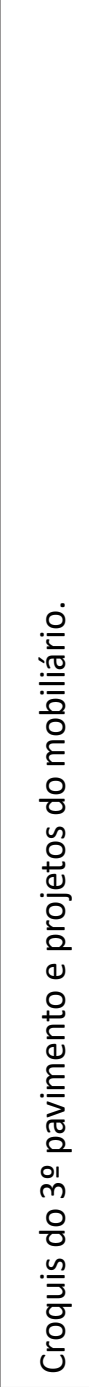 \\
\hline 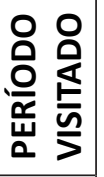 & 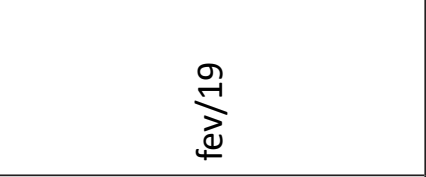 & 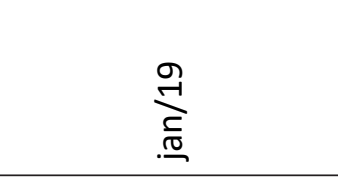 & $\underset{. \stackrel{ }{.0}}{\stackrel{9}{7}}$ & 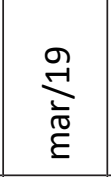 & 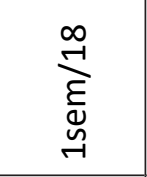 & 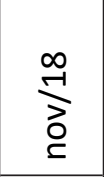 & 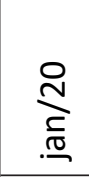 \\
\hline 迩 & $\begin{array}{l}\frac{0}{7} \\
\pi \\
0 \\
0 \\
2 \pi \\
\sim\end{array}$ & 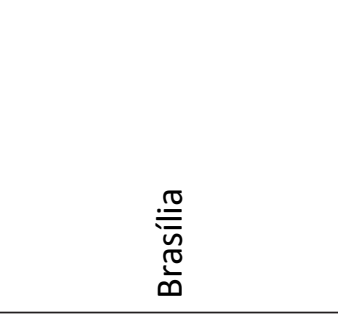 & 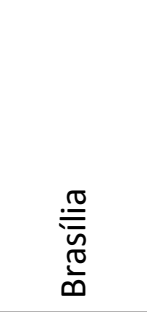 & $\begin{array}{l}\frac{0}{3} \\
\frac{\pi}{0} \\
20 \\
200 \\
\sim 0\end{array}$ & 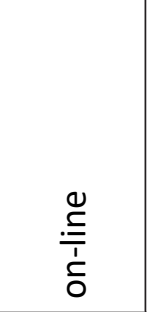 & $\begin{array}{l}\frac{0}{7} \\
\frac{\pi}{2} \\
0 \\
2 \pi \\
\sim\end{array}$ & $\begin{array}{l}\frac{0}{\frac{0}{0}} \\
\frac{\pi}{0} \\
\frac{0}{0} \\
\frac{0}{0} \\
\frac{0}{x}\end{array}$ \\
\hline 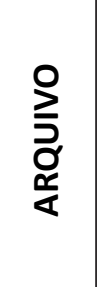 & 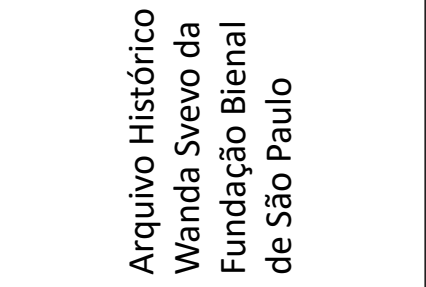 & 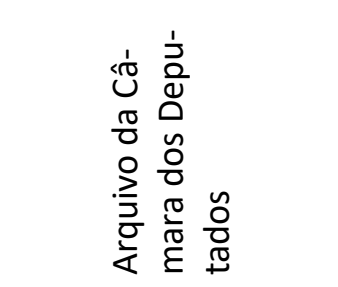 & 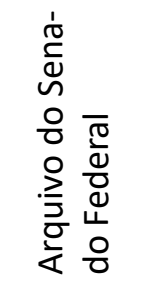 & 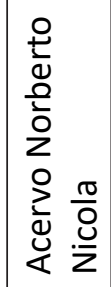 & 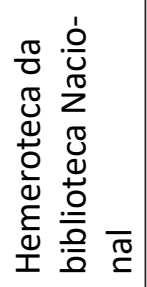 & 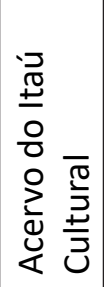 & 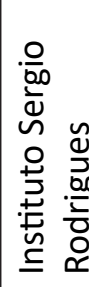 \\
\hline
\end{tabular}


Não foi possível acessar o Arquivo Público do Distrito Federal, pois estava fechado para visitações no período proposto. A documentação do Joaquim Tenreiro pertencente ao Museu de Arte Moderna do Rio de Janeiro (MAMRJ) está em processo de organização.

A documentação histórica de tipologia plural encontrada em arquivos diversos possibilitou a verificação das complexidades do processo de projeto e o lugar do solicitante. Pela pesquisa e acesso aos documentos é possível valorizar e conservar este tipo de material, além disso, a partir das informações encontradas, foi possível refletir sobre outras questões não colocadas e a compreensão da seleção das obras pertencentes ao palácio, percebendo as temporalidades envolvidas no projeto. E o mais importante: tornar pública a existência deste material é uma forma de fazer plural o debate sobre o Palácio Itamaraty, proporcionado ao leitor uma variedade de interpretações. E, longe de se desejar buscar a totalidade de documentos sobre o palácio ou a reconstrução de um evento pretérito, buscou-se vestígios desse processo.

\subsection{ORGANIZAÇÃO DOS DADOS}

Para uma melhor compreensão do material coletado, elaborou-se tabelas em planilhas eletrônicas dinâmicas utilizando-se do software Excel do Pacote Office da Microsoft para sistematização e análise preliminar. Assim é possível catalogar o corpus documental, organizar o material coletado por tipologia, bem como verificar recorrência de temas e lacunas. As tabelas são ferramentas para a análise dos dados e foram criados campos a partir das necessidades da pesquisa. Entre novembro de 2018 e agosto de 2019, elaborou-se as seguintes tabelas:

\subsubsection{Cronologia}

Do projeto dos ministérios, em 1959, à inauguração do palácio em 1970, passaram-se 11 anos. Para não nos perdemos temporalmente, foi elaborada uma cronologia que abarca os eventos da concepção, da construção e da inauguração. Boa parte do material foi retirado do jornal Correio Braziliense e do livro O Cerrado de Casaca, do jornalista Manuel Mendes.

\subsubsection{Levantamento da equipe}

Elaborou-se uma tabela composta pelos campos: nome do profissional Embaixadores, arquitetos, designers, paisagistas e artistas - e dados como 
função no projeto, nascimento-morte, nacionalidade, formação, produção, quantidade de obras no palácio, técnica e material da obra, localização do acervo, referências e observações. Para que fosse possível compreender a atuação do profissional no projeto e a relação com a equipe de projeto.

\subsubsection{Levantamento dos gastos}

A partir do relatório do Embaixador Wladimir Murtinho "Despesas realizadas até a presente data na construção em resposta ao Requerimento de Informações $\mathrm{n}^{0} 4308$ de 1968, pelo deputado Mendes de Moraes” elaborou-se uma tabela com as peças compradas para o novo palácio com o seu valor monetário, o ano da compra e o descritivo.

\subsubsection{Inventário}

A partir do relatório do Embaixador Wladimir Murtinho "Despesas realizadas até a presente data na construção em resposta ao Requerimento de Informações $n^{0} 4308$ de 1968, pelo deputado Mendes de Moraes" foi realizado um inventário com título da obra e foto, autoria, valor, tipologia, dimensões, material, técnica, ano, versão, fabricante, localização no palácio, proveniência, quantidade adquirida e atual, além da documentação. $O$ objetivo desta tabela é comparar o que foi solicitado no projeto com o que está atualmente no palácio.

\subsubsection{Levantamento da documentação}

Para organizar todo o material coletado, criou-se uma tabela com a documentação. Contém os seguintes campos: código de referência, título, autor, formato digital, dia, mês, ano, fundo, tipologia, referente, anotações, imagens e transcrição. A tabela auxiliou no cruzamento de dados e na seleção do material, com uso de tabela dinâmica.

\subsection{VISITAS TÉCNICAS}

Foram realizadas visitas presenciais e com documentação fotográfica do Palácio Itamaraty, no Rio de Janeiro, e do Palácio Itamaraty, em Brasília. Além disso, também foram visitadas outras instituições e coleções com obras de arte de alguns artistas, como o Parque Ibirapuera e Museu Brasileiro da Escultura e Ecologia (MuBE). 


\subsection{ANÁLISE DOS DADOS}

A leitura do projeto do Palácio Itamaraty foi realizada a partir da análise comparativa das soluções adotadas nos croquis, nos projetos e no projeto construído. Para isso, utilizou-se plantas, cortes, perspectivas e documentação fotográfica. Também foi problematizada a seleção dos artistas e dos designers, bem como de suas obras para o palácio, com os dilemas e intenções da equipe, a partir das fontes escritas. Deste modo, foi possível cruzar o que era difundido com o que foi projetado, enriquecendo a leitura do projeto.

Partindo da ideia de promenade architecturale, a análise espacial do Palácio Itamaraty compreendeu a fachada e os quatro pavimentos do edifício representativo. Foi analisada a composição espacial interna, com ênfase no mobiliário, obras de arte e revestimentos, apresentando as mudanças projetuais e agentes durante as etapas do projeto.

Longe de reconstruir as etapas do procedimento projetual envolvido no palácio, bem como as disputas e decisões, a pesquisa documental apresentou elementos que foram esquecidos e alterados de lugar, projetos que demandaram mais atenção, além da temporalidade diversa nas soluções projetuais. Longe de levantar todos os vestígios deixados pelo projeto, a pesquisa desejou refletir como podemos fazer pesquisa em projeto a partir da documentação levantada, com suas lacunas. Esta leitura buscou refletir sobre a complexidade do fazer arquitetura e para lembrar, como disse Georges Perec:

Mi problema con las clasificaciones es que no son duraderas; apenas pongo orden, dicho orden caduca. Como todo el mundo, supongo, tengo a veces un frenesí del ordenamiento; la abundancia de cosas para ordenar, la casi imposibilidad de distribuirlas según criterios verdaderamente satisfactorios, hacen que a veces no termine nunca, que me conforme con ordenamientos provisorios y precarios, apenas más eficaces que la anarquía inicial. 5 (PEREC, 1986, p. 116)

4 Em tradução livre: Meu problema com classificações é que elas não duram; assim que termino uma determinada ordem, ela já prescreveu. Como todo mundo, às vezes tenho uma mania de ordenar as coisas. Mas por causa da abundância de coisas serem ordenadas e da quase impossibilidade de ordená-las em uma classificação satisfatória, nunca chego ao fim. Preciso me deter em uma ordem vaga e provisória, que raramente é mais eficiente que a desordem anterior. 
3 A FORMAÇÃO DAS PARTES 


\subsection{UM PALÁCIO PARA A CONSOLIDAÇÃO DE BRASÍLIA}

Brasília foi inaugurada em 21 de abril de 1960, no governo de Juscelino Kubistchek. O Embaixador José Osvaldo de Meira Penna escreveu Quando mudam as capitais, em 1958, e aponta as especificidades de uma capital:

A Capital exerce uma influência determinante na vida de uma nação. Como sede do governo, órgão de centralização do Estado, centro diretor da vida política e, frequentemente, da vida econômica e cultural do país, ela ocupa uma posição única e privilegiada. Sua importância não reside no volume do comércio ou da indústria, na extensão da área construída ou na cifra de sua população residente, porém na função especial e transcendente de governo e unificação. (PENNA, 2002, p. 20)

A consolidação de Brasília como capital enfrentou as negativas dos funcionários públicos que não desejavam sair do Rio de Janeiro, a então capital. Além disso, a infraestrutura e os ministérios não estavam concluídos nos anos 1960 de modo que Brasília era considerada uma dúvida até 1970. O jornal Correio Braziliense ${ }^{6}$, favorável à nova capital, noticiava cotidianamente o andamento das obras, como observamos no relato do jornalista Manuel Mendes, responsável pela cobertura do Ministério das Relações Exteriores:

O certo é que, quando Juscelino passou o comando a outro Presidente, no dia 31 de janeiro de 1961, Brasília continuava incompleta, com muitos prédios por construir ou terminar e uma grande carência de unidades habitacionais que permitissem a transferência da expressiva maioria dos funcionários que continuavam no Rio, fazendo com que o País tivesse, de fato, duas Capitais. (MENDES, 1995, p. 26)

A partir de 1962, a nova sede do Ministério das Relações Exteriores é vista pelo periódico como fundamental para a consolidação de Brasília como capital, com manchetes como "Mudança do Itamarati está sendo

6 O jornal Correio Braziliense foi fundado em abril de 1960, a mesma data da inauguração de Brasília. Seu idealizador, Assis Chateaubriand, faz referência ao jornal Correio Braziliense de Londres, fundado por Hipólito José da Costa, tido como o primeiro jornal brasileiro. Este periódico, fundado em 1808, foi responsável por difundir clandestinamente ideias liberais, como o fim da escravidão e a monarquia constitucional. 
ultimada", "A importância do Itamarati"8 e "Vasco diz que Palácio dos Arcos dará maior projeção a Brasília”. No entanto, muitos diplomatas não eram favoráveis à mudança. Uma das justificativas era a ausência de moradias, logo rebatida pelo ministério e reproduzida no jornal, em 1964, com "Será assinado amanhã convênio para construção da quadra de apartamentos do Itamarati em Brasília: transferência” ${ }^{\circ}$.

Por outro lado, alguns diplomatas acreditavam que a transferência de sede era uma oportunidade para a reestruturação da instituição e da espacialidade do edifício. Projetos de reforma e de ampliação foram feitos desde, pelo menos, 1942 com o projeto de Henrique Mindlin para o anexo do palacete. A sede carioca não suportava as novas necessidades e demandas do ministério. Para este grupo, a transferência de capital era vista como possibilidade para a modernização do edifício. A mudança visava também criar uma nova imagem: moderna e atenta às novas demandas da diplomacia e do desenvolvimento do país:

A mudança do Itamaraty para Brasília propiciou a adoção de uma série de medidas destinadas à modernização da sua estrutura operativa. A época foi de entusiasmo pioneiro, alimentado pela convicção de que se vivia um momento histórico e que se oferecia uma oportunidade única para uma reorganização geral da Secretaria de Estado. Já no apagar das luzes do ano de 1969 havia sido baixada a Portaria $n^{0} 283$, de 26 de dezembro, que determinara a adaptação do sistema de movimentação do pessoal diplomático e administrativo às condições especiais impostas pela transferência da Secretaria de Estado para Brasília. (CASTRO, 2009, p. 540)

Para além do próprio ministério, o jornal Correio Braziliense difundia a ideia de que a transferência de sede do Ministério das Relações Exteriores levaria à construção das embaixadas. Com as dúvidas sobre a consolidação de Brasília, esperavam o término da construção da sede do ministério para que então iniciassem as obras de suas embaixadas. Porém:

7 Mudança do Itamarati está sendo ultimada. Jornal Correio Braziliense, Brasília, 06 de fevereiro de 1962, p. 1.

A importância do Itamarati. Jornal Correio Braziliense, Brasília, 10 de março de 1966, p. 4.

9 Vasco diz que Palácio dos Arcos dará maior projeção a Brasília. Jornal Correio Braziliense, Brasília, 9 de dezembro de 1965, p. 1.

10 Será assinado amanhã convênio para construção da quadra de apartamentos do Itamarati em Brasília: transferência. Jornal Correio Braziliense, Brasília, 02 de julho de 1964, p. 6. 
Lançada a pedra fundamental há dois anos, ainda hoje o Palácio Itamarati não saiu da estaca zero. Com isso, dezenas de edifícios-sede de Embaixadas não foram nem iniciados, porque não se justifica que estando no Rio o Ministério das Relações Exteriores, venham para Brasília as missões diplomáticas. Com isso, também, agrava-se o problema do desemprego e da situação do comércio de Brasília. ${ }^{11}$

Ademais, segundo o jornal, a construção das embaixadas levaria capital humano e capital financeiro com as novas obras:

\begin{abstract}
A mudança completa e definitiva do Ministério das Relações Exteriores e, consequentemente, das diversas Embaixadas, para Brasília, repousa no seguinte tripé: construção do Itamarati, construção das unidades residenciais destinadas ao pessoal do Ministério das Relações Exteriores e a aprovação recente da Lei que facilita a aquisição, por governos estrangeiros, de imóveis no D. Federal, possibilitando assim a construção de residências para o pessoal dessas Embaixadas. ${ }^{12}$
\end{abstract}

A partir de 1964, com a assinatura do contrato com a Construtora Novacap e a nomeação do então Conselheiro Wladimir Murtinho como Chefe da Comissão de Transferência, a construção do edifício começa de fato e sua divulgação no periódico se torna mais frequente. Entre 1964 até 1970, as manchetes apresentavam a velocidade da obra: "Presidente manda acelerar o andamento das obras no DF"13 ou "O Palácio dos Arcos pronto em janeiro [1965]"14 e até mesmo que "Palácio do Itamarati deverá estar funcionando em Brasília até 1965”15.

Em 1966, o Ministério das Relações Exteriores realizou a Festa da Cumieira, uma forma de apresentar as estruturas do palácio e o bom

11 A realidade de Brasília. Jornal Correio Braziliense, Brasília, 24 de agosto de 1962, p. 4.

12 Autoridades empenham-se na transferência do Itamarati para o DF. Jornal Correio Braziliense, Brasília, 18 de junho de 1964, p. 6.

13 Presidente manda acelerar o andamento das obras no DF. Jornal Correio Braziliense, Brasília, 14 de maio de 1964, p. 8.

14 O Palácio dos Arcos pronto em janeiro. Jornal Correio Braziliense, Brasília, 20 de janeiro de 1966, p. 1.

15 Palácio do Itamarati deverá estar funcionando em Brasília até 1965. Jornal Correio Braziliense, Brasília, 20 de maio de 1964, p. 8. 
andamento da obra para os embaixadores brasileiros e estrangeiros, para os políticos e a sociedade. Mesmo assim, a dúvida acerca de Brasília como capital continuava e em 20 de maio de 1966, o editorial "Capital" do jornal aponta que:

A conclusão do futuro edifício do Ministério das Relações Exteriores e a transferência do corpo diplomático, que ainda se deixa ficar na Guanabara, são de transcendental importância para a definitiva implantação da Capital no Planalto. A fixação das representações estrangeiras nesta terra é muito importante e será mais um passo, um dos mais decisivos, para a irreversibilidade de Brasília e, também, a comprovação da sua viabilidade como Capital. ${ }^{16}$

Frequentemente o jornal associou o palácio com a ideia de beleza e ao discurso de que "o palácio é excepcionalmente grande e bem proporcionado, como o é o Brasil"17, de modo que o palácio era visto como uma obra arquitetônica suntuosa e irradiadora de Brasília. Por isso, era urgente o término de suas obras. O Palácio Itamaraty era apontado como o catalisador da consolidação de Brasília. Uma das justificativas era a transferência de servidores e com isso, o aumento de habitantes. A outra era a construção das embaixadas que mobilizaria o setor da construção civil, gerando mais dinheiro e empregos para capital. Outra justificativa política fundamental era que Brasília se tornaria de fato o centro de visitas de representações estrangeiras:

E é importante notar que a construção do Palácio dos Arcos, como a das representações estrangeiras constituem fator decisivo para a consolidação da sede legítima do país. Algumas embaixadas - convém frisar - confiantes na política de integração do governo revolucionário já trata de edificar as sedes próprias. ${ }^{18}$

Ainda que a inauguração de Brasília tenha acontecido em 1960, sua consolidação como sede política era incerta e instável. A construção da nova sede do Ministério das Relações Exteriores foi vista como fundamental para a consolidação da nova capital.

\footnotetext{
16 Capital. Jornal Correio Braziliense, Brasília, 20 de maio de 1966, p. 1.

17 Vasco diz que Palácio dos Arcos dará maior projeção a Brasília. Jornal Correio Braziliense, Brasília, 9 de dezembro de 1965, p. 1.
} 
3. A FORMAÇÃO DAS PARTES / 37 


\subsection{UM NOME PARA O PALÁCIO}

O processo de nomear nunca é ato banal. Nomear é dar forma a algo. É uma maneira de criar delimitações entre o objeto e o mundo. Pode expressar referências ou lembranças aos fatos pretéritos, sendo assim uma continuidade. Também pode ser o desejo de um vir a ser, uma intenção, uma ruptura. Apesar de haver interesses diversos em uma nomenclatura, seu ato ocorre no presente. Com o passar dos dias, pode ser validado por quem - ou o grupo - que o nomeou. É, portanto, uma intenção histórica. Compreender nomes significa entender o processo de sua escolha, que só pode ser entendido se localizado em algum tempo e espaço. Nomear também significa excluir possibilidades, apagando desejos e intenções. Perder algo. E assim foi com o processo de escolha do nome do edifício da sede do Ministério das Relações Exteriores em Brasília.

Em levantamentos no jornal Correio Brasiliense sobre como o Palácio Itamaraty era descrito e narrado durante o período de construção, percebeuse as várias nomenclaturas referidas ao palácio: Palácio Itamaraty, Palácio Itamarati, Palácio do Itamaraty, Palácio do Itamarati e Palácio dos Arcos. Essa imprecisão nos nomes ocorre não só no jornal Correio Braziliense, mas nos demais meios de circulação de ideias, como outros jornais, revistas e revistas de arquitetura.

No jornal Correio Braziliense, houve matérias e reportagens que discutiam o melhor nome para o palácio. Em 1960, no lançamento da pedra inaugural com Juscelino Kubistchek, o jornalista Manuel Mendes escreve que "Itamarati é o nome que evoca a tradição que enobrece e enobreceu a diplomacia brasileira"19. Já com as obras em andamento, em 1966, o jornalista em sua coluna $O$ Correio Diplomático diz que "O ministro Wladimir Murtinho, Presidente da Comissão de Transferência do Ministério das Relações Exteriores é o grande batalhador dessa obra monumental, pensou em três possíveis nomes: Palácio Rio Branco, Palácio das Bandeiras ou Palácio dos Arcos" ${ }^{20}$. O primeiro nome é uma homenagem ao patrono da diplomacia brasileira, José Maria da Silva Paranhos Junior, também conhecido como Barão de Rio Branco. Palácio das Bandeiras faz referência ao processo histórico de expedições rumo ao interior do Brasil, relacionando-se ao processo de interiorização do país pela construção da nova capital. Palácio dos Arcos, nome muito utilizado pelo habitante de Brasília e os profissionais que trabalharam no projeto do palácio, como Oscar Niemeyer, Milton Ramos e Bernardo Figueiredo, deve-se ao desenho

19 MENDES, Manuel. Nome Itamarati é símbolo para a nossa diplomacia. Jornal Correio Braziliense, Brasília, 13 de setembro de 1960, p. 1.

20 MENDES, Manuel. Correio Diplomático. Nome para o prédio do MRE em Brasília. Jornal Correio Braziliense, Brasília, 9 de janeiro de 1966, p. 9. 
das colunatas do edifício. Ainda nesta reportagem, Manuel Mendes escreve que:

Por que não Palácio do Itamarati? - não se pensou nesse nome para Brasília porque é de um prédio no Rio de Janeiro e que ganhou esse nome muito antes de o Ministério das Relações Exteriores ali se instalar e que era simplesmente o nome do dono do imóvel. ${ }^{21}$

Outra colunista, Yvonne Jean, escreve em 21 de abril de 1966, aniversário de Brasília: "Porque 'Itamarati', no Rio, evoca e deve continuar a evocar um mundo, mas 'Itamarati de Brasília' nada evoca. Nenhuma relação com esta cidade com os barões de Itamaraty" ${ }^{22}$. Yvonne Jean questiona assim o anacronismo da nomenclatura e a sua falta de enraizamento na nova capital. Também explica que o nome Itamaraty, que significa "Rio das Pedras Pequenas”, era o nome dado à residência dos Barões de Itamaraty, na antiga Rua Larga, hoje avenida Marechal Floriano. Entre 1889 a 1898, o palacete foi sede do governo republicano e foi sede do Ministério das Relações Exteriores entre 1899 e 1970, onde as recepções diplomáticas ocorriam. Em outra coluna em abril de $1970^{23}$, Yvonne Jean aponta o gosto público pela já “corriqueira expressão" Palácio dos Arcos.

Na coluna Sociais de Brasília, Katucha escreve que "O Palácio dos Arcos ou Palácio das Colunatas ou Palácio do Itamarati, não importa o nome, já é uma realidade insofismável" ${ }^{24}$. E, portanto, mostra como a escolha do nome para o palácio estava circulando pela capital. O interessante era que havia até mesmo um questionamento sobre o termo técnico do elemento arquitetônico marcante do palácio: arcos ou colunatas.

Mas não foi só no debate público que o nome do palácio foi discutido. Como havia vários nomes dados para o mesmo palácio, o decreto de $\mathrm{n}^{\mathrm{0}}$ 60.502, de 14 de março de 1967, nomeava oficialmente o prédio do Ministério das Relações Exteriores como Palácio Itamaraty, por norma consuetudinária. Mesmo assim não convenceu e em 12 de abril de 1967, o Sr. Senador Vasconcelos Torres apresentou o Projeto de Lei do Senado n. 10, de 1967, em que solicita “ao edifício do Ministério das Relações Exteriores, na Capital da República, a denominação de 'Palácio dos Arcos”, pois "Não

$21 \quad$ Idem.

22 JEAN, Yvonne. Esquina de Brasília. Palácio dos arcos ou Itamarati de Brasília ?. Jornal Correio Braziliense, Brasília, 21 de abril 1966, p. 2. 
nos convenceram, as razões invocadas pelo ex-presidente Castelo Branco, para baixar o Decreto no 60.502" uma vez que "Consagrado já estava, no entanto, o nome que, espontaneamente, surgiu face à própria concepção arquitetônica da majestosa edificação que irá abrigar a direção geral dos serviços diplomáticos brasileiros."

Justificando que deste modo deveriam continuar com o mesmo nome: "o Palácio do Planalto como Palácio do Catête, o Palácio da Alvorada como Palácio da Guanabara, e os edifícios que abrigam o Congresso deveriam, vitoriosa a tese do ex-Presidente, denominar-se, respectivamente, Palácio Monroe e Palácio Tiradentes". O projeto de Lei foi negado com a justificativa que "o nome Itamaraty ultrapassou as fronteiras terrestres do nosso país para representar, entre todos os povos do mundo, a nossa própria Chancelaria."

Wladimir Murtinho sabia bem da importância dos nomes e em 1964, ano do início da construção do palácio, o jornalista Ari Cunha escreve no jornal Correio Braziliense:

O ministro Wladimir Murtinho, diplomaticamente, mandou fazer outra placa, do mesmo formato, igualzinha à anterior, com o nome Ministério das Relações Exteriores. E explica que 'não é o edifício do Palácio do Itamarati que vem para Brasília, mas sim o Ministério’. ${ }^{25}$

A insistência vinda do ministério deve-se ao fato que muitos diplomatas não desejavam sair do Rio de Janeiro. Em seu livro sobre os diplomatas brasileiros, Por dentro do Itamaraty: impressões de um diplomata, o Embaixador André Amado escreve que:

Vivíamos todos no Rio de Janeiro, e o mero boato da mudança para o Planalto Central regelava-nos. Ao Embaixador Wladimir do Amaral Murtinho foi conferida a tarefa de montar e decorar o novo Itamaraty. Muitos acreditam que Murtinho foi escolhido por ser, sem dúvida, pessoa da mais notória sofisticação artística, mas também pela torcida de muitos de que suas imensas virtudes lhe tivessem subtraído o perfil executivo que se reclamava para o difícil encargo de coordenar a mudança para Brasília, com o que o Itamaraty jamais sairia do Rio de Janeiro e lá seguiria glorioso. ${ }^{26}$

25 CUNHA, Ari. Visto, lido e ouvido. Jornal Correio Braziliense, Brasília, 17 de junho de 1964, p. 3 .

26 AMADO, André. Por dentro do Itamaraty: impressões de um diplomata. Brasília: FUNAG, 2013. p. 126. 
Em meio aos debates e disputas acerca do nome para o novo palácio do Ministério das Relações Exteriores, Palácio Itamaraty foi o escolhido. Deste modo, a manutenção do nome do palácio foi responsável pela ideia de que a instituição e a sua tradição iriam continuar em outro local. Não haveria uma ruptura institucional com a mudança de sede do Ministério das Relações Exteriores. 


\subsection{O CLIENTE}

O solicitante do projeto é a instituição responsável pela mediação entre o Estado brasileiro e os outros países. Sua origem data de 1821, com a separação da Secretaria de Negócios Estrangeiros e Secretaria de Guerra. Em 1889, com a Proclamação da República, a então Secretaria de Negócios Estrangeiros passa a ser nomeada como Ministério das Relações Exteriores. Este ministério tem como vocação construir, manter ou romper as relações com outros países, em que o diplomata se coloca em nome do Estado. Após dez anos, em 1899, o ministério ocupa o Palácio Itamaraty, no Rio de Janeiro. Para Rubens Ricupero:

Poucos países devem à diplomacia tanto como o Brasil, e não só em relação ao território. Em muitas das principais etapas da evolução histórica brasileira, as relações exteriores desempenharam papel decisivo. Com seus acertos e erros, a diplomacia marcou profundamente a independência, o fim do tráfico de escravos, a inserção no mundo por meio do regime de comércio, os fluxos migratórios, voluntários ou não, que constituíram a população, a consolidação da unidade ameaçada pela instabilidade na região platina, a industrialização e o desenvolvimento econômico. (RICUPERO, 2017, p. 27)

De modo que a diplomacia atuou na formação do território do Brasil e na construção de ideias sobre a identidade do país, agenciando, sempre, os interesses do Estado.

Tal como a diplomacia, a produção da arquitetura moderna no Brasil também é associada a construção de certa ideia de nação. Arquitetura, moderno e Estado: três termos que mobilizaram diversas pesquisas e reflexões. Carlos Alberto Ferreira Martins mostra em sua dissertação de mestrado a relação intrínseca entre arquitetura e Estado em Arquitetura e Estado no Brasil. Elementos para uma análise da constituição do discurso moderno no Brasil. A obra de Lucio Costa 1924-52. Otília Beatriz Fiori Arantes apresenta Brasília como a etapa consolidadora de um projeto de modernização que ocorreu via Estado e teve início na Semana de 22 em O Lugar da Arquitetura depois dos Modernos. Oscar Niemeyer: forma arquitetônica e cidade no Brasil moderno, de Luiz Recamán, faz uma análise da relação de Niemeyer com o Estado e, dentre outros estudos, João Masao Kamita discorre sobre outros projetos no processo de modernização em Espaço Moderno e País Novo - a arquitetura moderna no Rio de Janeiro. Uma arquitetura que tem o Estado como cliente, que inventa e é criada pela ideia de - certa - brasilidade. Por vezes, é vista como uma mão do Estado, 
ao mesmo tempo que inventa este próprio Estado.

O Ministério das Relações Exteriores também é responsável pela organização de atividades culturais no exterior. Um exemplo disto é a criação de institutos, centro culturais, centro de estudos e Cátedras que têm como característica central a educação como difusor do conhecimento acerca do Brasil. O setor de artes plásticas promovia e apoiava as exposições de artistas brasileiros, mediando as relações entre os artistas e as instituições. Também mediava a relação entre artista e cliente, um exemplo é contado na carta do artista Arthur Luiz Piza, em julho de 1984, para Sergio Camargo em que informa que o ministro Lang gostou muito do Muro no subsolo do palácio, sugerindo para Sergio Camargo que enviasse imagens para Michel Troche, ministro da cultura da França, pois havia interesse em uma encomenda importante ${ }^{27}$.

O ministério também financiava visitas de personalidades estrangeiras ao Brasil, como foi o caso da vinda do crítico de arte Leonelo Ventura, em $1960^{28}$. Há também o trabalho de divulgação, sendo responsável por publicações brasileiras no exterior. Certamente, as fotografias de Brasília feitas por Marcel Gautherot estavam inseridas nesta lógica, como nos conta uma reportagem do jornal Correio Braziliense: "Encontra-se em Brasília o jornalista Marcel Gautherot, repórter fotográfico, incumbido pelo Ministério das Relações Exteriores de fazer reportagem sobre as obras do Palácio do Itamarati, a fim de servir como divulgação, no estrangeiro, da nova sede." ${ }^{9}$

As bienais e os pavilhões são eventos importantes na divulgação da produção brasileira ao exterior. Todo o processo é mediado pelo Ministério das Relações Exteriores, atuando tanto na seleção de obras e artistas, como no auxílio aos processos administrativos. Como exemplo, dentre tantos outros: Sergio Camargo participou da $33^{\circ}$ Bienal de Veneza, em 1966, e Mary Vieira e Burle Marx participaram da 35 Bienal de Veneza, em 1970. Burle Marx também fez o paisagismo do pavilhão do Brasil na Exposição Internacional de Bruxelas, em 1958, projetada por Sergio Bernardes.

A Bienal de São Paulo ${ }^{30}$ fundada em 1951 por Ciccillo Matarazzo e Yolanda Penteado foi fundamental para a consolidação de um sistema de artes plásticas no Brasil. Na $4^{\circ}$ Bienal de São Paulo, em 1957, o Ministério

27 O documento citado é o número 1831 e encontra-se no Fundo Sergio Camargo, no Instituto de Arte Contemporânea.

28 Cf. Relatório do Ministério das Relações Exteriores 1960, p. 50.

29 KATUCHA. Sociais de Brasília. Jornal Correio Braziliense, Brasília, 21 de maio de 1966, p. 11.

30 Até a $6^{\circ}$ Bienal de São Paulo, em 1961, o Museu de Arte Moderna era responsável pela realização do evento. Em 1963, a Fundação Bienal é criada. Ciccillo Matarazzo permaneceu no cargo de presidente até 1975. 
das Relações Exteriores participou da exposição, com a presença de alguns diplomatas na Comissão de Honra, dentre eles a Embaixadora Odette de Carvalho e Souza e o então Conselheiro Wladimir Murtinho. Em 9 de fevereiro de 1966, é assinado o Convênio entre o Ministério das Relações Exteriores e a Fundação Bienal de São Paulo:

Foi assinado, ontem, no Palácio Itamarati, convênio entre o Ministério das Relações Exteriores e a Fundação Bienal de São Paulo. A Fundação dará base mais sólida às futuras bienais, recebendo o Itamarati, em contrapartida, um certo número de obras de arte, dentre as melhores produzidas no País, destinadas à ornamentação de nossas Missões diplomáticas no exterior. Firmaram o convênio o chanceler Juraci Magalhães e o Presidente da Fundação Bienal de São Paulo, sr. Francisco Matarazzo Sobrinho. ${ }^{31}$

O convênio também estabelece o Prêmio Itamaraty para o "melhor artista de todas as categorias”, incentivando a produção artística.

Assim, o solicitante do projeto - Ministério das Relações Exteriores - esteve atento à produção cultural no Brasil, a partir de políticas para incentivar e divulgar tal produção. De modo que já havia um conhecimento prévio sobre esta produção por parte do solicitante o que lhe deu autonomia nas escolhas de obras de arte, mobiliário e tapeçarias. O Ministério das Relações Exteriores em muito já dialogava com instituições culturais do país e do exterior, bem como vários profissionais que participaram do projeto do palácio. Pensemos nas exposições de artistas brasileiros em museus e galerias no exterior, nas Bienais de Arte, na Fundação Bienal de São Paulo e no Museu de Arte Brasileira da Fundação Armando Álvares Penteado (MAB-FAAP). Estes dois últimos, profundamente marcados pela presença do Embaixador Wladimir Murtinho.

31 O governo e a notícia. "Bienal". Jornal Correio Braziliense, Brasília, 11 de fevereiro de 1966, p. 3. 


\subsection{A FORMAÇÃO DAS PERSONAGENS}

O processo de projeto, a execução das obras, a ambientação do palácio até o início da ocupação do edifício percorreu os anos de 1959 até 1970. A construção do Palácio Itamaraty envolveu diversos profissionais ao longo desses onze anos: diplomatas, arquitetos, engenheiros, mestre de obras, marceneiros, operários, paisagistas, artistas, designers, dentre outros. Aqui, apresenta-se parte dos envolvidos, a sua relação com o Itamaraty e a sua participação no desenvolvimento do projeto. Esta seleção ocorreu a partir dos documentos históricos levantados, como o Relatório de Despesas elaborado pelo Embaixador Wladimir Murtinho em Resposta ao Requerimento de Informações no 4308 , de 1968, do Deputado Mendes de Moraes.

Como também há obras de arte de artistas que não participaram do processo, mas que foram adquiridas durante o processo de concepção e construção do Palácio Itamaraty, optou-se por apresentá-los também, dada a relevância das obras no projeto, ao final deste subcapítulo.

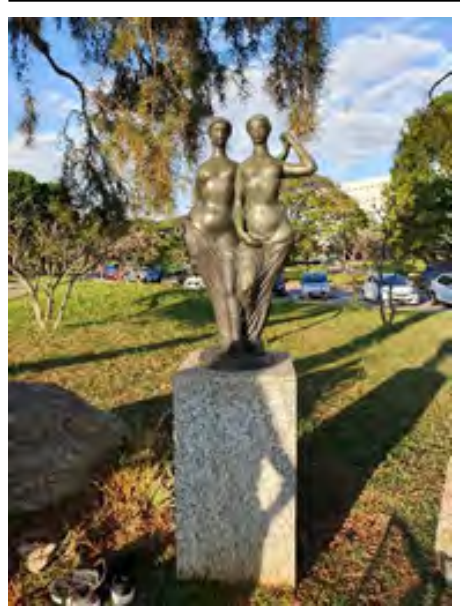

Figura 1: Duas figuras femininas, Alfredo Ceschiatti, 1966.

Fonte: Karen Matsuda, 2019.

\section{ALFREDO CESCHIATTI \\ Brasileiro • 1918-1989 • Artista \\ Duas figuras femininas, 1968, Terceiro Pavimento - Salão Nobre}

Em 1940, ingressa na Escola Nacional de Belas Artes (ENBA), no Rio de Janeiro. Frequentou o ateliê na Biblioteca Nacional com Bruno Giorgi e José Pedrosa. Oscar Niemeyer o conhece ainda estudante, convidando-o para fazer um baixo-relevo na Igreja de São Francisco de Assis. Também para Pampulha, realiza a escultura $O$ Abraço. A obra Duas figuras femininas também pode ser encontrada pelo nome de Duas Amigas ou As irmãs. A obra consta no Relatório de Despesas de Wladimir Murtinho como obra de arte integrada.

O estudo da escultura Duas figuras femininas foi doado por Alexandre Ceschiatti ao Museu de Arte Moderna de São Paulo e está localizado nos jardins do Parque Ibirapuera. 


\begin{abstract}
ALFREDO VOLPI
Ítalo-brasileiro • 1896-1988 • Artista

Visão de Dom Bosco, 1966, Segundo Pavimento

Trabalhou como marceneiro, entalhador e encadernador. Em 1930, participou do grupo Santa Helena, onde conheceu Bruno Giorgi. Juntamente com Di Cavalcanti, recebeu o prêmio de melhor pintor nacional na II Bienal Internacional de São Paulo, de 1953. Em 1958, pinta um afresco na Igreja Nossa Senhora de Fátima, em Brasília, projetada por Oscar Niemeyer.

O afresco Visão de Dom Bosco, também chamado como O sonho de Dom Bosco, demorou 1 mês para a preparação das tintas e 4 dias para ser pintado. A obra consta no Relatório de Despesas de Wladimir Murtinho como obra de arte integrada.
\end{abstract}

\title{
ATHOS BULCÃO
}

Brasileiro • 1918-2008 • Artista

Treliça em madeira, 1967, Segundo Pavimento;

Relevo de Mármore, 1967, Térreo;

Painel de azulejos, 1982, Passarela entre os anexos I e II do Ministério das Relações Exteriores;

Painel de azulejos, Cobertura do Anexo II;

Painel de azulejos, $1968,8^{\circ}$ andar, Edifício Administrativo

Trabalhou como assistente de Cândido Portinari na construção do painel de São Francisco de Assis, na Igreja da Pampulha, em Belo Horizonte. Produziu painéis para diversas obras de Niemeyer, como a Igreja Nossa Senhora de Fátima e o Hotel Brasília Palace, em Brasília, e a Sede da editora Mondadori, em Milão. Também foi responsável pelos painéis nas embaixadas de Buenos Aires, Nova Délhi e Cabo Verde. Athos Bulcão foi responsável pela paginação dos pisos, paredes e vidros da fachada do Palácio Itamaraty.

Relevo de Mármore consta no Relatório de Despesas de Wladimir Murtinho como obra de arte integrada. 


\section{BERNARDO FIGUEIREDO}

Brasileiro • 1934-2012 • Arquiteto

Cadeira dos Arcos, Sofá e Poltrona Embaixador, mesa de reunião e mesas de apoio, Segundo Pavimento - Sala de Reuniões do Conselho da Política Exterior;

Sofá e poltrona Rei, Poltrona Leve, Poltrona Rio, Conversadeira, Cadeira Bahia, Terceiro Pavimento;

Cartão modelo para confecção de tapetes bordados em ponto brasileiro, executados por Madeleine Colaço

Formado pela Faculdade Nacional de Arquitetura, no Rio de Janeiro, em 1957. Projetou residências, arquitetura de interiores, peças de mobiliário e shoppings. Trabalhou com Sergio Rodrigues na OCA. Desenhou diversos mobiliários para a loja Chica da Silva. Tuni Murtinho, esposa do Embaixador Wladimir Murtinho, apreciava sua produção moveleira.

Os mobiliários constam no Relatório de Despesas de Wladimir Murtinho como obra de móveis modernos e estão organizados no documento a partir de sua disposição de ambientes no palácio. No mesmo relatório, o cartão modelo consta como tapetes e tapeçarias.

\section{BRUNO GIORGI}

Brasileiro • 1905-1993 • Artista

Meteoro, 1967, Fachada;

Busto de Alexandre Gusmão, Busto de Duarte da Ponte Ribeiro, Busto do Barão do Rio Branco, 1967, Segundo Pavimento

Estudou desenho e escultura em Roma, em 1920. Participou do Grupo Santa Helena, em que conhece Alfredo Volpi. Fez o Monumento à Juventude Brasileira (1947) para o Ministério da Educação e Saúde, no Rio de Janeiro, e Candangos (1960), na praça dos Três Poderes, em Brasília. Foi professor de Maria Leontina.

Por encomenda do Ministério das Relações Exteriores, fez a maquete de estudo da escultura Meteoro, que lhe rendeu, em 1966, O grande prêmio de escultura em Milão. A escultura de mármore foi talhada no Estúdio Nicole, em Carrara. Tanto as ermas, como a escultura, bem como seus estudos, constam no Relatório de Despesas de Wladimir Murtinho como obra de arte integrada. 


\section{DAREL VALENÇA}

Brasileiro • 1924-2017 • Artista

Pintura sem título, sem localização

Estudou na Escola de Belas do Recife. Foi ilustrador da revista Manchete, Última Hora e Diário de Notícias. Em 1957, recebeu o prêmio de viagem ao exterior do Salão Nacional de Arte Moderna.

O painel com três partes não consta no Relatório de Despesas de Wladimir Murtinho, no entanto é citado na coluna "Atelier", de Hugo Auler, no jornal Correio Braziliense, em 11 de dezembro de 1968, que chegará em breve uma obra do artista no Palácio Itamaraty. Na reportagem "MAM expõe hoje painel com estranha máquina que Darel fez para Brasília”, em 12 de março de 1969, do jornal O Globo, há mais dados sobre a pintura que foi encomendada por Wladimir Murtinho.

DJANIRA DA MOTTA E SILVA

Brasileira • 1914-1979 • Artista

Cena de rua, 1964, Terceiro Pavimento

Autodidata. No Rio de Janeiro, fez o curso de desenho no Liceu de Artes Ofícios, com Emeric Marcier, onde conheceu Milton Dacosta. Seus principais temas eram relacionados à vida cotidiana, retratando festejos populares e o mundo do trabalho.

A pintura Cena de rua também foi chamada como Cesario Bahiano, apesar de aparecer na fotografia de Marcel Gautherot e na coluna Atelier, de Hugo Auler, de 11 de dezembro de 1968, no jornal Correio Braziliense, não há referências sobre a aquisição da obra no Relatório de Despesas de Wladimir Murtinho.

IBERÊ CAMARGO

Brasileiro • 1914-1994 • Artista

Estrutura de objetos, sem localização

Inicia seus estudos no Rio Grande do Sul, na Escola de Artes e Ofícios da Cooperativa da Viação Férrea de Santa Maria. Em 1942, ingressou na Escola Nacional de Belas Artes no Rio de Janeiro. Também frequentou o curso de Guignard.

A pintura Estrutura de objetos não consta no Relatório de Despesas de Wladimir Murtinho, no entanto a obra é citada na coluna "Atelier", de Hugo Auler, no jornal Correio Braziliense, em 11 de dezembro de 1968. 


\section{FAYGA OSTROWER}

Polonesa • 1920-2001 - Artista

7 litografias, sem localização

Muda-se para o Brasil em 1934. Estudou artes gráficas na Fundação Getúlio Vargas, em 1947. Entre 1950 e 1951, deu aulas para Tuni Murtinho. Lecionou no Museu de Arte Moderna do Rio de Janeiro entre 1954 e 1970.

As obras foram encomendadas por Wladimir Murtinho, mas não constam no Relatório de Despesas de Wladimir Murtinho. Porém, é citado na coluna "Atelier", de Hugo Auler, no jornal Correio Braziliense, em 11 de dezembro de 1968, que o ministério adquiriu obras da artista.

\section{FRANZ WEISSMANN}

Austríaco • 1911-2005 • Artista

Metamorfose, sem localização

Fez arquitetura na Escola Nacional de Belas Artes, no Rio de Janeiro, concluindo o curso em 1941. No final dos anos 1940, é convidado por Guignard para dar aulas na Escola do Parque. Foi professor de Mary Vieira.

A escultura Metamorfose não consta no Relatório de Despesas de Wladimir Murtinho, no entanto o artista é citado na coluna "Atelier", de Hugo Auler, no jornal Correio Braziliense, em 11 de dezembro de 1968. Não há menção a sua localização no palácio.

\section{JOAQUIM CARDOZO}

Brasileiro • 1897-1978 • Engenheiro

Projeto da estrutura do Palácio Itamaraty

Formado em engenharia pela Escola Livre de Engenharia de Pernambuco. Trabalhou constantemente com Oscar Niemeyer e foi responsável pelo cálculo das estruturas da Igreja de São Francisco de Assis, em Belo Horizonte, Congresso Nacional, Palácio da Alvorada, Palácio do Planalto e Catedral Metropolitana, em Brasília, dentre outros. Era também poeta. 


\title{
JOAQUIM TENREIRO
}

\author{
Português • 1906-1992 • Artífice
}

Cadeiras em latão polido, revestidas de veludo vermelho e mesas conjugáveis, Terceiro Pavimento - Sala Brasília

Mudou-se para o Brasil em 1908, aos dois anos de idade. Trabalhou como marceneiro com o pai. Em 1928, no Rio de Janeiro, fez cursos no Liceu de Artes e Ofício. Em 1931, participou do Núcleo Bernardelli, em que conhece Milton Dacosta. Foi responsável pelo mobiliário da residência de Francisco Inácio Peixoto, em 1942, localizada em Cataguases e projetada por Niemeyer. É conhecido pelo uso do jacarandá e da palhinha, no entanto sua produção é vasta e artesanal. Chegou a produzir móveis em metal. Também tem uma produção em artes plásticas, sobretudo, de esculturas.

A cadeira para o salão de banquetes do palácio parte do desenho da cadeira Estrutural, porém sem curvas no espaldar. As peças constam no Relatório de Despesas de Wladimir Murtinho como móveis modernos.

\section{JORGE HUE}

Brasileiro • 1923 - • Arquiteto de interiores

Responsável pela ambientação do Salão de Baile, Terceiro Pavimento;

Padrão de 4 tapetes e 2 passadeiras tecidas à mão pela Fábrica Santa Helena;

Sofá e poltrona Rei e Conversadeira, em colaboração com Bernardo Figueiredo, Terceiro Pavimento - Salão de Baile

Formado em Sociologia pela PUC-RJ, em 1947. Estudou pintura com o artista Pedro Correa de Araújo (1881-1955). Desenvolveu o projeto do Jockey Club do Rio de Janeiro com Lúcio Costa, em 1966. Conhecido por seus projetos de arquitetura de interiores e também pelo conhecimento em Humanidades.

Todas as obras citadas constam no Relatório de Despesas de Wladimir Murtinho como móveis modernos ou tapetes e tapeçarias. 


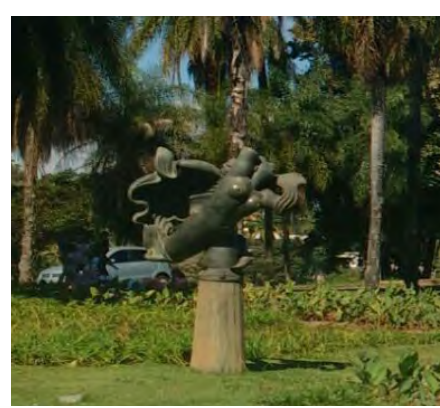

Figura 2: Pampulha, José Pedrosa, 1943.

Fonte: Michelle Pacheco, 2017.

\section{JOSÉ PEDROSA}

\author{
Brasileiro • 1915-2002 • Artista
}

A Pomba, Segundo Pavimento - Sala de Reuniões do Conselho da Política Exterior

Em 1936, estudou no curso livre de escultura da Escola Nacional de Belas Artes do Rio de Janeiro. A pedido de Oscar Niemeyer, em 1943, fez a escultura Pampulha para o Cassino. Dividiu o ateliê com Alfredo Ceschiatti e Bruno Giorgi.

A escultura consta no Relatório de Despesas de Wladimir Murtinho como obra de arte não-integrada, está nomeada como Pássaro e foi executada em 1952.

\section{KARL HEINZ BERGMILLER}

\section{Alemão • 1928 - • Designer}

Mesas, Terceiro Pavimento - Salão Nobre;

Mobiliário de escritório para o Edifício Administrativo

Formado em design pela Escola de Ulm, onde foi aluno de Max Bill. Veio ao Brasil em 1950. Fundou a ESDI (Escola Superior de Desenho Industrial), onde foi professor entre 1963 a 1980. É conhecido por ser pioneiro em Desenho Industrial no Brasil.

O mobiliário de escritório do Edifício Administrativo do Itamaraty foi pensado a partir de um sistema padronizado. As 75 mesas constam no Relatório de Despesas de Wladimir Murtinho como móveis modernos e seriam utilizadas nas festas no Salão Nobre, no terraço.

\section{LÍVIO LEVI}

Ítalo-brasileiro $• 1933-1973 \cdot$ Arquiteto

Luminárias

Formado em arquitetura pelo Mackenzie, em 1956. Foi professor de Desenho Industrial no Mackenzie e na Fundação Armando Alvares Penteado (FAAP). Trabalhou com Henrique Mindlin e Giancarlo Palanti. A partir da encomenda das luminárias para o Palácio Itamaraty, feitas de modo experimental, inicia seu trabalho na área, sendo conhecido por seu pioneirismo em projeto de iluminação no Brasil. Fez o projeto de iluminação da Catedral Metropolitana de Brasília, Pavilhão do Anhembi, Centro Cívico de Santo André e Edifício Manchete. 
LUIZA MILLER

Brasileira • Artista

Pássaro de Fogo, Terceiro Pavimento - Pequeno Salão

O crítico Jayme Maurício apresenta em "Artista brasileira conhecida em Paris antes do Brasil”, publicado no jornal Correio da Manhã, em 03 de maio de 1962, a boa avaliação da crítica sobre as esculturas da artista.

Também diz que "Luiza Miller exibiu entre dez outros trabalhos de bronze, o belíssimo Pássaro de Fogo que o ex-presidente encomendou para Brasília”. A obra foi doada para o Ministério das Relações Exteriores e a escultura de bronze consta no Relatório de Despesas de Wladimir Murtinho como doação.

\section{MADELEINE COLAÇO}

Marroquina-brasileira • 1907-2001 • Artista

Tapeçaria Mapa de Marini, Segundo Pavimento-Sala de Reuniões do Conselho da Política Exterior;

Execução de 2 tapetes bordados em ponto brasileiro a partir do cartão modelo de Bernardo Figueiredo

Estudou tapeçaria na Escola do Palácio de Kasbah, no Marrocos, em 1925. A partir de 1928, morou em Lisboa e aprendeu a técnica tradicional do ponto em Arraiolos. Posteriormente, criou a técnica Ponto Brasileiro, registrada no Centre International de la Tapisserie, em Lausanne. Técnica utilizada para bordar a tapeçaria Mapa de Marini. Os motivos de suas obras são a fauna e a flora.

Todas as obras citadas constam no Relatório de Despesas de Wladimir Murtinho como tapetes e tapeçarias.

\section{MANABU MABE}

Nipo-brasileiro $・ 1924-1997 \cdot$ Artista

Juramento, 1967, Terceiro Pavimento

Autodidata, conhecido como pintor do abstracionismo informal. Em 1956, participou da Bienal de Arte do Japão e, em 1959, obtém o prêmio de melhor pintor nacional da V Bienal de São Paulo e também o prêmio na I Bienal dos Jovens de Paris. Em 1960, é premiado na XXX Bienal de Veneza.

A pintura consta como obra de arte não integrada no Relatório de Despesas de Wladimir Murtinho. 


\section{MANUEL MENDES}

Brasileiro • 1926-2017 • Jornalista

Mudou-se para Brasília em 1957. Trabalhou como jornalista no jornal Correio Braziliense, a partir de 1964, escrevendo para as colunas "Correio Diplomático" e "Mala Diplomática" durante a construção do Palácio Itamaraty. Foi responsável pela cobertura do cotidiano da transferência e os bastidores da diplomacia brasileira, bem como da construção de Brasília.

\section{MARCEL GAUTHEROT}

Francês • 1910-1996 • Fotógrafo

Formado em arquitetura de interiores pela École Nationale des Arts Décoratifs, na França. Foi ao ler Jubiabá, de Jorge Amado, que se interessou pelo Brasil. Sua primeira viagem ao país foi em 1939. Trabalhou para a revista Cahiers d'Art e, no Brasil, para a revista $O$ Cruzeiro. Também trabalhou no Serviço do Patrimônio Histórico e Artístico Nacional (Sphan). Com frequência, fotografou projetos de Oscar Niemeyer . É conhecido por suas fotografias que retratam a construção de Brasília.

\section{MARIA LEONTINA}

Brasileira • 1917-1984 • Artista

Os Episódios III, 1959, Terceiro Pavimento - Introdutor Diplomático

Em 1946, frequenta o ateliê de Bruno Giorgi. Casa-se com o pintor Milton Dacosta em 1949. Suas pinturas, a partir dos anos 1950, tornam-se abstratas, quase geométricas, mas com formas em que o rigor da linha não existe. Recebe o prêmio nacional da Fundação Guggenheim em 1960.

No Relatório de Despesas de Wladimir Murtinho, classificada como obra de arte não integrada, consta a pintura Jogos que provavelmente foi nomeada posteriormente como Os Episódios III. 


\section{MARIA MARTINS}

Brasileira • 1894-1973 • Artista

A Mulher e sua Sombra, 1949, Térreo;

Canto à Noite, 1968, Terceiro Pavimento

Começa os estudos em escultura em 1926, com Oscar Jesper. Foi casada com o Embaixador Carlos Martins Pereira e Souza. Morou em Nova York, onde estudou escultura com Jacques Lipchitz nos anos 1940. Durante este período, conviveu com André Breton, Max Ernst e Marcel Duchamp. Era conhecida como escultora surrealista. Foi responsável pela organização das primeiras Bienais de São Paulo.

Canto à Noite consta no Relatório de Despesas de Wladimir Murtinho como obra de arte integrada e A mulher a sua sombra como doação.

\section{MARY VIEIRA}

\section{Brasileira • 1927-2001 • Artista}

Polivolume: Ponto de Encontro, 1969, Térreo

Estudou com Guignard nos anos iniciais de sua formação. Em 1944, estudou na Escola de Belas Artes de Belo Horizonte. Também foi aluna de Franz Weissmann e Amilcar de Castro. Em 1966, torna-se professora da Escola Superior de Arte, Técnicas de Planejamento Gráfico e Desenho Industrial, da Universidade da Basiléia, Suíça. Fez o cartaz brasilien baut brasilia (brasil constrói brasília) em que apresenta Brasília na exposição Interbau, em 1957, em Berlim. A obra Polivolume: conexão livre - homenagem a Pedro de Toledo foi concebida em 1953, executada em 1966 e instalada no Parque Ibirapuera, em São Paulo, no ano de 1979. Participou junto com Burle Marx da XXXV Bienal de Veneza, em 1970.

A obra para o Palácio Itamaraty foi encomendada por Oscar Niemeyer e não consta no Relatório de Despesas de Wladimir Murtinho.

\section{MILTON DACOSTA}

\section{Brasileiro • 1915-1988 • Artista}

Figura, 1951, Terceiro Pavimento - Pequeno Salão;

Castelo em cinza e vermelho, Terceiro Pavimento;

Madona, sem localização

Funda o Núcleo Bernardelli em 1931, com Edson Motta, Bustamante Sá e Ado Malagoli. Em 1944, recebeu o prêmio de viagem ao exterior na Divisão Moderna do Salão Nacional de Belas Artes. Casa-se com Maria Leontina em 1949.

As obras Castelo em cinza e vermelho e Madona constam no Relatório de Despesas de Wladimir Murtinho como obra de arte não integrada. Não há referências para a pintura Figura. 
MILTON RAMOS

Brasileiro • 1929-2008 • Arquiteto

Escada Helicoidal, 1964, Térreo;

Detalhamento e execução do projeto de arquitetura do Palácio Itamaraty

Formado em arquitetura pela Faculdade Nacional de Arquitetura da Universidade do Brasil, no Rio de Janeiro, em 1958. Ao terminar os estudos vai para Brasília, onde trabalhou na Novacap entre 1958 e 1968. Foi durante este período que desenvolveu o projeto do Palácio Itamaraty, em que executava ao mesmo tempo que detalhava o projeto. Fez, dentre outros, o projeto da sede do Instituto Histórico e Geográfico - DF, o aeroporto de Confins e a embaixada brasileira em Washington, junto com Olavo Redig de Campos.

\section{OLAVO REDIG DE CAMPOS}

\section{Brasileiro • 1906-1987 • Arquiteto}

Formado em arquitetura pela Universidade de Roma. Foi Chefe do Serviço de Conservação do Patrimônio do Itamaraty desde 1946, sendo responsável, junto com Wladimir Murtinho, pelo desenvolvimento do projeto do Palácio Itamaraty. Projetou o Centro Cívico de Curitiba, a residência da família Moreira Salles, no Rio de Janeiro, além das embaixadas brasileiras em Washington, com Milton Ramos, Lima e Buenos Aires. 


\section{OSCAR NIEMEYER}

Brasileiro • 1907-2012 • Arquiteto

Desenho do Palácio Itamaraty

Formado em arquitetura pela Escola Nacional de Belas Artes, no Rio de Janeiro, em 1934. Na obra de Oscar Niemeyer, o edifício do Ministério das Relações Exteriores é o primeiro que utiliza o concreto aparente com a solução em arcadas. O desdobramento formal desta solução é o Ministério da Justiça (1961), Sede da Editora Mondadori (1968), em Milão, e Centro Internacional de Exposições Rachid Karami, em Trípoli (1962). No primeiro, uma caixa de vidro está dentro de uma estrutura de concreto aparente. Cada fachada tem uma solução formal e a caixa de vidro fumê é semelhante ao Palácio Itamaraty, mas o concreto não tem acabamento. A sede da Mondadori, o projeto mais semelhante ao Itamaraty, foi um pedido do proprietário da editora ao arquiteto para que o projeto fosse semelhante ao Ministério das Relações Exteriores. É formado por uma planta retangular com as arcadas não equidistantes, mas com o desenho das ripas. E, em Trípoli, não há o desenho das ripas no concreto, no entanto, o movimento visual é dado pela inclinação dos planos da fachada. Durante a construção do palácio Itamaraty, o arquiteto estava exilado em Paris.

\section{PEDRO CORREIA DE ARAÚJO}

\section{Brasileiro • 1930-2019 • Artista}

Revoada de Pássaros, 1968, Terceiro Pavimento

É o filho mais velho do artista Pedro Luiz Correia de Araújo, que foi formado no início do século XX, com uma produção ora nacionalista, ora erótica. Estudou cerâmica e fez esculturas em pedra sabão e bronze, além das joias. Em 1965, recebeu a medalha de ouro da VIII Bienal de São Paulo. Também fez lustres para o Jockey Club Brasileiro, no Rio de Janeiro.

No Relatório de Despesas de Wladimir Murtinho, sua obra é nomeada como luminária-escultura e consta como obra de arte integrada. Após a inauguração do palácio, fez estudos para o corrimão da escada helicoidal.

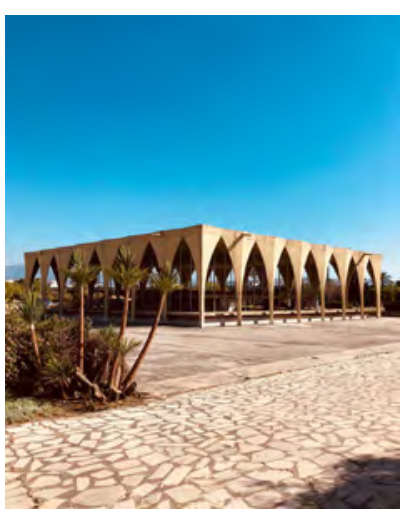

Figura 4: Centro Internacional de Exposições Rachid Karami, Oscar Niemeyer, 1962.

Fonte: Pedro Sunye, 2019. 
ROBERTO BURLE MARX

Brasileiro • 1909-1994 • Paisagista

Jardim Externo, 1966;

Jardim do Primeiro Andar, 1966;

Jardim suspenso, 1966, Terceiro Pavimento;

Tapeçaria Vegetação do Planalto Central,1965, Terceiro Pavimento - Sala Brasília

Formado pela Escola Nacional de Belas Artes em 1934. Burle Marx não fez os jardins em Brasília, como conta Wladimir Murtinho:

"Oscar Niemeyer, começou a fazer o planejamento, eu disse da importância de que ele tivesse como colaborador o Roberto Burle Marx. É necessário dizer que nesse tempo Roberto Burle Marx havia brigado com o Juscelino Kubitschek, e em consequência tinha se estremecido com o Niemeyer. Por esse motivo ele não veio no começo de Brasília, Juscelino não o trouxe porque o nosso Roberto Burle Marx é muito desbocado, ele se queixou aos jornais de que não haviam pago, ele tinha feito os jardins de Pampulha. E se queixou de que não haviam pago, que aquilo tinha sido uma vergonha, etc., etc. Então quando veio o momento, porque ele havia sido a pessoa ligada a algo fundamental, que eram os jardins do Ministério da Educação, no Rio de Janeiro. E portanto, o natural teria sido que ele viesse, mas ele não veio no começo, por esse motivo. Sempre fui muito amigo do Roberto Burle Marx, eu disse: "É preciso trazer o Burle Marx pra fazer os jardins." E aí, tive a alegria de poder reconciliá-los e ficar. O Roberto Burle Marx é o melhor que pode ter, não há dúvida sobre isso. E resultou que o Roberto Burle Marx, veio." (MURTINHO, 1990, p. 13.)

Burle Marx teve contato constante com a diplomacia brasileira com a mostra em Washington em 1954, exposição na Suíça, em 1956, paisagismo da exposição do pavilhão brasileiro em Bruxelas, com projeto de Sergio Bernardes, em 1958. Em 1963, fez o paisagismo do pavilhão brasileiro no Japão com indicação de Murtinho. Participou junto com Mary Vieira da XXXV Bienal de Veneza de 1970. Além disso, Tuni Murtinho, esposa de Murtinho, foi aluna de Burle Marx.

\section{SERGIO CAMARGO}

Brasileiro • 1930-1990 - Artista

Muro escultórico, 1966, Subsolo

Estudou na Academia Altamira em Buenos Aires, onde foi aluno de Emilio Pettoruti e Lucio Fontana. Em 1961, passa a residir na França, cursando Filosofia na Sorbonne. Com seus "relevos”, tornou-se um nome fundamental do Construtivismo brasileiro.

No Relatório de Despesas de Wladimir Murtinho, a obra que foi pensada em 1965 consta como obra de arte integrada. 


\section{SERGIO RODRIGUES}

\section{Brasileiro • 1927-2014 • Arquiteto}

Mesa do ministro e versão da Poltrona Kiko, sofás, versão da Poltronas Parati, Mesas de apoio, Mesas-vitrines, Segundo Pavimento

Formado em arquitetura pela Faculdade Nacional de Arquitetura, no Rio de Janeiro, em 1951. Trabalhou no projeto do Centro Cívico de Curitiba com Olavo Redig de Campos. Trabalhou também na Móveis Artesanal, Forma e OCA. Projetou o mobiliário para a Universidade de Brasília (UNB) e Editora Manchete. A Poltrona Mole e Poltrona Cantù foram premiadas no Concorso Internazionale del Mobile, na Itália, em 1961.

Segundo consta no Relatório de Despesas de Wladimir Murtinho, Sergio Rodrigues foi responsável pela ambientação $e$ os móveis do Gabinete do Ministro, do Secretário-geral, do Subsecretário, do Salão dos Embaixadores e do Vestíbulo de Honra.

\section{SÔNIA EBLING}

Brasileira $\cdot 1928-2006 \cdot$ Artista

Sem título, sem localização

Estudou na Escola de Belas Artes do Rio Grande do Sul e do Rio de Janeiro entre 1944 e 1951. Recebeu o prêmio de viagem ao exterior do Salão Nacional de Arte Moderna do Rio de Janeiro em 1955. A escultura Arminda faz parte do acervo do MuBE.

Em 1968, fez um mural de 3 metros por 3 metros, encomendado por Wladimir Murtinho, para o Palácio Itamaraty. Não há informações sobre esta obra no Relatório de Despesas de Wladimir Murtinho. Nem sobre sua localização no palácio.

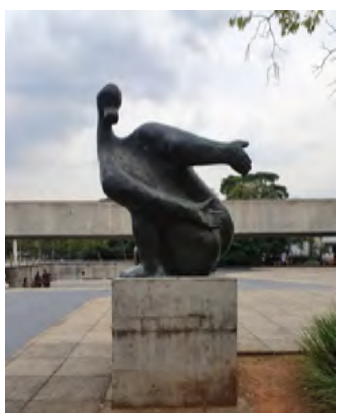

Figura 5: Arminda, Sônia Ebling, c. 1980.

Fonte: Karen Matsuda, 2019. 
WLADIMIR DO AMARAL MURTINHO

Brasileiro $\cdot 1919-2003 \cdot$ Diplomata

Ingressa na carreira diplomática no início dos anos 1940. Entre 1958 a 1960, foi diretor de relações culturais do Itamaraty, momento em que entra em contato com os projetos iniciais da nova sede do Ministério das Relações Exteriores em Brasília. Entre 1961 a 1963, foi Conselheiro na embaixada brasileira no Japão. A partir de 1963, foi Chefe da Comissão de Transferência até 1969. Foi transferido para a embaixada na Índia, meses antes da inauguração do Palácio Itamaraty, sendo substituído pelo diplomata Ciro Espírito Santo Cardoso. Também foi Secretário de Educação e Cultura do Distrito Federal nos anos 1970. Além disso, fez parte do Conselho inicial do Museu de Arte Brasileira da FAAP, escolhido por Lúcia Pinto de Souza, primeira diretora da instituição. Foi membro da Comissão de Honra da Bienal de São Paulo. Foi casado com a artista Tuni Murtinho, que foi aluna de Burle Marx e Fayga Ostrower. 


\title{
ANTÓNIO MANUEL DA FONSECA
}

\author{
Português • 1796-1890 • Artista \\ Retrato de Guedes Pinto, Segundo Pavimento
}

Foi professor de Pintura Histórica na Academia de Belas Artes de Portugal.

Pintado em 1832, o quadro retrata Guedes Pinto, que foi cônsul do Império do Brasil em Roma. A obra é citada na matéria "O que ver no Itamarati", de 19 de abril de 1969, no jornal Correio Braziliense, e estava localizada no Gabinete do Ministro. Atualmente a pintura está no Palácio Itamaraty do Rio de Janeiro.

\section{CÂNDIDO PORTINARI}

\author{
Brasileiro $\cdot 1903-1962 \cdot$ Artista \\ Estudo para o painel "Paz", sem localização; Estudo para o painel \\ "Guerra", sem localização;
}

Os Jangadeiros, sem localização; Os Gaúchos, sem localização

Estudou na Escola Nacional de Belas Artes em 1919, onde foi aluno de Rodolfo Amoedo. Foi professor de Burle Marx. Fez os painéis para o Ministério da Educação e Saúde no Rio de Janeiro. O painel Guerra e Paz foi encomendado para a sede da ONU em Nova Iorque em 1956, e lhe rendeu o prêmio Guggenheim.

Em 15 de agosto de 1964, é noticiado que: "Chegou há poucos dias para adornar a residência do Ministro das Relações Exteriores o quadro "Guerra e Paz" de Portinari, vale cerca de 12 milhões de cruzeiros, teve as molduras parcialmente destruídas", pela reportagem "Violento incêndio destrói três pavimentos do Bloco 11 da Esplanada dos Ministérios" sobre o incêndio que ocorreu no edifício que o Ministério das Relações Exteriores ocupou temporariamente.

Há também as pinturas Os Jangadeiros e Os Gaúchos, provavelmente sobre essas pinturas de cerca de 1939, Wladimir Murtinho diz que:

"Há uma coisa extraordinária nele, os dois grandes Portinaris, que estão lá, são extraordinários, faziam parte da exposição de 1939, exposição universal, que se fez em Nova York. Estiveram lá e depois foram para embaixada. Na embaixada, eu estive lá e pedi ao embaixador que me cedesse, e ele se opôs absolutamente. O Gíbson Alves Barboza, quando veio para ser ministro, trouxe, mandou buscar imediatamente os dois quadros, porque claro, era indispensável que viessem." (MURTINHO, 1990, p. 15)

É apenas em 30 de outubro de 1969 que Gíbson Alves Barboza assume o cargo de Ministro do Ministério das Relações Exteriores. Não foram encontrados mais registros acerca destas duas pinturas de Portinari portanto, não é possível saber se Os Jangadeiros e Os Gaúchos já estavam no palácio na inauguração. 


\section{DELFIM JOAQUIM MARIA MARTINS DA CÂMARA}

Brasileiro $\cdot 1834-1916 \cdot$ Artista

Retrato de D. Pedro II, Segundo Pavimento - Salão dos Embaixadores

Foi professor na Escola Politécnica do Rio de Janeiro e lutou na guerra do Paraguai.

A obra é citada na matéria "O que ver no Itamarati", de 19 de abril de 1969, no jornal Correio Braziliense e em fotografias de Marcel Gautherot.

\section{E. RIVIÈRE}

Rio de Janeiro, aquarela de 1831, sem localização

Consta no Relatório de Despesas de Wladimir Murtinho como obra de arte não integrada.

\section{EMIL BAUCH}

Vistas do Recife, 10 litografias do século XIX, sem localização

Constam no Relatório de Despesas de Wladimir Murtinho como obra de arte não integrada.

\section{MARTINET}

Pôrto do Rio de Janeiro, litografia do século XIX, sem localização

Consta no Relatório de Despesas de Wladimir Murtinho como obra de arte não integrada. 


\section{LEON TIRODE}

\section{Francês • 1873-1956 • Artista}

Reconhecimento do Império do Brasil e sua independência (entrega de credenciais do Embaixador Charles Stuart), Segundo Pavimento - Salão dos Embaixadores

Pintor da escola francesa.

A obra é citada na matéria "O que ver no Itamarati", de 19 de abril de 1969, no jornal Correio Braziliense, e em fotografias de Marcel Gautherot.

\section{PEDRO AMÉRICO}

Brasileiro $\cdot 1843-1905 \cdot$ Artista

Grito do Ipiranga, Segundo Pavimento - Sala do Ministro

Estudou na Academia Imperial de Belas Artes e na École National Superiéure des Beaux-Arts. Batalha do Avaí, Independência ou mortee Paz e Concórdia são as pinturas históricas mais conhecidas de Pedro Américo. Aliás, Paz e Concórdia faz parte do acervo do Palácio Itamaraty do Rio de Janeiro, na pintura há um esboço da pintura Grito do Ipiranga.

A obra é citada na matéria "O que ver no Itamarati", de 19 de abril de 1969, no jornal Correio Braziliense e também aparece em fotografias de Marcel Gautherot.

\section{RODOLFO AMOEDO}

Brasileiro • 1857-1941 • Artista

Retrato de D. João V, Segundo Pavimento;

Retrato de D. Pedro I, Segundo Pavimento

Foi professor da Escola Nacional de Belas Arte do Rio de Janeiro, responsável pela mudança no ensino da escola, nos fins do século XIX. Foi professor de Cândido Portinari.

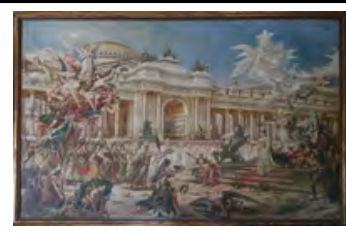

Figura 6: Paz e Concórdia, Pedro Américo, 1895.

Fonte: Karen Matsuda, 2020. 


\subsection{OS PRIMEIROS PROGRAMAS E PROJETOS PARA O PALÁCIO}

Quatro programas de necessidades foram elaborados para o projeto da sede do Ministério das Relações Exteriores em Brasília. Três estão no arquivo do Setor de Arquitetura do Ministério das Relações Exteriores (SARQ) e um foi publicado pela Revista Habitat. Com exceção do que foi publicado pela revista, em 1959, todos os demais estão sem datas. Entendese que estes documentos são anteriores a $1964^{32}$, pois a partir deste ano já é possível verificar nos projetos soluções distintas das que estão nos programas encontrados.

Dois anteprojetos foram elaborados, sendo que dois croquis foram publicados na mesma matéria da Revista Habitat e há três plantas, sem datação, que estão no Setor de Arquitetura do Ministério das Relações Exteriores.

Sobre o projeto do ministério que ocupa 72.000 metros quadrados, foi dito que, entre 1959 e 1964:

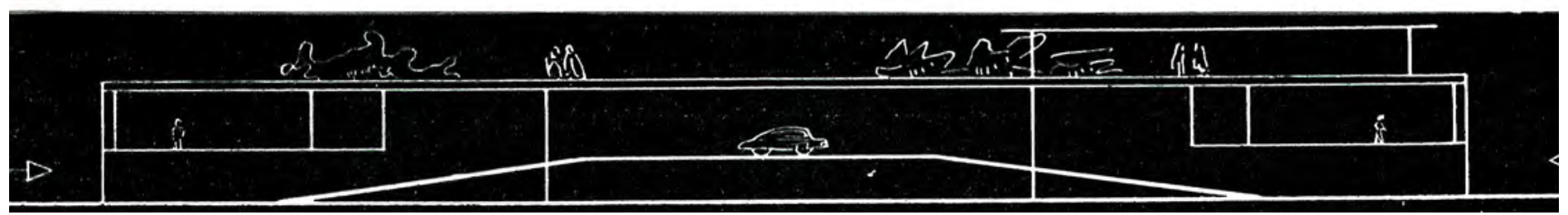

Figura 7: Corte esquemático de um dos projetos iniciais para o Ministério das Relações Exteriores. Fonte: Revista Habitat n 52, 1959.

32 Conforme o Relatório de Despesas de Wladimir Murtinho, o primeiro convênio firmado com a Construtora Pederneiras foi em 1962 e em 1964, é assinado outro contratado com a construtora. 
Relativamente ao Palácio do Itamarati, Niemeyer fez três projetos, 'porque vinha um ministro e queria alterações que o outro não aceitava'. Finalmente o sr. San Tiago Dantas [ministro das Relações Exteriroes entre 1961 e 1962] determinou ao profissional que adotasse a forma e a estrutura que melhor entendesse. ${ }^{33}$

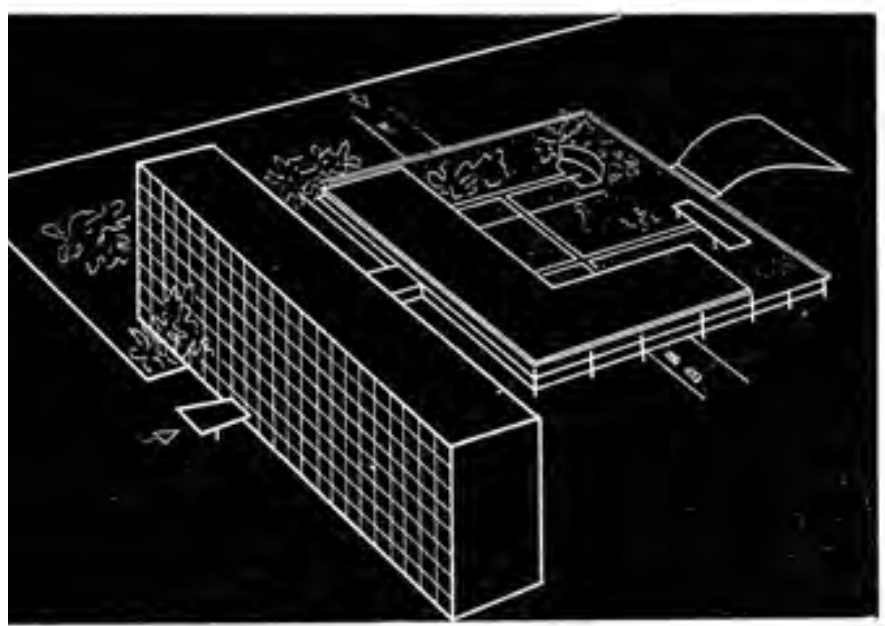

Figura 8: Perspectiva de um dos projetos iniciais para o Ministério das Relações Exteriores. Fonte: Revista Habitat n 52, 1959.

A primeira referência ao programa do palácio foi publicada pela Revista Habitat $n^{0}$ 52, em janeiro de 1959, na matéria "Palácio Rio Branco, Brasília", escrita por Jayme Maurício. O crítico aponta que o edifício administrativo seria um dos edifícios padronizados dos ministérios e estaria ligado por um passadiço ao prédio representativo, este seria formado por dois andares e um jardim suspenso, com três divisões: Gabinete do Ministro, Conferências Internacionais e Dependências Sociais. O primeiro andar destinado ao Ministro seria composto por:

a) Sala do Ministro. Chefia do Gabinete. Salas dos oficiais de Gabinetes, Sala dos Auxiliares. b) Chefia do Cerimonial, Introdutor diplomático, Salas para os funcionários do Cerimonial, Sala para a Ordem Nacional Cruzeiro do Sul. c) Chefia do Serviço de Imprensa, Salas para os funcionários, Sala de jornalistas. d) Consultoria Jurídica, Seção de Acordos Internacionais, Auxiliares da Consultoria Jurídica. e) Ante-sala, Salão dos Tratados, Salão para pequenas recepções, Sala para almoços íntimos. (MAURÍCIO, 1959, p. 2)

33 SIMÕES, Carlos. A cidade dos meus sonhos (VIII). Mexeram no plano residencial. Jornal Correio Braziliense, Brasília, 16 de abril de 1970. p. 26. 
A parte destinada às conferências internacionais estaria no térreo, com o Plenário. No primeiro andar, estariam as salas para os delegados, restaurante e sala para reunião. Por fim, as dependências sociais ficariam na laje do segundo andar com grandes salões, terraço com jardim, espelho d'água e um palco, além de copa e sala de banquetes para 480 pessoas. A circulação seria feita por rampas e escadas.

O eixo principal deste projeto é o terraço com jardim e as rampas, além da planta quadrada para o edifício representativo. As colunas são cilíndricas e sem expressividade. Já se observa o desejo de soltar o último pavimento, bem como a criação de ambientes que possibilitassem um caminhar fluido. A solução do terraço e das rampas deve-se, como explica Wladimir Murtinho:

As pessoas sobem com naturalidade, mas quando voltam, quando querem voltar é terrível, porque aí, todo mundo fica esperando fazer. Esse problema de como resolver isto, foi uma das dúvidas que tínhamos e que discutimos muito com o Oscar Niemeyer, se colocava grandes elevadores para levar todo mundo do térreo para o... para o segundo andar, mas chegou-se à ideia e que foi a adotada, de patamares, os andares funcionam por patamares. Então você tem enormes salões onde as pessoas descansam, e depois sobem, porque ninguém subiria dois andares assim correndo. Isto funcionou muito bem. (MURTINHO, 1990, p. 8)

Há três programas propriamente ditos. No primeiro programa, o edifício representativo ainda é formado dois andares, como o que foi divulgado por Jayme Maurício, e há o Anexo II destinado à área de biblioteca, mapoteca, arquivo e comunicações, segundo Murtinho:

San Tiago Dantas, ele estudou e fez o seguinte comentário, que eu acho extraordinário, porque isto era 61, o San Tiago é de 61, ele disse o seguinte: "É, mas tá faltando aqui um lugar para a programação e a informática, toda a parte de publicações e planejamento da informática, é preciso fazer um terceiro edifício. (MURTINHO, 1990, p. 11)

Além do Anexo II, o Anexo I era destinado aos escritórios, aos cursos do Instituto Rio Branco e ao lazer, com restaurante e clube. No térreo do edifício representativo, teríamos o auditório, salas para reuniões e gabinetes. No primeiro andar, os gabinetes do Ministro - com sala de estudos e um apartamento pequeno - e dos Subsecretário de Estado, Secretário Geral de Política Exterior, Sala do Conselho de Política Exterior, Secretário Geral de 
Serviços Exteriores, Introdutor Diplomático, Sala de Embaixadores, Sala de Imprensa e Cerimonial. O primeiro andar era destinado aos escritórios. Não havia espaços para as recepções.

Outro programa está em uma pasta da Construtora Pederneiras de 1964, entende-se que o seu desenvolvimento data de 1962 a 1963. Neste programa, o edifício é formado por três pavimentos. No térreo, encontraríamos o hall de entrada, a biblioteca, a mapoteca, o hall do ministro e a portaria. Os acessos e os lugares destinados ao conhecimento estariam neste pavimento, recebendo, de certo modo, os convidados.

O primeiro andar seria composto pelo gabinete do ministro de Estado, sala de repouso do ministro, chefe de gabinetes, salas auxiliares, sala de reuniões, introdutor diplomático, sala do secretário de estado e auxiliares, hall de exposições, chefe da divisão de documentação e sala de pesquisadores, salão de honra, sala dos embaixadores, sala de jantar, sala de almoço, copa, cozinha e vestíbulos. O pavimento era destinado aos escritórios e os seus suportes. Por fim, o segundo andar seria destinado aos salões de cumprimentos, com o grande hall, salão de baile, saleta privativa, vestíbulo do ministro, jardim-terraço, salão de banquetes, com a parte de serviços, como cozinha, copa, frigorífico e quarto-forte. Neste programa, as descrições são mais elaboradas e o segundo pavimento é destinado às recepções.

Por último, o terceiro programa é o mais próximo do projeto final. Nele há quatro pavimentos. O subsolo abriga o auditório, serviços de documentação da divisão de difusão cultural, salas de exposições e reuniões. Esta descrição é semelhante ao que foi executado. Há um entre-solo, com salas de trabalho e cabines para tradutores, rádio e televisão e os acesso para o prédio de representação e administração. Estes espaços foram incorporados ao térreo no projeto final.

A entrada principal está no térreo junto com o jardim de inverno, escadaria de honra, sala de imprensa, salas de oficiais de gabinetes, entrada do auditório, entrada do ministro de Estado com elevador privativo, divisão de difusão cultural e divisão de cooperação intelectual. Retiradas as salas das divisões e incorporado o programa do entre-selo, surge o térreo no projeto executado.

No primeiro andar, teríamos a rampa de acesso e escadaria, o salão nobre, duas antessalas, sala de reunião, salão dos embaixadores, introdutor diplomático, gabinete e sala de repouso do Ministro de Estado, gabinetes, cerimonial e serviço de relações com o congresso. Aqui, o pavimento é destinado aos escritórios e áreas de apoio. Só o espaço para o repouso do ministro foi transformado em apartamento - e encontra-se no térreo. 
O segundo andar, ou terraço, continua dedicado às recepções. Contava com a escadaria de honra, o vestíbulo, salão de baile, pequeno salão, salões de banquetes para 180 pessoas, sala de almoço grande, para 28 , e sala de almoço pequena para 14 pessoa, pequeno salão e área destinada aos serviços de cozinha.

Além dos três programas de necessidades citados, há três plantas e uma perspectiva, sem datação, mas do início de 1960 e provavelmente de um mesmo projeto. Os desenhos não são compatíveis com os programas encontrados. O térreo era formado pelo hall de entrada e portaria, os vestíbulos, um depósito da mapoteca e de livros, salão de leitura e um auditório. A escada era retilínea e há um espaço central em formato quadrado (Figura 9). Os espaços são destinados ao conhecimento e não privilegiam o caminhar pelo ambiente. Na perspectiva (Figura 10) podemos entender melhor o espaço.

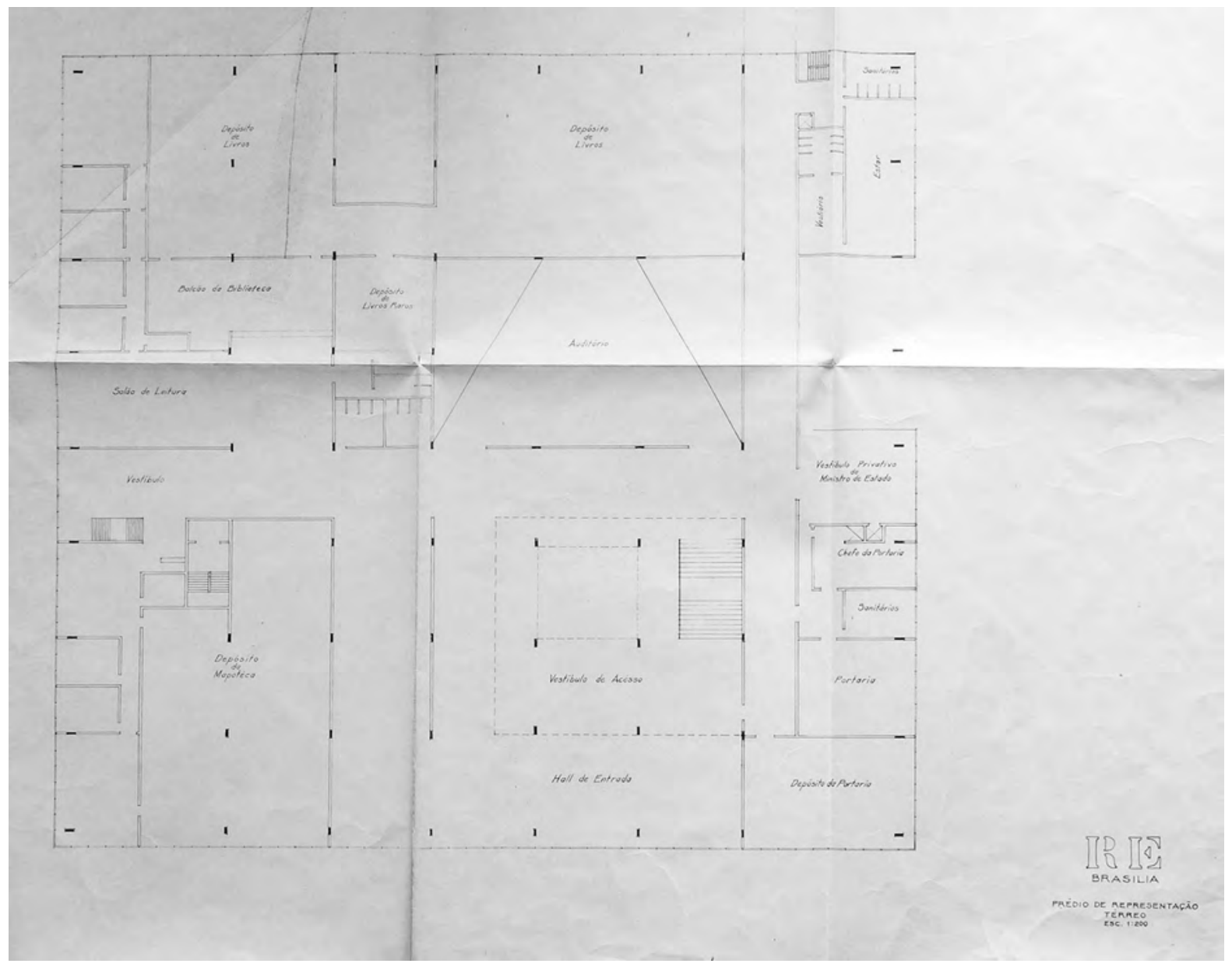


3. A FORMAÇÃO DAS PARTES / 69

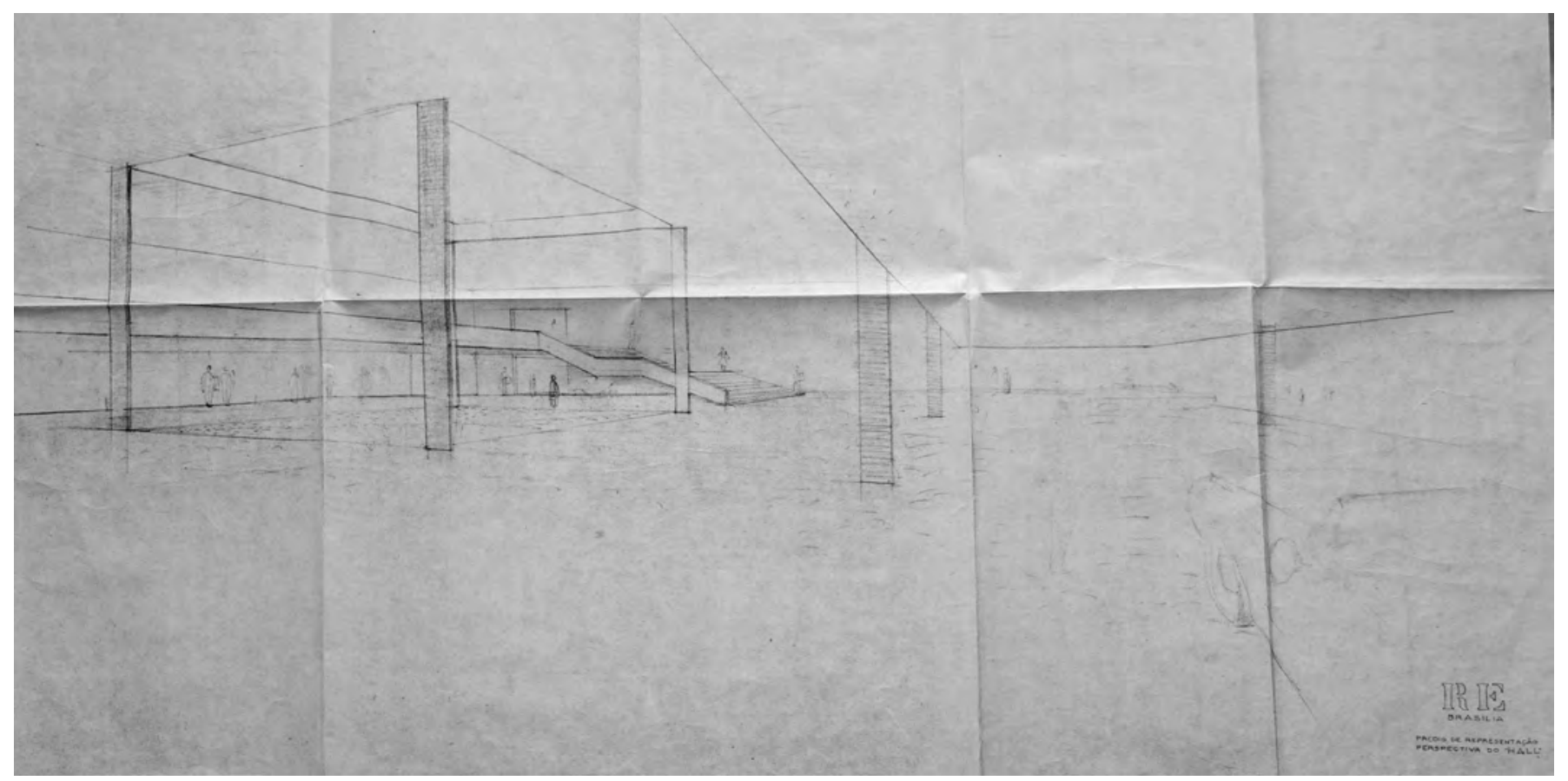

Figura 10: Prédio de Representação - Perspectiva do Hall, datação não identificada. Fonte: SARQ. 
No Primeiro Andar, teríamos todos os gabinetes, sala de jantar e almoço, cozinha, um hall de exposições e ainda um lugar para o depósito dos livros da biblioteca (Figura 11). Já havia o desejo de pensar a planta em três conjuntos dispostos na longitudinal e paralelos.

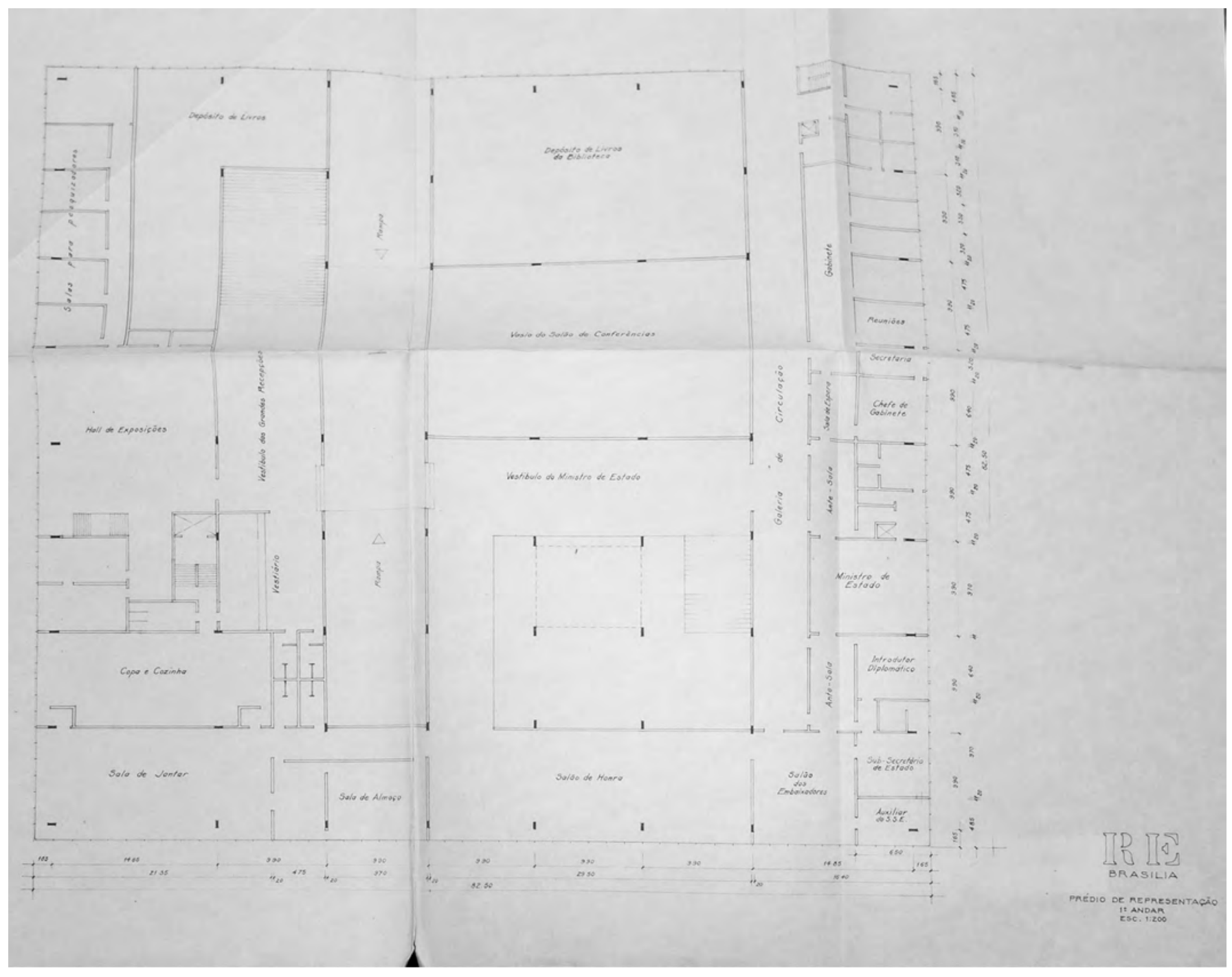

Figura 11: Prédio de Representação - $1^{\circ}$ Andar, datação não identificada. Fonte: SARQ. 
O Segundo Andar era destinado às recepções, com terraço, salão de baile e com o salão de banquete, cozinha e saletas voltadas para o Eixo Monumental (Figura 12). A espacialidade do pavimento já está resolvida, embora alguns ambientes tenham mudado de nome ou uso.

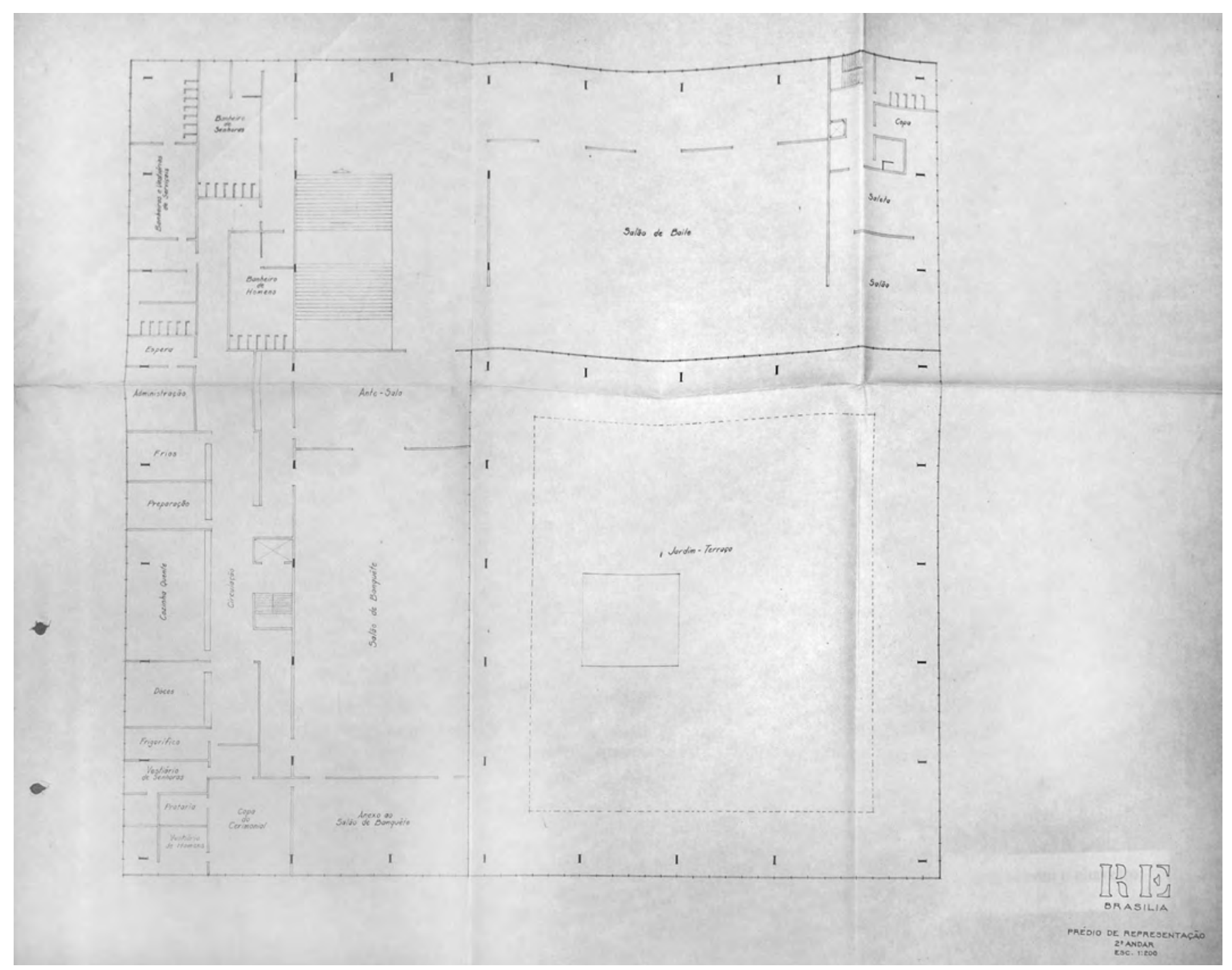

Figura 12: Prédio de Representação - $2^{\circ}$ Andar, datação não identificada. Fonte: SARQ. 
O corte (Figura 13) data de 1960 e mostra a escadaria e o auditório no térreo, confirmando que o conjunto dessas plantas são próximos ao ano de 1960.

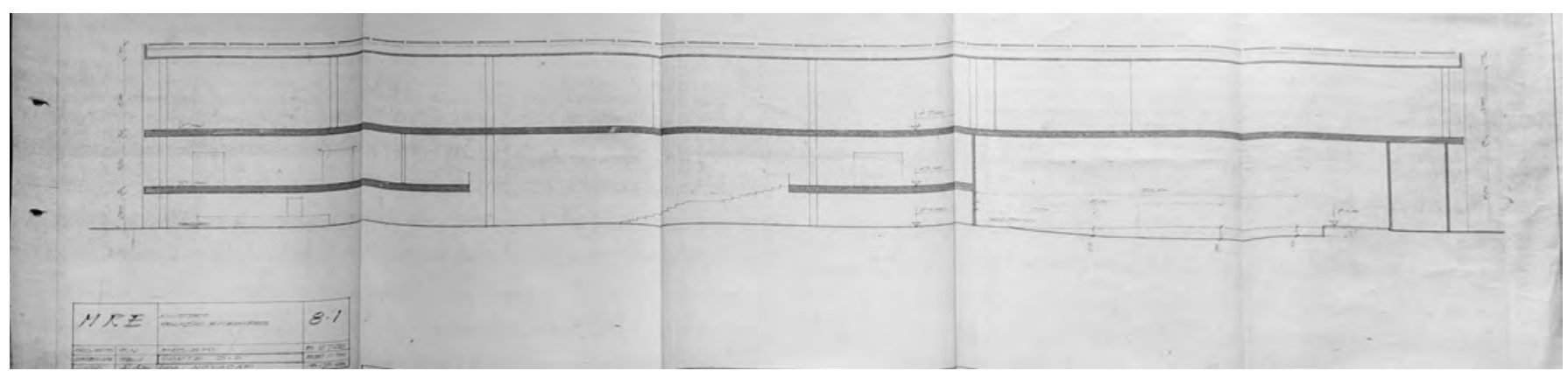

Figura 13: Ministério das Relações Exteriores - Corte D-D, 1960. Fonte: SARQ.

A planta retangular do Palácio Itamaraty no Rio de Janeiro é formada pelo Salão de Baile, Sala de Banquetes (ou Sala dos Índios), Salão de Honra, além dos gabinetes. Salão de Baile, Salas de Banquetes e Salão de Honra são programas que permaneceram no projeto executado da nova sede do Ministério das Relações Exteriores. Nos primeiros projetos e programas, as áreas destinadas ao auditório, biblioteca e mapoteca podem indicar que o edifício da antiga sede carecia de espaços para esses programas ${ }^{34}$. E, por isso, foram incorporados logo no início do projeto. Como Wladimir Murtinho explica no trecho citado no início deste subcapítulo, havia uma preocupação constante dos profissionais do ministério com a circulação de pessoas, pois o edifício representativo recebe as festas oficiais do governo brasileiro, com grande número de convidados. Desejavam que a nova sede do edifício representativo fosse formado por ambientes que possibilitassem esse caminhar desimpedido pelo edifício, por isso a existência de rampas e amplos espaços. Como se mostrou nos programas e projeto iniciais, a solução final foi esboçada entre 1959 a 1964.

De um projeto que partia das ausências do edifício anterior, surge um novo edifício com demandas próprias, sem, evidentemente, excluir algumas das experiências espaciais vivenciadas no antigo edifício, como é o caso do jardim e dos ambientes destinados às recepções. 


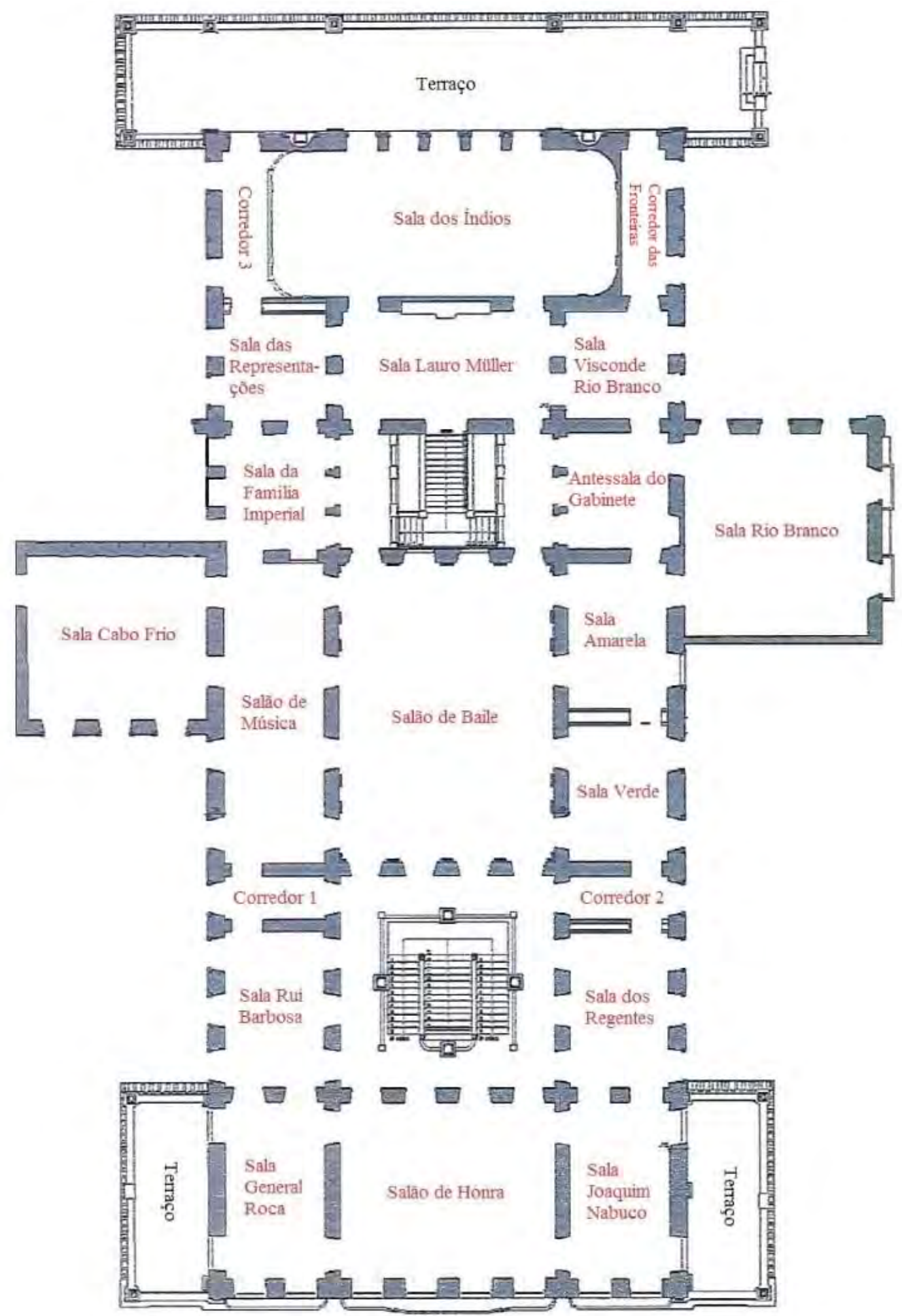

Figura 14: Planta do Segundo Pavimento do Palácio Itamaraty, no Rio de Janeiro, datação não identificada. Fonte: Acervo do Museu Histórico e Diplomático. 


\section{4 os espaços palacianos}

4.1. PRIMEIRA APROXIMAÇÃO IMPLANTAÇÃO E FACHADAS

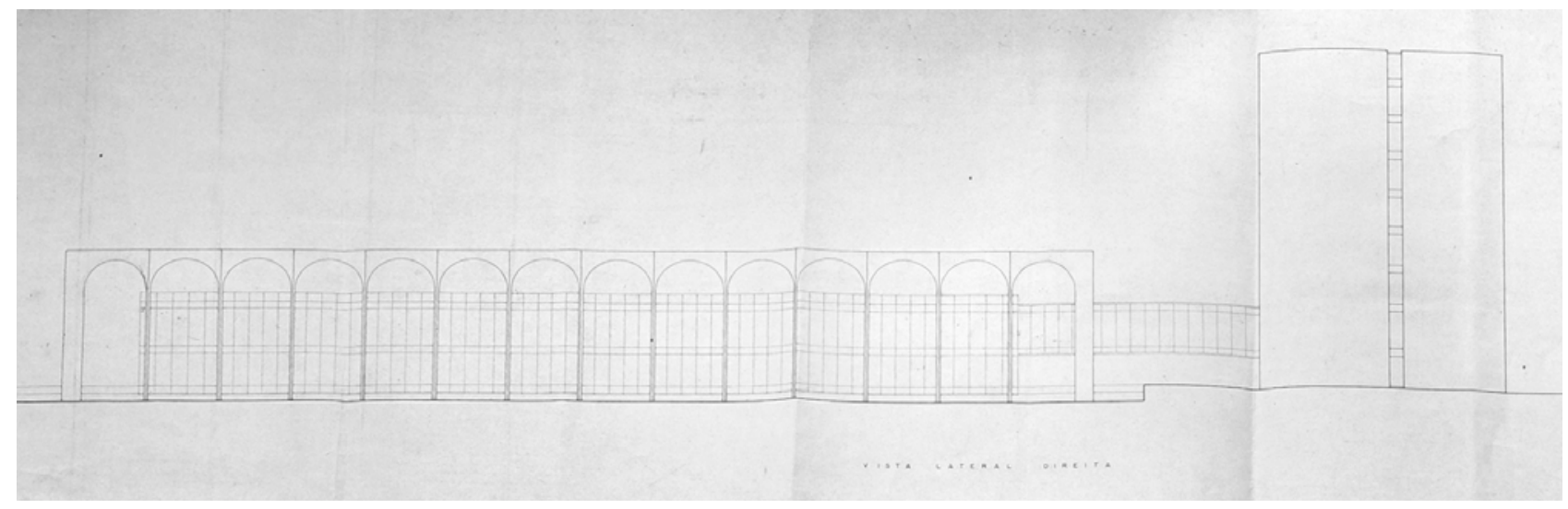

EXTERNA: VISTA LATERAL DIREITA 


\section{"Nós discutimos os}

problemas, eu consegui

convencer o Lúcio Costa de que era lógico que o prédio, o palácio fosse muito grande... Esse palácio porque, eu dizia que se íamos continuar... a ter essa parte de representação era necessário que fosse muito grande"

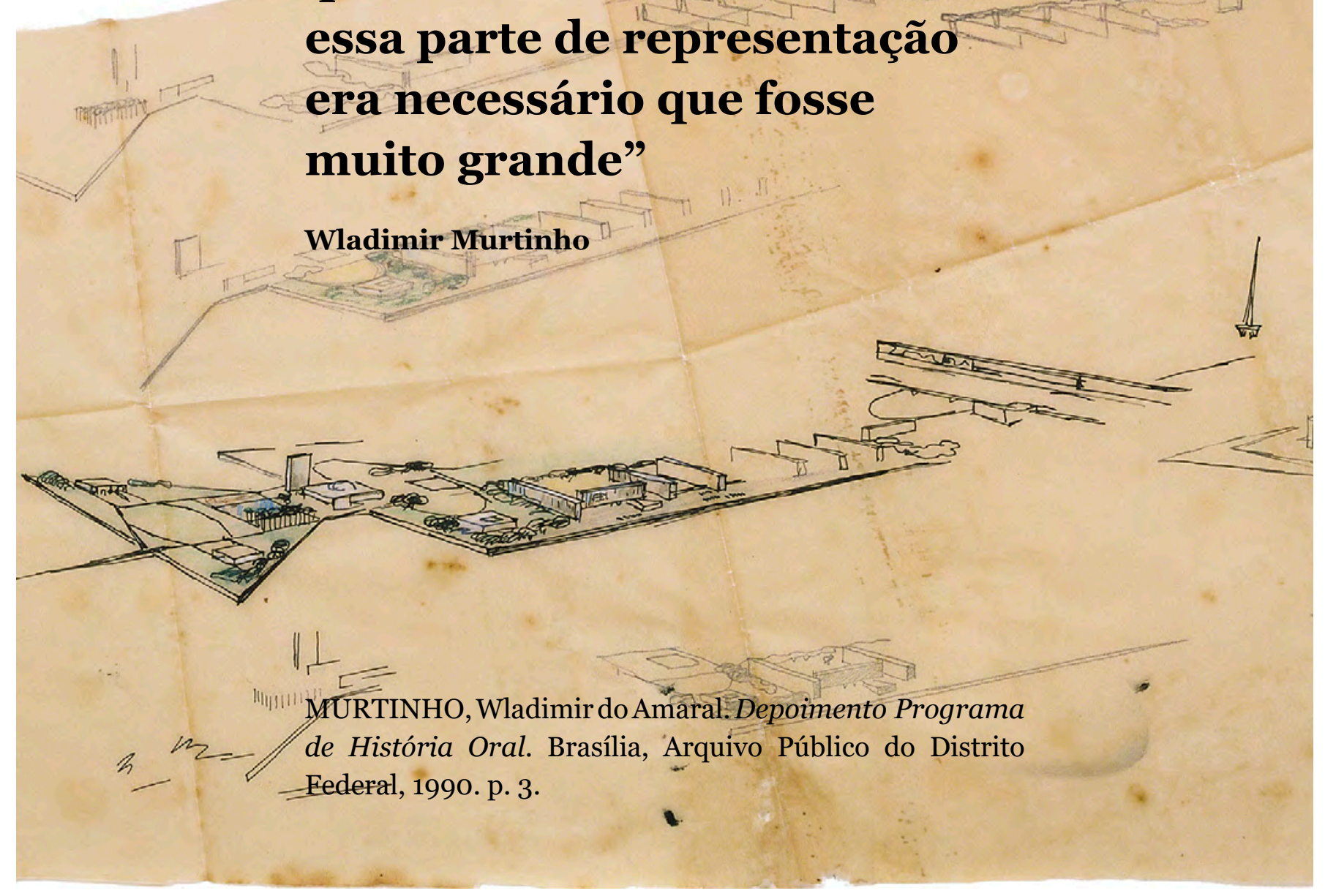

Plano Piloto, datação não identificada. Fonte: Casa de Lúcio Costa. 
Neste esboço do Plano Piloto de Lúcio Costa, os ministérios tem a mesma tipologia formal - uma lâmina - já que fazem parte de um mesmo conjunto funcional. No entanto, entre os ministérios e o Congresso, já se observa o desenho de um prisma vazado e de duas lâminas no mesmo sentido dos ministérios, intercaladas por uma lâmina a 90 graus, o que indica que haveria uma transição visual entre o Congresso e os ministérios, conforme o próprio Wladimir Murtinho conta:

Veja bem, a ideia era colocar um prédio pequeno interligado com o que é hoje o Ministério da Saúde. Esse foi o primeiro projeto. E ele era mínimo. E o motivo que era mínimo, porque o Lúcio Costa julgava que o volume... dos palácios, tanto do Ministério das Relações Exteriores como do Palácio do Ministério do Interior, porque seria isso, exterior e interior, não é? O daquela época, a ideia do interior era o Ministério da Justiça. Ministério do Interior. É, seriam pequenos para não atrapalhar, a imponência do Congresso e o acesso à Praça dos Três Poderes. De maneira que a ideia deles, era um palácio muitíssimo menor do que este. (...) Esse prédio, depois teve uma variante, cresceu um pouquinho, e foi só depois que se decidiu, definitivamente fazendo o atual, quando nós ponderamos que não cabia. Ou seja, o que aconteceu é que eles estavam visualizando um problema urbanístico, não tirar a dramaticidade da Praça dos Três Poderes. (MURTINHO, 1990, p. 17)

O Embaixador Wladimir Murtinho convence Lúcio Costa sobre a necessidade de se ter um "grande palácio" para abrigar as funções representativas do Ministério das Relações Exteriores e, por consequência, do governo brasileiro. A Figura 15, provavelmente de 1960, mostra o pequeno edifício representativo em forma de um quadrilátero ligado ao edifício administrativo. 
4. OS ESPAÇOS PALACIANOS / 77

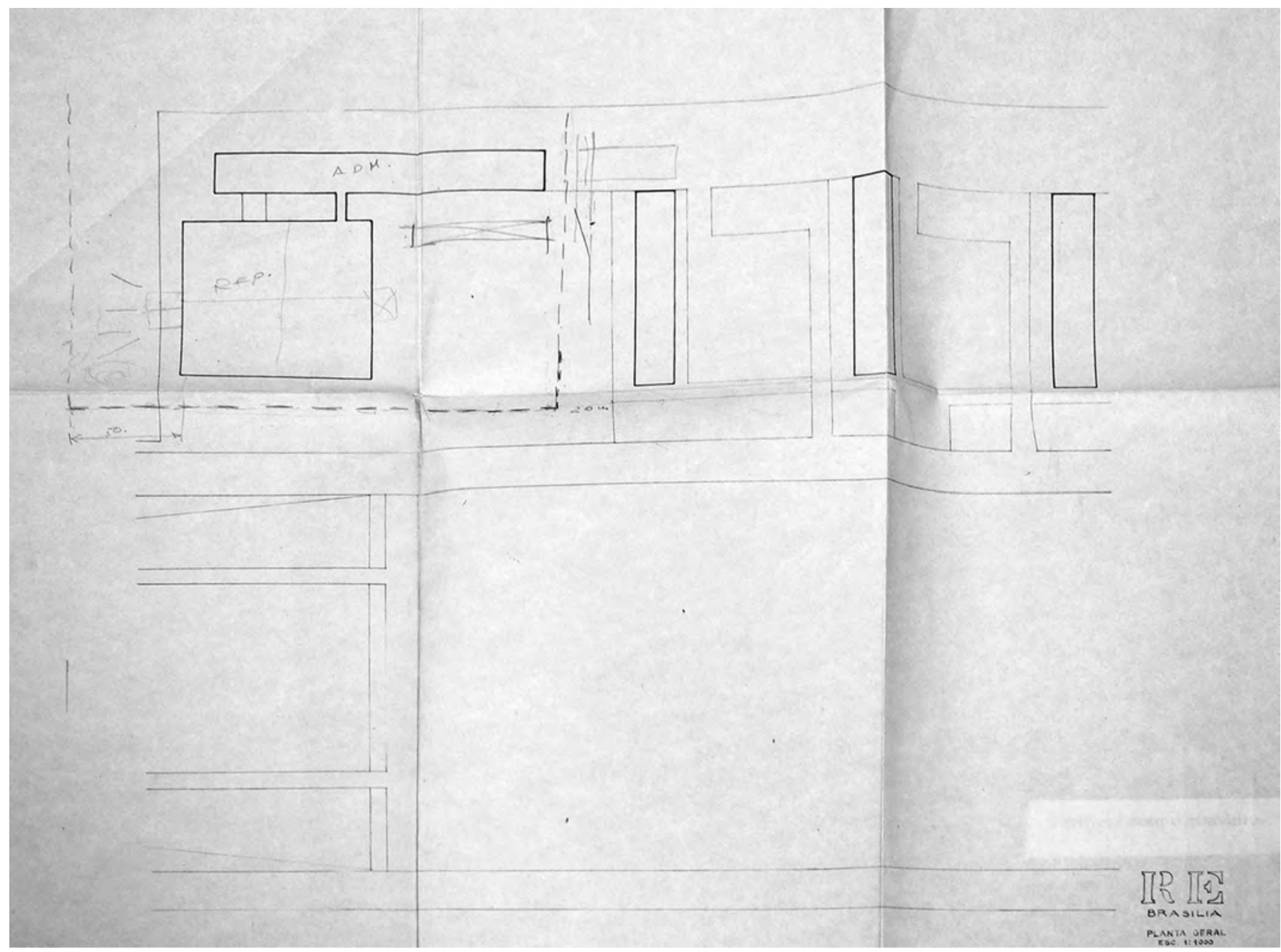

Figura 15: Planta geral, datação não identificada. Fonte: SARQ. 
Jayme Maurício escreveu “Palácio Rio Branco, Brasília”, matéria publicada na Revista Habitat n. 52, em janeiro de 1959. O jornalista aponta que o edifício administrativo seria um dos edifícios padronizados dos ministérios. Ligado por um passadiço ao bloco administrativo, o prédio representativo seria formado por dois andares e um jardim suspenso. A circulação seria feita por rampas e escadas. O eixo principal deste projeto é o terraço com o jardim e as rampas, além da planta em formato quadrado para o edifício representativo.

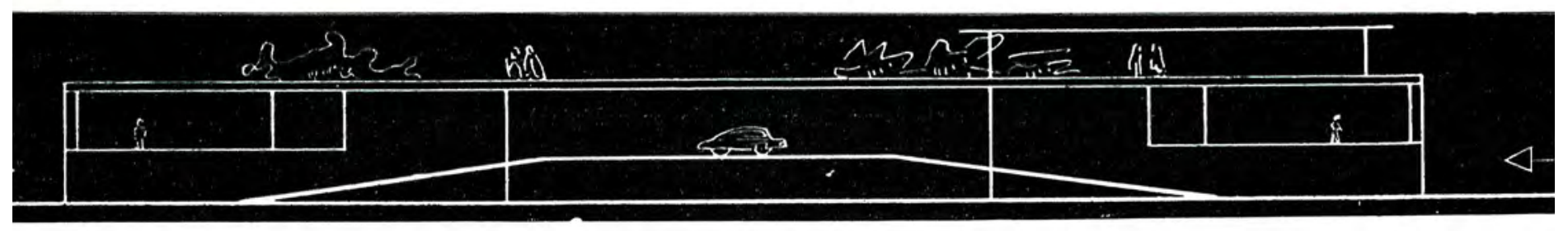

Figura 16: Corte esquemático de um dos projetos iniciais para o Ministério das Relações Exteriores. Fonte: Revista Habitat n 52, 1959.

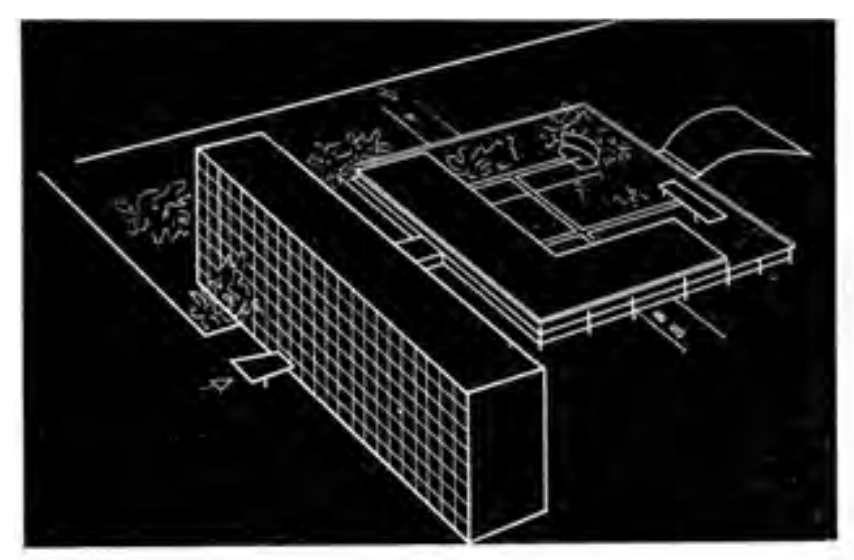

Figura 17: Perspectiva de um dos projetos iniciais para o Ministério das Relações Exteriores. Fonte: Revista Habitat n 52, 1959. 
O desenho da rampa já estava esboçado em 1960. Esta rampa cruza o palácio do Eixo Monumental ao edifício anexo. É destinada ao uso do carro oficial do Ministro de Estado. O embarque e desembarque dentro do palácio ocorre no primeiro andar.

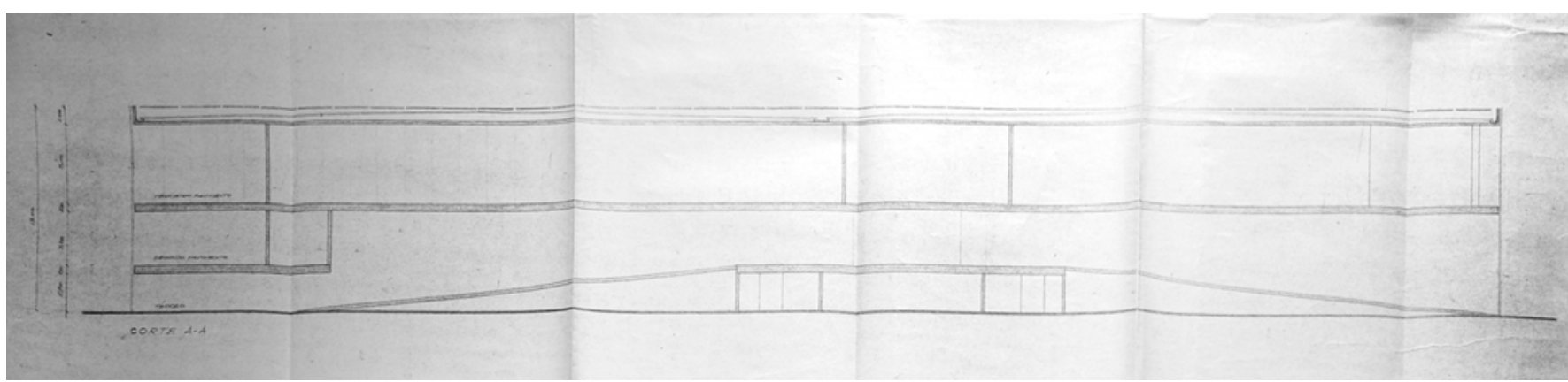

Figura 18: Corte A-A, Novacap, 1960. Fonte: SARQ.

Ainda em 1959, a revista L'Architecture d'Aujourd'Hui n ${ }^{\circ} 90$ e a Revista Brasília ${ }^{0} 30$ publicam a fotografia de uma maquete do ministério. Observase a presença de uma lâmina, provavelmente o edifício administrativo, com 5 pavimentos. Também há um edifício de ministério tipo, o atual Ministério da Saúde. Ao lado, um volume baixo, de planta quadrada com fechamento de vidro recuado do plano da fachada, que é formado por finas colunas equidistantes entre si, sem expressividade plástica. Há duas aberturas próximas à cobertura, já demonstrando um desejo de soltar a parte superior do edifício.

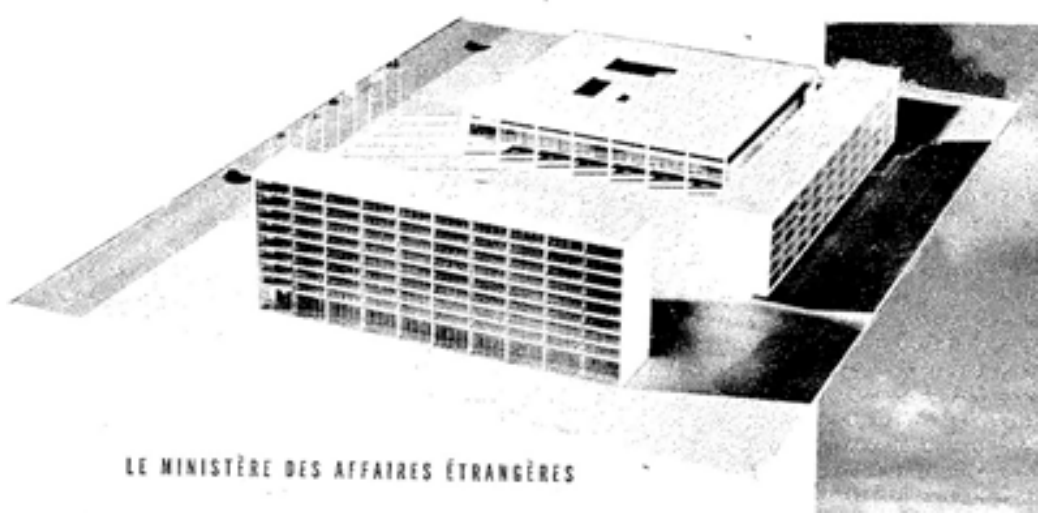


Entre 1961 e 1962, a elaboração do projeto ficou parada. Somente em 1963 com a assinatura do contrato com Construtora Pederneiras ${ }^{35}$, responsável pela execução das obras, que o projeto começa a ganhar mais contornos. Até agora as colunas não tinham expressividade, a partir deste momento começam a ganhar seus arcos, claramente uma referência à fachada neoclássica da antiga sede do Ministério das Relações Exteriores, no Rio de Janeiro.

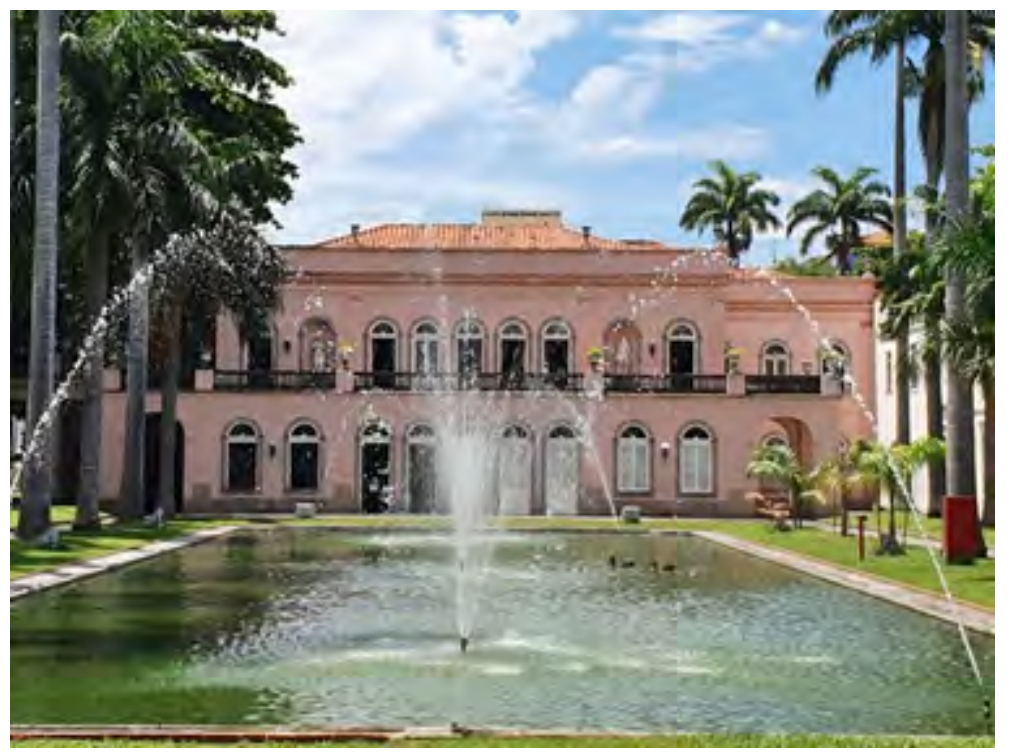

Figura 20: Palácio Itamaraty, Rio de Janeiro. Fonte: Karen Matsuda, 2020.

Em agosto de 1963, a estrutura com 4 pavimentos tal como conhecemos já está definida, bem como o desenho da fachada: uma caixa de vidro simétrica delimitada por pilares de base triangular. $\mathrm{O}$ clássico do edifício encontrase nas arcadas equidistantes e na simetria. Arcadas fazem parte de uma gramática clássica, muito bem conhecida pelos europeus e hispânicos na prática projetual. Não por acaso, a crítica literária de Buenos Aires, Beatriz Sarlo, escreve sobre sua primeira viagem à Brasília, nos anos 1960:

O Itamaraty, ao contrário, podia mudar de mãos, de um regime político a outro. Contornávamos o espelho-d'água em que se apoiam as colunas. Estávamos contentes porque o reconhecimento daquele peristilo retangular, em meio a tamanho vendaval de novidades, suscita prazer até em quem, como nós, procurava ser surpreendido o tempo todo. (SARLO, 2012) 
4. OS ESPAÇOS PALACIANOS / 81

Assim, pela maquete de 1964 (Figura 21), a solução das arcadas, a abertura no terraço e o edifício anexo já estão definidos.

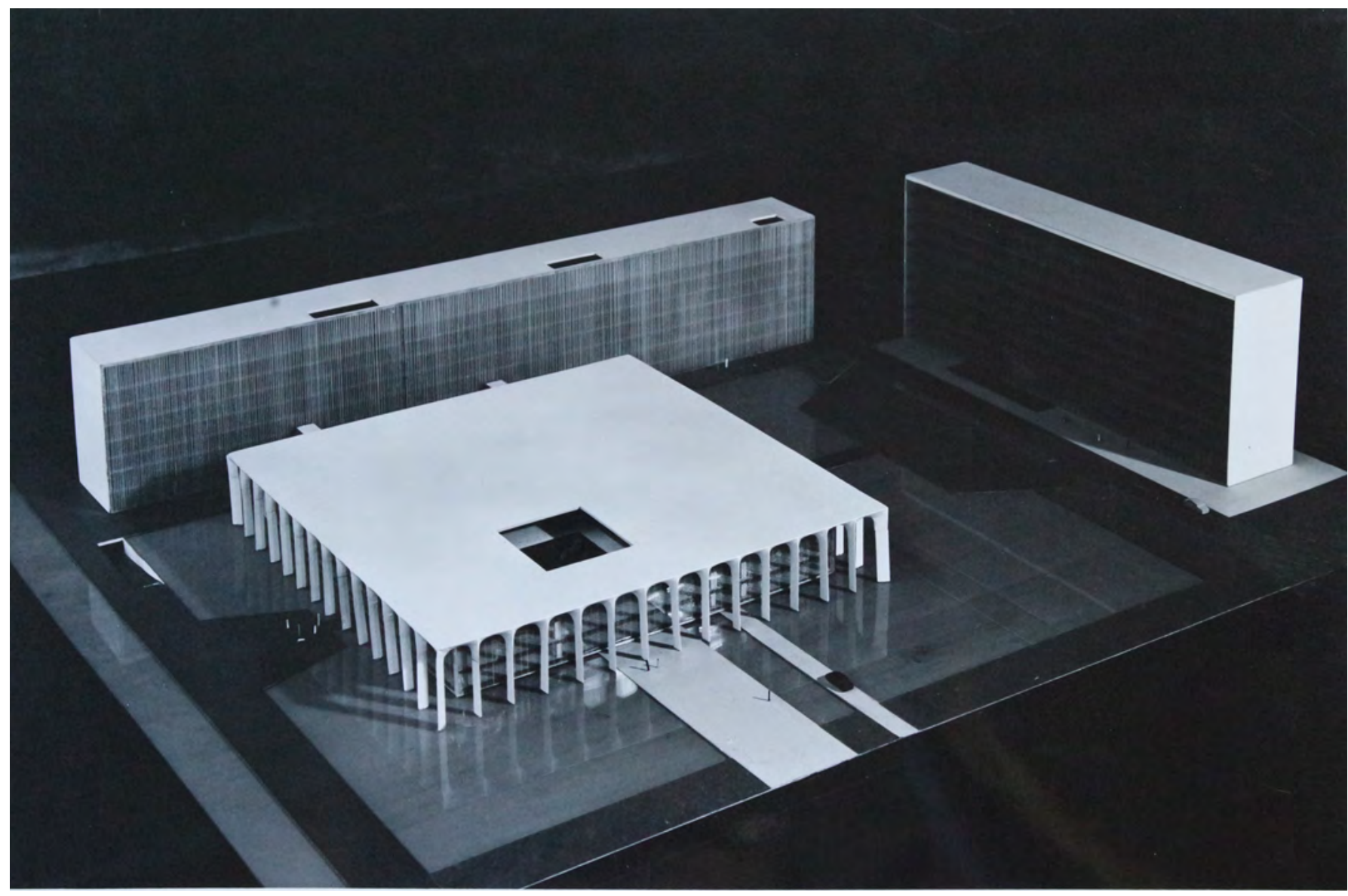

Figura 21: Maquete do Palácio Itamaraty, Milton Ramos, datação não identificada. Fonte: Acervo Arquiteto MR.

Esta fotografia (Figura 21) foi publicada no jornal Correio Braziliense, na matéria "Itamarati já tem "maquete", em que se dizia :

O conjunto arquitetônico é formado por dois prédios distintos: um longo, com oito pavimentos, destinado aos trabalhos administrativos, outro baixo, quadrangular, com um novo tipo de coluna e que se destina a recepções, cerimonial e solenidades importantes. Fica ilhada por um espelho d'água, com uma entrada principal. ${ }^{36}$ 
O edifício ao lado, que não é mencionado na reportagem, é o atual Ministério da Saúde. Também em março de 1964, as fundações do edifício estavam prontas.

No Palácio Itamaraty, o arquiteto Milton Ramos estudou a fachada do edifício $^{37}$. A começar pela base triangular isósceles, responsável pelo pilar esbelto. A secção do pilar foi concretada com seixo rolado, e não com brita, como era o costume, para que a espessura desejada fosse viável.

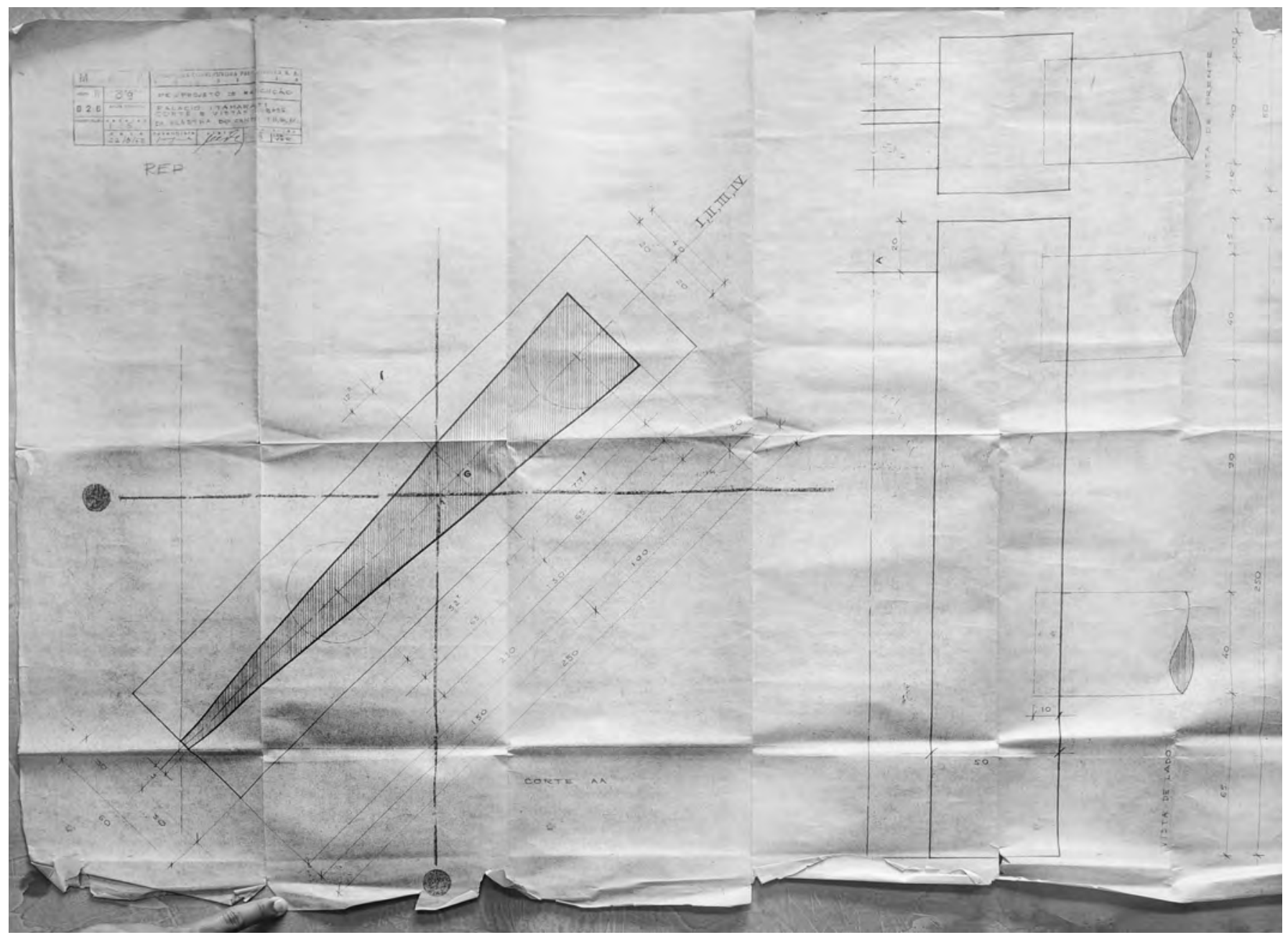

Figura 22: Palácio Itamarati Corte e vistas base da pilastra do canto I, II, III, IV, 1963. Fonte: SARQ.

37 Para mais informações sobre as questões da obra, ver a entrevista de Milton Ramos no Instituto de Arquitetos do Brasil (IAB-DF), em 1966. 
4. OS ESPAÇOS PALACIANOS / 83

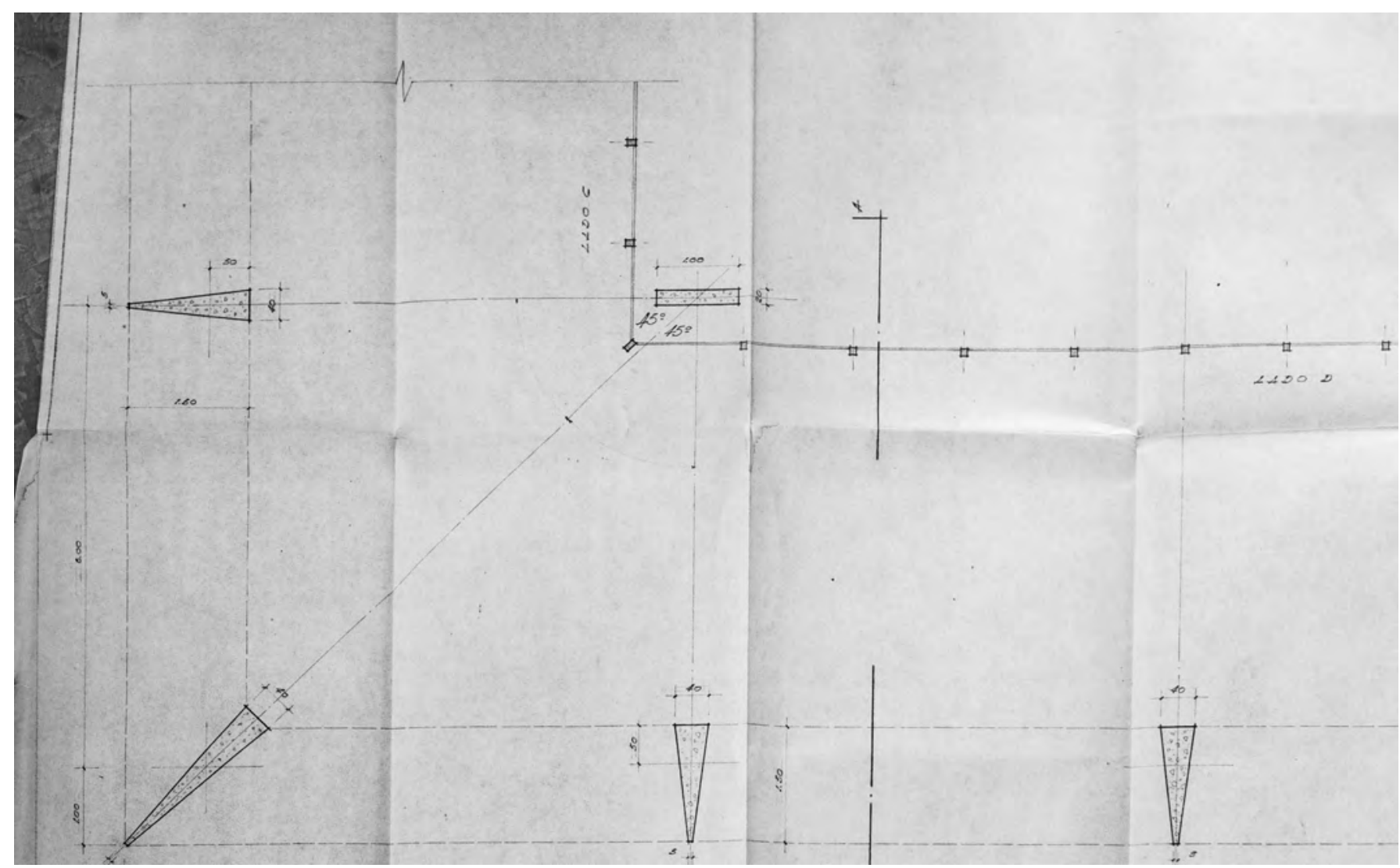

Figura 23: Colunas Perimetrais, 1964. Fonte: SARQ.
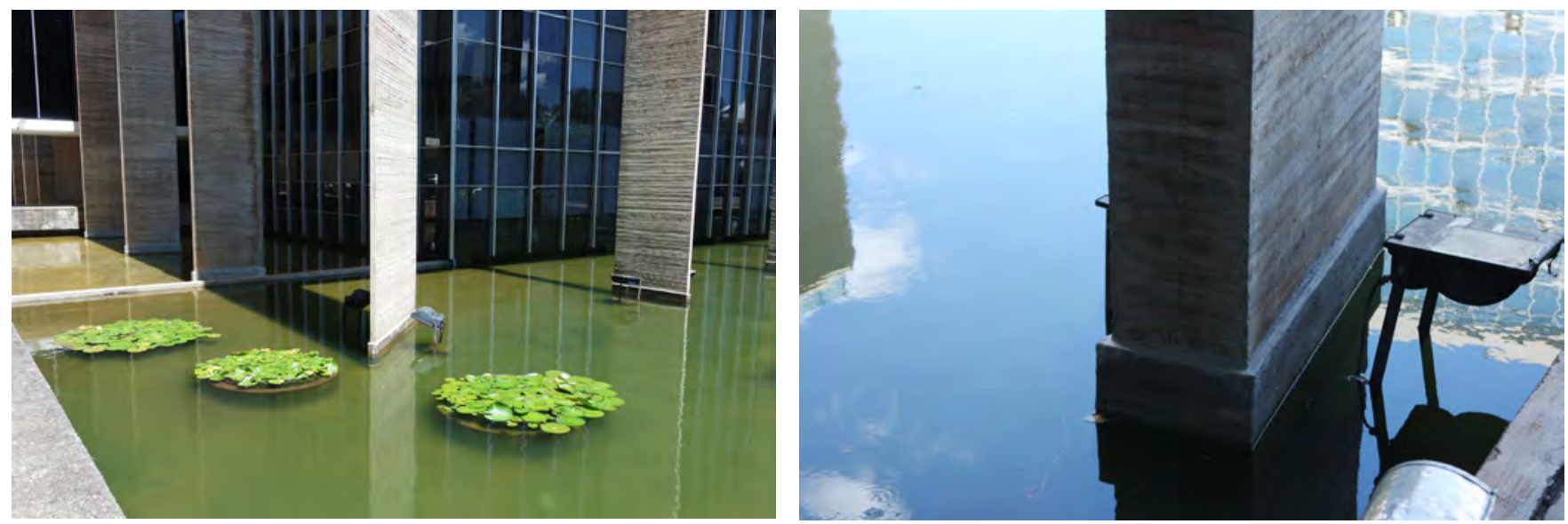

Figura 24: Fotografia do pilar. Fonte: Karen Matsuda, 2019.

Figura 25: Fotografia do pilar. Fonte: Karen Matsuda, 2019. 
Para dar o acabamento característico no concreto aparente de cor ocre, Milton Ramos utilizou estreitas ripas de madeira trapezoidais nas fôrmas que acompanharam o desenho dos pilares e dos arcos, sendo possível repetir a utilização desse recurso por todo o palácio de modo que o acabamento ficasse sem emendas aparentes no concreto. A solução de acabamento das colunatas deve-se à plasticidade do concreto.

Todos os arcos intermediários são arcos plenos. Mas, nas extremidades, Milton Ramos alterou a posição da tangente para mais embaixo, diminuindo o tamanho dos arcos, a fim de corrigir o desvio do olho na perspectiva, do contrário, as pilastras externas dariam a sensação de abertura. Foi feito um modelo de 1:1 para estudar as arcadas e seu acabamento com as ripas.

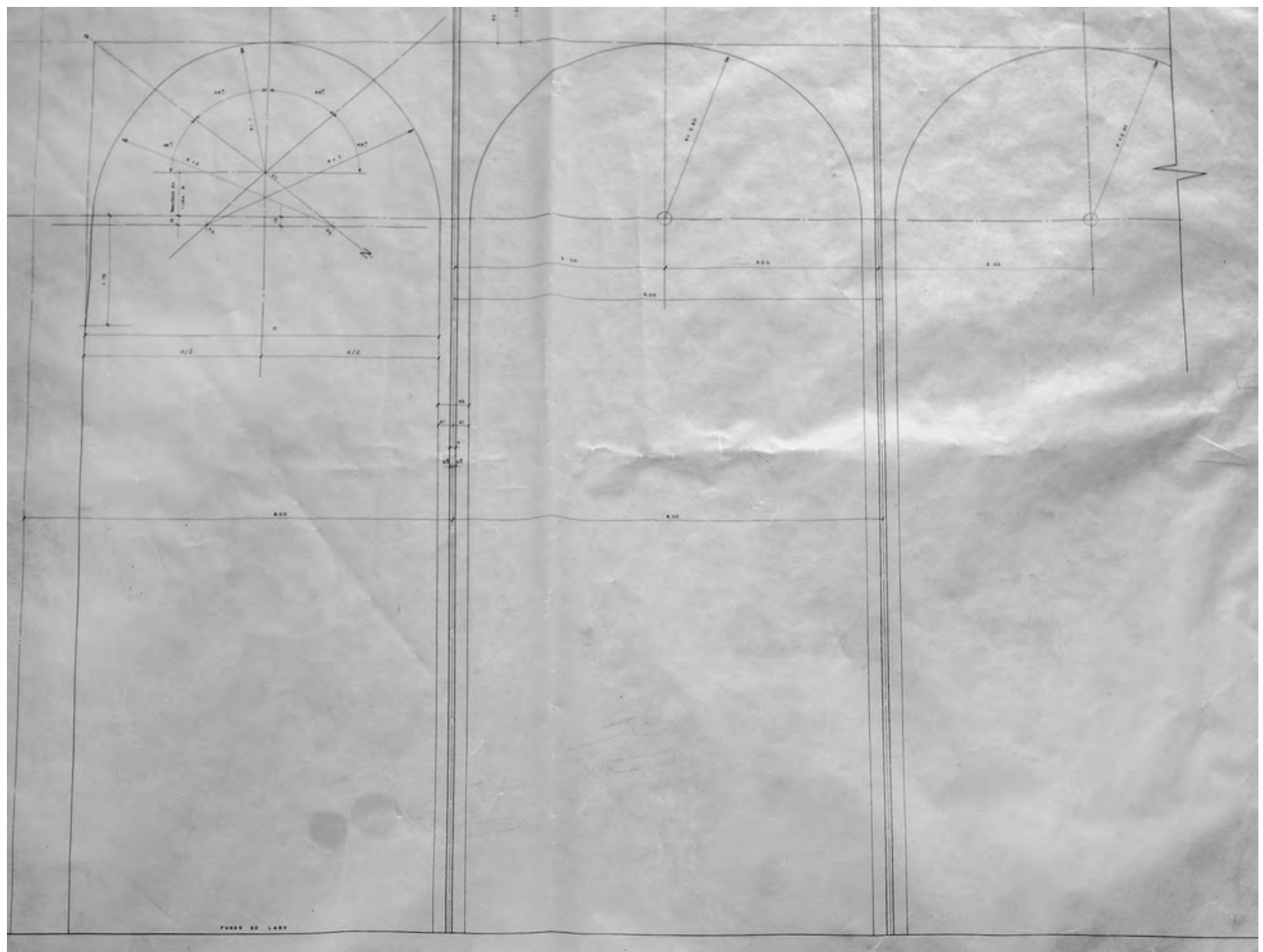

Figura 26: Detalhe construtivo das pilastras e arcadas, 1965. Fonte: SARQ. 
Por fim, a incidência da luz solar foi estudada. Na fachada, a luz solar faz "vibrar" as colunatas de um modo mais intenso ou mais suave, devido a existência da marca das ripas. Conforme as fotografias (Figura 28, Figura 29 e Figura 30) mostram.

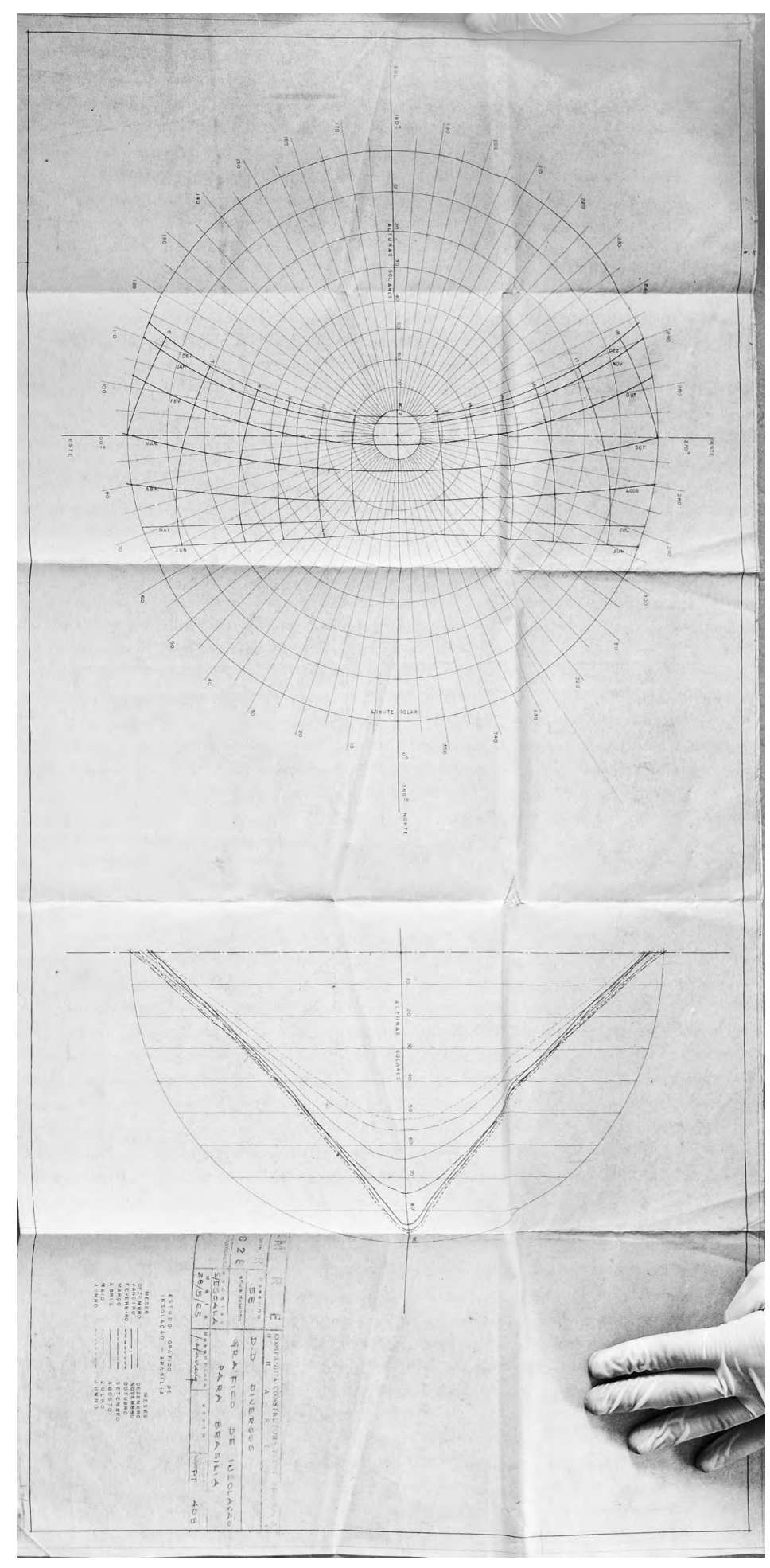

Figura 27: Gráfico de insolação para Brasília, 1965. Fonte: SARQ. 

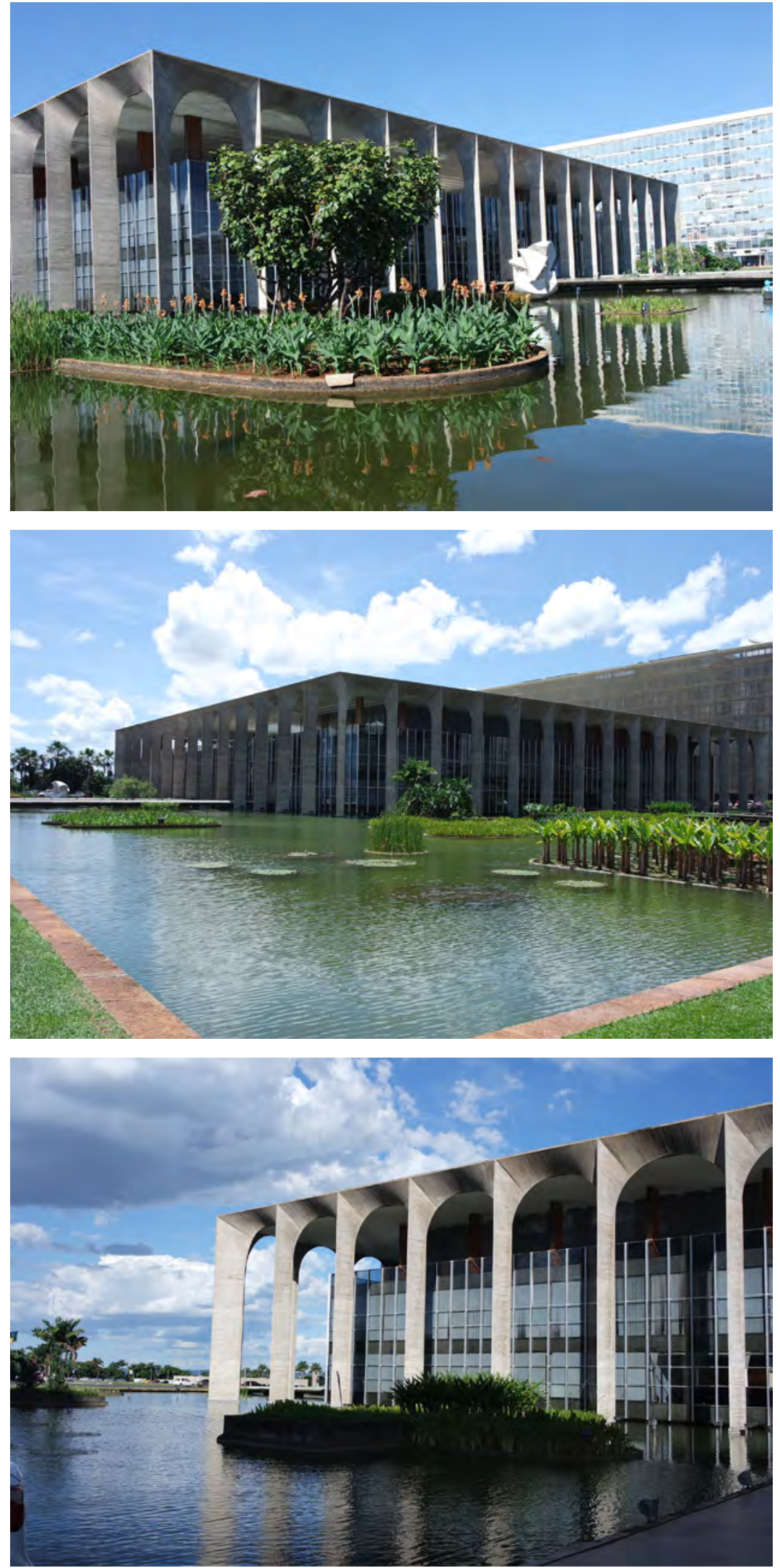

Figura 28: Palácio Itamaraty, fotografia tirada às 8h46, em janeiro de 2019. Fonte: Karen Matsuda. Figura 29: Palácio Itamaraty, fotografia tirada às 14h50, em janeiro de 2019. Fonte: Karen Matsuda. Figura 30: Palácio Itamaraty, fotografia tirada às 16h54, em janeiro de 2019. Fonte: Karen Matsuda. 
4. OS ESPAÇOS PALACIANOS / 87

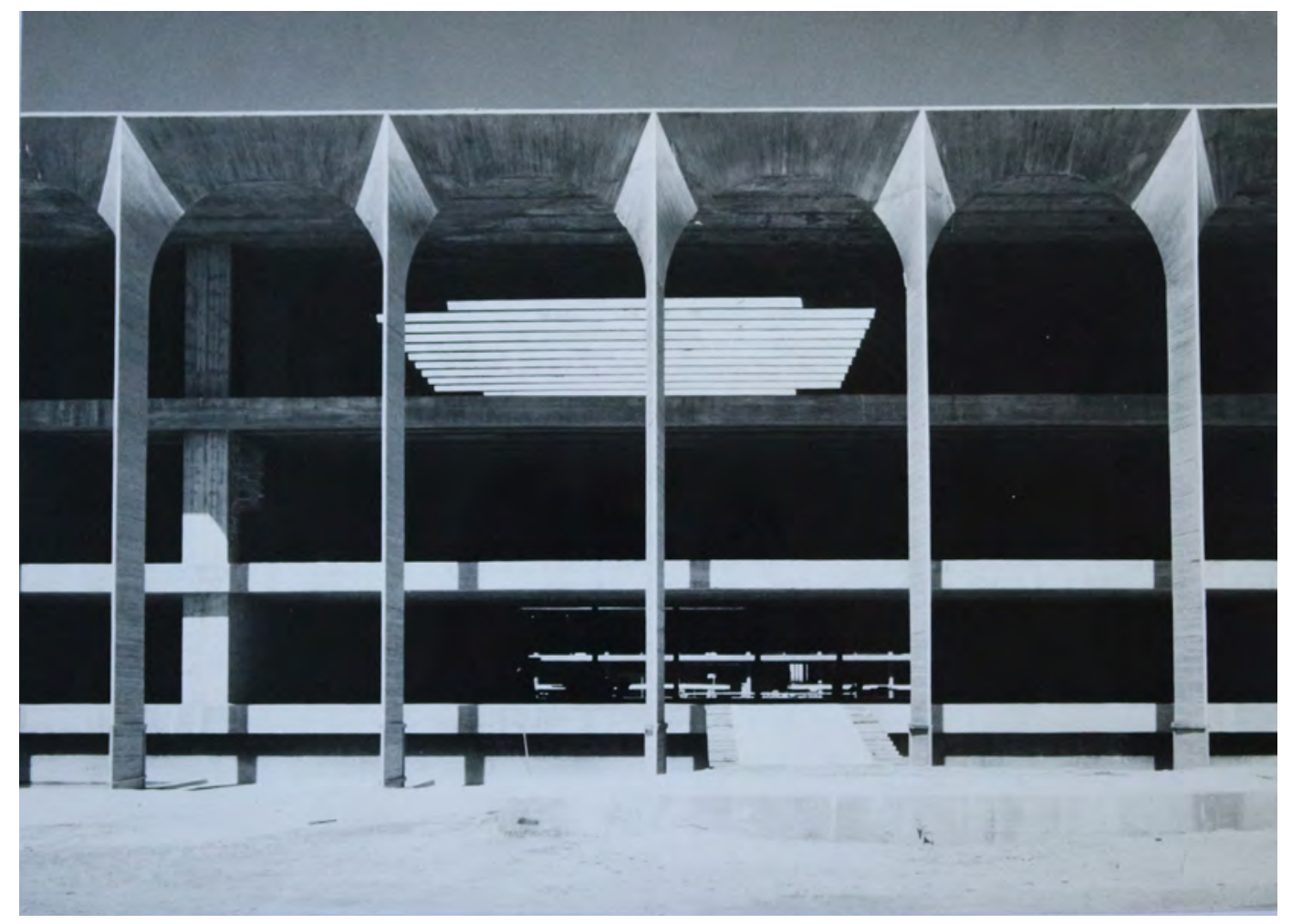

Figura 31: Palácio Itamaraty, Milton Ramos, datação não identificada. Fonte: Acervo Arquiteto MR. 


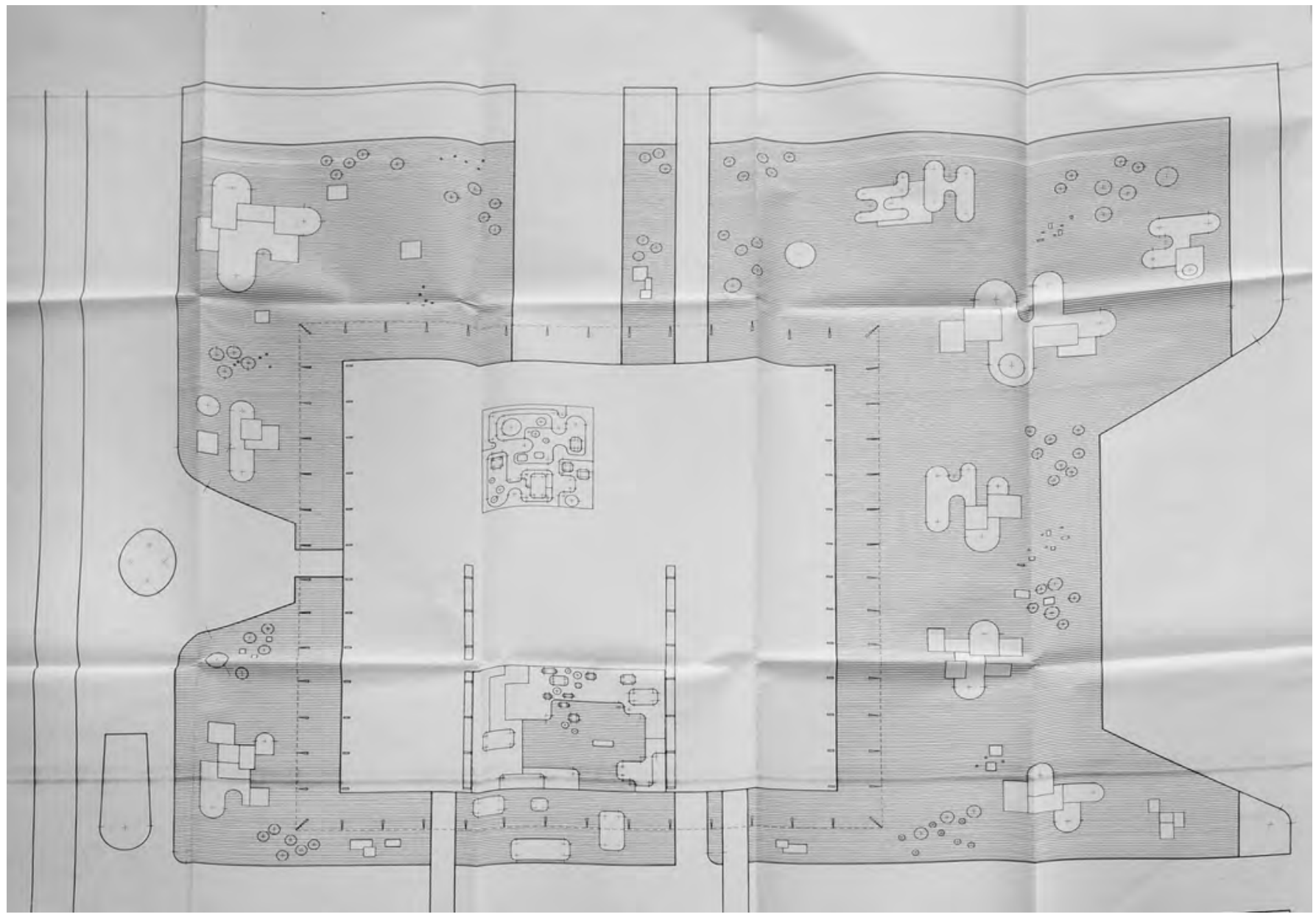

Figura 32: Paisagismo, Roberto Burle Marx, 1966. Fonte: SARQ.

O paisagismo foi elaborado por Burle Marx entre 1965 e 1966 e teve sua execução no início de 1967. Um importante projeto em sua trajetória, como conta o paisagista:

Ontem, vim de Brasília, onde terminei o jardim do MRE. É um jardim que, na minha carreira, tem uma importância enorme. É um jardim aquático, no qual há um grande número de plantas da região. A solução como jardim aquático é nova, sobretudo se estabeleço um paralelo com o jardim aquático de Casa Forte, em Pernambuco, meu primeiro jardim aquático. Os volumes distribuídos no lago ou tanque que circunda o MRE estão ligados ao ritmo dos arcos que caracteriza o prédio. Naturalmente, este jardim só vai mostrar as intenções depois que as plantas crescerem. O jardim interno se liga ao jardim externo. Cobri tubos com xaxim e plantei filodendros, antúrios e outras plantas epífitas. É verdade que o efeito é de primeira qualidade e Oscar Niemeyer gostou muito. (DOURADO, 2014, p. 220) 
O jardim aquático contorna todo o palácio. Quatro passarelas levam às entradas do prédio, sendo duas laterais - uma para o Ministro e outro para o público geral - e duas no Eixo Monumental - uma para a entrada de veículos e outra para os convidados. Segundo Manuel Mendes:

A respeito desse espelho d'água, que dá toda a beleza ao Palácio, realçando a majestade de seus arcos, recordo um fato singular: não constava do projeto original de Niemeyer. Surgiu de observações feitas pelo Ministro Murtinho e pelo arquiteto do Itamaraty, Olavo Redig de Campos, quanto a medidas de segurança próprias de uma Chancelaria. A ideia original era de um jardim contínuo, rodeando todo o edifício até as colunas. Ocorre que, por motivos de segurança, as entradas e saídas de qualquer Ministério das Relações Exteriores são objeto de especial planejamento. (MENDES, 1995, p. 61)

A forma do contorno é sinuosa. O paisagismo é formado por conjuntos de bases de canteiros em formato prismático e circular localizados dentro do espelho d'água. Nestes conjuntos, há uma relação interna entre o volume, textura e altura das plantas utilizadas. Há também conjuntos de vitória régias ao longo do espelho d'água, em canteiros mais baixos, que ficam submersos no espelho d'água.

Também 36 buritis - palmeira que alcança 30 metros de altura, sendo muito comum no cerrado brasileiro - foram colocados ao lado leste, pelo Departamento de Plantas e Jardins, em decorrência da visita da rainha Elizabeth II, conforme a reportagem "Os velhos Buritis", de Manuel Mendes, em 27 de outubro de 1968. 


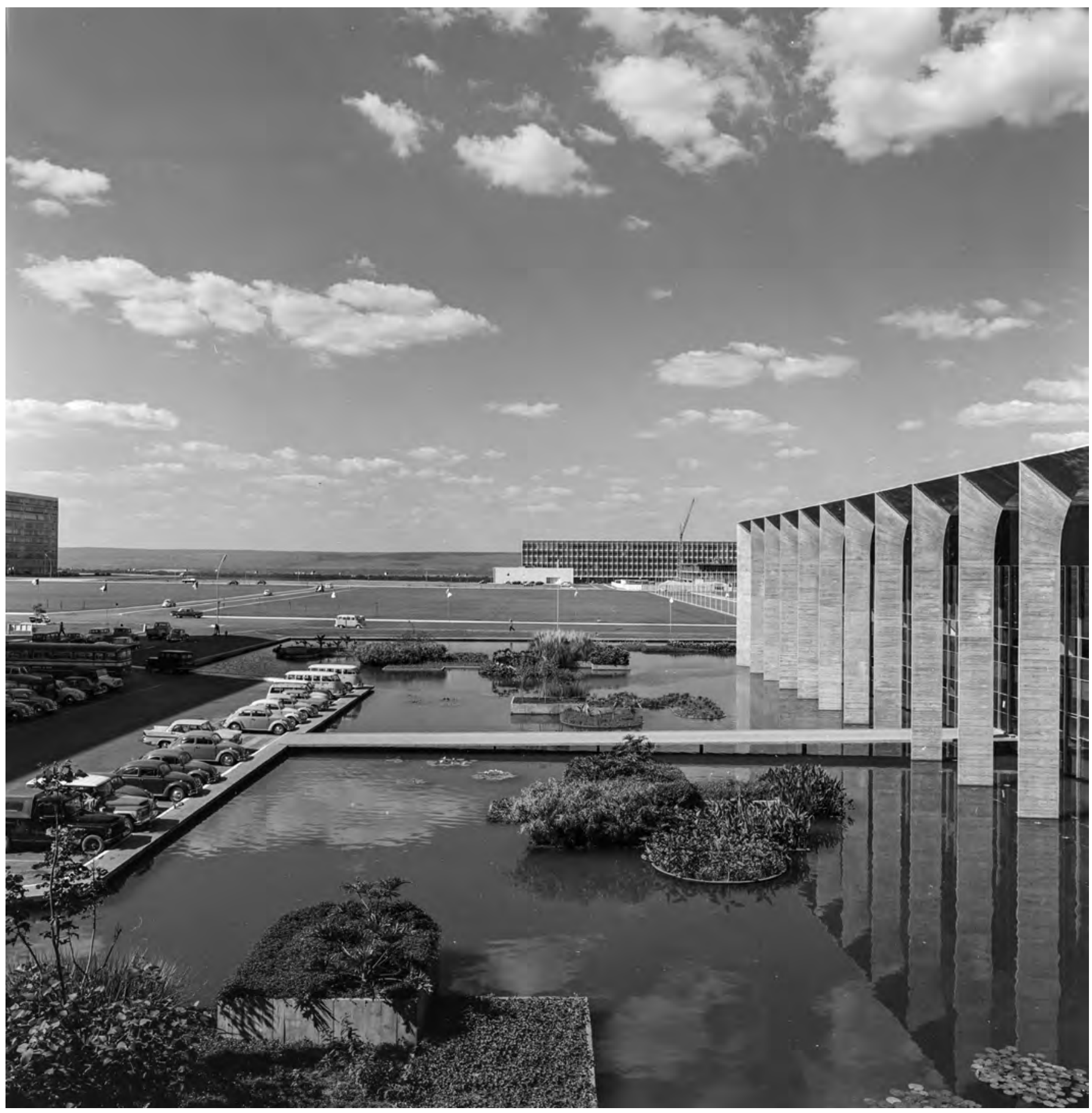

Figura 33: Palácio Itamaraty, Marcel Gautherot, 1968. Fonte: Instituto Moreira Salles. 
4. OS ESPAÇOS PALACIANOS / 91

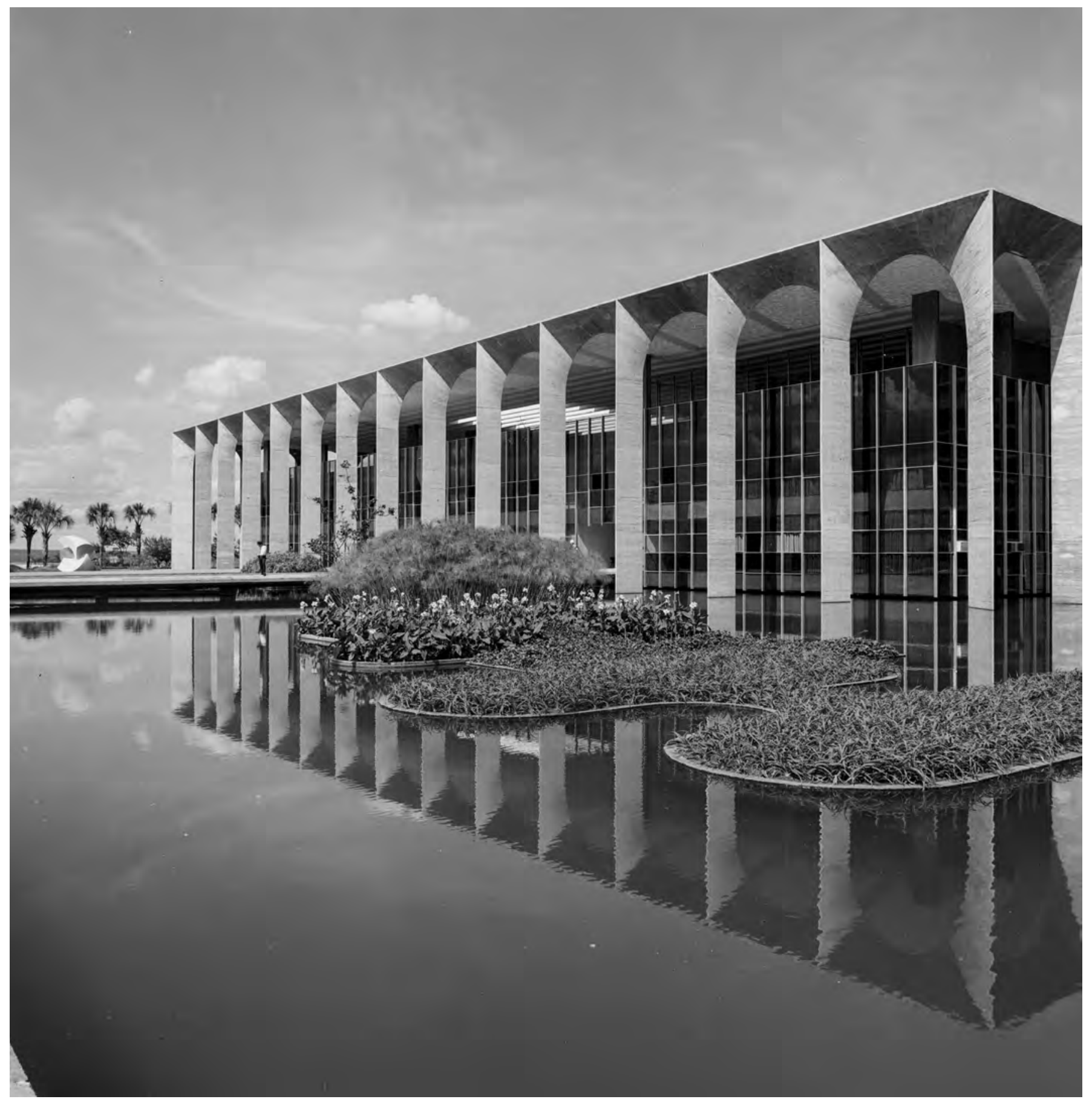

Figura 34: Palácio Itamaraty, Marcel Gautherot, c.a. 1970. Fonte: Instituto Moreira Salles. 


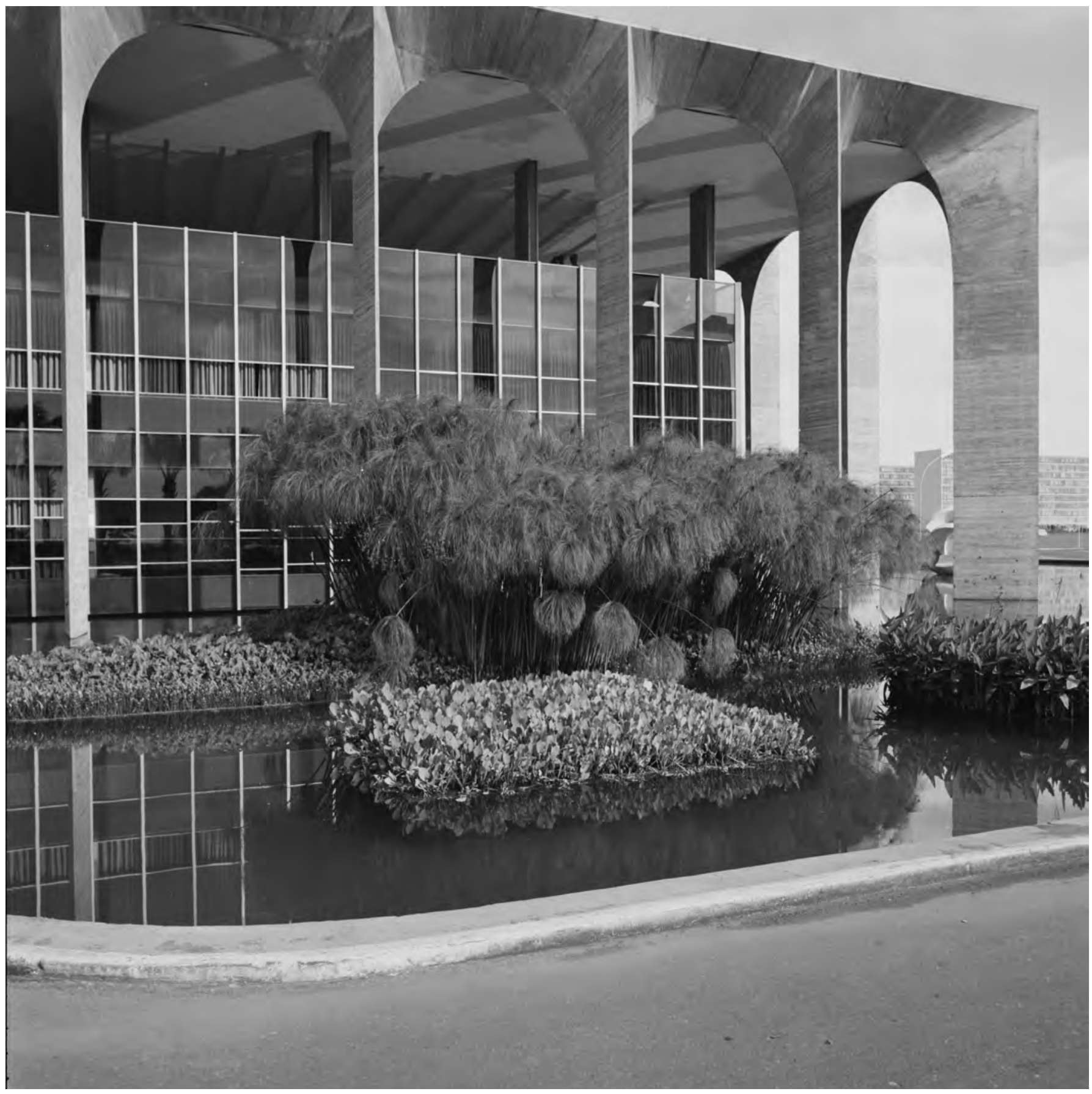

Figura 35: Palácio Itamaraty, Marcel Gautherot, 1968. Fonte: Instituto Moreira Salles. 
4. OS ESPAÇOS PALACIANOS / 93

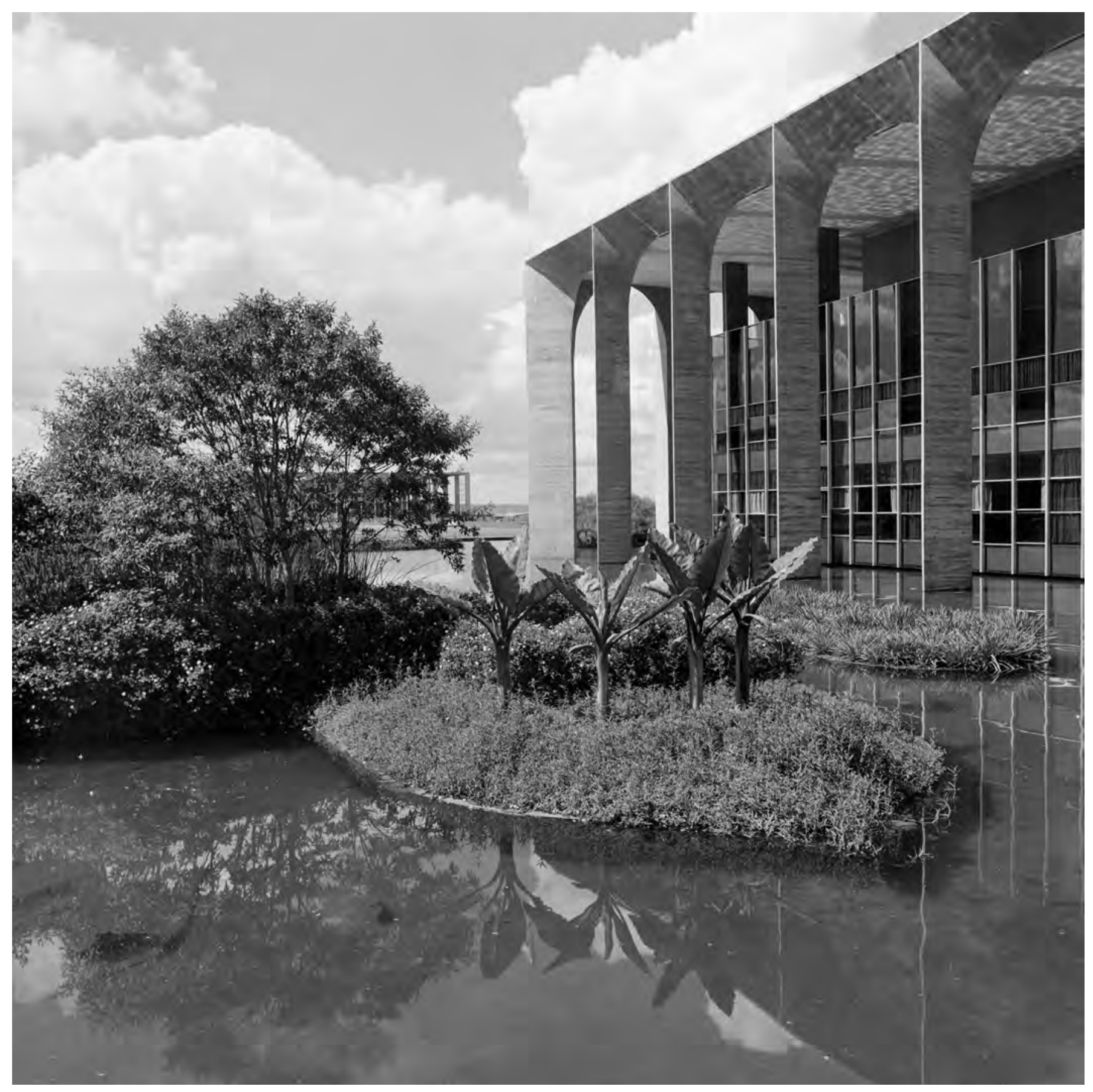

Figura 36: Palácio Itamaraty, Marcel Gautherot, 1968. Fonte: Instituto Moreira Salles. 


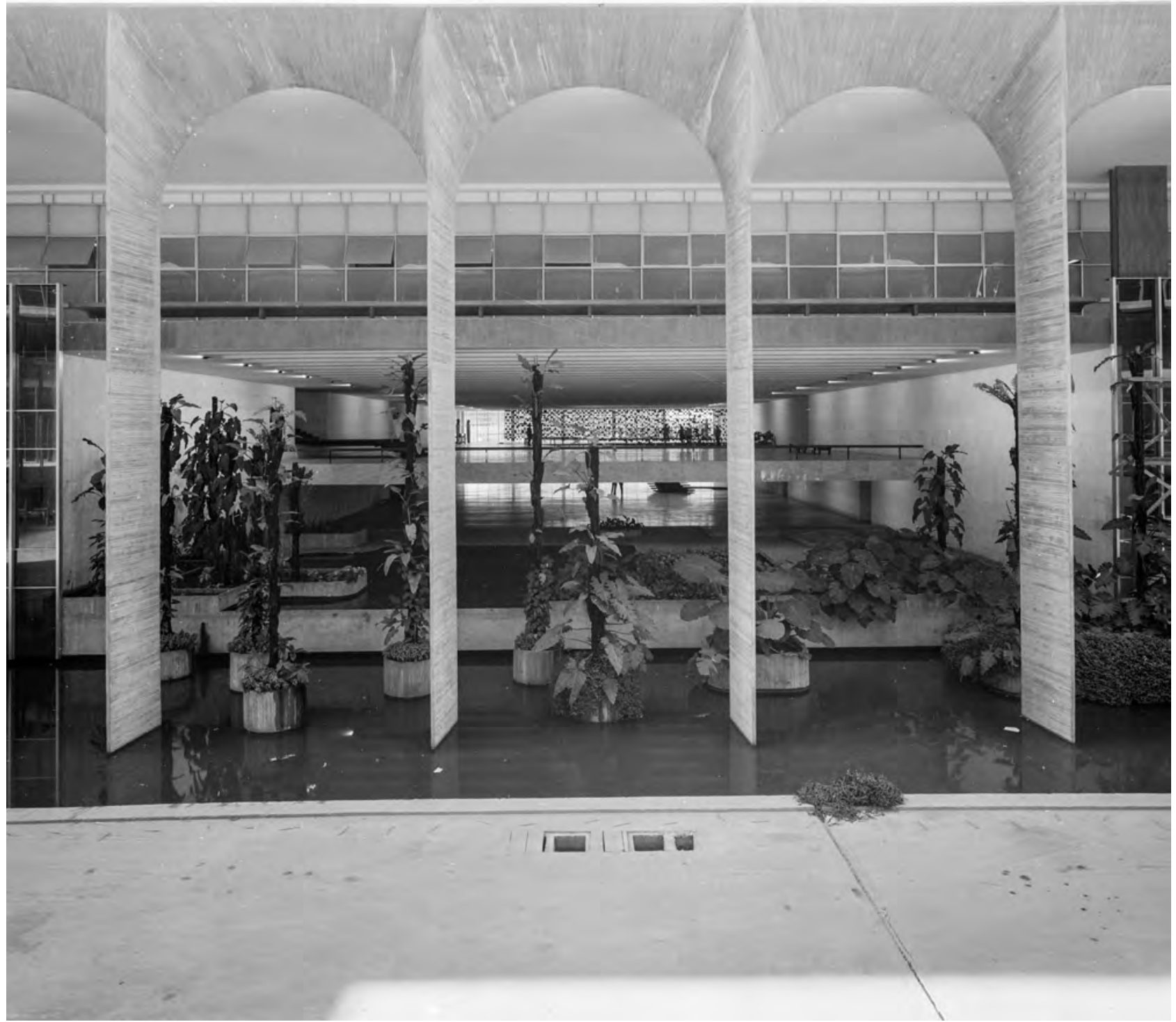

Figura 37: Palácio Itamaraty, Marcel Gautherot, 1968. Fonte: Instituto Moreira Salles.

O encontro entre o jardim interno do térreo e o jardim do espelho d'água resulta na integração harmoniosa entre o ambiente interno do palácio e o externo pelo projeto de paisagismo. 
4. OS ESPAÇOS PALACIANOS / 95

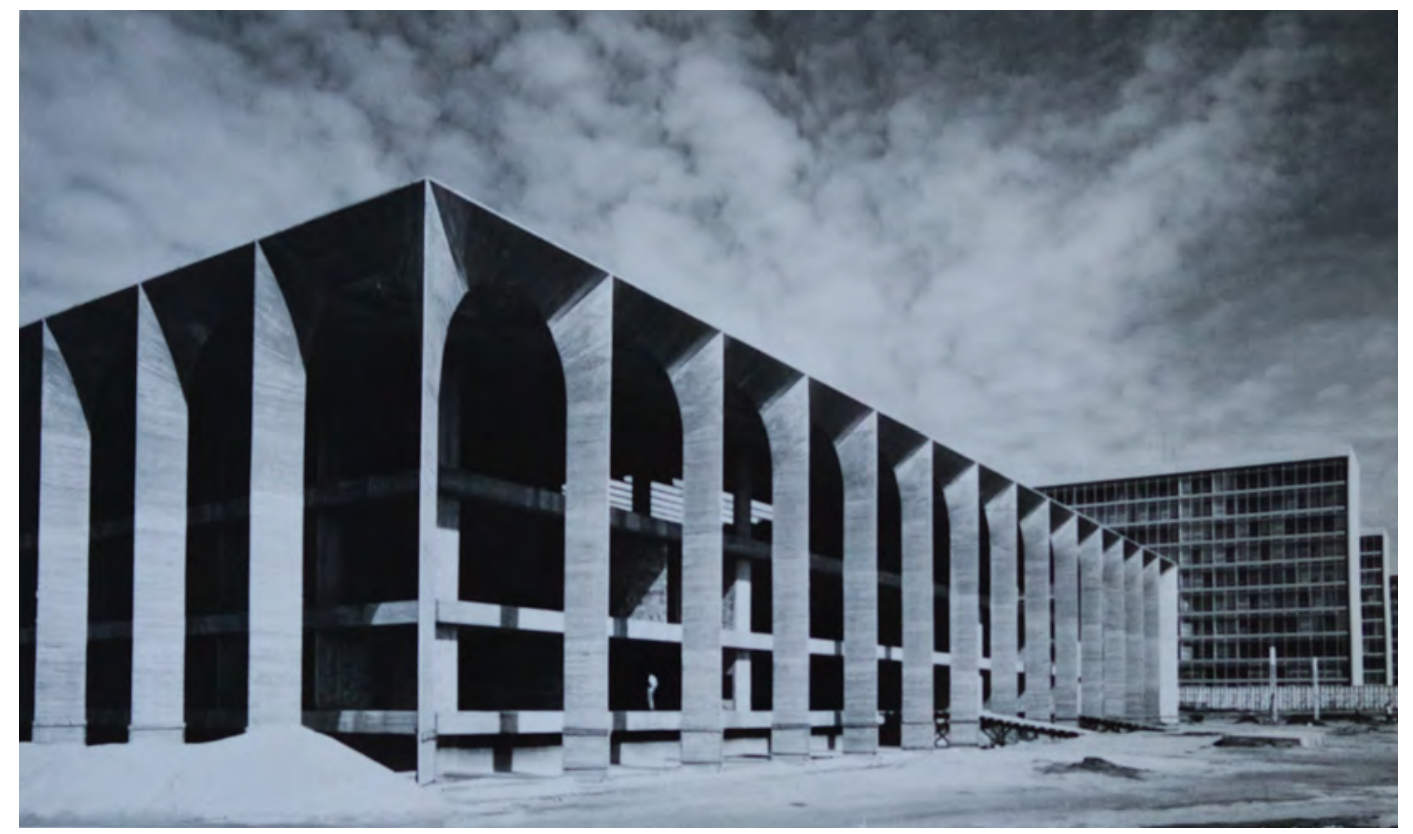

Figura 38: Palácio Itamaraty, Milton Ramos, datação não identificada. Fonte: Acervo Arquiteto MR. 


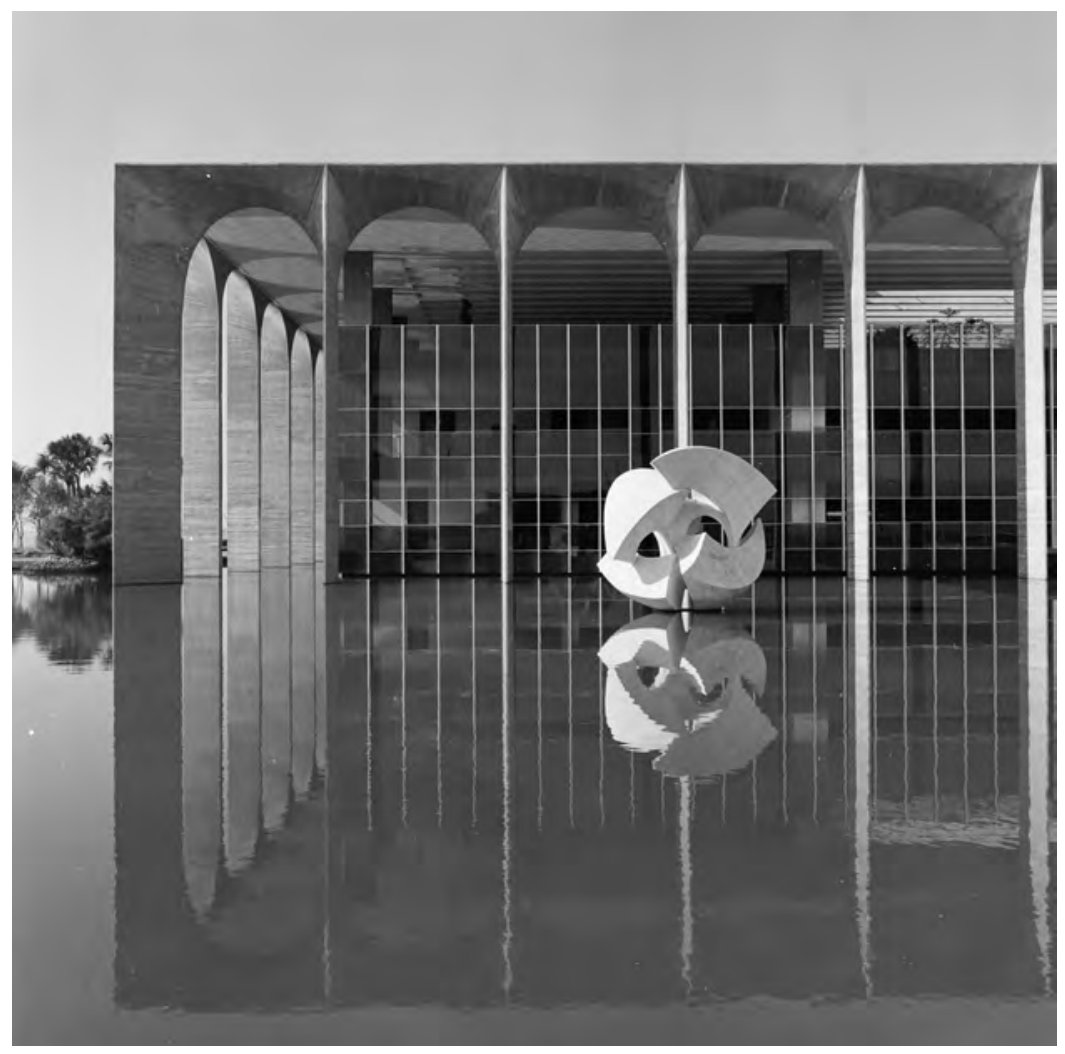

Figura 39: "Meteoro", escultura de Bruno Giorgi, Marcel Gautherot, c.a. 1968. Fonte: Instituto Moreira Salles.

Em 23 de dezembro de 1966, o jornal Correio Braziliense noticiava que “'Meteoro' chega da Itália para ornamentar futura sede do Itamarati em Brasília”. A escultura de Bruno Giorgi, feita em mármore Carrara, flutua no espelho d'água do palácio e foi pensada há, pelo menos, um ano antes de chegar em Brasília. Sobre a escultura frequentemente vista nas fotografias do período de Marcel Gautherot, a mesma nota do jornal diz que "o título nada tem a ver com o Ministério das Relações Exteriores, o prof. Bruno Giorgi disse que a obra servirá apenas como elemento decorativo para complementar o ambiente novo que surgirá com o Palácio dos Arcos" ${ }^{38}$.

A escultura de mármore branco e com poucos veios levou 3 dias para ser montada em Brasília e 800 dias de trabalho na Itália, onde foi talhada por artesãos do estúdio Nicole. A escultura é composta por 3 partes que foram unidas em Brasília. É uma esfera explodida, onde os arcos se encontram e parecem dançar enquanto flutuam. A obra dá a sensação de união entre as partes a partir de suas curvas que dialogam com os arcos do palácio e os semicírculos do Congresso Nacional. 


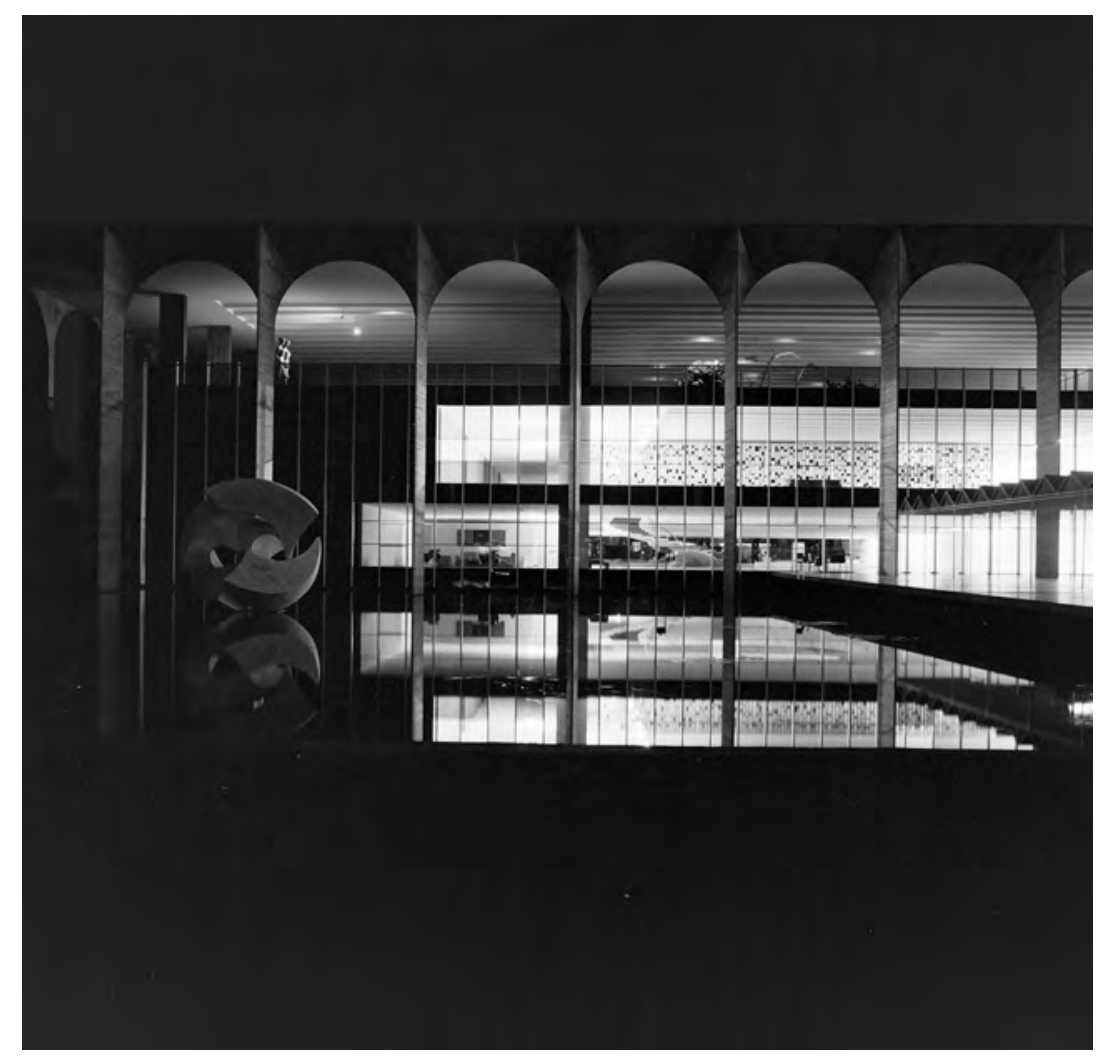

Figura 40: Palácio Itamaraty à noite, Marcel Gautherot, c.a. 1972.

Fonte: Instituto Moreira Salles.

O edifício representativo é formado por uma caixa de vidro de planta quadrada que está recolhida das colunatas nas quatro fachadas iguais. $\mathrm{O}$ vidro de cor fumê - responsável pelo jogo de esconder e mostrar - envolve a caixa. Na parte superior, o vidro não chega até a cobertura do edifício. Tal solução é responsável por soltar a caixa de vidro, o que confere a delicadeza visual do palácio. O plano de vidro também reflete o exterior durante um dia de sol. À noite, possibilita que o interior seja visto, devido à iluminação interna, projetada por Lívio Levi. Ao refletir no espelho d'água, as imagens do palácio e do Meteoro duplicam, criando uma simetria vertical.

Assim, em um primeiro olhar, o palácio parece clássico por sua simetria. Mas, logo depois, o jogo de luz que incide nos frisos oriundos das fôrmas de madeiras tensiona o olhar. Não há estabilidade. O Palácio parece se mover sutilmente - movimento reforçado pelo espelho d'água. Essa experiência visual é resultado dos estudos de acabamento feitos por Milton Ramos, com as fôrmas das ripas de madeira utilizadas no concreto. 
Por fim, um item não solucionado. Desde o início do projeto, há croquis de toldos na rampa de acesso para o palácio. No entanto, o uso de tal item resultaria na poluição visual do edifício. Mesmo assim, um toldo foi colocado. Em seguida, o senador Vasconcelos Torres solicita informações sobre a construção do toldo pelo Requerimento $n^{0} 431$, de 1967 , em que questiona: "Como escapou, à argúcia do responsável, a incrível semelhança do toldo com uma série de esquifes mortuários, alinhados como num necrotério, dando uma nota lúgubre à beleza do palácio?”. A justificativa dada pelo então Ministro Magalhães Pinto era a posse do Presidente Arthur da Costa e Silva, em que o cerimonial da Presidência da República e do Ministério das Relações Exteriores julgaram necessário o toldo como proteção a possíveis chuvas e que "o aspecto a que se refere o requerimento foi, talvez, notado ainda na estrutura metálica. Desaparece uma vez revestida pelo toldo propriamente dito." Em 1985, Niemeyer tenta solucionar com uma cobertura circular, que dialoga com as colunatas, conforme vemos nos croquis (Figura 41). O toldo nunca foi construído. 
4. OS ESPAÇOS PALACIANOS / 99

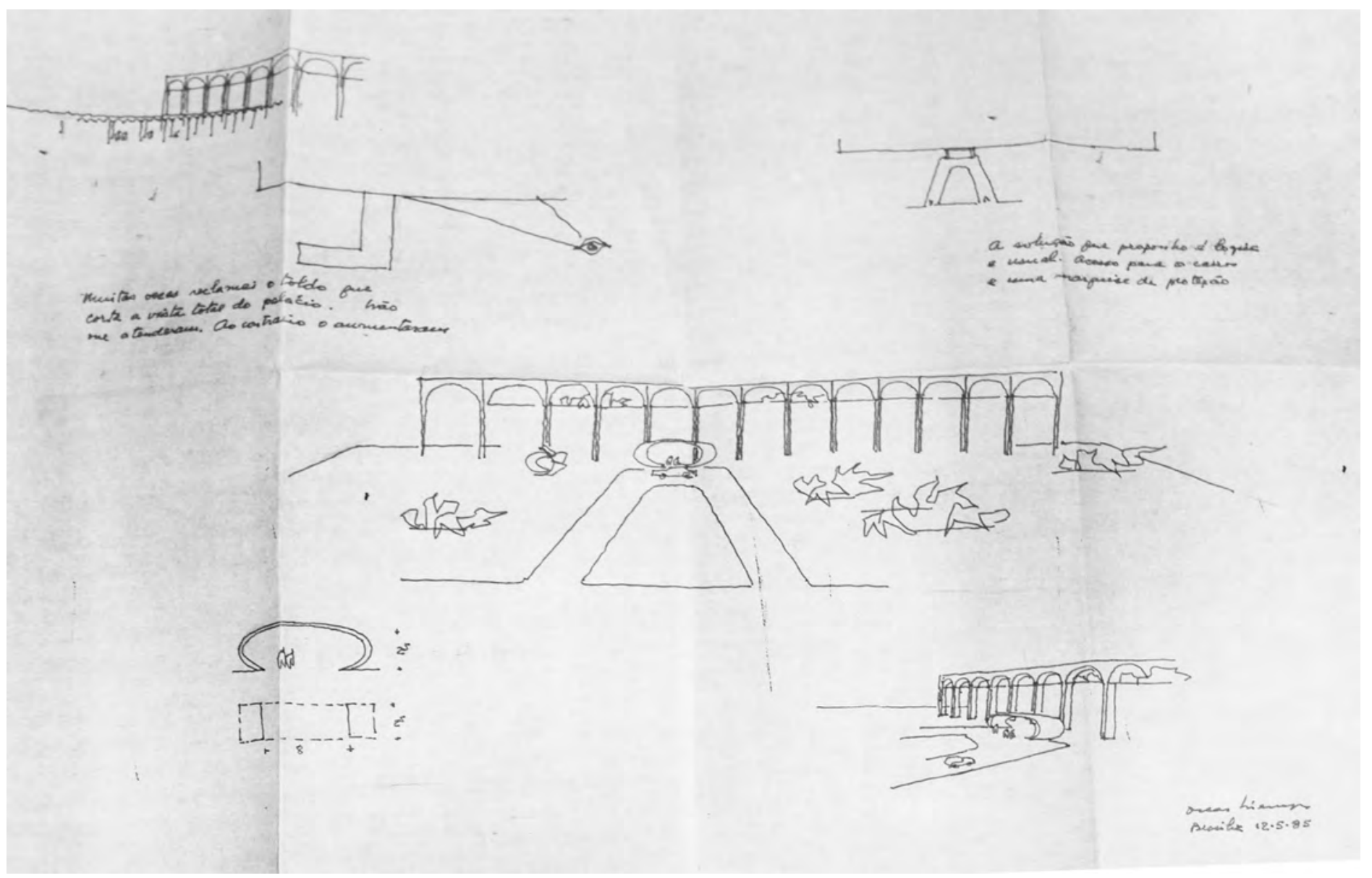

Figura 41: Croquis toldo, Oscar Niemeyer, 1985. Fonte: SARQ. 


\subsection{TÉRREO}

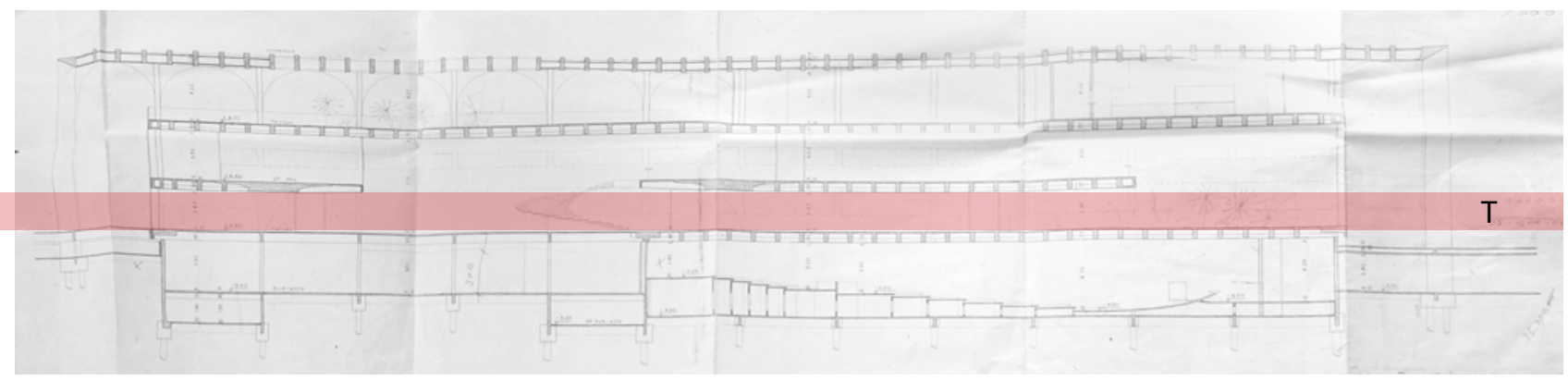

CORTE TRANSVERSAL: INDICAÇÃO ESQUEMÁTICA DO PAVIMENTO 


\section{"O andar térreo com três entradas, sendo uma para o público, outra para o Ministro de Estado e a última para congressos especiais. Terá ainda mais a Sala de Imprensa, portaria e salas de estar" 39}


Consta no memorial descritivo da Companhia Construtora Pederneiras, responsável pela execução das obras, um programa para o edifício de representação de meados de 1964. No térreo, já não está mais o auditório - programa localizado no subsolo, mas havia: hall de entrada, vestíbulo de acesso ao $1^{\circ}$ andar, biblioteca, salão de leitura, mapoteca, salão de consulta, hall privativo do Ministro de Estado, vestíbulo privativo do Ministro de Estado e dependências da portaria (Figura 42). Desses programas, apenas as dependências da portaria mantiveram-se no projeto executado. O espaço destinado ao hall de entrada foi ampliado, o hall e o vestíbulo privativos do Ministro de Estado foram transformados em apartamento. A biblioteca, salão de leitura, mapoteca e salão de consulta foram realocados para os Anexos.

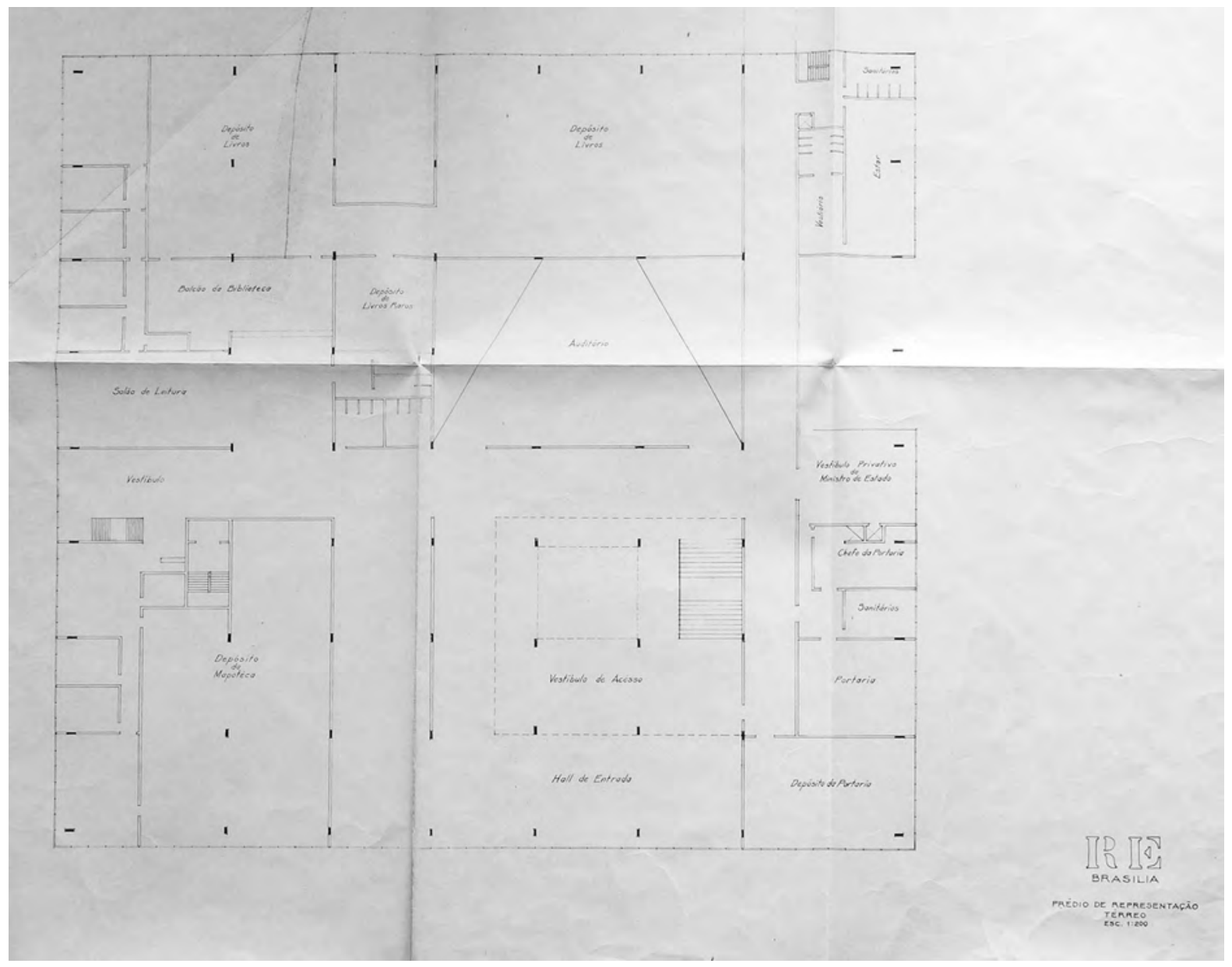

Figura 42: Prédio de Representação - Térreo, datação não identificada. Fonte: SARQ. 
Em outro documento, nomeado como "Prédio de Representação (Distribuição sugerida)" ${ }^{40}$, consta que haveria no térreo: escadaria de honra, jardim de inverno, sala de imprensa, serviço de imprensa do Ministro, conferências de imprensa, oficiais de gabinete, sanitários, depósitos, portaria-chapelaria, elevadores, sanitários, ligação com a secretária de administração, entrada do Ministro de Estado, elevador privativo, entrada do auditório, divisão de difusão cultural e divisão de cooperação intelectual. Este é o programa mais próximo do que foi executado. O térreo é o lugar destinado às recepções, com a escadaria de honra e o jardim de inverno. As áreas destinadas à leitura transformaram-se na área da imprensa. A divisão de difusão cultural e divisão de cooperação intelectual foram para o anexo. Este pavimento, como já descrito no programa anterior, também conta com o espaço privado para o Ministro.

Pelos programas e projetos iniciais, o térreo era um espaço sem expressividadeplástica. Opavimentode acesso aopalácio estaria relacionado, sobretudo, ao conhecimento e a difusão deste - com biblioteca e auditório mas pouco ao cerimonial diplomático. Aliás, o cerimonial ocorreria ao lado do pátio central. Nas palavras de Wladimir Murtinho: "A forma atual foi muito discutida. Eu tinha sugerido que se fizesse um grande quadrado com um pátio no meio, essa era minha ideia, porque funcionava muito bem para fazer grandes recepções ao ar livre" (MURTINHO, 1990, p. 18) (vide Figura 43). Este ambiente, provavelmente pensado a partir do espelho d'água do palácio no Rio de Janeiro, foi, posteriormente, destinado para ocupar o Terceiro Pavimento, a varanda.

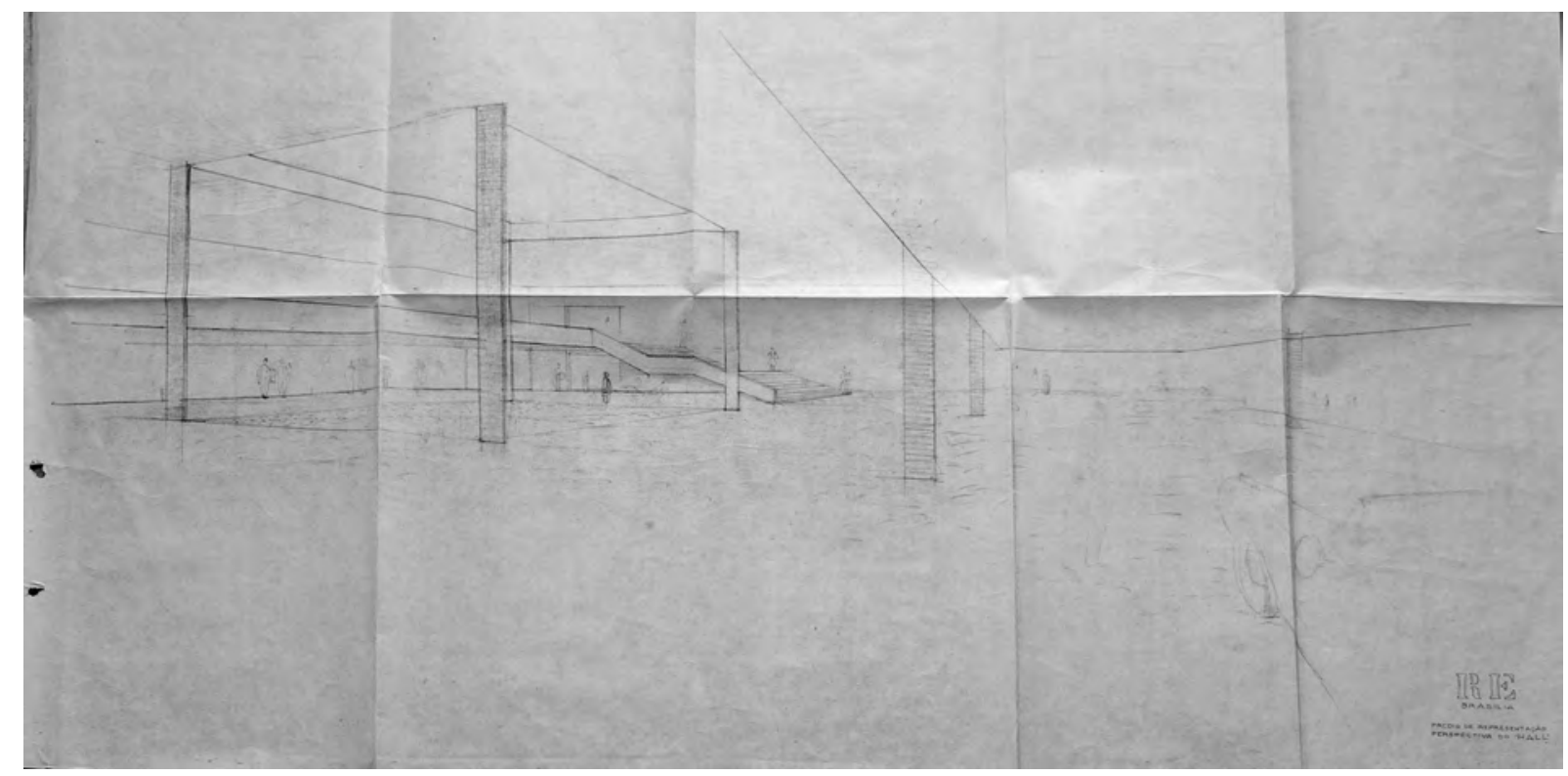

Figura 43: Prédio de Representação - Perspectiva do Hall, datação não identificada. Fonte: SARQ.

40 O documento faz parte do acervo do Setor de Arquitetura do Ministério das Relações Exteriores (SARQ). 
Além do pátio central, havia uma escada retangular (Figura 43). O desenho da escada helicoidal aparece só em um projeto de fevereiro de 1964. Para chegar a esta solução, os arquitetos Oscar Niemeyer e Milton Ramos trocaram croquis (Figura 44). A escada helicoidal foi elaborada por Milton Ramos e foi calculada por Joaquim Cardozo.

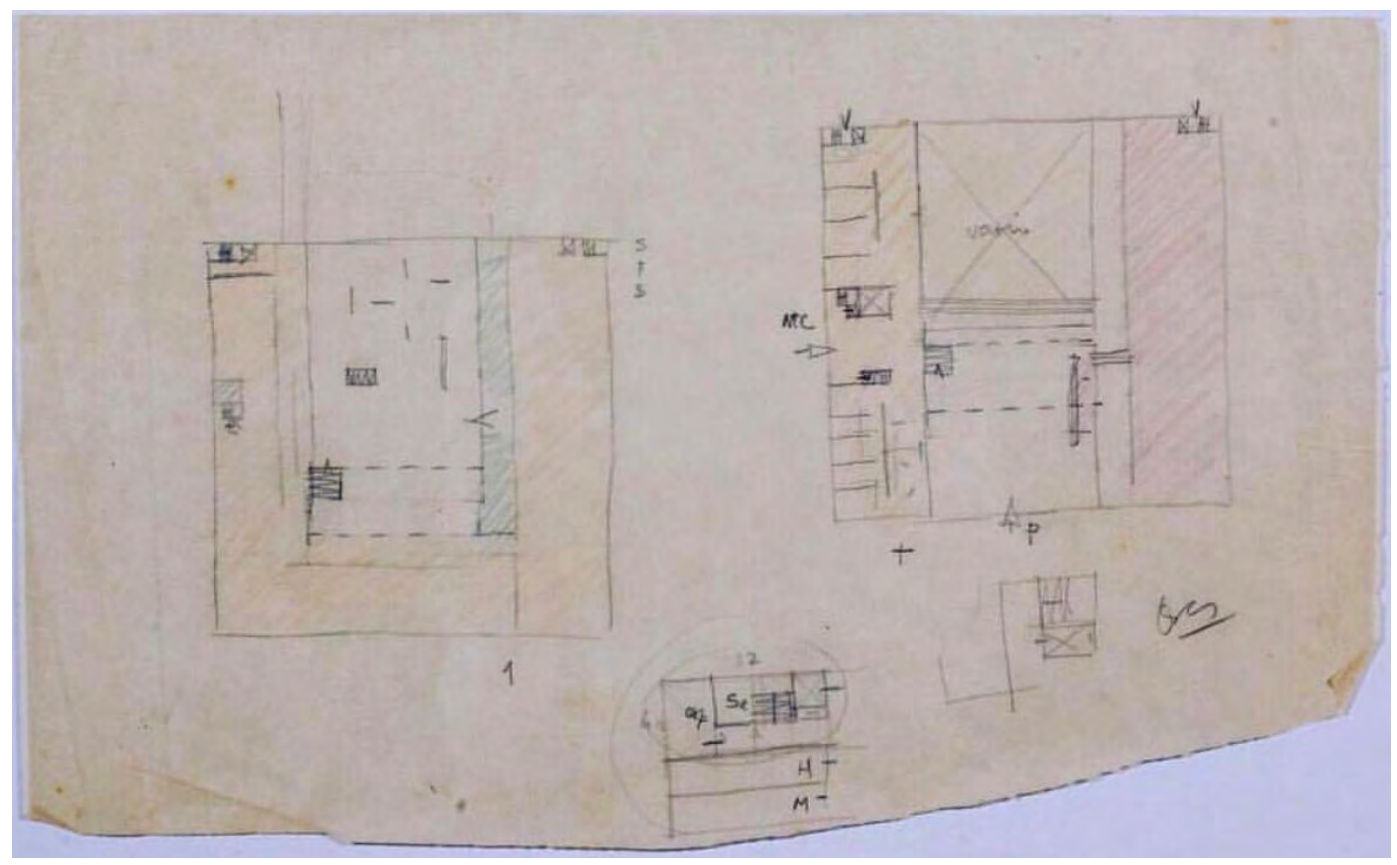

Figura 44: Croquis de Oscar Niemeyer entregues à Milton Ramos, datação não identificada. Fonte: Acervo arquiteto MR.

A escada é o gerador do projeto do térreo (Figura 45). Milton Ramos utilizou ripas de madeira na fôrma, que acompanhavam o desenho da hélice, para dar a forma da escada. A partir do desenho da escada, o espaço e as obras de arte do térreo foram desenvolvidos. $\mathrm{O}$ caminhar pelo edifício ocorre por pavimentos e, assim, o uso da escada, sem corrimão, para atingir o próximo andar possibilita um acesso pausado - ao mesmo tempo - é possível observar o interior do palácio, as obras de arte e o exterior. De modo que a escada helicoidal permite que o hall, primeiro ambiente onde ocorre o cerimonial diplomático, possa ser visto de várias perspectivas. 
4. OS ESPAÇOS PALACIANOS / 105

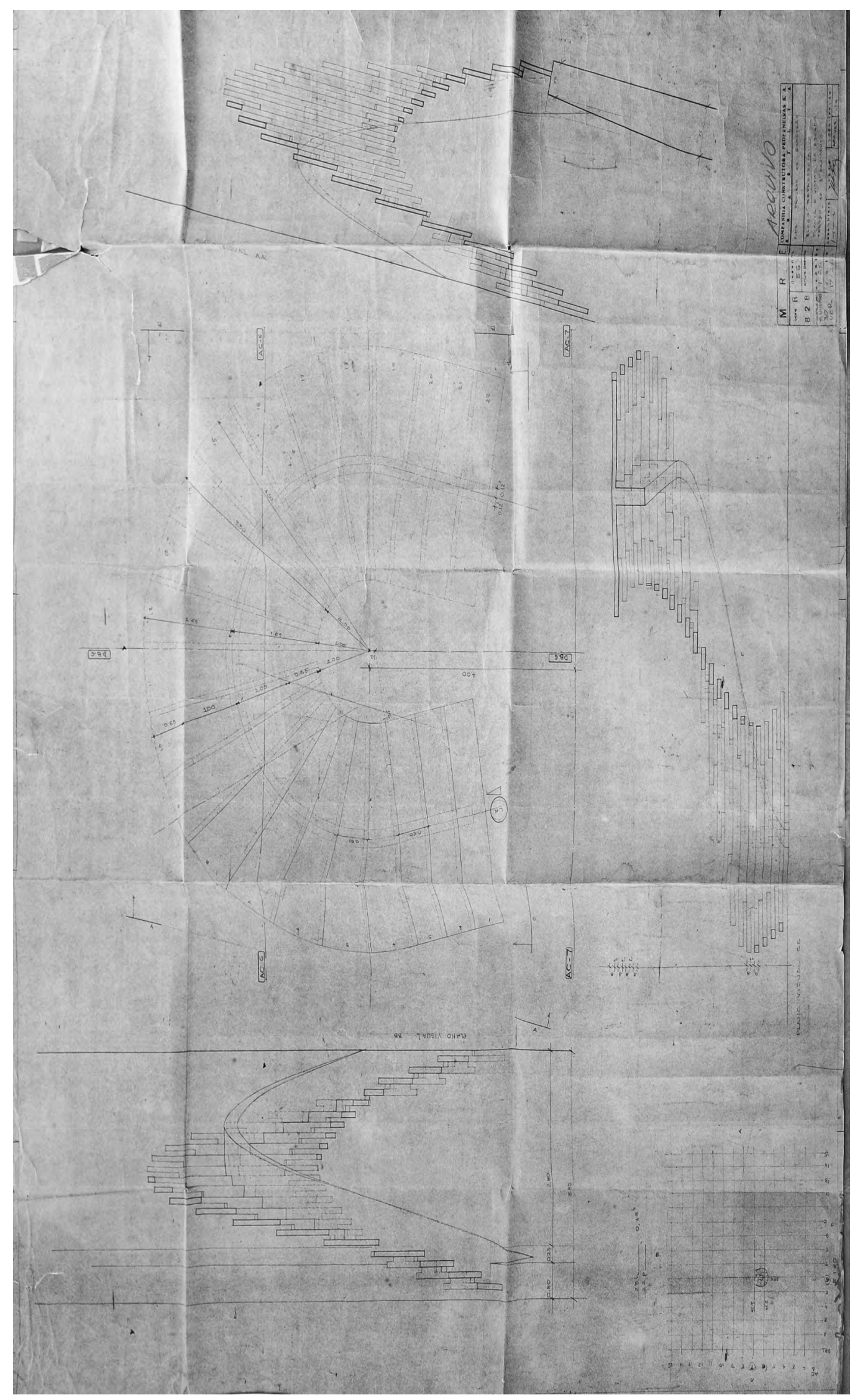

Figura 45: Planta e Vistas da escada térreo ao $1^{\circ}$ pavimento, 1964 . Fonte: SARQ. 


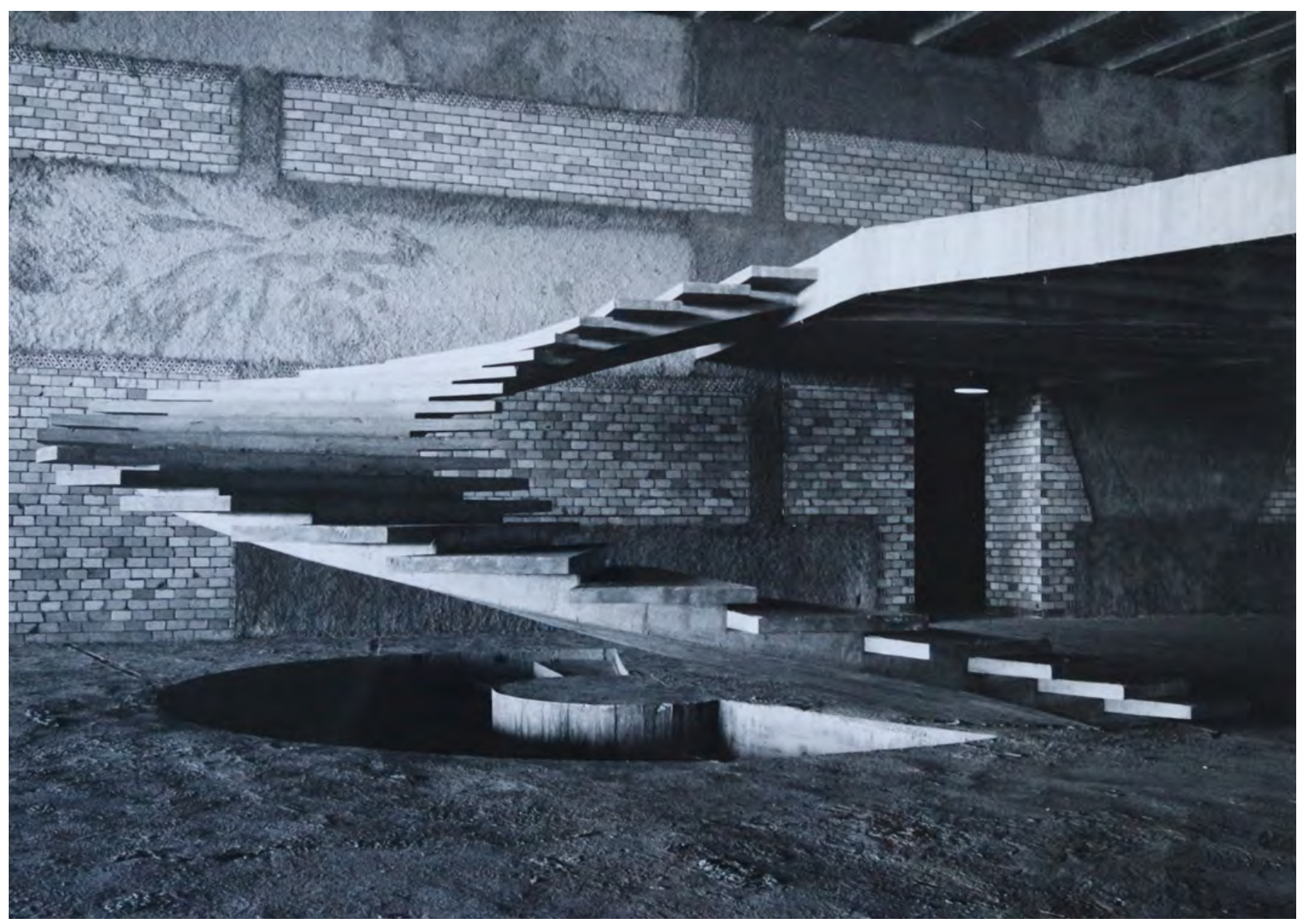

Figura 46: Escada helicoidal, Milton Ramos, datação não identificada. Fonte: Acervo arquiteto MR. 
4. OS ESPAÇOS PALACIANOS / 107

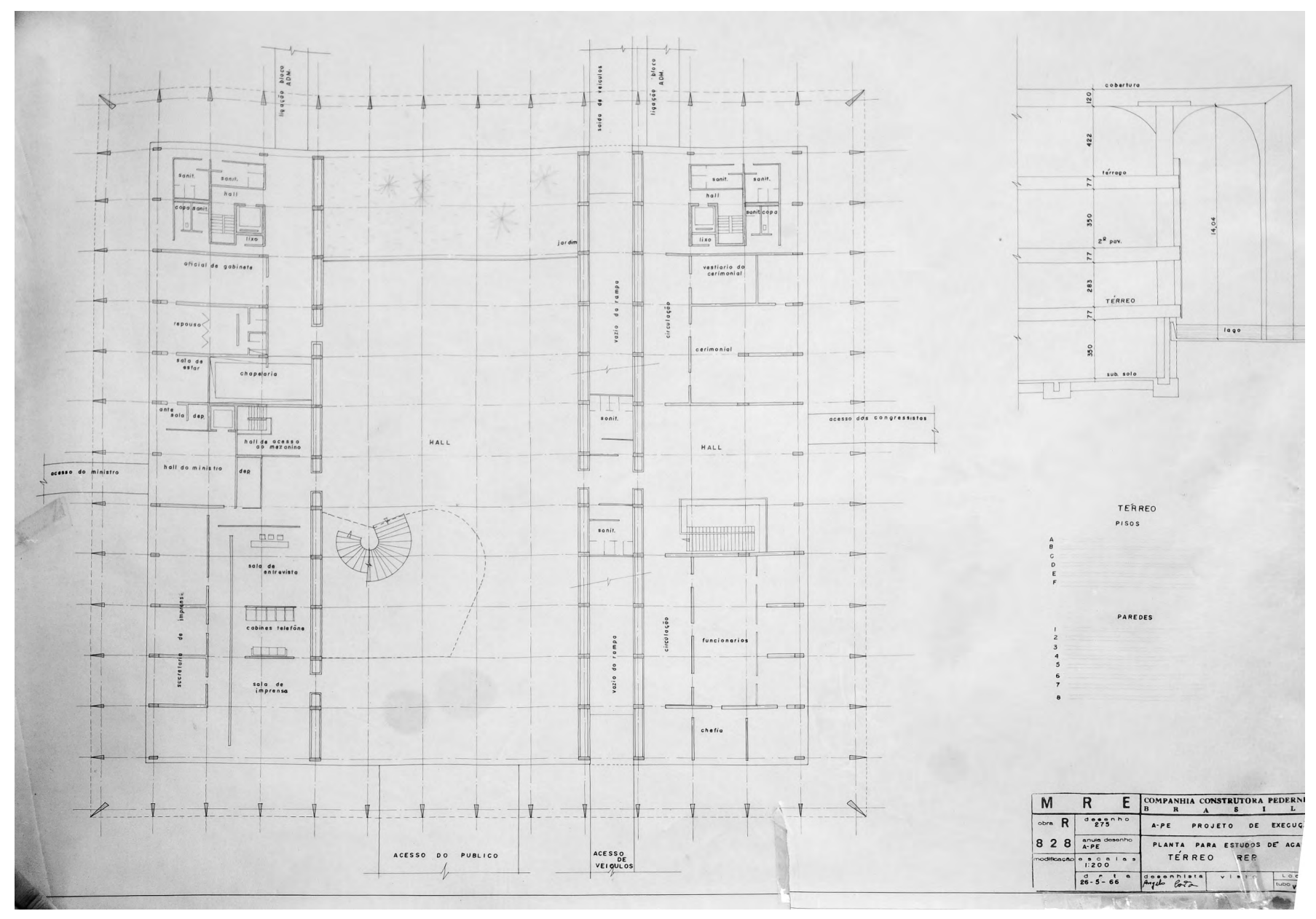

Figura 47: Planta para estudos de acabamento - Térreo, 1966. Fonte: SARQ.

Em 1966, o projeto está definido. O térreo é dividido em três seções longitudinais paralelas: o grande hall, a parte de serviços de apoio, como a sala do cerimonial, o apartamento do ministro e a sala da imprensa. O grande hall é onde começa o cerimonial diplomático. O espaço destinado às recepções ocupa a área central do térreo e é composto pela escada de honra, o jardim, projetado por Burle Marx, e o mural desenhado por Athos Bulcão. 


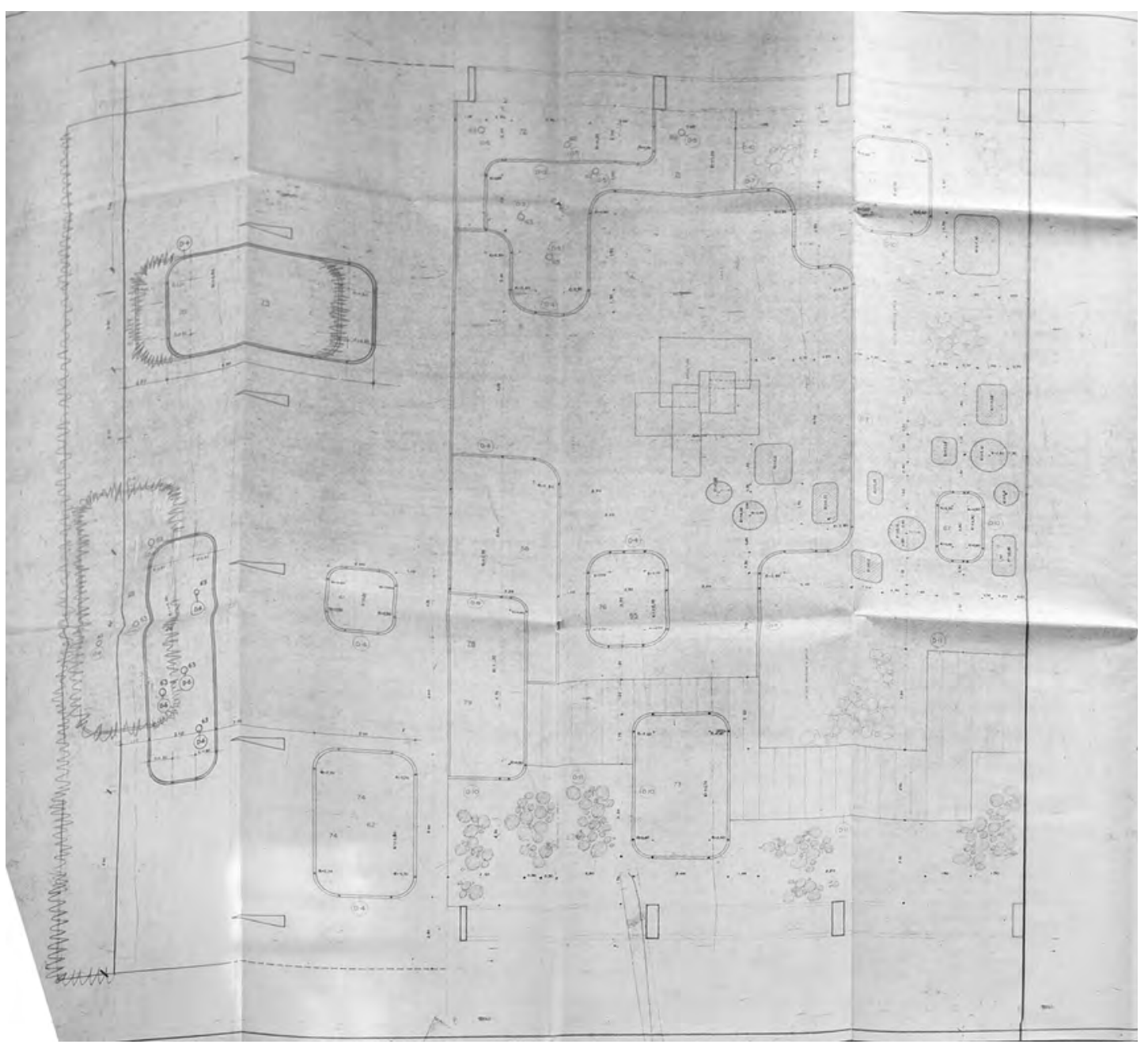

Figura 48: Planta de cotas - jardim do térreo, Roberto Burle Marx, 1966. Fonte: SARQ. 
O paisagismo do jardim interno no térreo está em diálogo e na mesma cota que o jardim ao entorno do palácio. Todos foram elaborados em 1966 e executados em 1967, acompanhando as obras do projeto de arquitetura.

O jardim do térreo é formado por pedras e seixos, tornando possível o caminhar sobre ele. O pensamento é semelhante ao do jardim externo: canteiros únicos em formatos geométricos regulares com as arestas arredondas colocados no espelho d'água. As espécies de plantas escolhidas são mais volumosas do que as do jardim externo. O espelho d'água reflete as colunatas do edifício. A princípio teria uma escultura de água, eliminada no projeto executado (Figura 49 e Figura 50).

O jardim interno está no centro da planta do térreo e é contínuo ao jardim externo pelo espelho d'água. O jardim do térreo está entre dois lugares: na relação com o externo e também com o Segundo Pavimento, a partir dos totens de concreto envolvidos pelos Filodendros Ondulados que atingem a altura do Segundo Pavimento, verticalizando a leitura interna do edifício. De modo que do Segundo Pavimento é possível olhar para o jardim do térreo e também para o exterior do edifício (Figura 53).

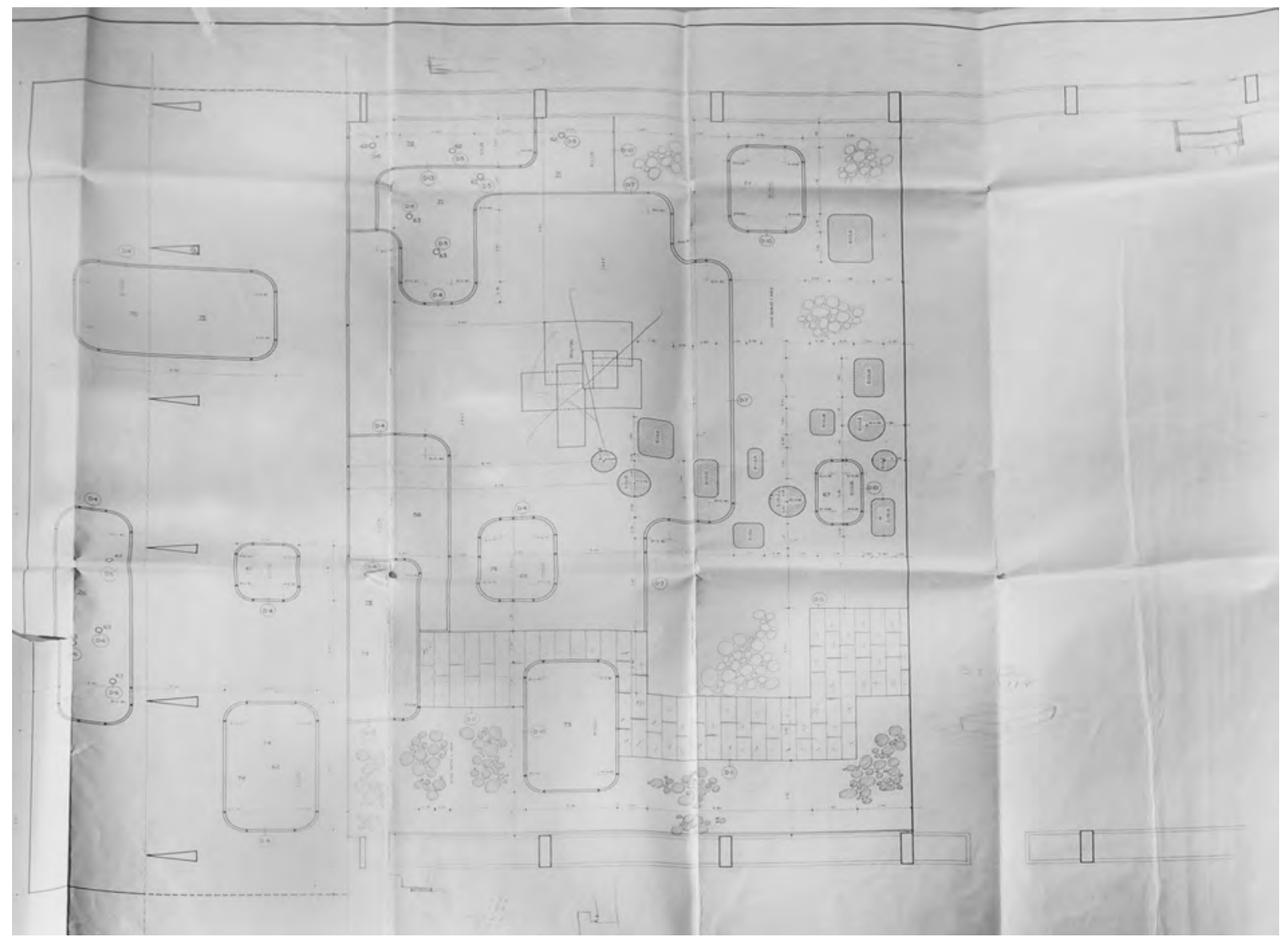

Figura 49: Planta de cotas - Lista de plantas, Roberto Burle Marx, 1966. Fonte: SARQ. 


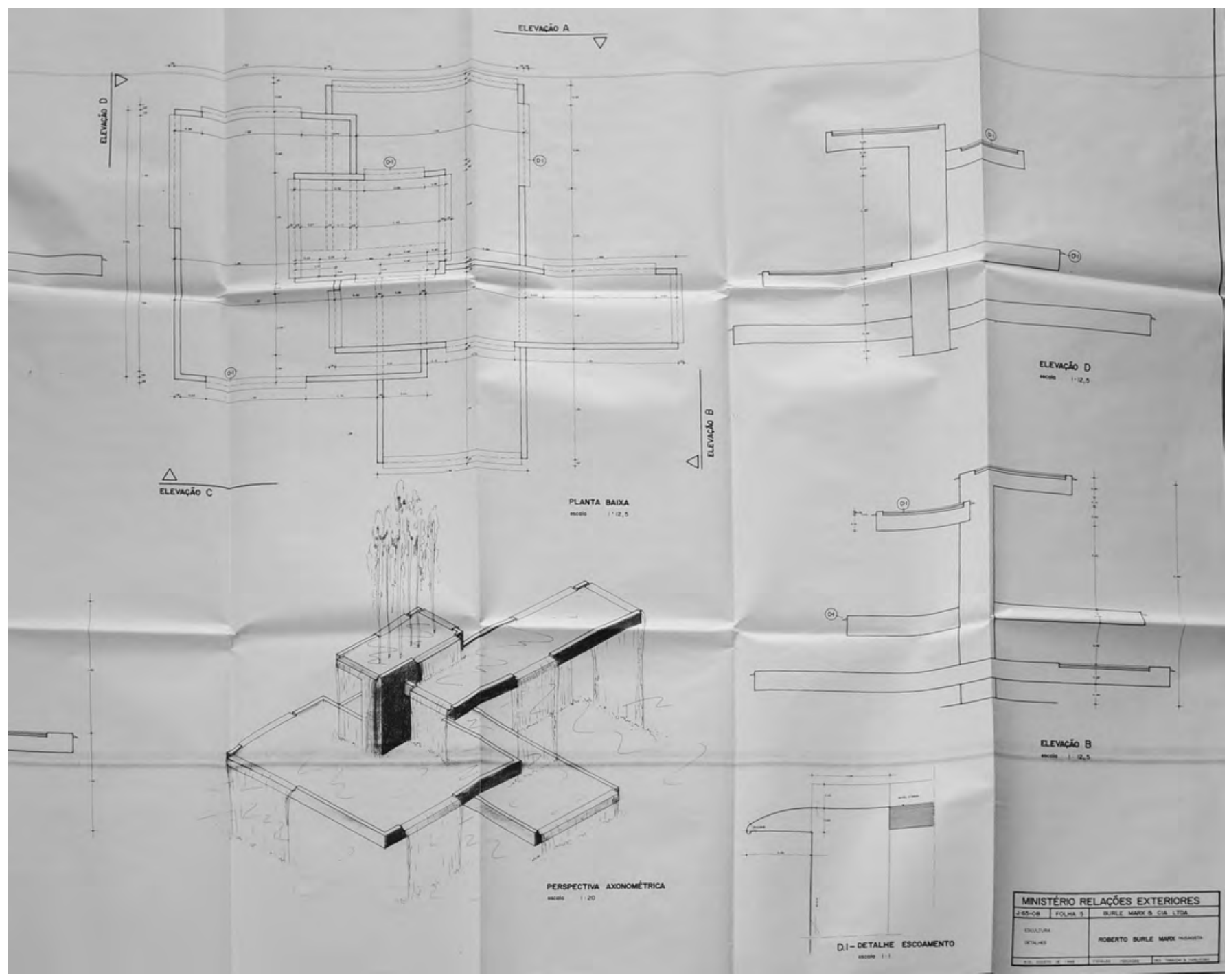

Figura 50: Escultura detalhes, Roberto Burle Marx, 1966. Fonte: SARQ. 
4. OS ESPAÇOS PALACIANOS / 111

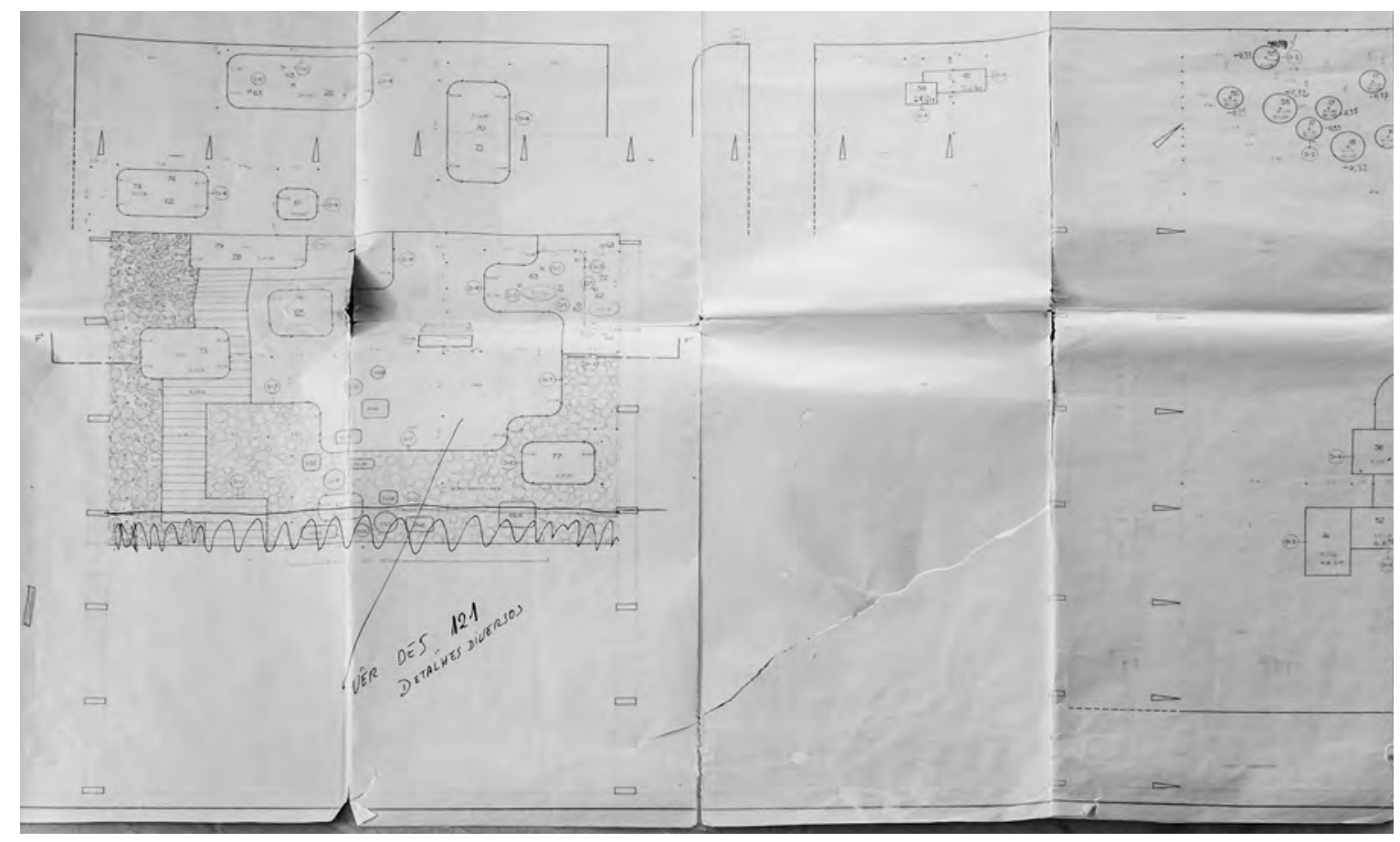

Figura 51: Lista de Plantas, Lista de cotas, Roberto Burle Marx, 1966. Fonte: SARQ.

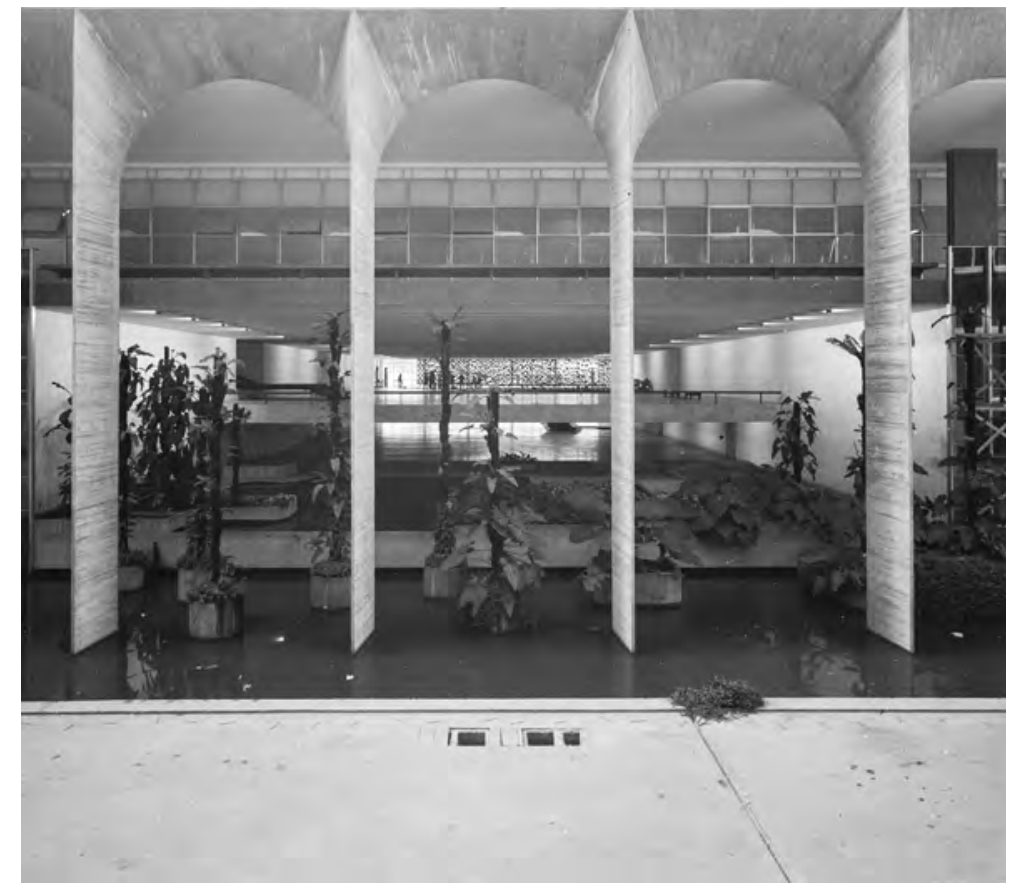

Figura 52: Jardim térreo, Marcel Gautherot, c.a. 1968.

Fonte: Instituto Moreira Salles. 


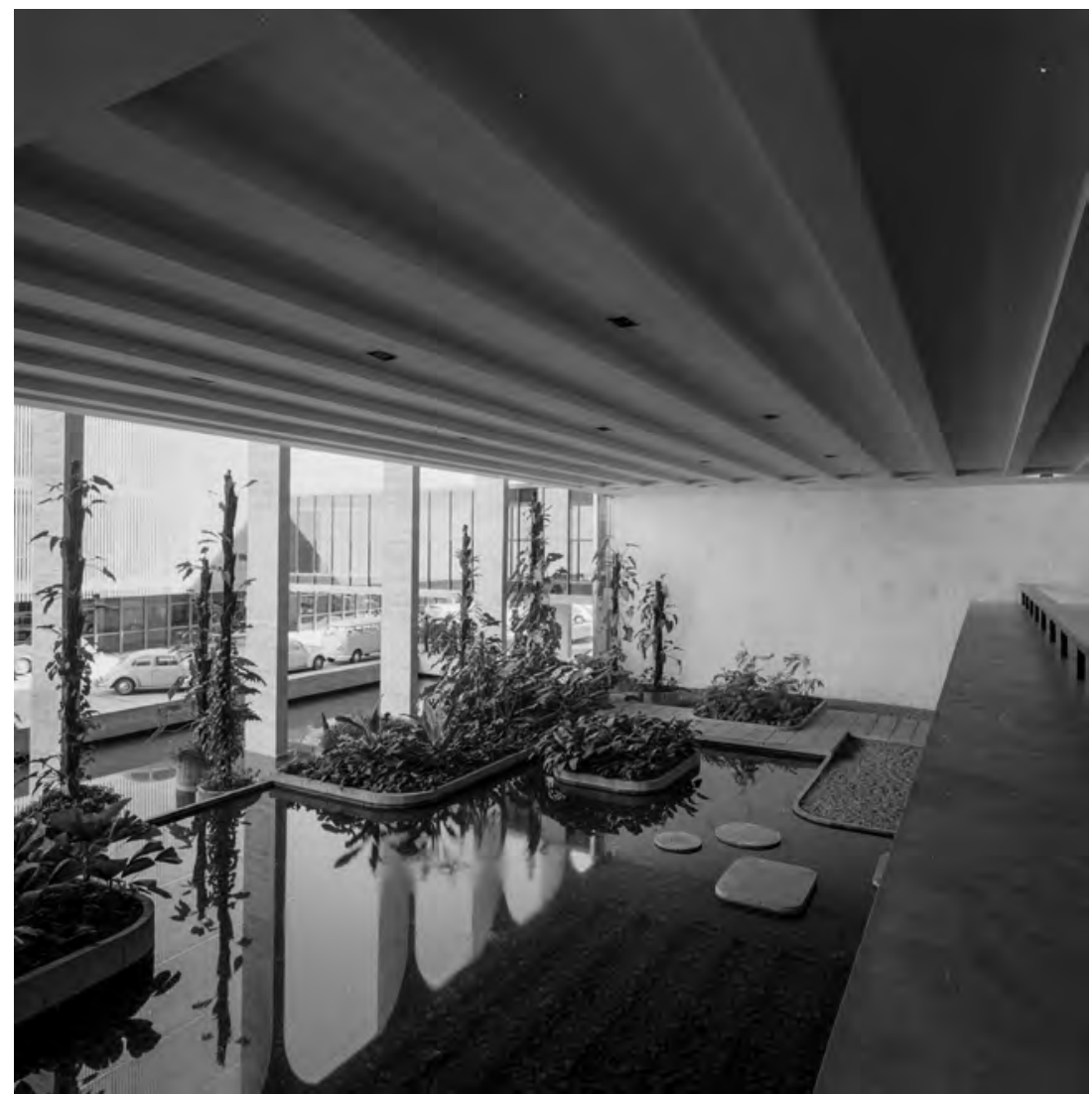

Figura 53: Jardim térreo, Marcel Gautherot, c.a. 1968. Fonte: Instituto Moreira Salles.

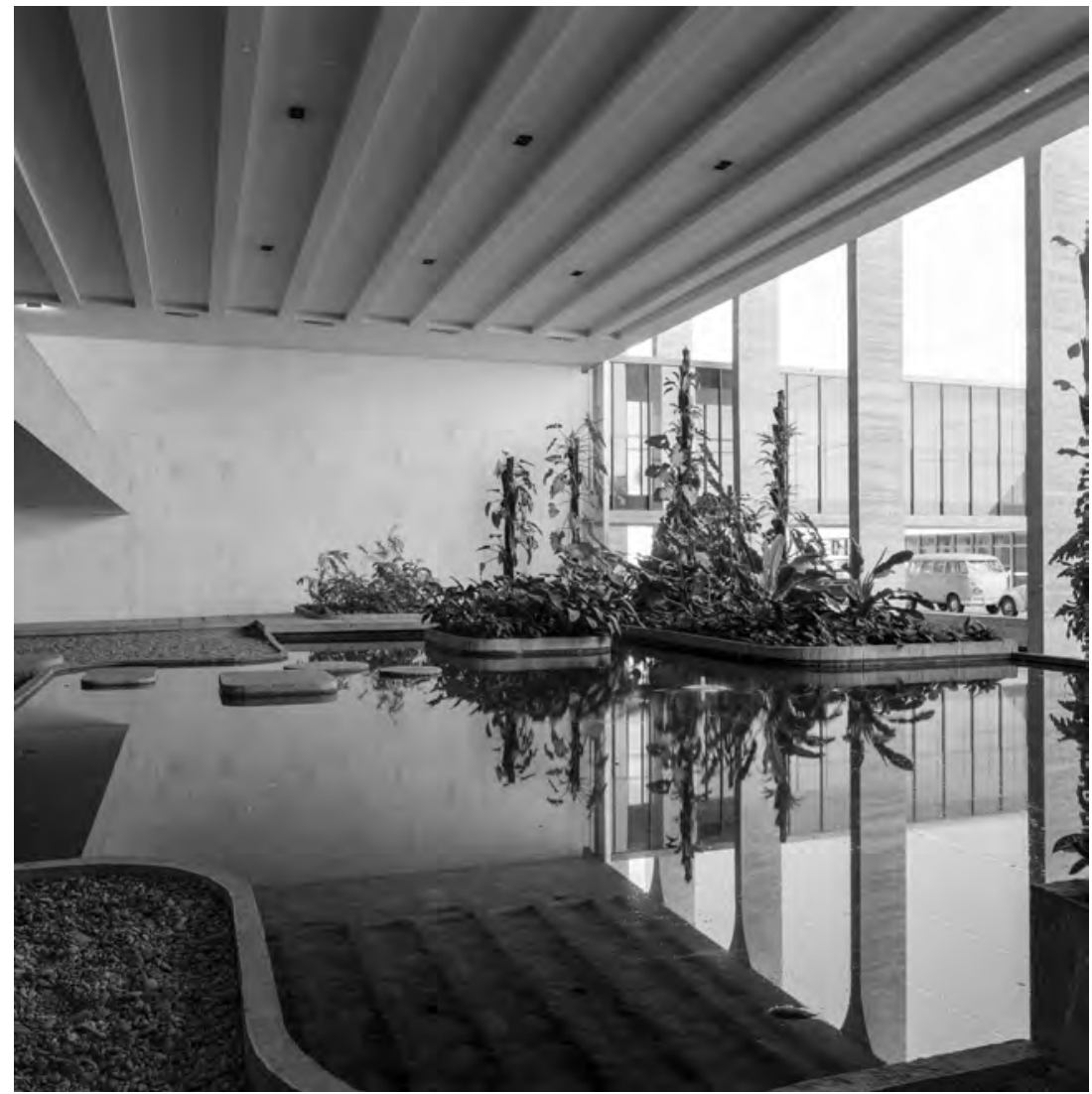

Figura 54: Jardim térreo, Marcel Gautherot, c.a. 1968. Fonte: Instituto Moreira Salles. 
4. OS ESPAÇOS PALACIANOS / 113

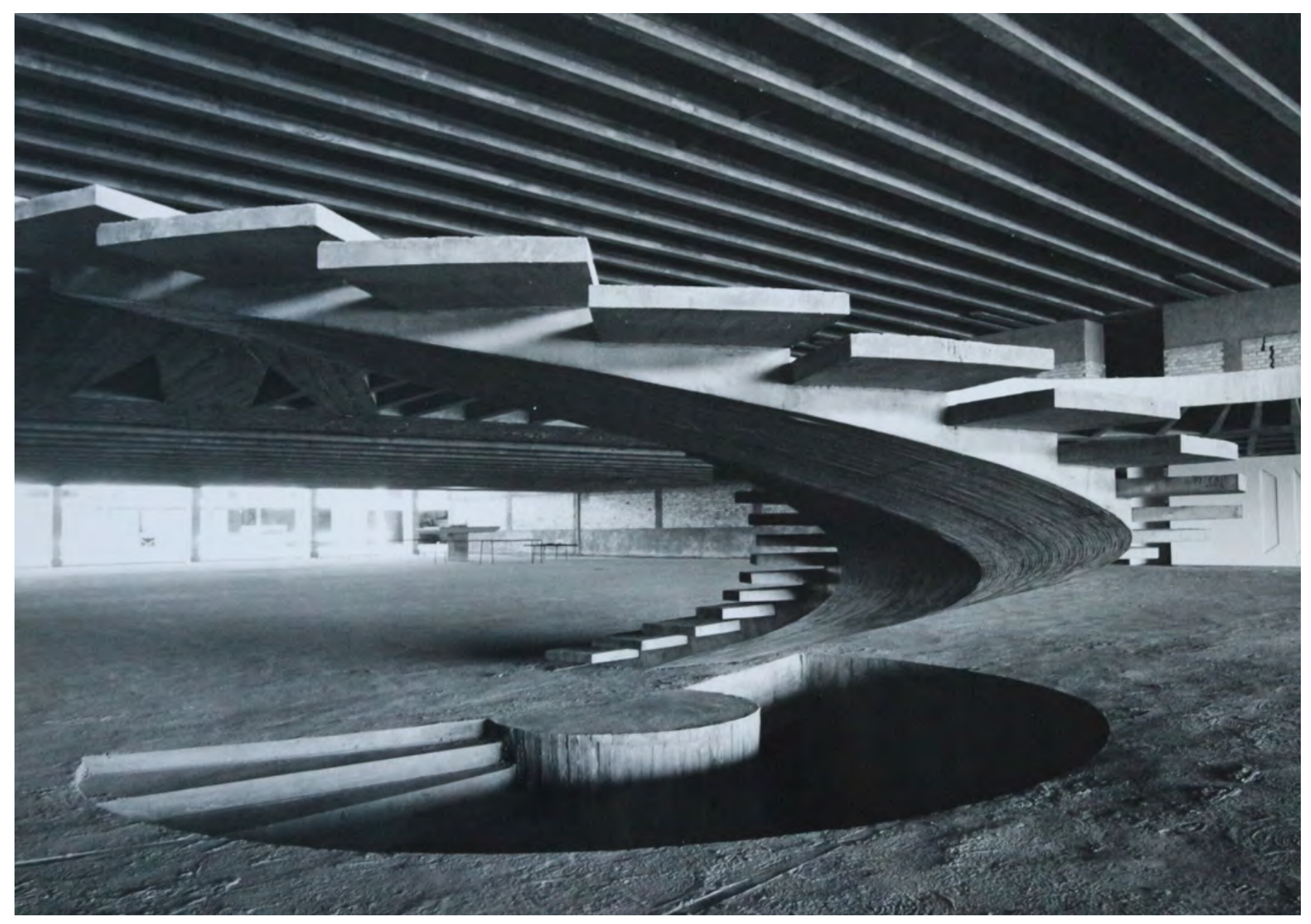

Figura 55: Escada helicoidal, Milton Ramos, datação não identificada. Fonte: Acervo arquiteto MR. 


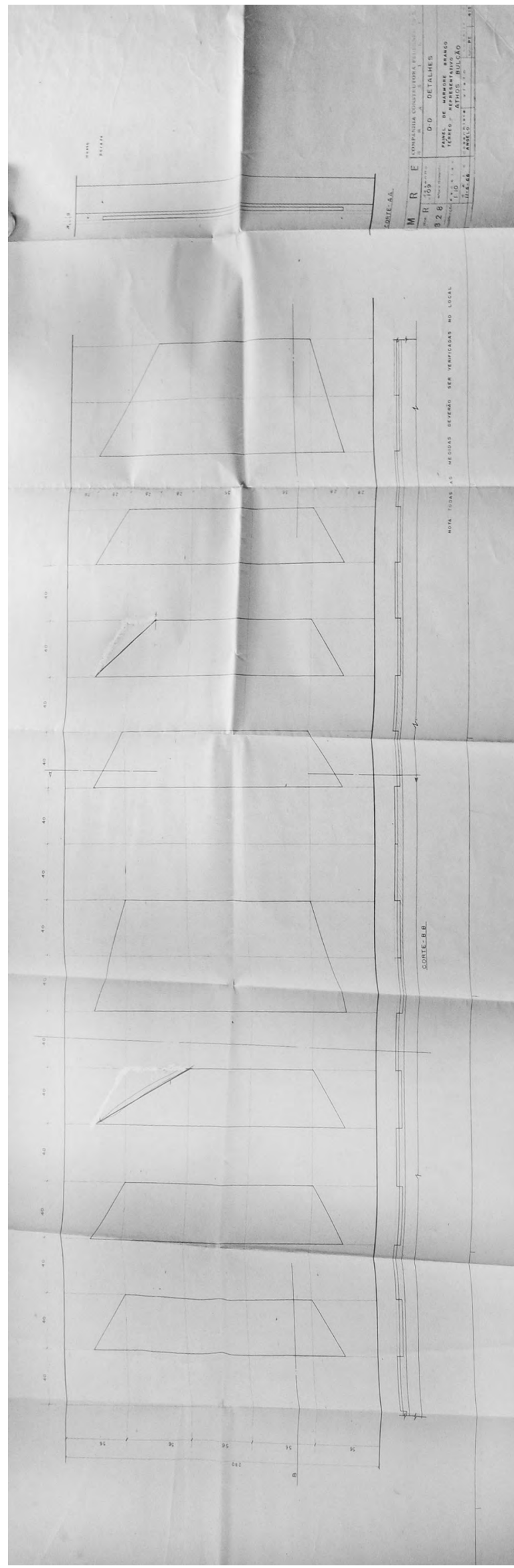

Figura 56: "Relevo em Mármore" - Athos Bulcão, 1966.

Fonte: SARQ. 
Athos Bulcão foi responsável pelo desenho do piso e das paredes. A parede é revestida em mármore Santo Antônio, branco e apicoado. O piso do hall foi desenhado em 1966, feito em granito andorinha cinza. É o mesmo revestimento utilizado nas rampas de acesso para o palácio no lado externo. Assim, exterior e interior são unificados pelo desenho do piso. O painel, nomeado como Relevo em Mármore, foi feito em mármore branco apicoado e executado durante a obra de arquitetura. No Relatório de Despesas de Wladimir Murtinho foi considerado como obra de arte integrada. Este mural é formado por trapézios verticalizados, em baixo relevo, com alturas de 40 $\mathrm{cm}$ e $80 \mathrm{~cm}$, alterando a inclinação dos ângulos dos lados de cada trapézio. $O$ ritmo é dado por uma média de três trapézios de $40 \mathrm{~cm}$ de altura por um de $80 \mathrm{~cm}$. O mural de Athos Bulcão começa na entrada principal do palácio e termina no jardim interno de Burle Marx.

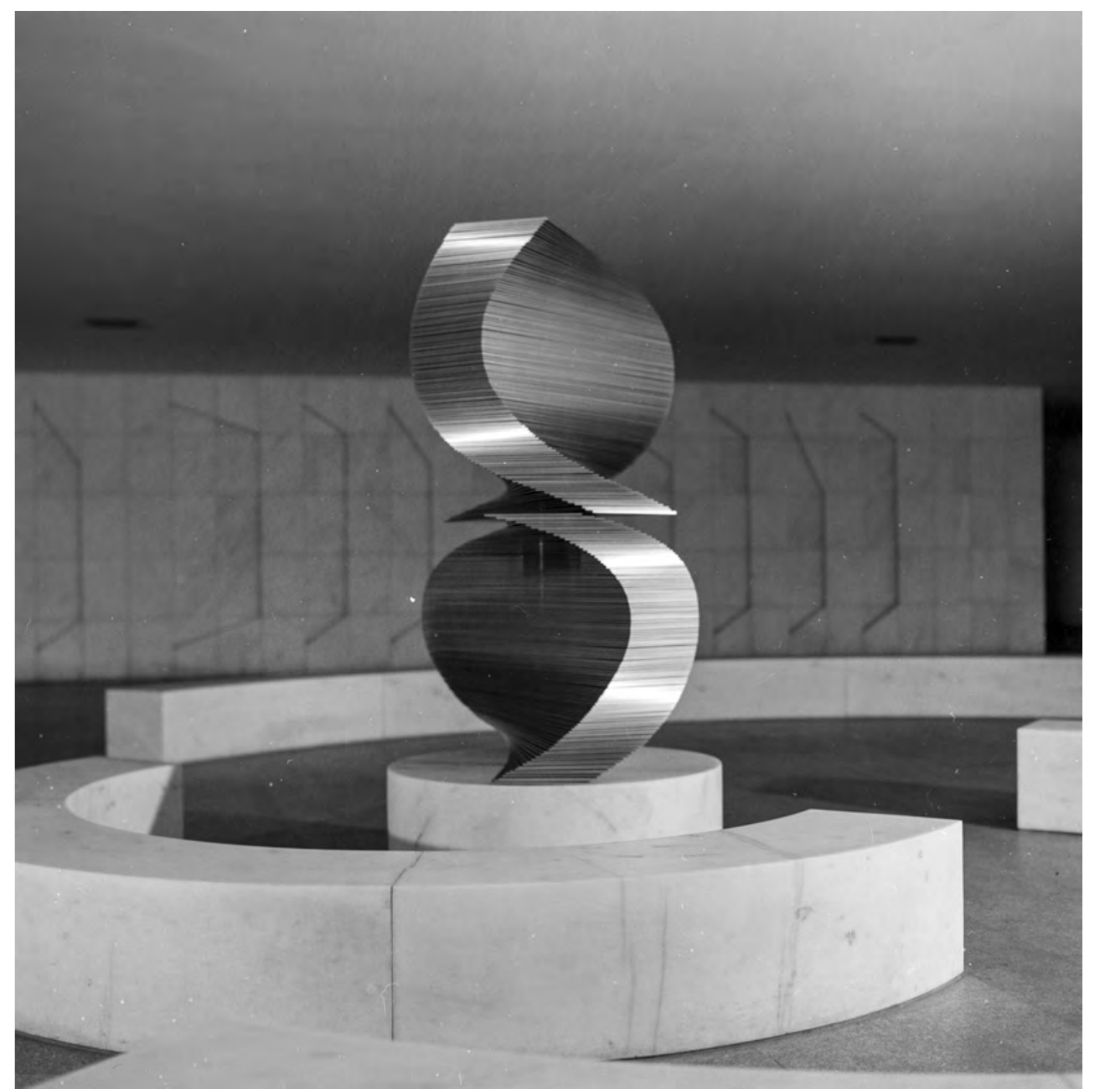

Figura 57: "Polivolume: Ponto de Encontro" - Mary Vieira, Marcel Gautherot, c.a. 1970. Fonte: Instituto Moreira Salles. 
O jardim, a escada helicoidal e o Relevo em Mármore foram pensados ao mesmo tempo que o projeto arquitetônico, entre 1966 e 1967. Também foram executados durante a obra de arquitetura. No entanto, a escultura Polivolume: Ponto de Encontro de Mary Vieira tem seu projeto posteriormente, iniciado em 1968. Não por acaso, não consta no relatório de Wladimir Murtinho, nem nos projetos elaborados para o térreo. A obra é feita em alumínio anodizado e mármore branco das minas de Cachoeiro de Itapemirim e preparado pela Italva e pela Marmifera e foi "encomendada há dois anos passados pelo arquiteto Oscar Niemeyer"41. Há um projeto da escultura desenhado pela Construtora Pederneiras, em 1968. Sua execução terminou em 1970, quase na abertura do palácio, com a presença da artista:

Mary Vieira espera que a montagem esteja concluída na próxima semana e relembrou o episódio de dois anos atrás, quando construiu um modelo em madeira, para mostrar ao Embaixador Murtinho e ao arquiteto Niemeyer. 'Nessa oportunidade é que surgiu o nome, pois, ali tínhamos nos encontrado e a escultura, único ponto no amplo hall vazio, será, naturalmente, um "ponto de encontro", explicou Mary Vieira. ${ }^{42}$

A escultura é formada por uma base cilíndrica em mármore com placas retangulares de alumínio e 3 linhas curvas esculpidas em mármore que aumentam de tamanho, conforme se distanciam da base. Para Mary Vieira, a escultura:

Ponto de encontro: interligação plástico espacial com a arquitetura interior do Palácio e, ao mesmo tempo, forma de estabelecer um novo conceito de sociabilidade da arte, um símbolo de encontro permanente entre o nosso país e as demais nações. ${ }^{43}$

\footnotetext{
41 AULER, Hugo. Atelier. Jornal Correio Braziliense, Brasília, 09 de setembro de 1969. p. 10.

42 Ponto de encontro. Correio Diplomático. Jornal Correio Braziliense, Brasília, 10 de abril de 1970. p. 5.
} 
4. OS ESPAÇOS PALACIANOS / 117

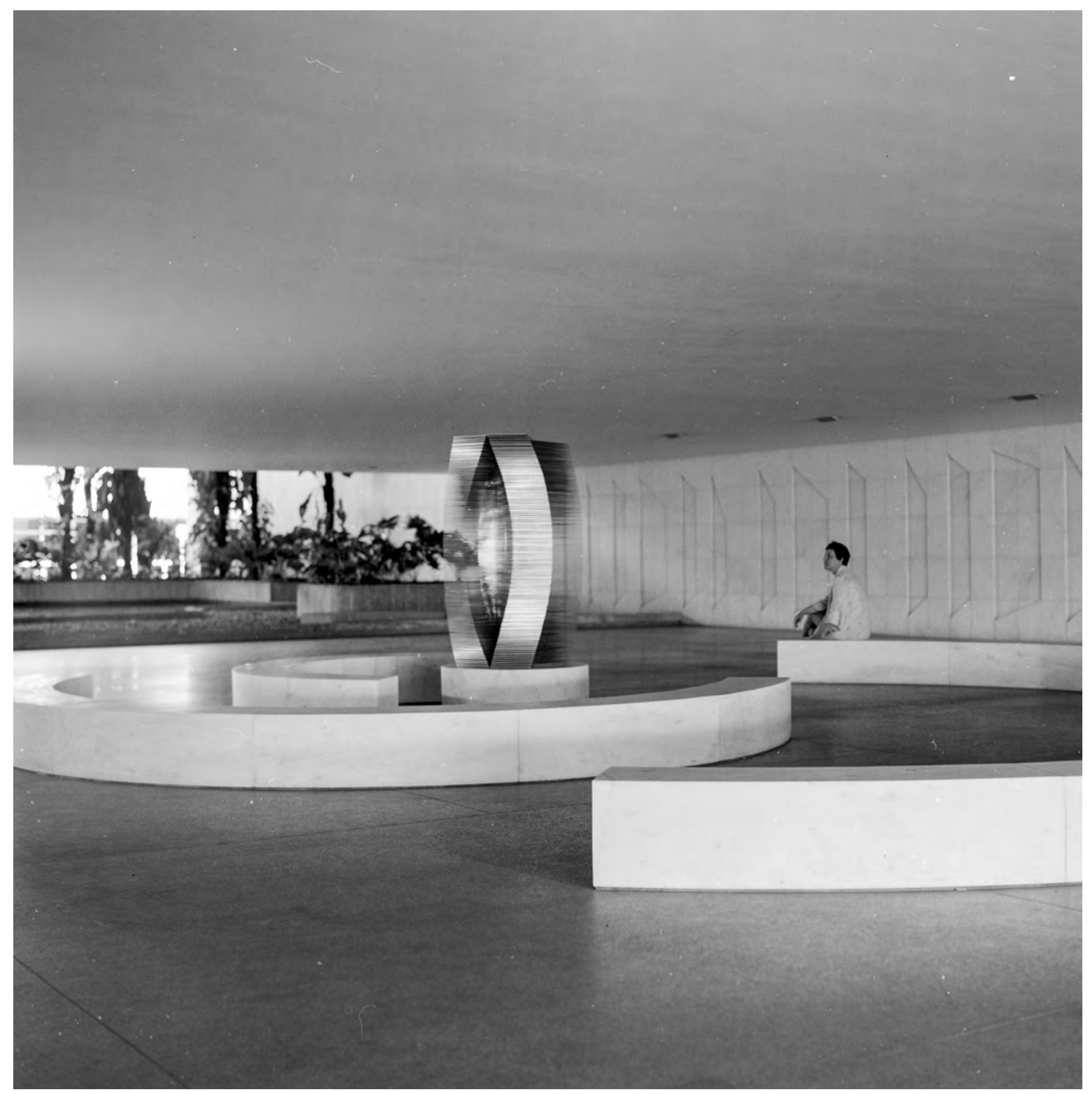

Figura 58: "Polivolume: Ponto de Encontro" - Mary Vieira, Marcel Gautherot, c.a. 1970. Fonte: Instituto Moreira Salles. 


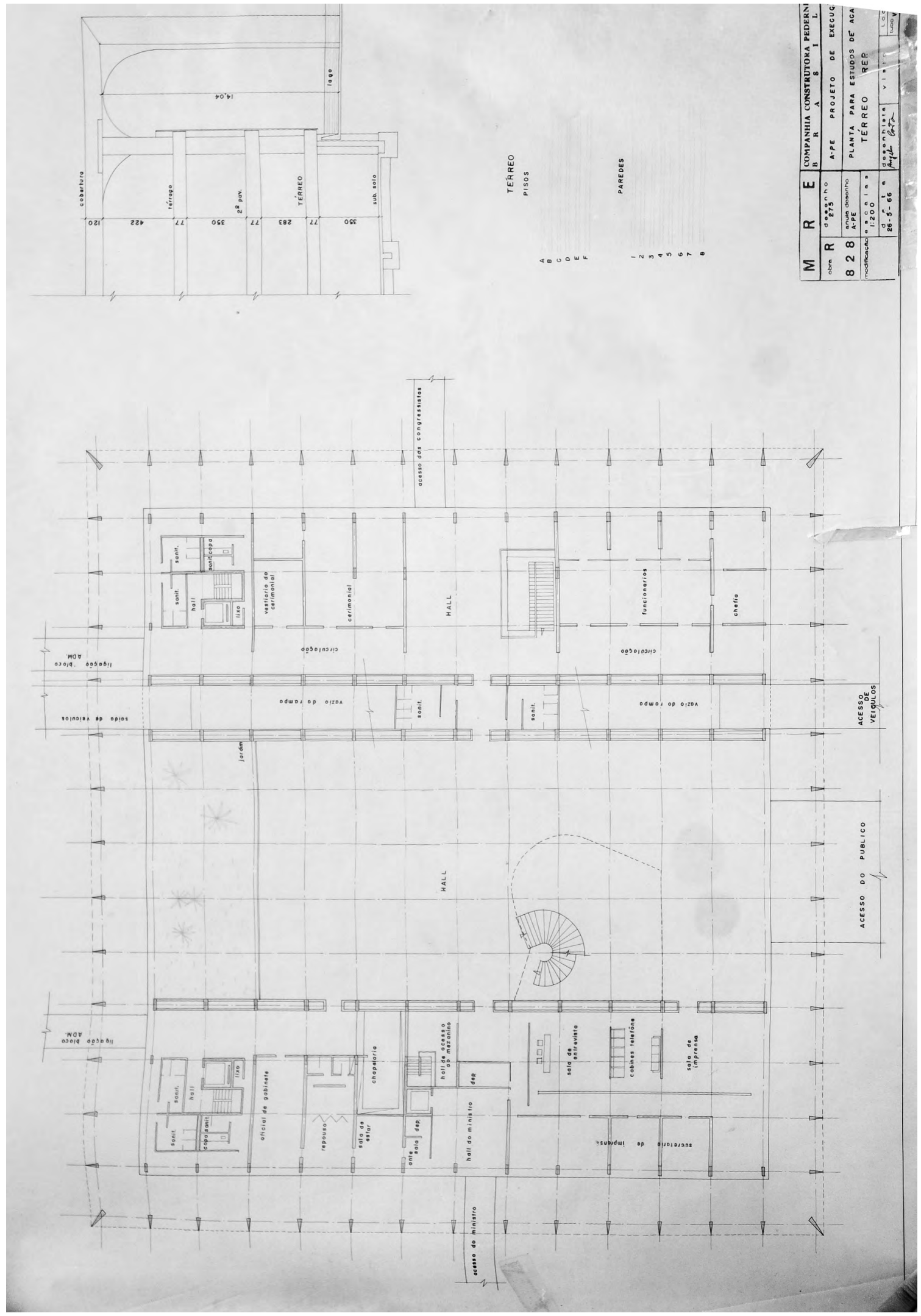

Figura 59: Planta para estudos de acabamento Térreo, 1966. Fonte: SARQ. 
O pavimento também conta com os ambientes administrativos: sala da imprensa, sala do cerimonial, salas de apoio, além do apartamento do ministro. Todos foram projetados em 1966. A planta quadrada do palácio foi dividida em 4 quadrantes e, assim, as áreas de todos os pavimentos foram pensadas a partir desses quadrantes.

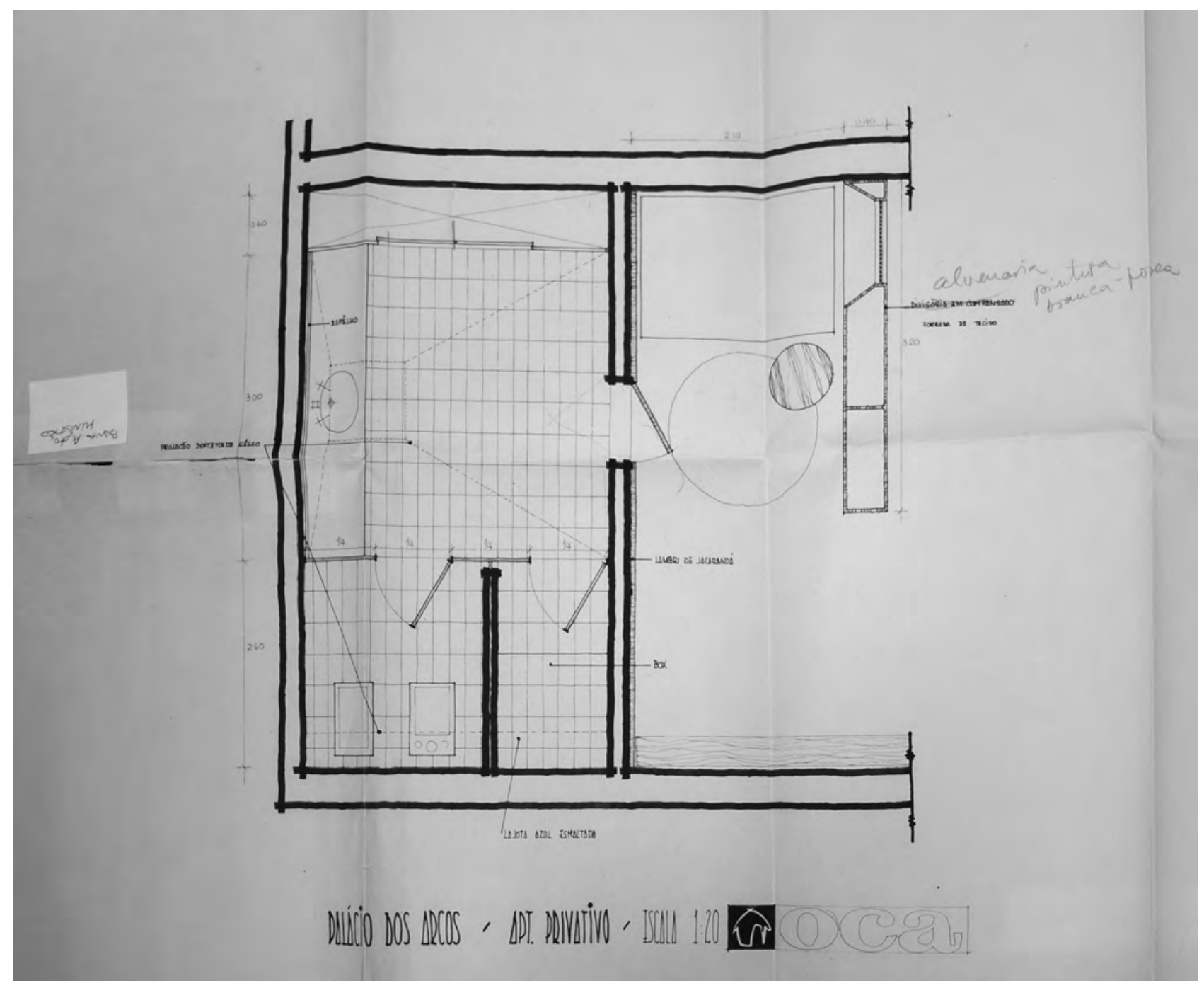

Figura 60: Apartamento privativo, Sergio Rodrigues, datação não identificada. Fonte: SARQ. 
O apartamento privativo do ministro foi ambientado por móveis da Oca, de Sergio Rodrigues, e alguns desenhados pela própria construtora, como é o caso dos armários. Não há indicações de obras de arte. Todo acesso dedicado ao ministro ocorre em corte e é privado: entrada, garagem, elevador para todos os pavimentos, apartamento, sala e entrada nos salões. Segundo Wladimir Murtinho:

Esse edifício, vejam bem, o San Tiago imagina ele em 61, quando todo mundo já achava enorme e gigantesco o que nós tínhamos, mas ele imaginou isso e, fez também uma outra ideia muito curiosa que é necessário ter um apartamento para ministro dentro do prédio. Ou seja, essas facilidades foram feitas por causa do San Tiago que sugeriu, elas existem no andar térreo, o ministro tem um lugar onde pode receber pessoas sem entrar no palácio. É uma ideia só, ele dizia: 'Não, há muitas pessoas que o ministro político precisa receber e que não merecem entrar no palácio.' Então ele disse: ‘É preciso ter.' Então, a partir daí, nós imaginamos essas facilidades que existem no andar térreo e que ninguém vê, e que aliás ninguém esteve. Vou lhe dizer uma coisa, isto é também uma das características do palácio, única também, é que ao contrário dos outros, só existe uma entrada para o ministro, que só ele usa. Ou seja, nós temos pelo ministro uma reverência total, e é aí, nessa entrada do ministro; tem três entradas: tem a entrada que chamemos assim, do público que é pela frente, não? Você tem a entrada do cerimonial e tem a terceira que é a do ministro. O ministro é uma pessoa que tem acesso a tudo, então ele tem acesso a esse apartamento que ninguém vê, tem muitos funcionários que jamais suspeitaram que existisse essa sala, porque está tão recolhida que, e, é, ele recebe a pessoa sem ser vista, ela tem acesso pela garagem, se quiser, mas tem acesso pela porta principal e tem acesso então a uma prumada de elevadores que é o máximo da sutileza, que leva ao gabinete, e também ao centro de convenções. (MURTINHO, 1990, p. 12)

Também foram adquiridos "móveis modernos", sem autor identificado, conforme consta no Relatório de Despesas de Wladimir Murtinho, para ambientar o apartamento do ministro. 
Há três entradas no térreo: a entrada principal, no Eixo Monumental, para os convidados do governo; a dos congressistas, utilizada pelo público geral, e a entrada do Ministro. Ao passar pelos planos de vidro de cor fumê, o visitante está no hall de recepção. É uma pausa que convida a olhar ao redor. Não há pilastras de sustentação no hall, isto é, não há ruído visual. À direita, a parede de mármore elaborada por Athos Bulcão com seus quadriláteros ritmados; à esquerda a escada helicoidal desenhada pelo arquiteto Milton Ramos. A escultura Polivolume: Ponto de Encontro de Mary Vieira. Ao fundo, o jardim de Burle Marx.

A partir da necessidade do vazio do hall para o cerimonial diplomático, o espaço é experimentado com uma relação vertical e helicoidal entre as partes. O painel de Athos Bulcão cria uma linha de profundidade ao pavimento que, ao encontrar o jardim interno, faz o nosso olho subir, já que a altura da vegetação avança ao Segundo Pavimento. O movimento da escada helicoidal aumenta com o recorte também circular da laje acima e dialoga com o movimento circular da escultura de Mary Vieira, terminando nas placas de alumínio ortogonal, tais como Relevo em Mármore de Athos Bulcão. Em uma relação continua entre as partes. Cria-se também um diálogo entre o Polivolume: Ponto de Encontro, de Mary Vieira - objeto dinâmico e interativo - assim como Burle Marx nos convida a interagir e usufruir da pintura, tornando-a tridimensional, pelo paisagismo.

Relação que também ocorre internamente e externamente: ao entrar, olhamos para ojardim que se abre para exterior; ao subir a escada, nosso olho está ora dentro em alguma obra, ora fora, olhando para o Eixo Monumental.

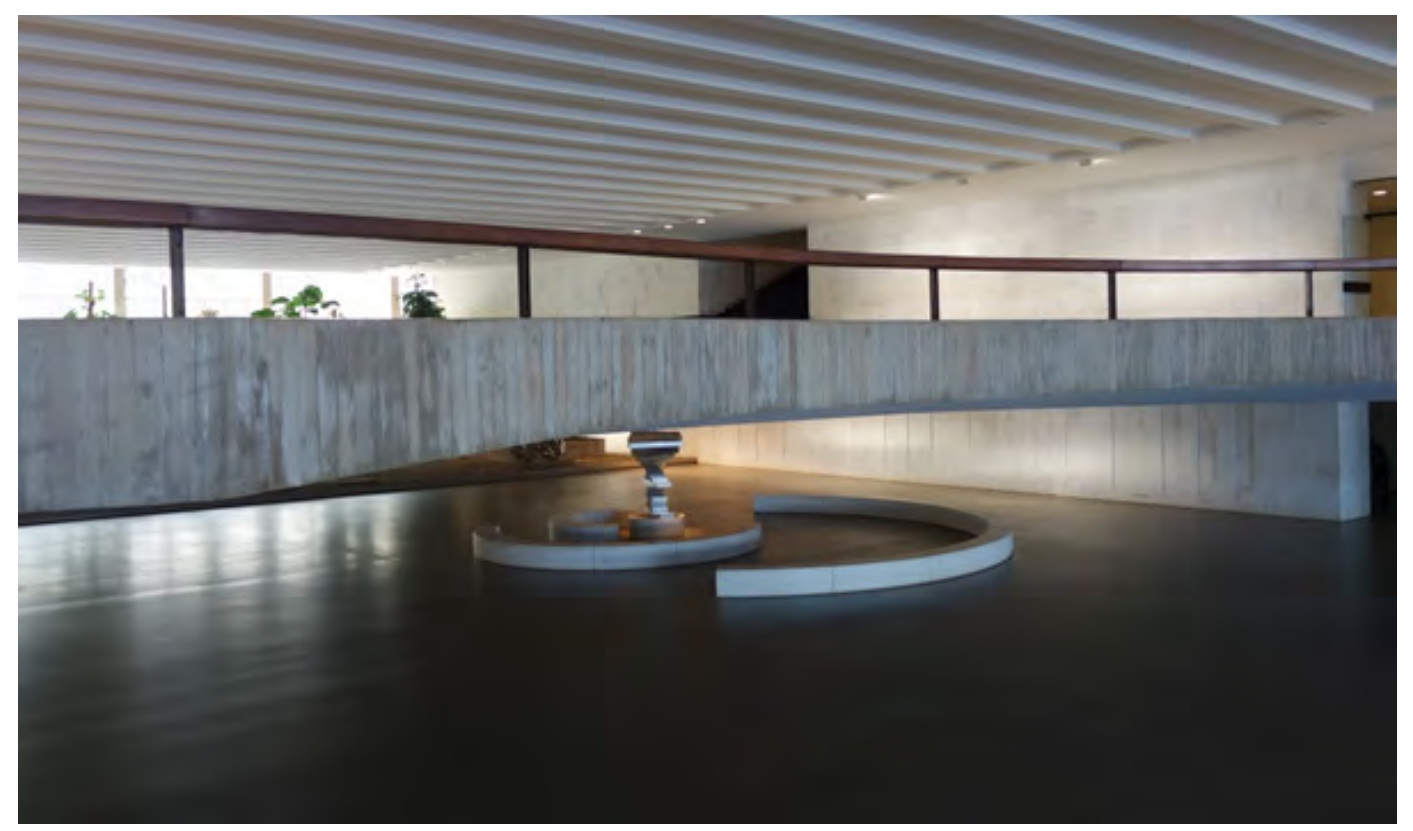

Figura 61: Vista da escada helicoidal. Fonte: Karen Matsuda, 2019. 


\subsection{SEGUNDO PAVIMENTO}

CORTE TRANSVERSAL: INDICAÇÃO ESQUEMÁTICA DO PAVIMENTO 
"Você ronda as salas paralelas e encanta-se com os móveis, execução de artistas brasileiros, e a decoração que obedece a um estilo que marca presença da vida brasileira em toda a sua história, desde o descobrimento. Passa-se para o grande salão. Uma imensa rampa de acesso que dá continuidade a um túnel onde trafegam os carros diplomáticos, corta o palácio de frente a fundo, desembocando na ala administrativa. Do salão, você se encontra com uma escada coberta por um tapete azul.." 44

Dúlio de Almeida 


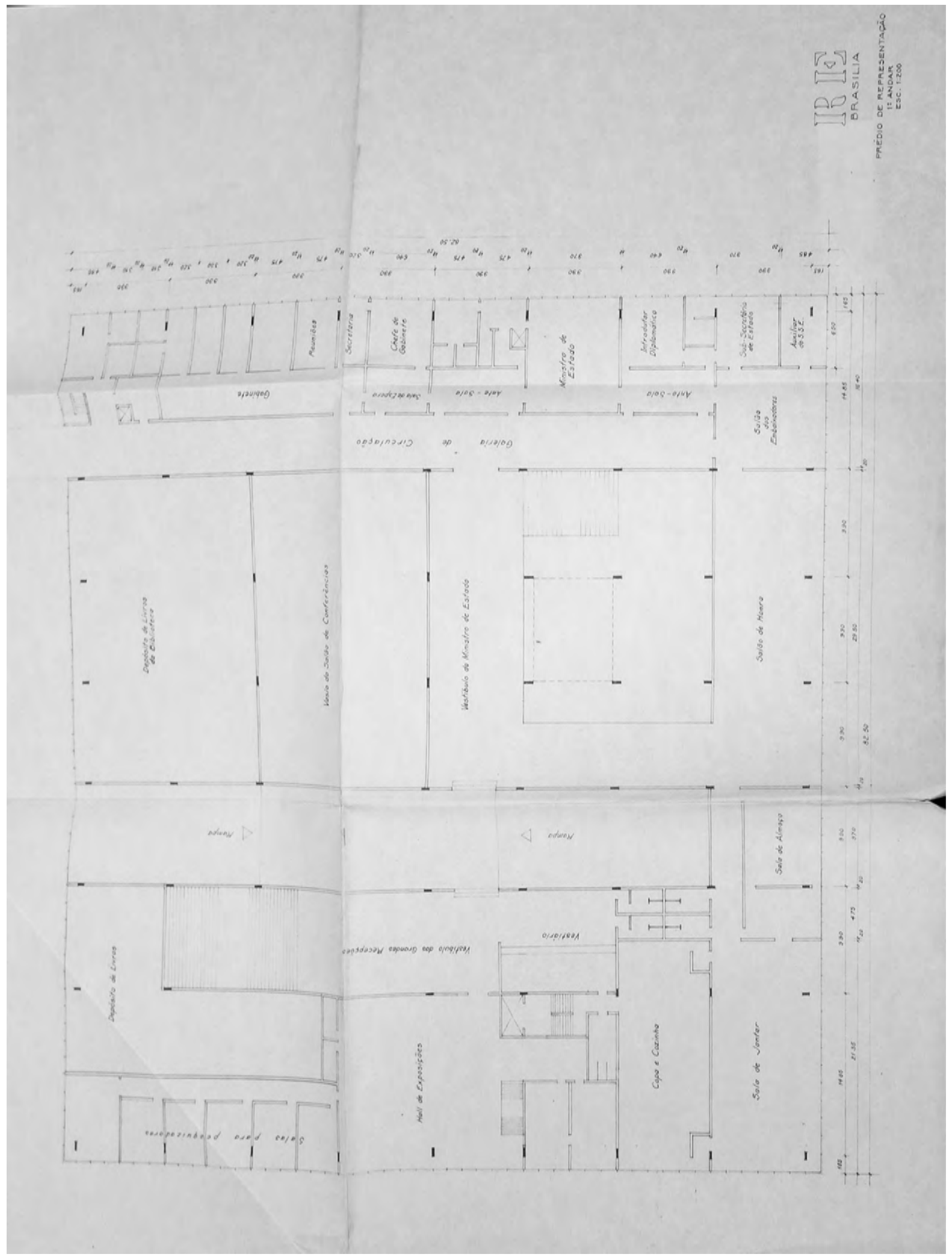

Figura 62: Prédio de Representação - $1^{\circ}$ Andar, datação não identificada. Fonte: SARQ. 
O Segundo Pavimento é destinado aos serviços diplomáticos de gabinete. É o local onde ocorrem, sobretudo, reuniões e o trabalho de escritório.

No primeiro projeto arquitetônico e programa de necessidades, o primeiro andar ${ }^{45}$ era uma mistura dos programas dos quatro pavimentos atuais, com espaço para exposições, depósitos para livros, sala para o ministro e o secretário geral, além das salas de jantar e de almoço e cozinha (Figura 62) - atualmente esta parte da recepção encontra-se no Terceiro Pavimento. Havia também o Salão de Honra e o Salão dos Embaixadores voltados para o Eixo Monumental. O desenho da escada era retilíneo. Já neste projeto, o desenho da rampa para veículos que leva até o Segundo Pavimento está resolvido, registrado nos desenhos de 1960 (Figura 63), ou como era descrita em 1969: "Uma imensa rampa de acesso que dá continuidade a um túnel onde trafegam os carros diplomáticos, corta o palácio de frente a fundo, desembocando na ala administrativa." ${ }^{46}$

Em outro programa de necessidades mais próximo ao realizado, temos: a rampa de acesso e escadaria; grande vestíbulo, salão nobre, ante sala (2), sala de reuniões, sala dos embaixadores, introdutor diplomático; Ministro de Estado: entrada e elevador privativo, salas de espera (2), gabinete de trabalho, sala de repouso, cabine telefônica, banheiro, sanitário, copa; Gabinete: sala de espera, chefia, funcionários: salas (3), sanitários, copa; Cerimonial: sala de espera, chefia, reuniões, subchefia, funcionários (3), vestiário, banheiro, sanitários; salão dos embaixadores da república e serviço de relações com o congresso: copa, sanitário, elevadores comunicação com o prédio administrativo. O programa define o pavimento como a área destinada aos serviços diplomáticos de gabinete. Retirando, assim, os espaços destinados aos banquetes, aos salões e às exposições.

45 O nome atual é Segundo Pavimento. Neste projeto, o segundo pavimento é nomeado como Primeiro Andar.

46 ALMEIDA, Duílio de. O que ver no Itamarati, Jornal Correio Braziliense, Brasília, 19 de abril de 1969, Caderno 2, p. 13. 


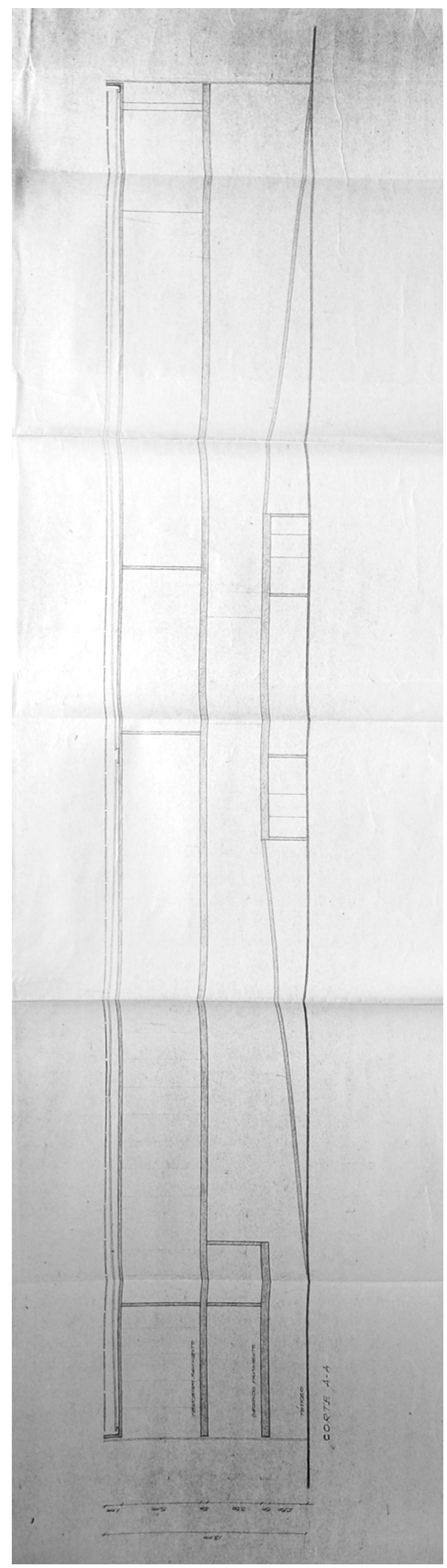

Figura 63: Corte A-A, Novacap, 1960. Fonte: SARQ. 
4. OS ESPAÇOS PALACIANOS / 127

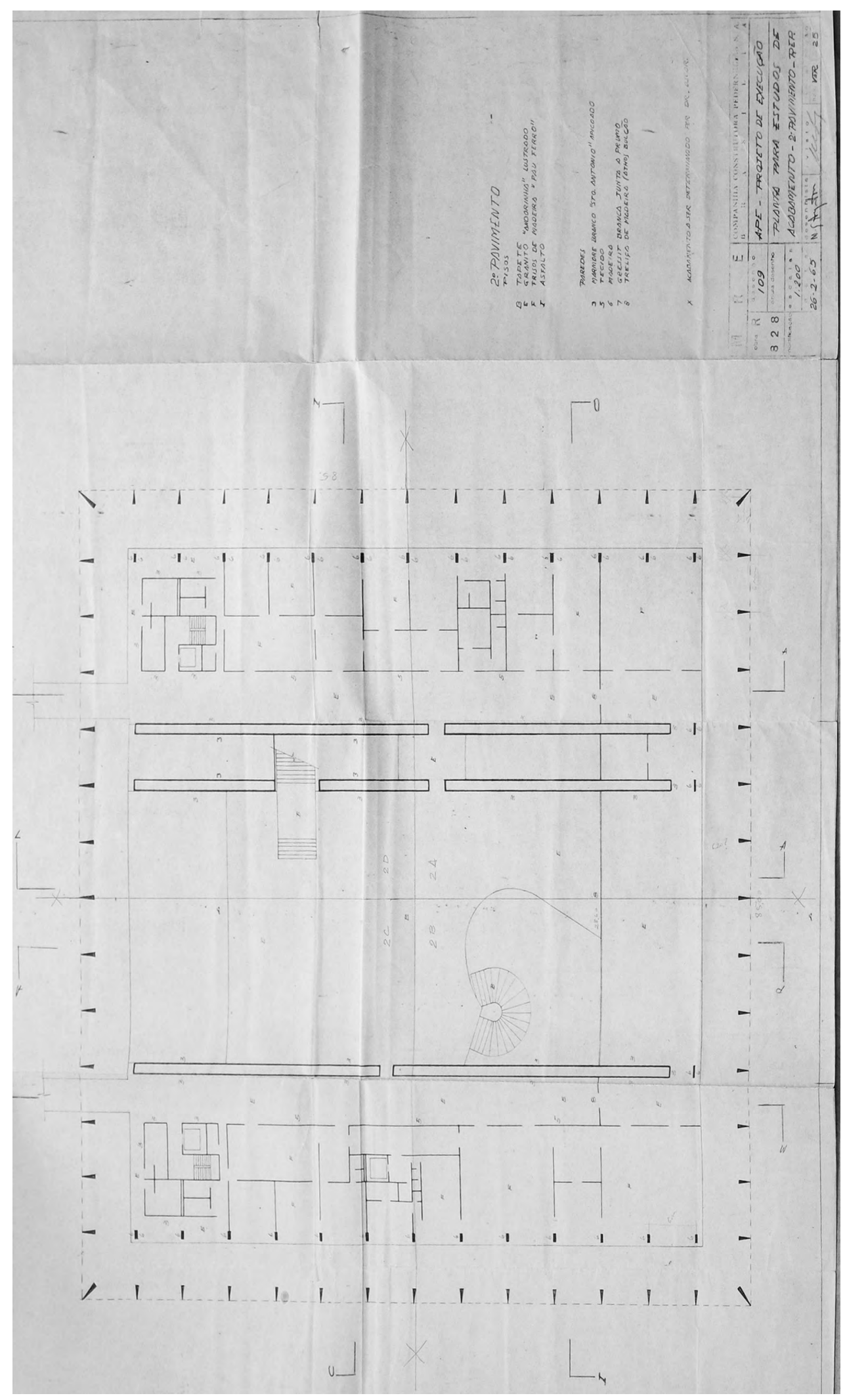

Figura 64: Planta para estudos de acabamento $2{ }^{\circ}$ Pavimento, 1965. Fonte: SARQ. 
No início de 1965, com o desenho da escada helicoidal já definido, o pavimento ganha a forma atual e a sinuosidade nos limites da área central da laje (Figura 64). A distribuição do programa ocorre em três seções longitudinais paralelas: nas extremidades, há as salas destinadas aos trabalhos de escritório; ao centro, o Salão de Honra e as escadas - áreas destinadas ao cerimonial. Neste momento, o pavimento ganha também o caráter de transição entre o térreo e os salões. Como nos demais pavimentos, o projeto é pensado em 4 quadrantes.

No projeto de meados de 1966, uma extremidade destina-se ao gabinete do Ministro; a outra, ao do secretário-geral, como explica Murtinho:

(...) porque nós na realidade, repetimos a solução que havia sido adotada no Rio de Janeiro, para o palácio propriamente dito. O palácio no Rio de Janeiro é um quadrilátero a semelhança deste, e tem duas alas: em uma está o secretário-geral, com todo o seu secretariado, e do outro está o ministro de Estado, com o gabinete, e isso foi o que nós fizemos aqui. Quando a pessoa encontra e acha aquilo muito natural, é porque nós já tínhamos testado este sistema, durante 60 anos. De maneira que tínhamos muita experiência no assunto... Quando se fez aqui, a característica está em que, ao contrário de todos os ministérios e aqui inclusive do Planalto, é o ministro nunca está ao lado do secretário-geral. E não está ao lado por causa de uma velha tradição que dizem que o secretário-geral, não deve ficar demasiado perto do ministro, para terem tempo de pensar, quando é chamado como é que ele vai explicar o assunto. Esta é uma velha teoria de um antigo secretário-geral, que montou toda a parte administrativa... que era Maurício Nabuco. Ele inventou essa ideia, não? Eu usei esta ideia também e por isto vocês verão que o ministro, ao contrário de todos os ministérios, está afastado por exatamente 60 metros. Esse corredor, este leva de um lado a outro, tem 60 metros, não? Que é o Salão dos Tratados. Então o ministro, o secretário-geral sai da sua sala e invés de entrar direto no gabinete do ministro, atravessa uma grande galeria onde você tem três bustos dos diplomatas que caracterizaram a tradição do Itamaraty. (MURTINHO, 1990, p. 4) 
4. OS ESPAÇOS PALACIANOS / 129

A princípio, o ambiente central da planta voltado para a Eixo Monumental era chamado de Salão de Honra. Torna-se o Salão Nobre, como se vê no projeto de 1966 (Figura 66), com uma divisória com portas que o separa do hall. Salão Nobre também é o nome do salão principal destinado às recepções no palácio do Rio de Janeiro. Ao lado do Salão Nobre, onde hoje está o afresco de Alfredo Volpi (Figura 70), havia uma copa com a entrada oculta por uma parede revestida em pau-ferro (Figura 66).

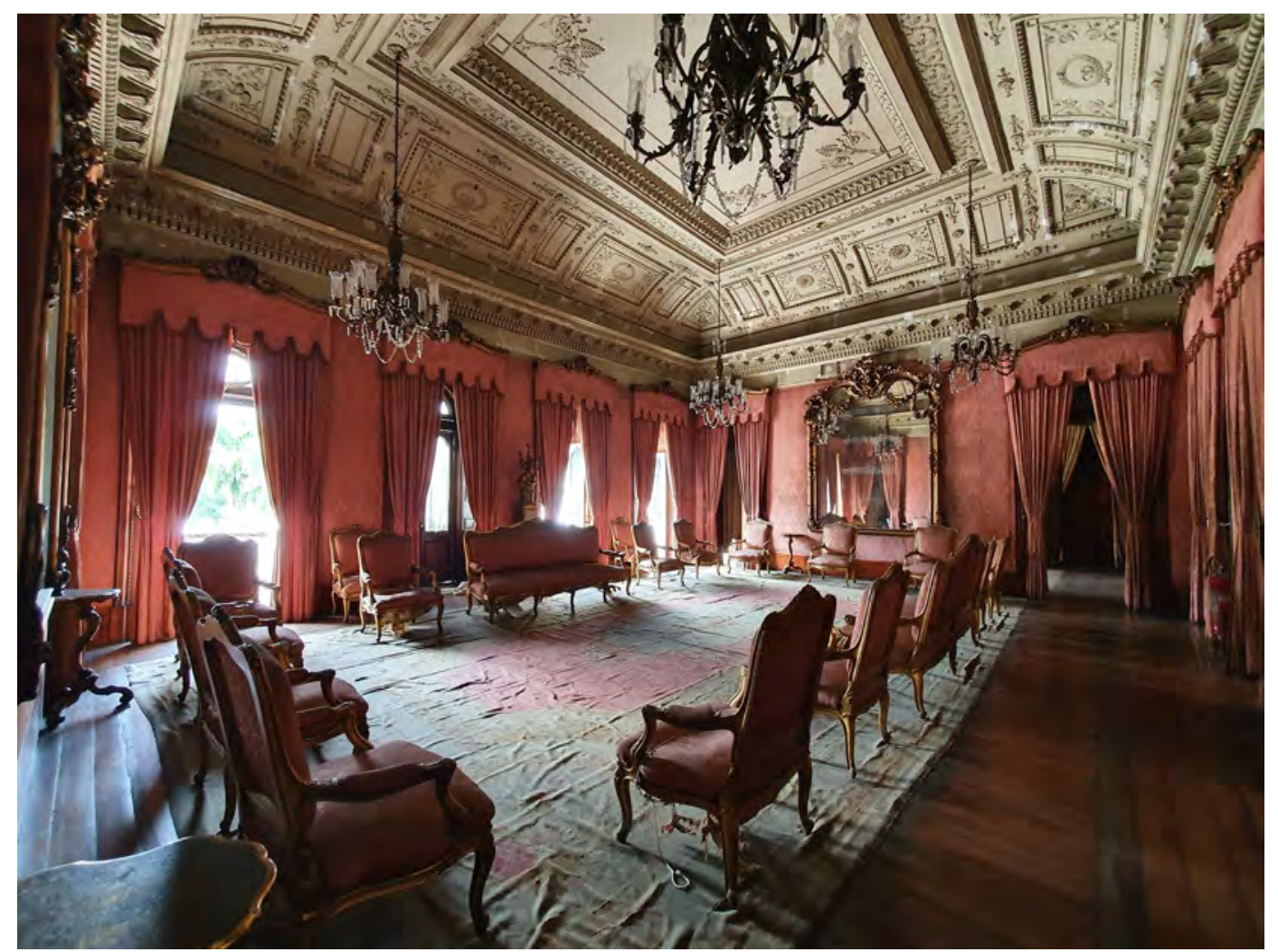

Figura 65: Salão Nobre, Palácio Itamaraty, Rio de Janeiro. Fonte: Karen Matsuda, 2020. 
Nas Figura 66 e Figura 67, sem datação, os layouts dos escritórios já estão definidos. A área de trabalho de cada funcionário era delimitada pelo uso de tapetes. O Salão de Honras torna-se a Galeria dos Tratados, permanecendo a divisória que a separava do hall, mas as portas foram retiradas (Figura 67). Há a indicação de mesas-vitrines, desenhadas por Sergio Rodrigues, que abrigariam os documentos históricos do Ministério das Relações Exteriores. Também três bustos estão dispostos pelo ambiente: "Tem o Alexandre de Gusmão, tem o primeiro embaixador nosso [Duarte da Ponte Ribeiro], no Peru e finalmente, especialmente, o Rio Branco. O Rio Branco está dando, preparando as costas para o ministro.” (MURTINHO, 1990, p. 4)

Este salão apresentou três soluções. Uma com os bustos lado a lado, as mesas-vitrines próximas ao vidro da fachada e a saída do corredor com duas cômodas. Outro, com as mesas-vitrines no hall e um busto de fronte aos outros dois. E uma sem os bustos e com as cômodas. Todos com uma mesa ou banquetas centralizadas no salão. Segundo o Relatório de Despesas do Murtinho, a Galeria dos Tratados contava com 3 mesas-vitrines, já citadas de Sergio Rodrigues, e 3 banquetas de 3 metros cada.

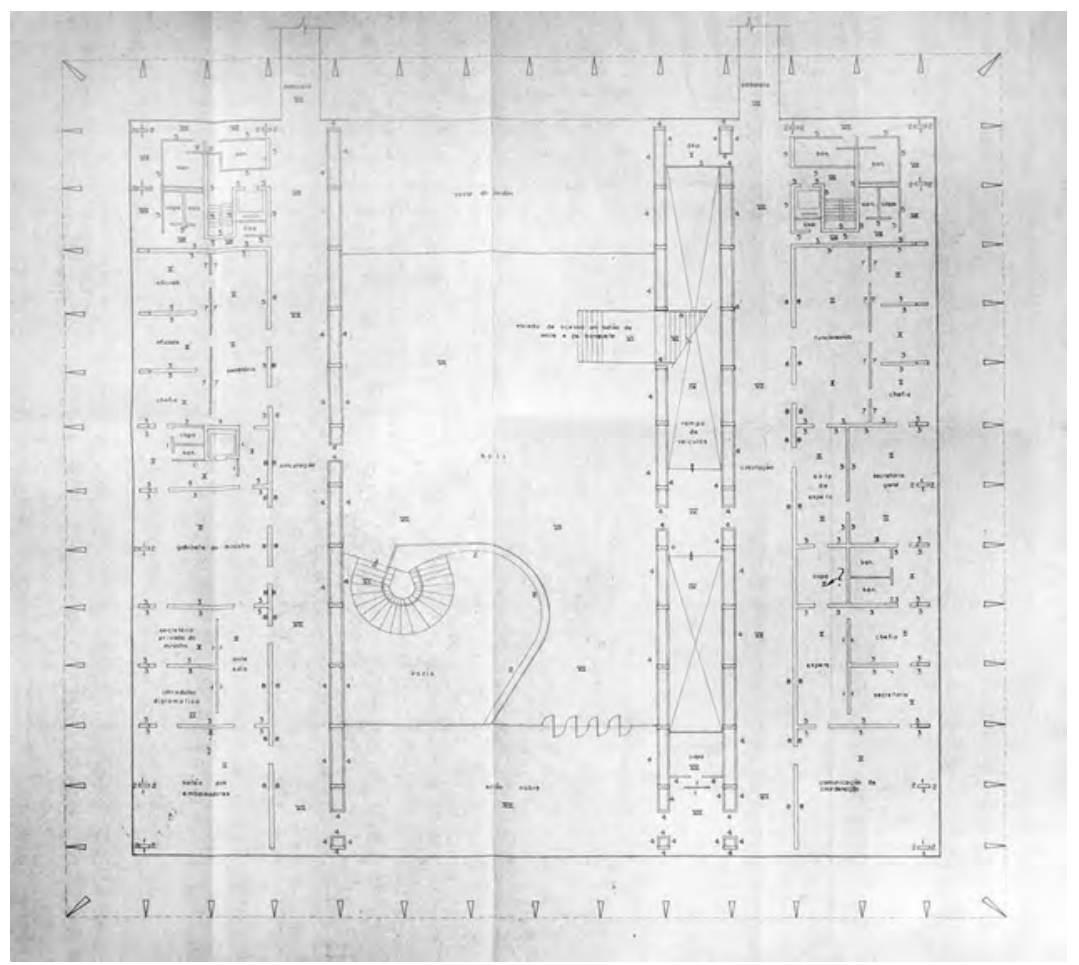

Figura 66: Bloco Representativo - 2 Pavimento, datação não identificada. Fonte: SARQ. 
4. OS ESPAÇOS PALACIANOS / 131

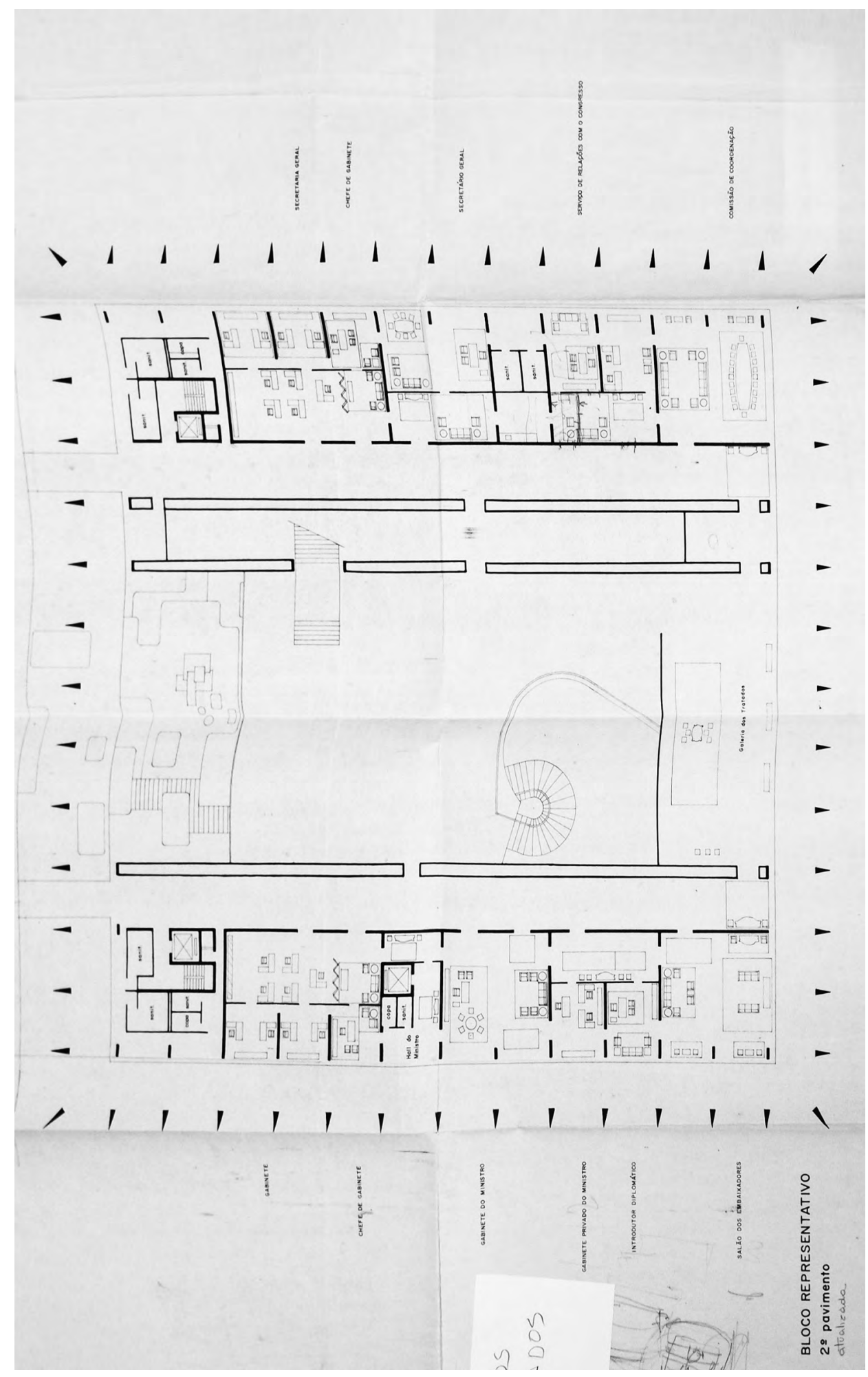

Figura 67: Bloco Representativo - 2 ○ Pavimento, datação não identificada. Fonte: SARQ. 


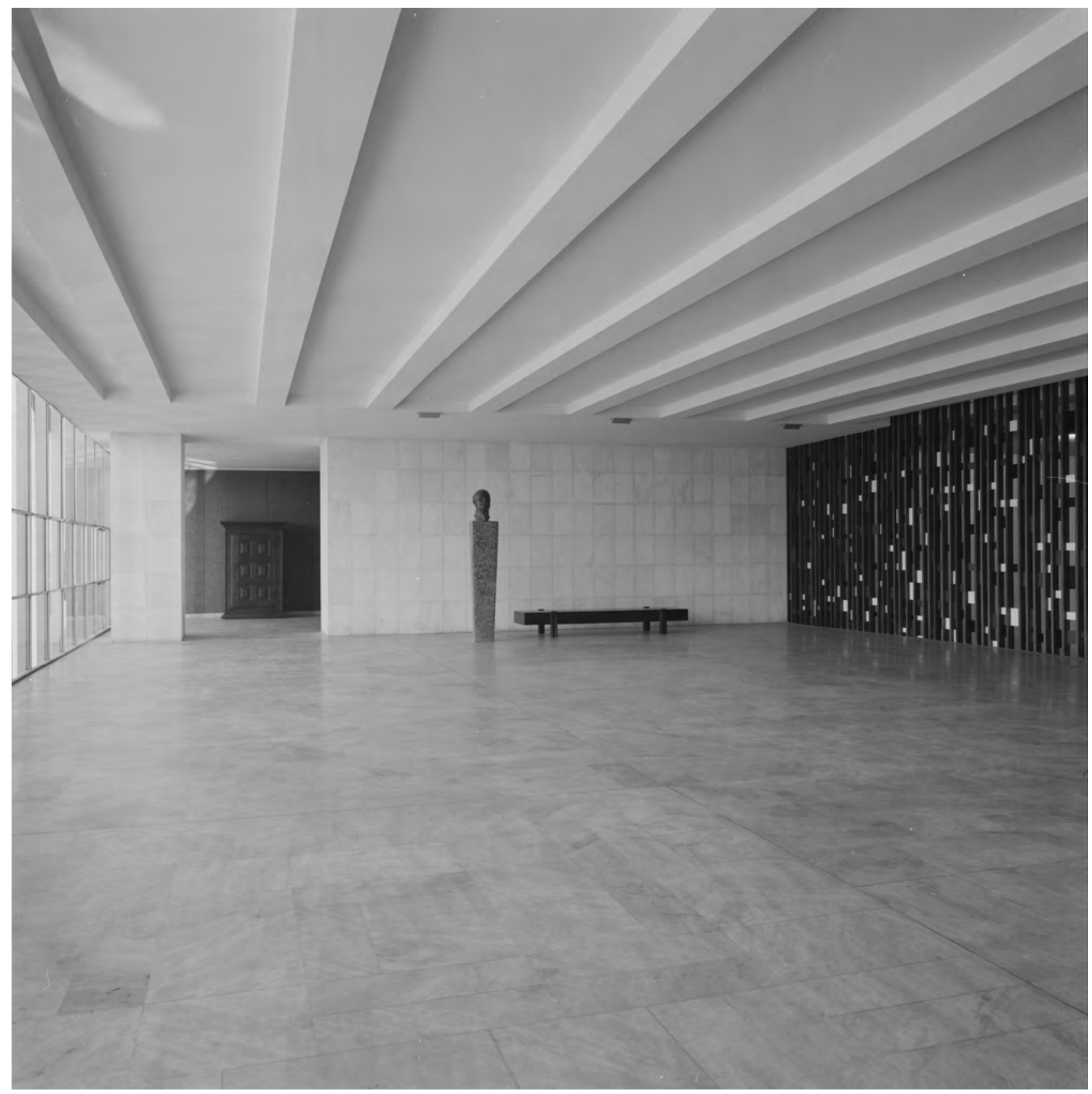

Figura 68: "Treliça”" de Athos Bulcão, Marcel Gautherot, 1968. Fonte: Instituto Moreira Salles. 
4. OS ESPAÇOS PALACIANOS / 133

Com a definição da Treliça desenhada por Athos Bulcão, conforme projeto elaborado pela Novacap em novembro de 1966, o espaço central do pavimento torna-se aberto. $\mathrm{O}$ desenho sinuoso da laje permite o diálogo com a escada helicoidal, de onde é possível olhar para o jardim do térreo e a para a Galeria dos Tratados, delimitada pela Treliça que parece pulsar pelo espaço.

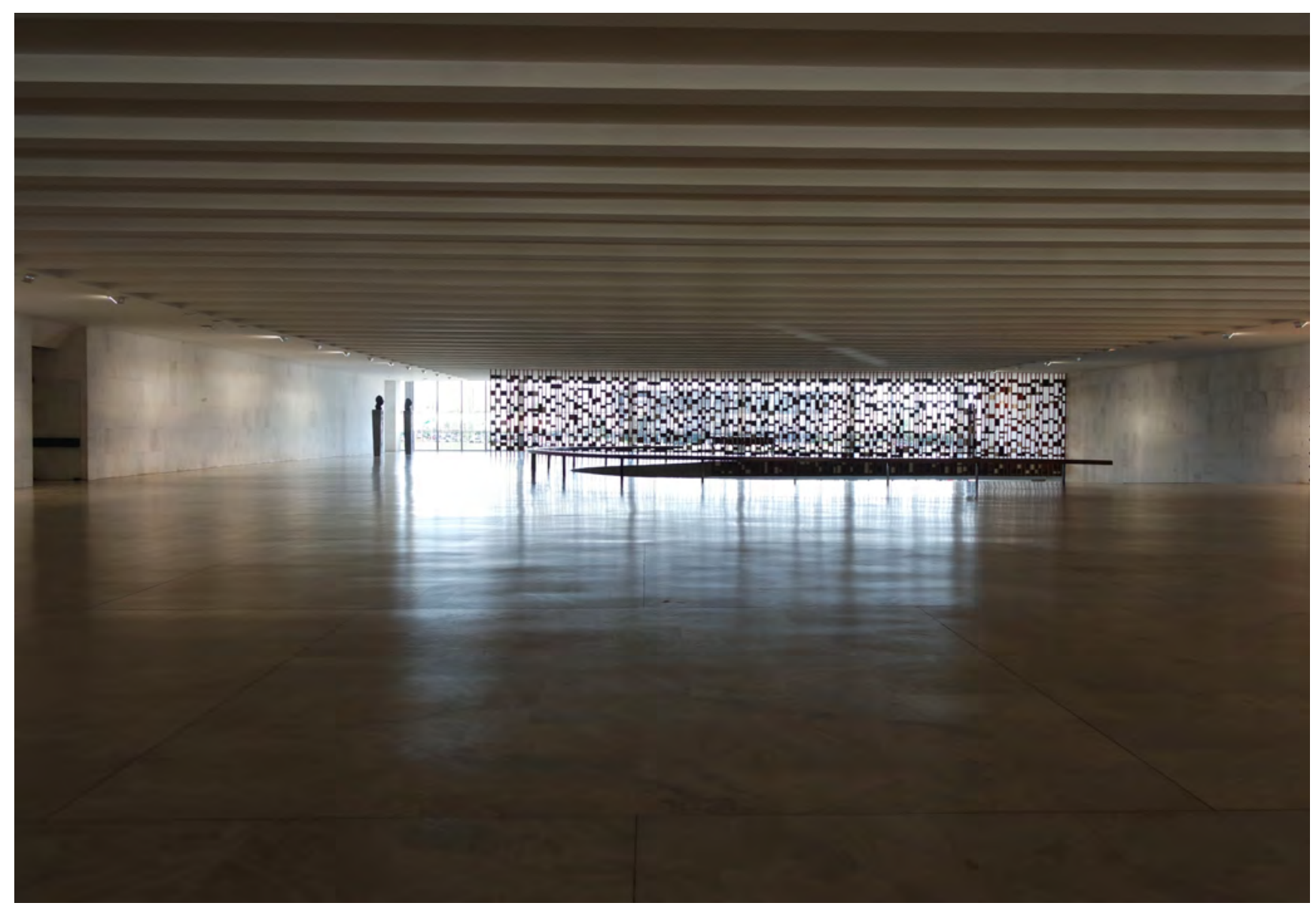

Figura 69: Segundo Pavimento. Fonte: Karen Matsuda, 2019. 
É só no projeto de junho de 1966 que aparece a indicação de um afresco na sala ao lado da Galeria dos Tratados, onde hoje está o afresco Visão de Dom Bosco, de Alfredo Volpi:

O afresco que mede 3,50 por 4,50 metros, tem campo azul, e a civilização está representada pelos triângulos nas cores pretas e vermelho róseo, circundado o cruzamento das duas linhas mestras que identificam, ao mesmo tempo, o ato de quem toma posse e o sinal da cruz, ponto inicial do Plano Lúcio Costa. Dom Bosco é a figura central da obra, representando o poder centralizador da fé. As tintas foram preparadas no local da obra, objetivando, o artista, uma tonalidade ideal. ${ }^{47}$

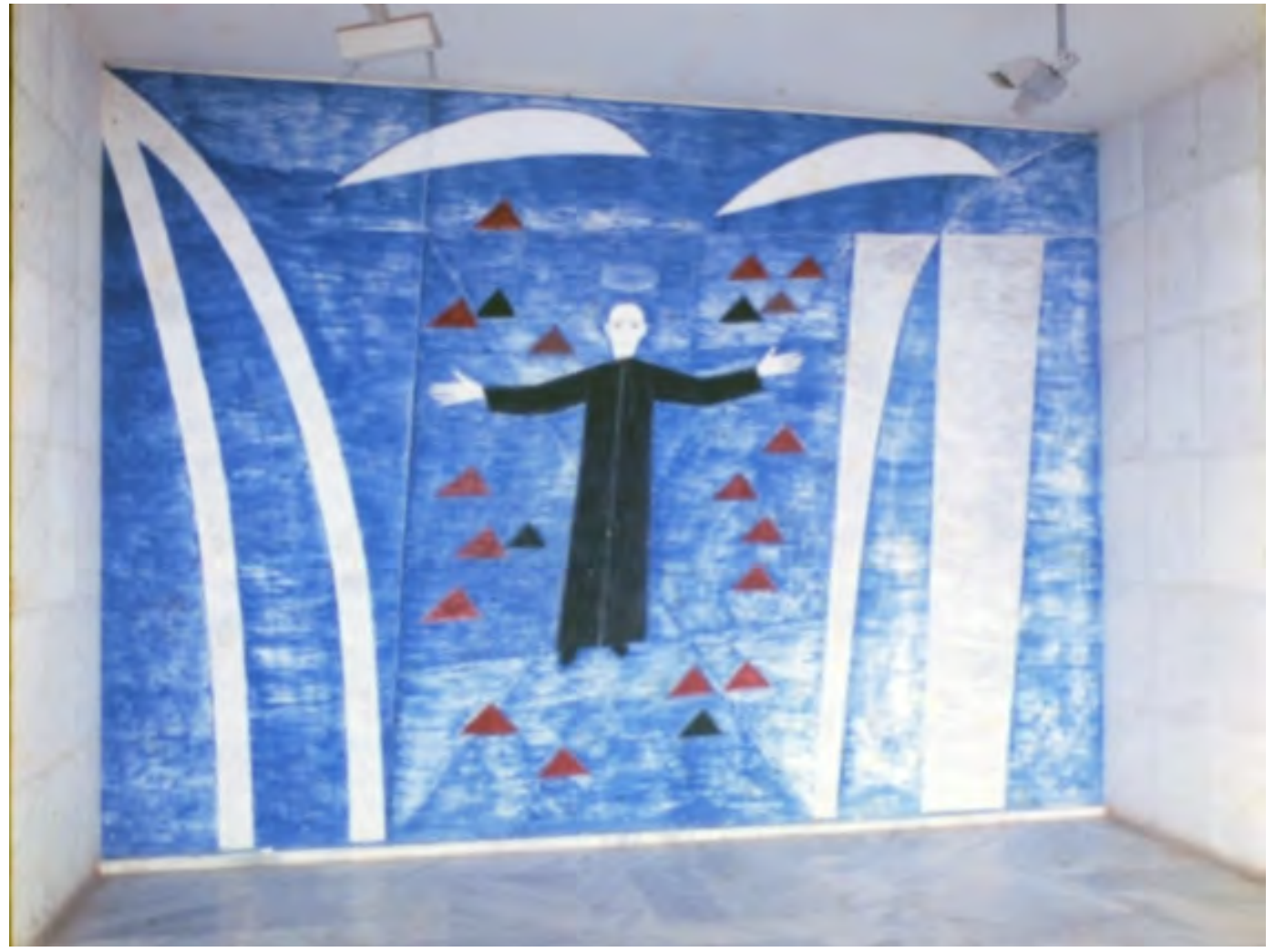

Figura 70: Afresco "Sonho de Dom Bosco" de Alfredo Volpi, Marcel Gautherot, c.a. 1966. Fonte: Instituto Moreira Salles.

47 Salões da Chancelaria prontos até o dia 15. Jornal Correio Braziliense, Brasília, 25 de fevereiro de 1967, p. 1. 
O piso do pavimento é de mármore branco Italva polido e as paredes são de mármore apicoado. Nos corredores, as paredes dos gabinetes são revestidas por juta na cor verde e as portas são com acabamento em pau-ferro. Assim, o Segundo Pavimento, conforme conta a matéria "O que ver no Itamarati", de 19 de abril de 1969, do jornal Correio Braziliense, é formado pelo "imenso salão ladeado por dois corredores, onde estão as salas: Ministro de Estado, Chefe de Gabinete, Introdutor Diplomático e Salão dos Embaixadores"48.

A sala destinada aos trabalhos do Ministro foi elaborada a partir de 1966. Sergio Rodrigues foi responsável por pensar o ambiente que é composto pela mesa do ministro e uma versão da poltrona Kiko em capitonê, desenhados especialmente para o palácio (Figura 71). O mobiliário tem como característica o formato retilíneo, certa austeridade e solidez. Como nos demais ambientes, cada setor da sala era delimitado por um tapete. Obras de arte também faziam parte do gabinete:

Abre a primeira porta e vê: Grito do Ipiranga, original de Pedro Américo, colocado atrás da mesa de trabalho do senhor Ministro. Em sua frente, uma tapeçaria de 1782. A sala está decorada com móveis do século XVIII e XVII. Um quadro de Guedes Pinto, primeiro enviado do Brasil junto a Santa Sé (Luzitano de 1832) chama bem a atenção. ${ }^{49}$

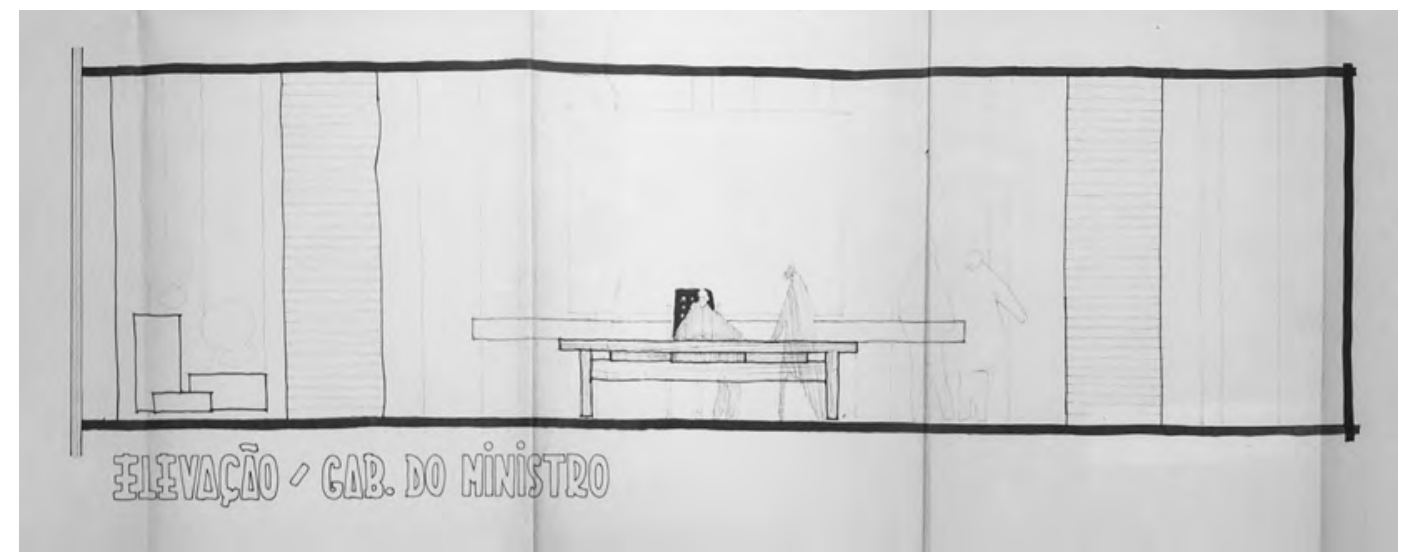

Figura 71: Elevação - Gabinete do Ministro, Sergio Rodrigues, datação não identificada. Fonte: SARQ.

48 ALMEIDA, Duílio de. O que ver no Itamarati, Jornal Correio Braziliense, Brasília, 19 de abril de 1969, Caderno 2, p. 13.

49 ALMEIDA, Duílio de. O que ver no Itamarati, Jornal Correio Braziliense, Brasília, 19 de abril de 1969, Caderno 2, p. 13. 


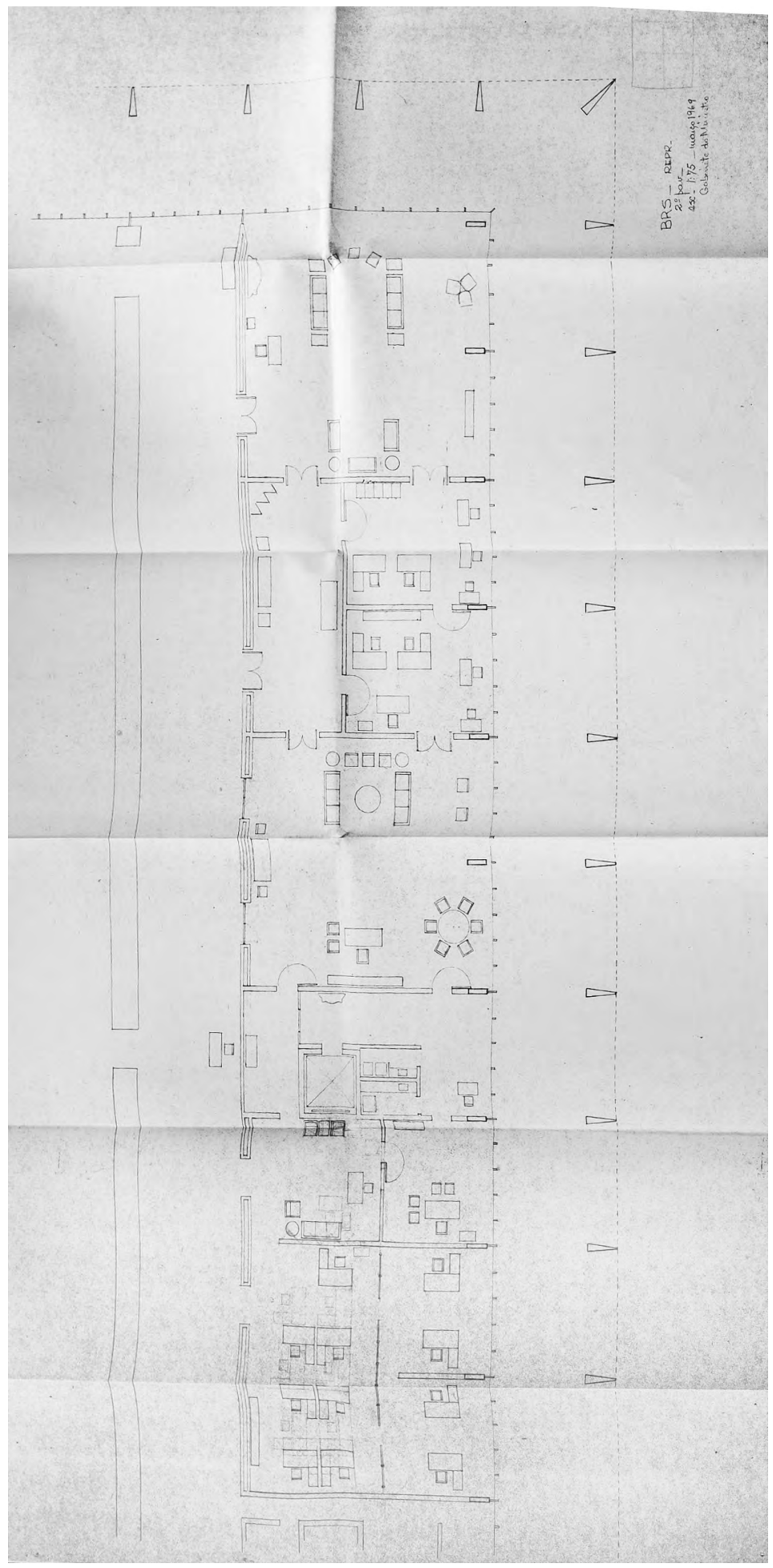

Figura 72: Gabinete do Ministro, 1969. Fonte: SARQ. 
A pintura histórica Grito do Ipiranga, de 1886, de Pedro Américo é uma representação da independência do Brasil. É, portanto, um quadro cuja imagem pretende criar uma memória do momento de fundação do Estado brasileiro (Figura 73). A tapeçaria de 1782, nomeada como Índios Pescadores, foi feita a partir dos desenhos de François Desportes que, por sua vez, se baseou nos cartões elaborados por Albert Eckhout (Figura 74). Foi executada pelo atelier Cosette et Fils e consta no Relatório de Despesas de Wladimir Murtinho como "Tapeçaria Aubusson, cartão de François Desportes, com motivos de flora e fauna imaginárias das colônias americanas. 1732."50

Ainda neste ambiente, temos Poltronas Kiko com espaldar alto e levemente reclinado, mesa com tampo de mármore e um sofá de veludo em capitonê verde. Todos projetados por Sergio Rodrigues. Em reportagem de Jean Clay sobre o palácio na revista Connaissance des Arts:

Quant aux meubles, ils ont été dessinés selon les exigences de la diplomatie. Les gens qui habitent les palais, explique l'ambassadeur Murtinho, sont souvent âgés. Si vous les asseyez sur du Mies van der Rohe, ils ne parviennent plus à se relever. Il faut aussi qu'on puisse leur parler à l'oreille ou leur traduire la conversation. Nos fauteuils sont donc cossus, confortables et sans recherche inutile. Sauf pour le salon de réception du ministre - où ils seront raides, incommodes, intimidants. On ne va pas chez le minister pour plaisanter. Il y faut un certain apparat..$^{51}$ (CLAY, 1968)

Outra reportagem do Correio Braziliense conta que no Gabinete do Ministro havia: "uma mesa holandesa, uma da Bahia de XVII, quadro de Guedes Pinto, O grito do Ipiranga, tapeçaria de 1882 de Wecauldt (sic), cadeira D. João V do século XVIII.” ${ }^{2}$

50 Relatório de Despesas - Resposta ao Requerimento de Informações n 4308, de 1968, pelo Embaixador Wladimir Murtinho.

51 Em tradução livre: Quanto aos móveis, eles foram desenhados segundo as exigências da diplomacia. As pessoas que vivem no palácio, explica o Embaixador Murtinho, por vezes são idosas. Se você os coloca numa Mies van der Rohe, não conseguem mais se levantar. Também é necessário que se possa falar-lhes ao ouvido ou traduzir-lhes uma conversa. Nossas poltronas são, portanto, confortáveis e sem rebuscamento inútil. Com exceção do salão de recepção do ministro - onde elas serão rijas, incômodas, intimidantes. Não se vai ao ministro para se divertir. É necessário um certo decoro.

52 ALMEIDA, Duílio de. Itamarati, o mais fabuloso palácio moderno do mundo. Jornal Correio Braziliense, Brasília, 07 de junho de 1967, p. 9. 


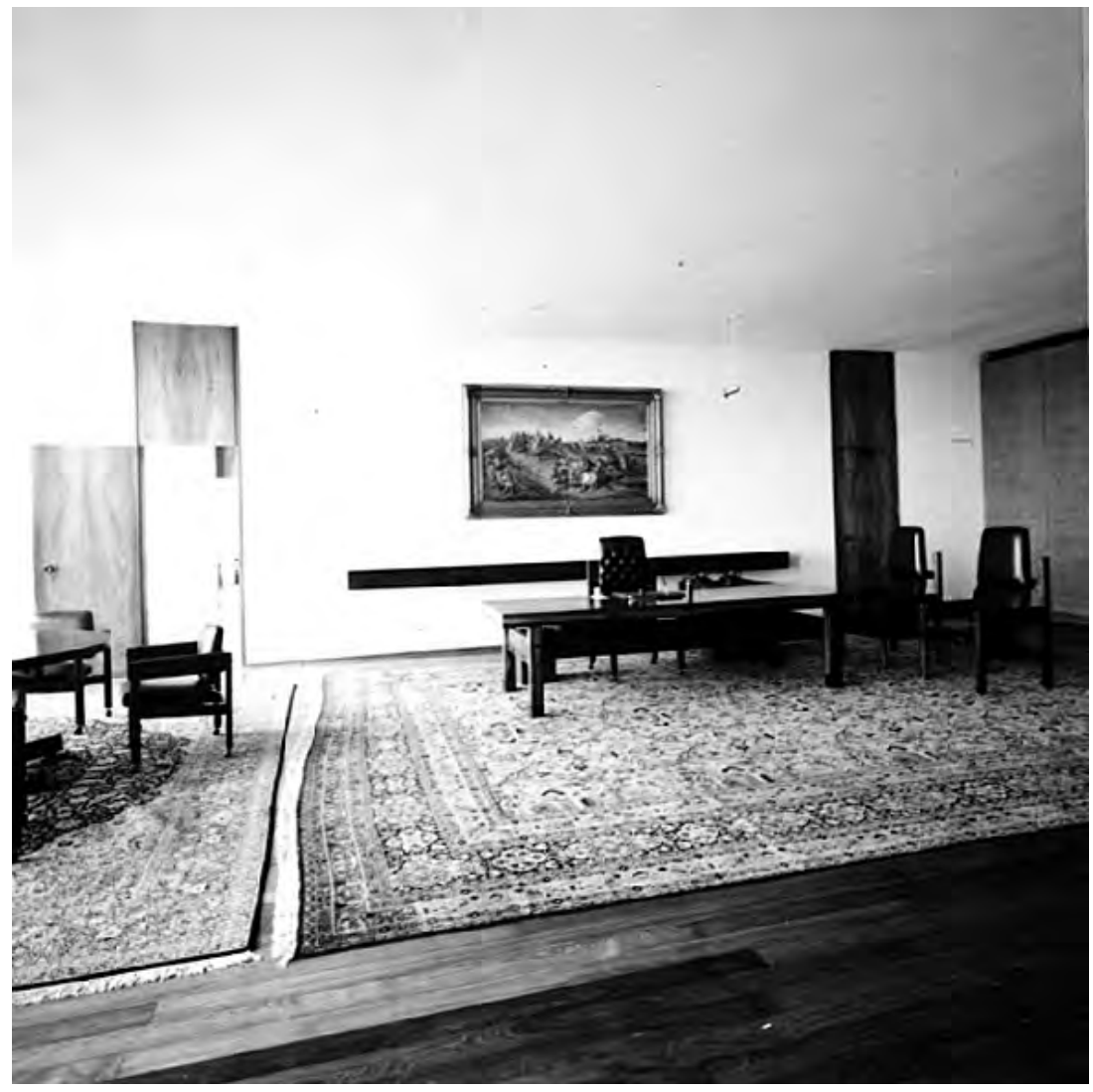

Figura 73: "Grito do Ipiranga", pintura de Pedro Américo, Marcel Gautherot, c.a. 1968. Fonte: Instituto Moreira Salles.

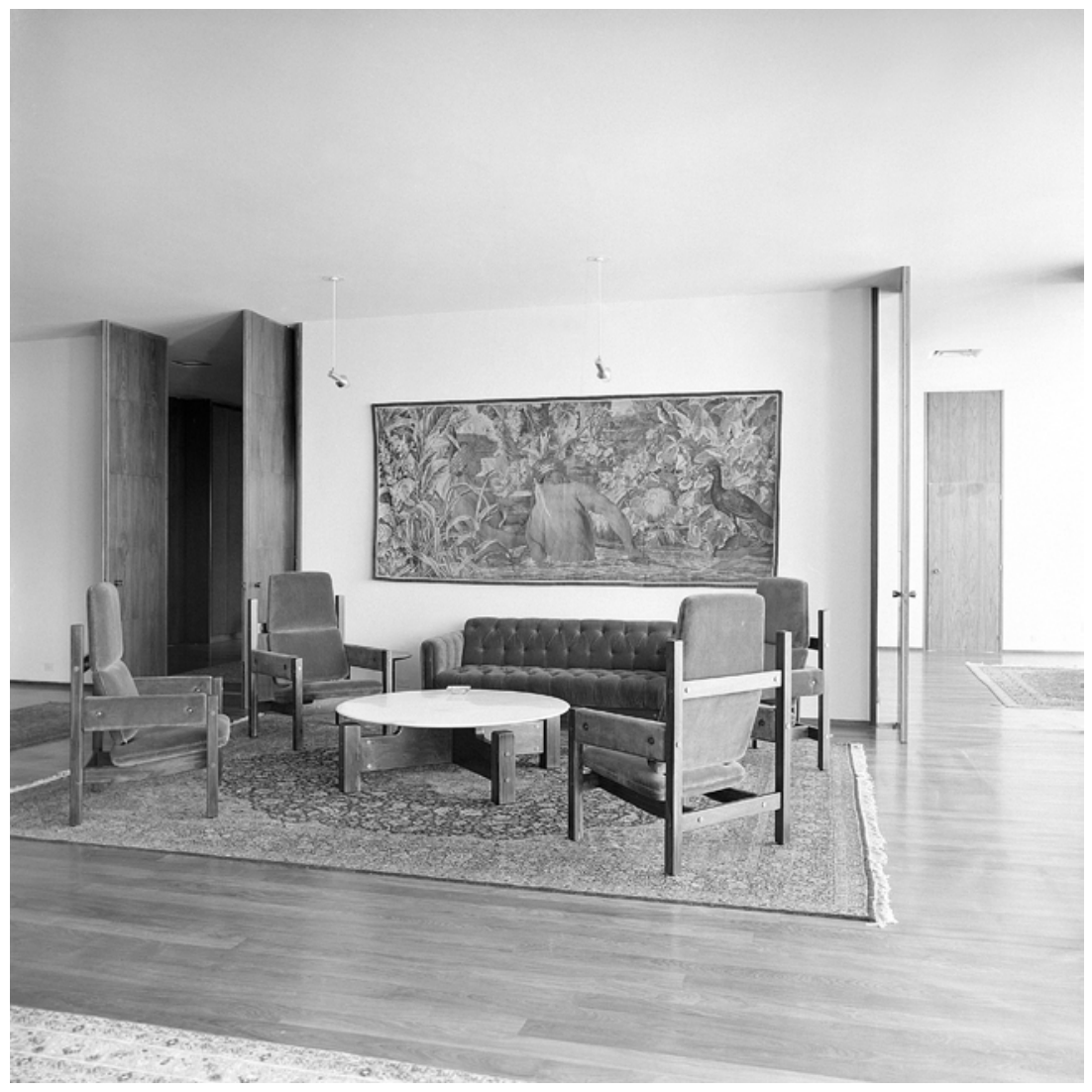

Figura 74: Tapeçaria "índios pescadores" e mobiliário desenhado por Sergio Rodrigues, Marcel Gautherot, c.a. 1968. Fonte: Instituto Moreira Salles. 
O quadro citado de Guedes Pinto, cônsul do Império do Brasil em Roma, foi pintado por Antonio Manuel da Fonseca, em $183^{53}$. A cadeira D. João V e a mesa Goiana constam no Relatório de Despesas de Wladimir Murtinho.

Embora Wladimir Murtinho contasse que:

Da mesma forma, o original do Guerra e Paz de Portinari está conosco. Porque esse foi um quadro, os painéis que estão hoje nas Nações Unidas, foram trazidos para cá, veja bem, em 1960, para decorar o gabinete do ministro, nós tínhamos um único gabinete decorado que havia aqui. Tivemos um incêndio, se perderam, se chamuscaram muito, depois foram restaurados admiravelmente. Estão hoje no gabinete do ministro. Guerra e Paz, porque é o que domina o Ministério das Relações Exteriores, então a guerra e a paz, não é? (MURTINHO, 1990, p. 16)

No entanto, uma reportagem sobre um incêndio que ocorreu no gabinete do ministro, que estava localizado temporariamente no Ministério da Saúde, conta que: "Chegou há poucos dias para adornar a residência do Ministro das Relações Exteriores o quadro "Guerra e Paz" de Portinari, vale cerca de 12 milhões de cruzeiros, teve as molduras parcialmente destruídas." 54 Nos demais documentos pesquisados, não há menção à obra, nem onde ela seria colocada no ministério. Muito provavelmente, no momento da inauguração do palácio, os estudos de Guerra e Paz, de Portinari, estavam no restauro.

53 Atualmente a pintura está no Palácio Itamaraty do Rio de Janeiro.

54 Violento incêndio destrói três pavimentos do Bloco 11 da Esplanada dos Ministérios. Jornal Correio Braziliense, Brasília, 15 de agosto de 1964, p. 8. 


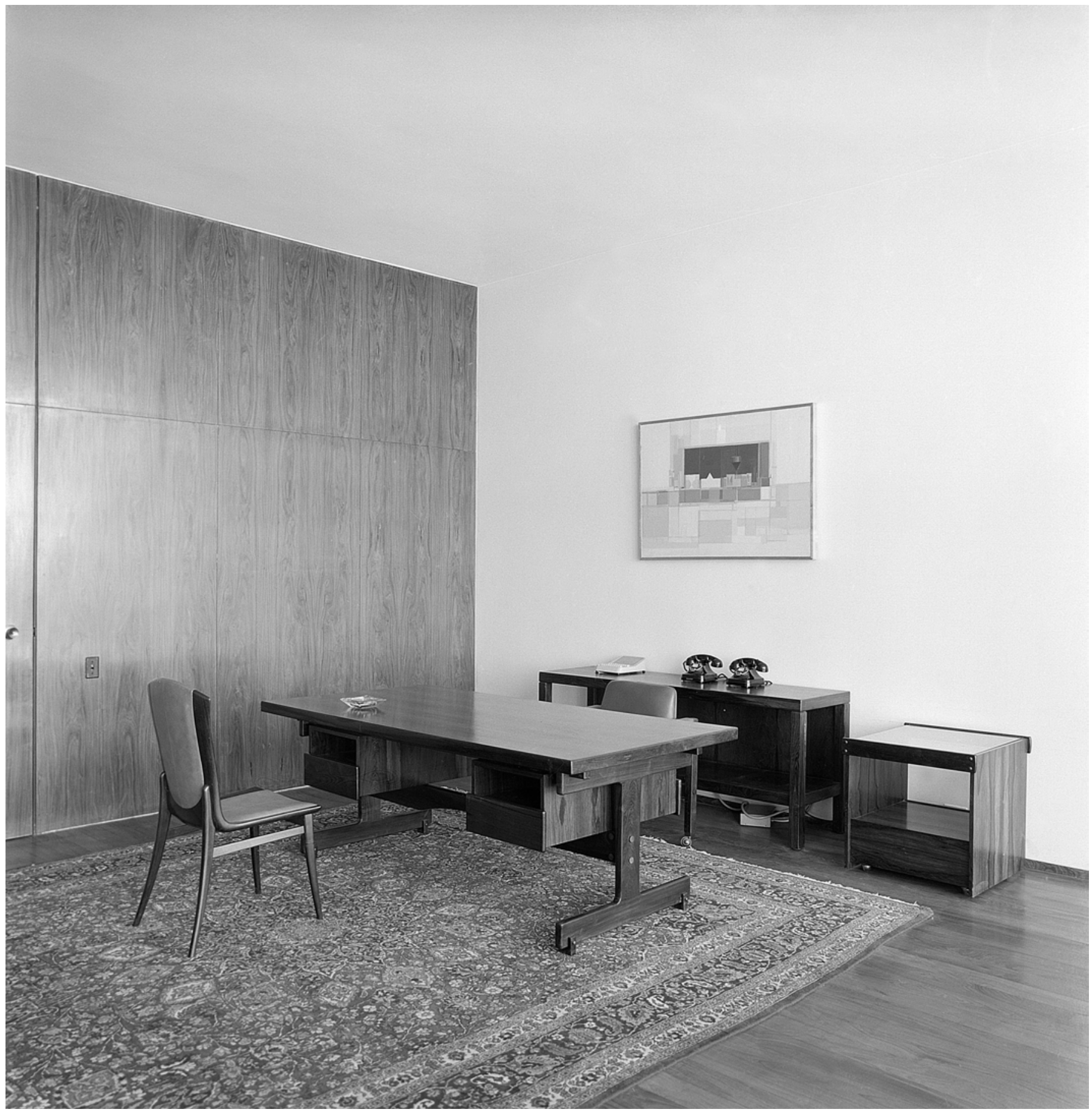

Figura 75: "Os episódios III", pintura de Maria Leontina, Marcel Gautherot, c.a. 1968. Fonte: Instituto Moreira Salles. 
Ao lado da sala do Ministro, temos a sala do Chefe de Gabinete em que "encontra-se um quadro de rara beleza de Milton Dacosta, para em seguida [na sala do introdutor diplomático] encontrar-se Maria Leontina, cujo trabalho lhe valeu prêmio Guggenheim." 55 (Figura 75).

Nesta sala, além de Os episódios III ou Jogos - como era nomeado no Relatório de Despesas de Wladimir Murtinho - de Maria Leontina, temos mesa, estante e carrinho da Oca, desenhados por Sergio Rodrigues e Cadeira dos Arcos, de Bernardo Figueiredo. A pintura de Milton Dacosta a que se refere a reportagem deve ser Castelo em cinza e vermelho ou Madona, ambas constam no Relatório de Despesas de Murtinho.

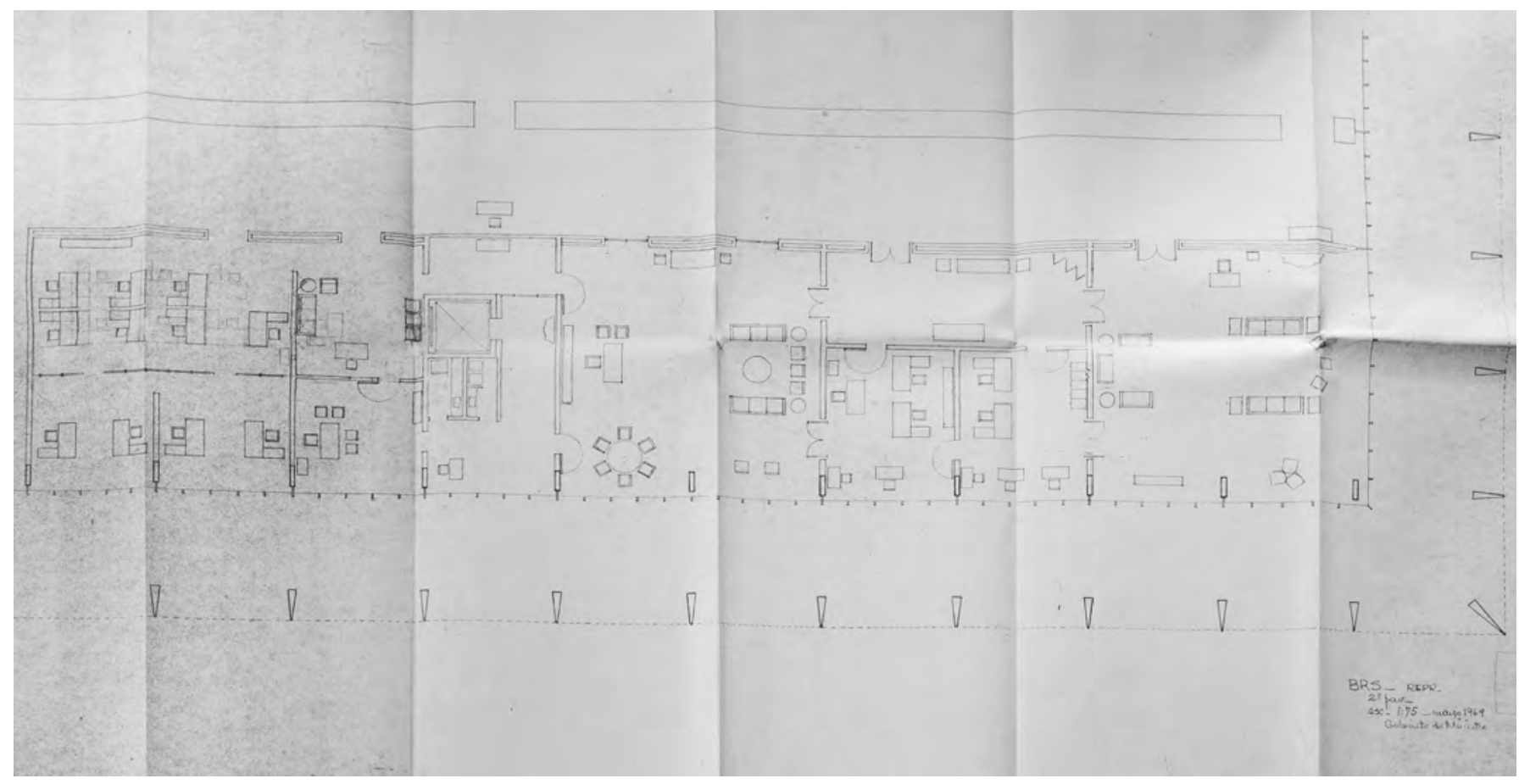

Figura 76: Gabinete do Ministro, 1969. Fonte: SARQ.

55 ALMEIDA, Duílio de. Itamarati, o mais fabuloso palácio moderno do mundo. Jornal Correio Braziliense, Brasília, 07 de junho de 1967, p. 9. 


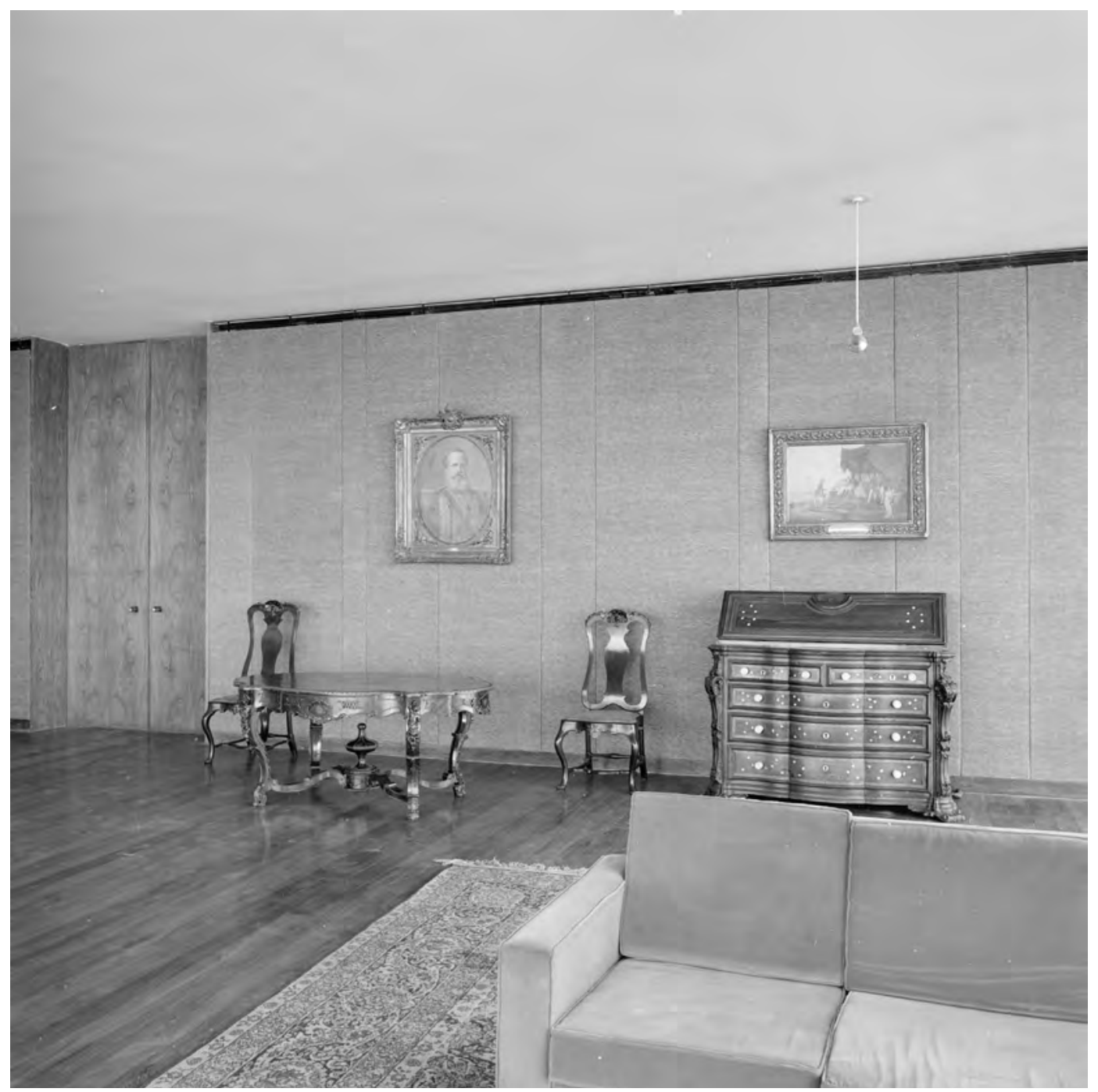

Figura 77: Salão dos Embaixadores, Marcel Gautherot, c.a. 1968. Fonte: Instituto Moreira Salles.

Sobre os gabinetes temos que: "Na última porta, o Salão dos Embaixadores, decorado em estilo clássico com alguns toques de modernismo. Aí estão os retratos de Hipólito José da Costa, D João VI, Pedro II e o quadro do reconhecimento da Independência do Brasil." ${ }^{6}$

Pela descrição e análise das fotografias de Marcel Gautherot e da planta de layout, compreendeu-se que o Salão dos Embaixadores é formado pela pintura histórica Reconhecimento do Império do Brasil e sua independência (entrega de credenciais do Embaixador Charles Stuart), de Leon Tirode e Retrato de D. Pedro II, de Delfim Joaquim Maria Martins da Camara (Figura 77). A pintura que retrata Hipólito José da Costa ${ }^{57}$ foi divulgada

56 ALMEIDA, Duílio de. Itamarati, o mais fabuloso palácio moderno do mundo. Jornal Correio Braziliense, Brasília, 07 de junho de 1967, p. 9.

57 Hipólito José da Costa foi o fundador do periódico Correio Braziliense, que era produzido em Londres, com notícias sobre o Brasil. Correio Braziliense é também o nome dado por Assis Chateaubriand ao jornal fundado em 1960, em Brasília. O período era favorável à nova capital e muito elogioso ao Palácio Itamaraty. 


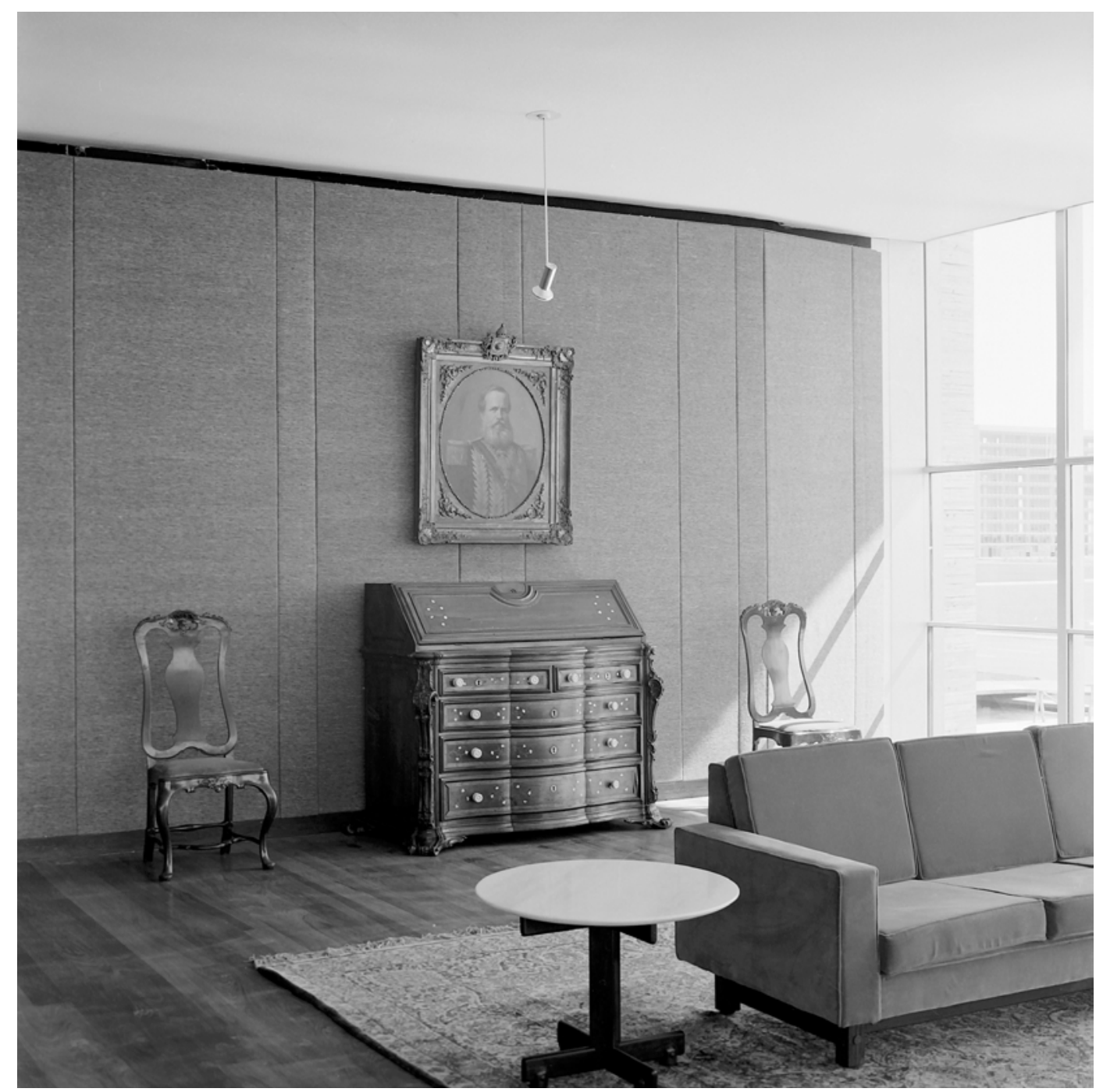

Figura 78: Salão dos Embaixadores, Marcel Gautherot, c.a. 1968. Fonte: Instituto Moreira Salles.

pelo jornal Correio Braziliense que: “Chegará amanhã a Brasília um retrato pintado a óleo, em 1808, em Londres, em que aparece o fundador do Correio Braziliense, Hipólito José da Costa, de pé, com o jornal na mão. Essa obra de arte ficará num dos salões principais do Palácio dos Arcos." 58

Nas fotografias de Marcel Gautherot (Figura 77 e Figura 78), também podemos observar as cadeiras D. João e a cômoda-papeleira D. José I. Além dos móveis modernos, temos a mesa lateral de tampo de mármore, de Sergio Rodrigues e um sofá.

58 CUNHA, Ari. Visto, Lido, Ouvido. Jornal Correio Braziliense, Brasília, 09 de março de 1967, p. 3. 


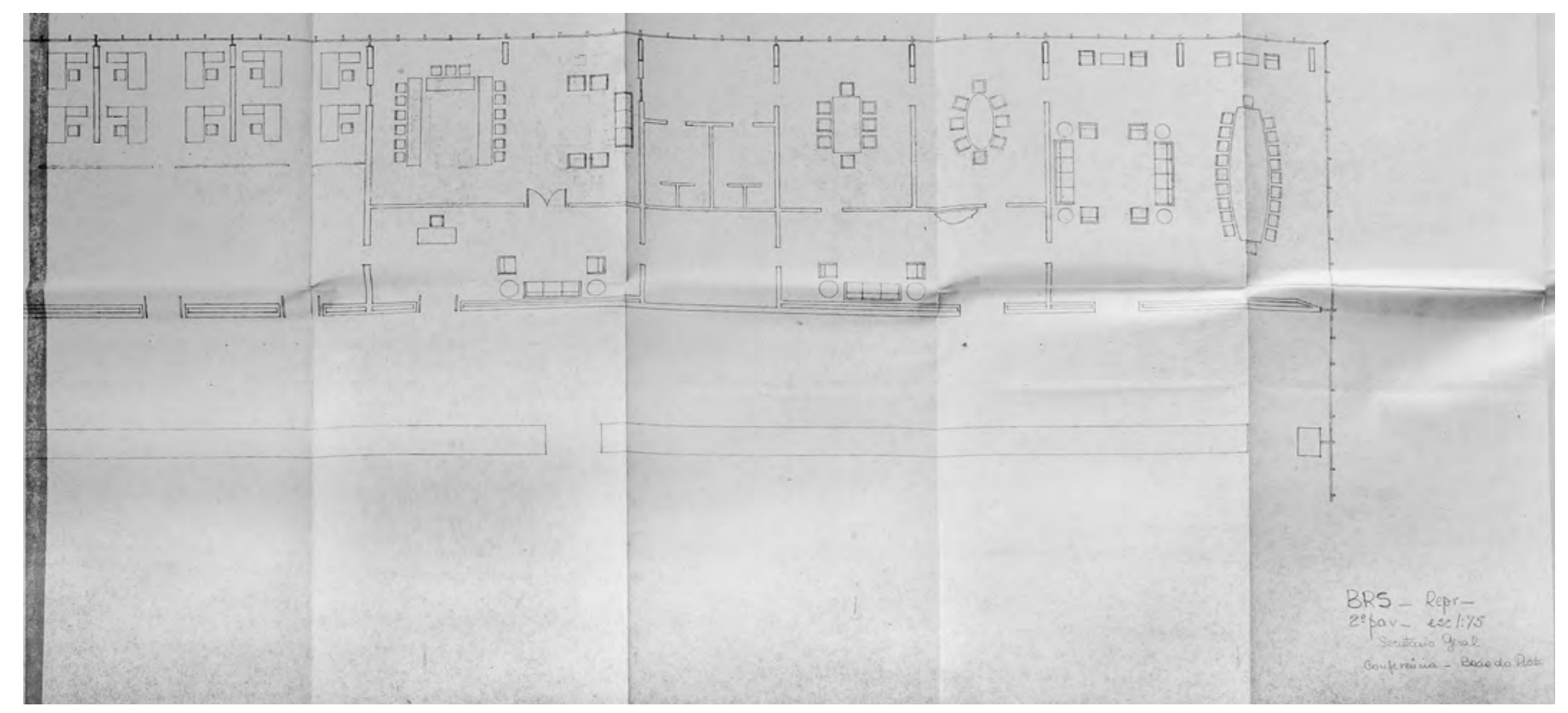

Figura 79: Secretário Geral, 1969. Fonte: SARQ.

Por fim, "de outro lado, a Sala de Reuniões do Conselho da Política Exterior. No imenso salão uma tapeçaria sobre o Mapa de Marini de 1512, primeiro em que consta o nome BRASIL. Ao lado, uma escultura de José Pedrosa: A POMBA.”59 E também os sofás e as poltronas do modelo Embaixador, de couro, desenhadas por Bernardo Figueiredo, além da escultura de Nossa Senhora das Mercês, do século XVIII (Figura 80). Sobre a tapeçaria, Murtinho conta que:

E temos por exemplo, algo muito curioso, que é o mapa de Marini, o primeiro onde consta o nome Brasil. Esse mapa, que literalmente é a peça chave da nossa história. E esse mapa está ainda guardado no Rio de Janeiro, na mapoteca. Nós fizemos uma tapeçaria, que hoje está no gabinete do ministro, que Madelaine Colaço se inspirou nesse mapa, e é uma das coisas curiosas porque as pessoas se espantam. É um mapa, que está centrado sobre Jerusalém, então a posição é que se, que ocupa a América Latina e o Brasil, em conseqüência é completamente diferente daquela que você está acostumado a ver. (MURTINHO, 1990, p. 16)

59 ALMEIDA, Duílio de. O que ver no Itamarati, Jornal Correio Braziliense, Brasília, 19 de abril de 1969, Caderno 2, p. 13. 
4. OS ESPAÇOS PALACIANOS / 145

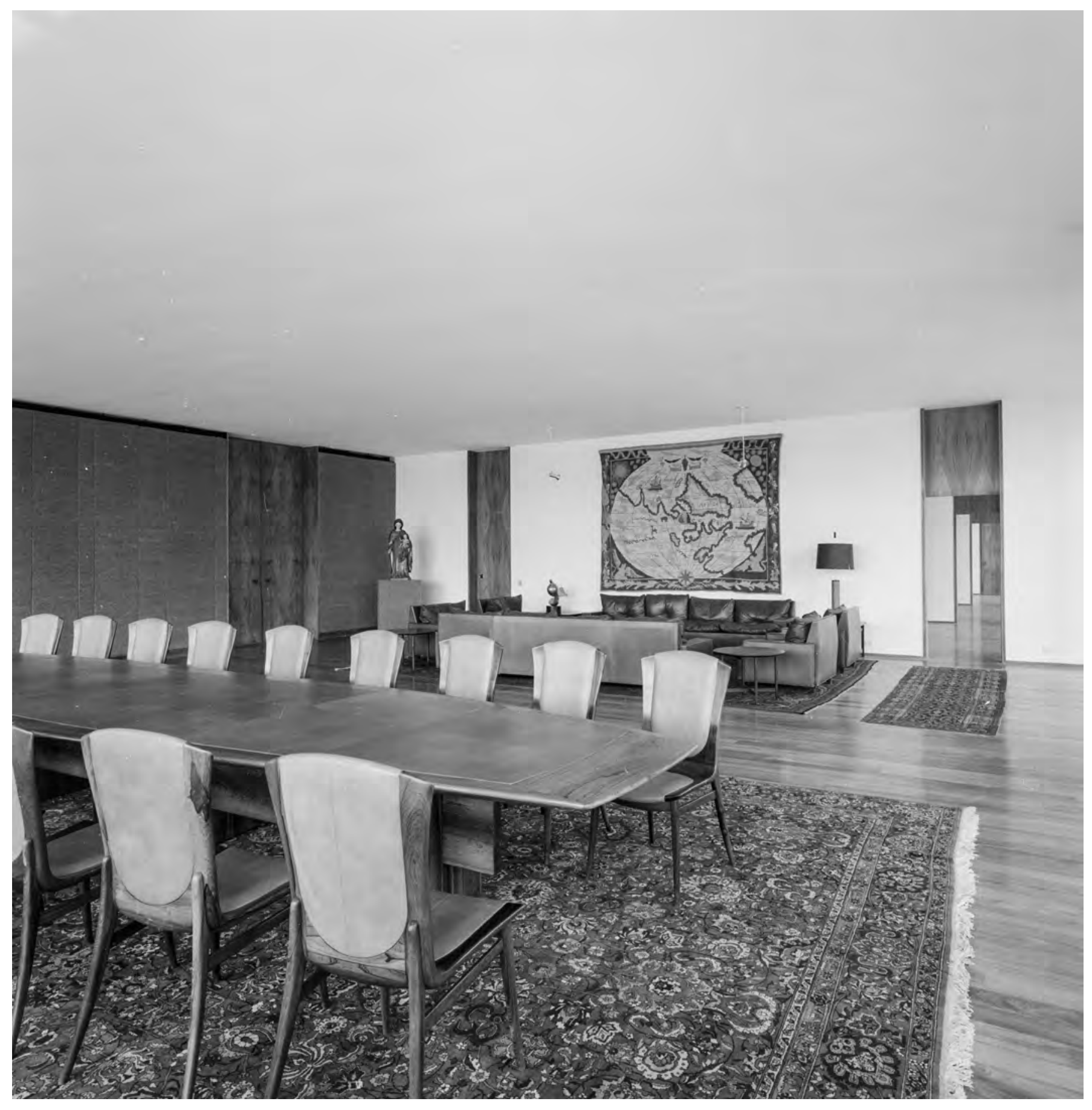

Figura 80: Sala de Reuniões do Conselho da Política Exterior, Marcel Gautherot, c.a. 1968. Fonte: Instituto Moreira Salles. 


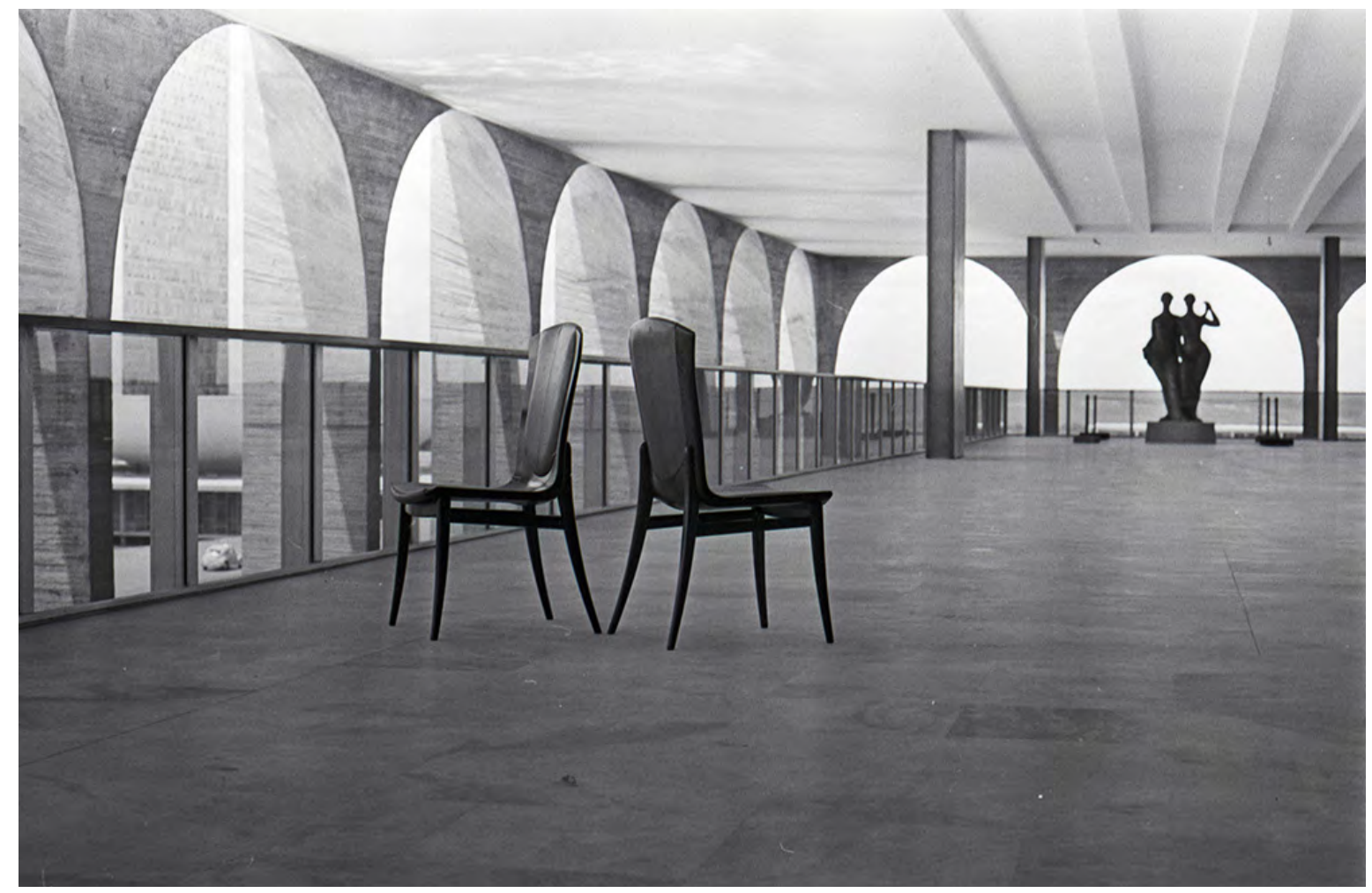

Figura 81: "Cadeira dos Arcos”, Bernardo Figueiredo, datação não identificada. Fonte: Acervo Bernardo Figueiredo.

Bernardo Figueiredo projetou a mesa de reunião de 7 metros, em jacarandá e couro, e 24 cadeiras também em jacarandá e couro, nomeadas como Cadeira dos Arcos (Figura 80). Todos os mobiliários de Bernardo Figueiredo eram produzidos artesanalmente. A nomenclatura e o desenho do espaldar fazem referência aos arcos do palácio. Em texto posterior sobre a cadeira, Bernardo Figueiredo conta que: "Seu destino inicial era para o Grande Salão de Recepção e Banquetes." "6o Essa afirmação explica o desenho do mobiliário que dialoga com a arquitetura do palácio (Figura 81).

60 O texto está em rascunhos de Bernardo Figueiredo que pertencem ao Acervo Bernardo Figueiredo. 


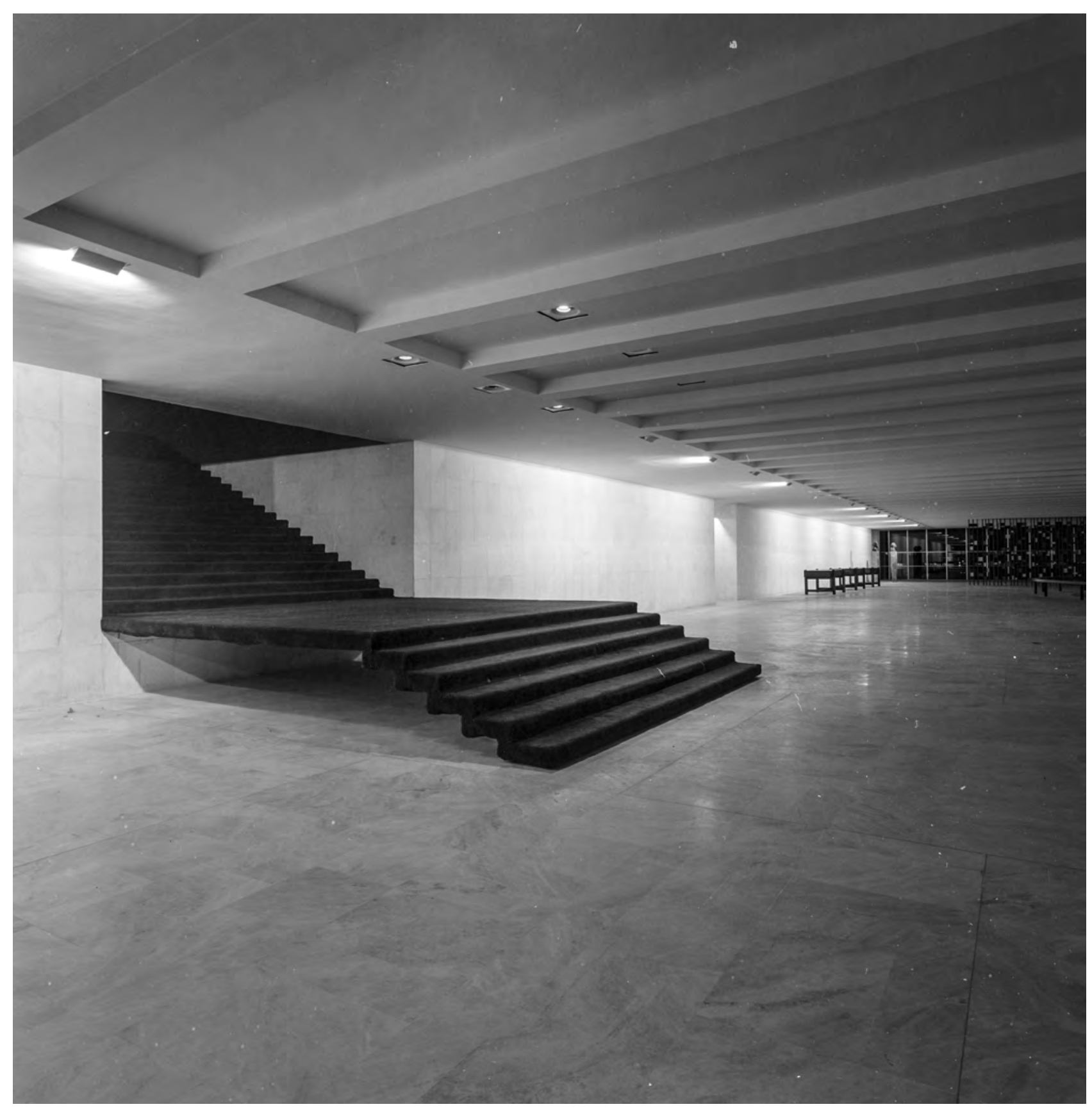

Figura 82: Escada de acesso ao Terceiro Pavimento, Marcel Gautherot, c.a. 1968. Fonte: Instituto Moreira Salles.

O Segundo Pavimento é composto pelas salas intermediárias de recepção - transição entre o hall principal da entrada e o terceiro pavimento, com as áreas destinada aos banquetes e festas - e pelos gabinetes. As salas destinadas ao trabalho de escritório são marcadas por móveis funcionais desenhados pelos designers brasileiros Sergio Rodrigues e Bernardo Figueiredo. São peças mais pesadas, retilíneas, com cores sóbrias, em que o verde musgo domina. Há também os móveis históricos, tapeçarias, pinturas e esculturas na ambientação do pavimento. Algumas das peças contam uma narrativa de história sobre o país, como a tapeçaria do Mapa de Marini e $O$ Grito do Ipiranga que colocam o Brasil como protagonista. 


\subsection{TERCEIRO PAVIMENTO}

CORTE TRANSVERSAL: INDICAÇÃO ESQUEMÁTICA DO PAVIMENTO 
4. OS ESPAÇOS PALACIANOS / 149

\section{"A criação não é uma compreensão, é um novo mistério." 61}

Clarice Lispector

61 LISPECTOR, Clarice. "Nos primeiros começos de Brasília”. Jornal do Brasil, Rio de Janeiro, 20 de junho de 1970. 


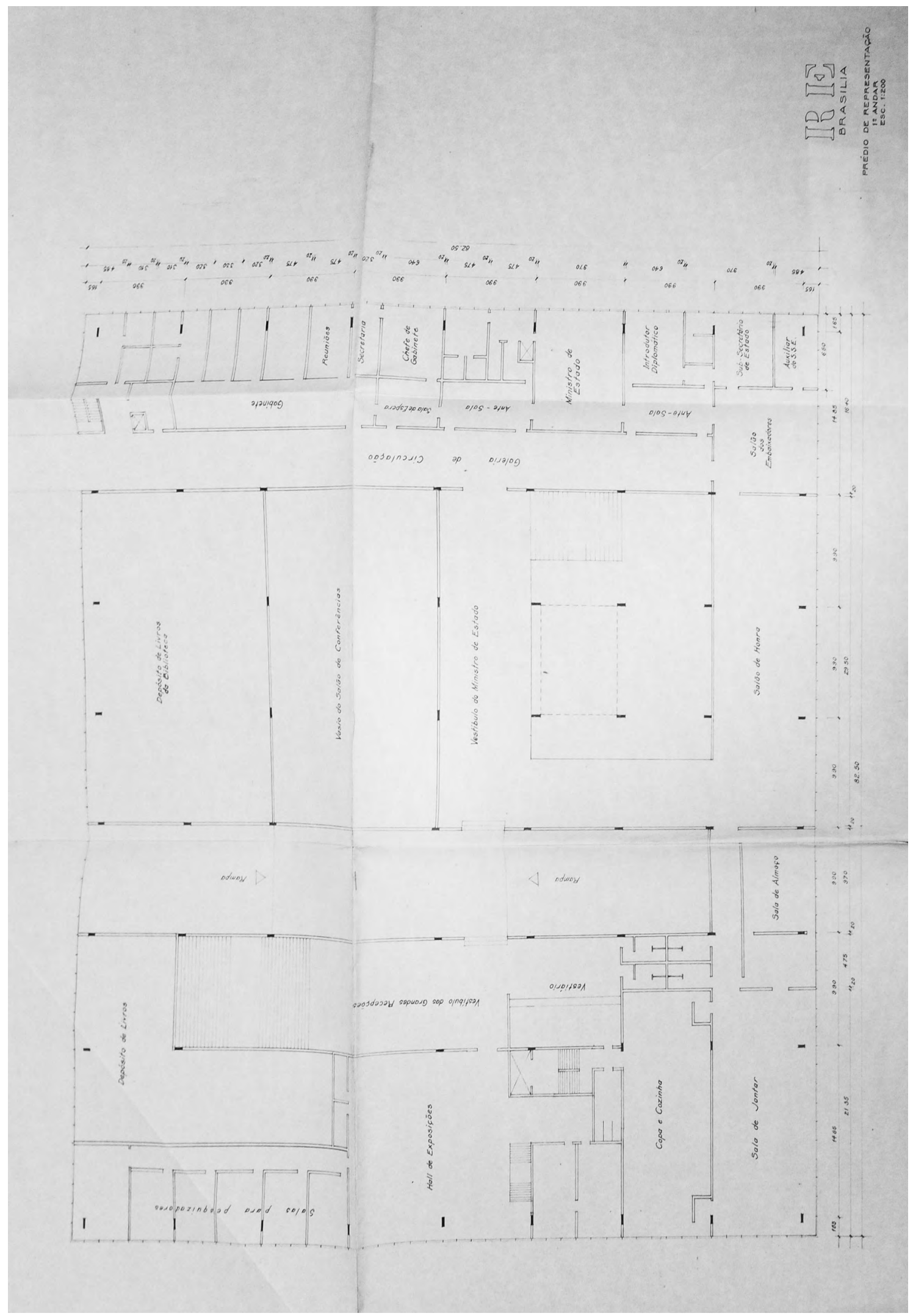

Figura 83: Prédio de Representação - $2^{\circ}$ Andar, datação não identificada. Fonte: SARQ. 
Dentre todas as soluções do projeto, a do Terceiro Pavimento é a primeira a encontrar a forma final. Nos projetos iniciais, divulgado pela matéria "Palácio Rio Branco, Brasília", de Jayme Maurício, na Revista Habitat n ${ }^{0}$ 52, em janeiro de 1959, o desenho parte da necessidade de um jardim para as atividades sociais, mas "havia um obstáculo: todos os jardins dos edifícios públicos são totalmente abertos e era preciso um jardim fechado para as festas do governo. Funcionou novamente a imaginação de Niemeyer: jardim suspenso, no terraço." De modo que "Na laje do $2^{\circ}$ andar, que mede $87,5 \mathrm{~m}$ x 87,5 m, acham-se localizados os grandes salões e o terraço com jardins, espelhos d'água e uma palco." (MAURÍCIO, 1959)

No projeto executado, a ideia central do pavimento continuou a mesma: lugar destinado às recepções, com salão de baile e de banquetes e o jardim suspenso com vista para a Praça dos Três Poderes.

Na planta mostrada na Figura 83, sem datação, já se vê a delimitação dos espaços, embora algumas salas tenham mudado de função, a separação dos ambientes continuou a mesma. O Salão de Baile, o jardim suspenso, a cozinha e o salão de banquetes permaneceram nos mesmos lugares. A copa do cerimonial e o anexo do salão de banquetes tornaram-se duas salas de banquetes menores. A copa, saleta e salão, com vistas ao Eixo Monumental, foram retiradas no projeto executado e tornaram-se o Pequeno Salão.

No projeto de 1965, a divisão dos ambientes já está definida, com exceção da parede que separava o hall do salão de banquetes e da entrada dos banheiros sociais que era delimitada por paredes retilíneas (Figura 84). Em 1967, a entrada do banheiro ganha as paredes inclinadas em planta e revestidas de mármore que permitem o acesso, sem que essa entrada seja uma ruptura no caminhar pelo ambiente (Figura 85 ). Tal solução possibilita uma transição lenta entre os ambientes, entre aberturas e fechamentos. 


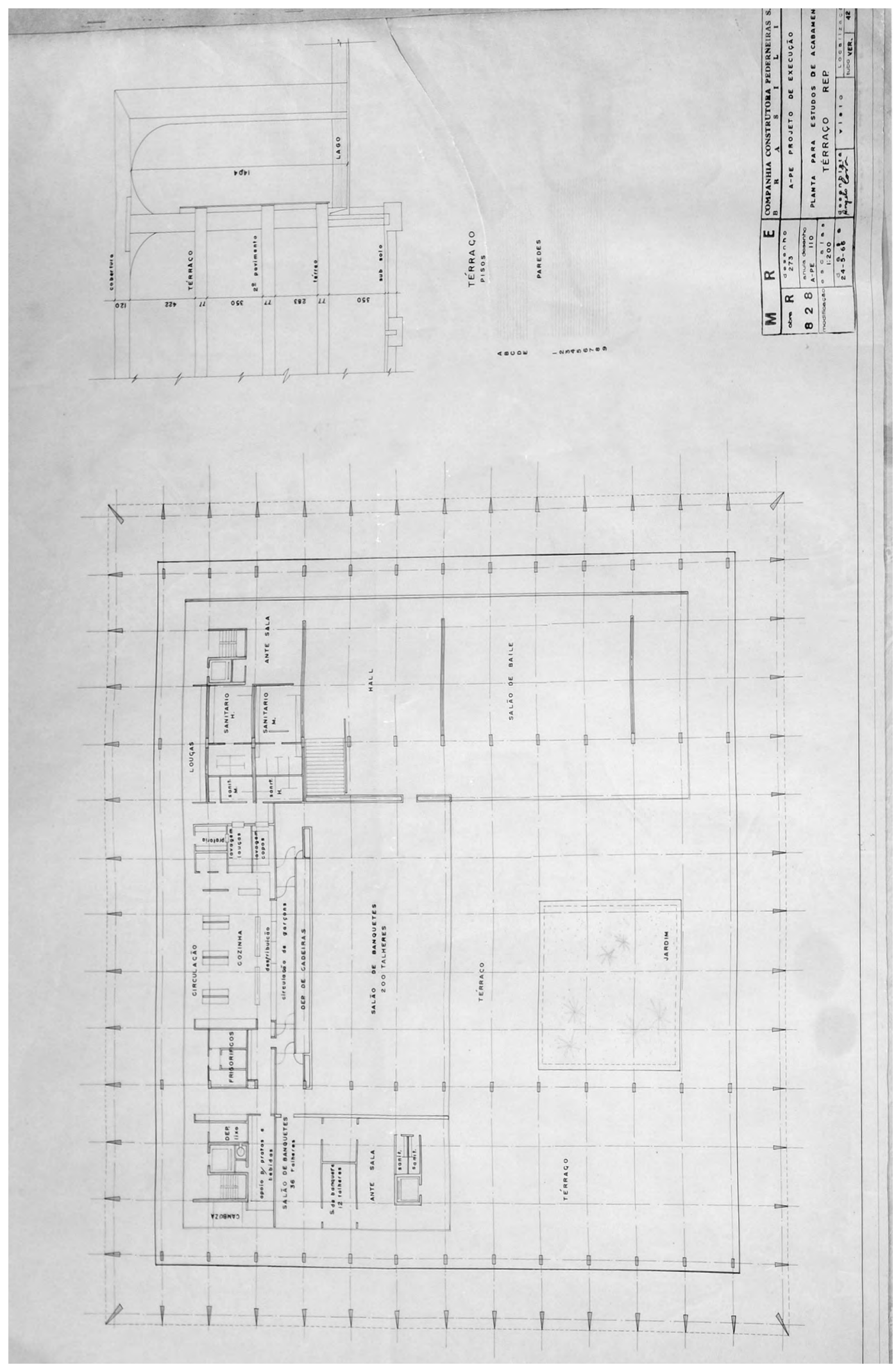

Figura 84: Planta para estudo de acabamento, 1966. Fonte: SARQ. 
4. OS ESPAÇOS PALACIANOS / 153

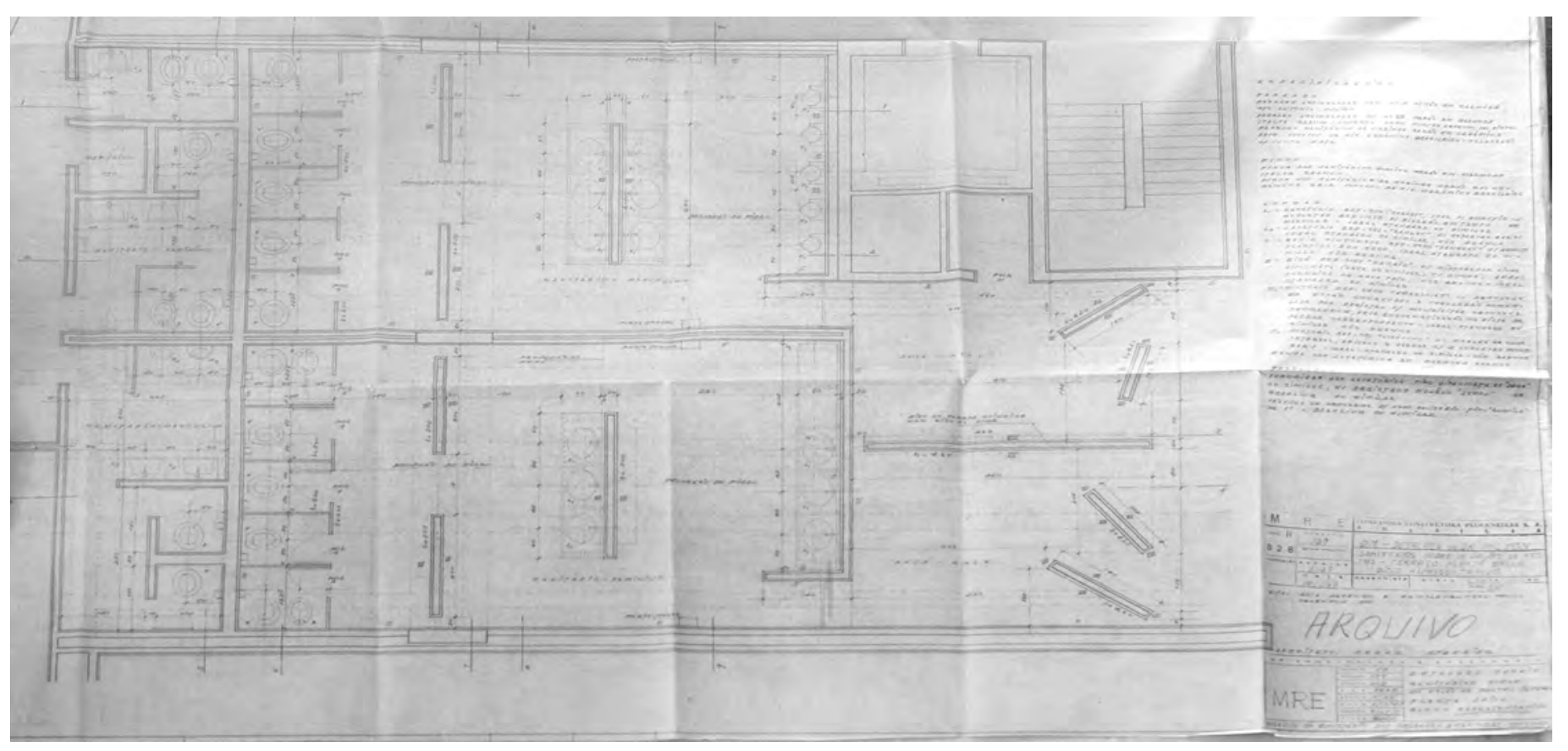

Figura 85: Sanitário do Salão de Festas, 1967. Fonte: SARQ. 


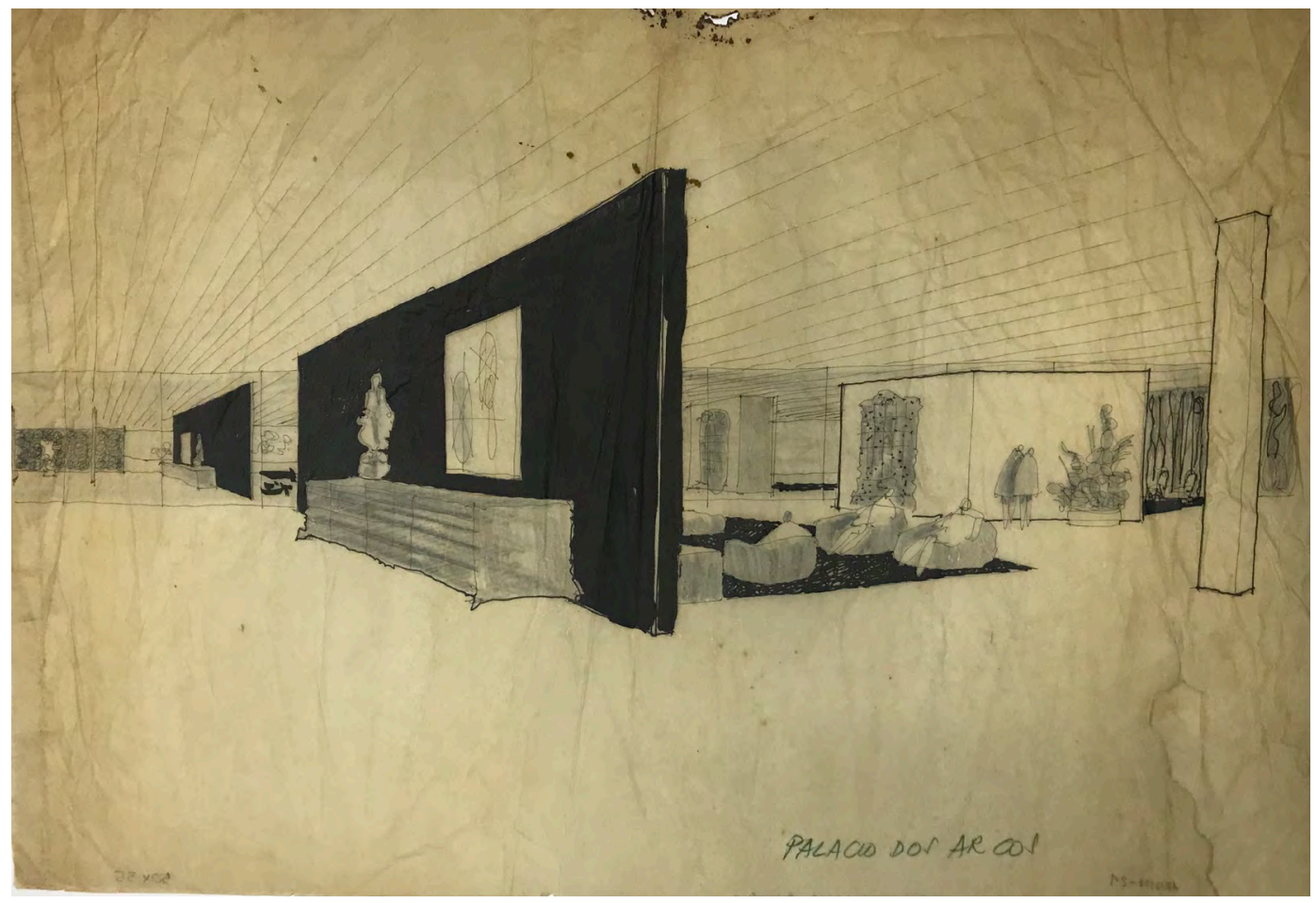

Figura 86: Estudo para o projeto de interiores do Palácio dos Arcos, Sergio Rodrigues, datação não identificada. Fonte: Instituto Sergio Rodrigues.

Sergio Rodrigues fez uma perspectiva do que seria parte dos ambientes do Terceiro Pavimento próximos à escada de acesso (Figura 86). Em seu desenho, já vemos o espelho que reflete as salas, um arcaz e uma escultura, ao lado esquerdo do desenho. Ao centro, há o Salão de Baile com poltronas generosas - quase pufes - para que os convidados se sentissem à vontade.

Embora sem data, a planta (Figura 87) já está com o layout executado, com o vestíbulo, o Salão de Baile, o Pequeno Salão, a Sala de Banquetes, duas salas menores destinadas às salas de almoço, as chamadas Sala Bahia e Sala Rio de Janeiro, além do terraço com o jardim suspenso.

Logo ao subir a escada, temos o espelho de 70 metros de comprimento e 4,2 metros de altura e o vestíbulo que faz o acesso ao pavimento. Neste ambiente:

O espelho negro é a primeira surpresa. No teto, a revoada de pássaros, de Pedro Correia de Araújo, toda executada com ferro e cristais de rocha. É a sua primeira foto do salão superior. Um quadro de Manubi Mabi (sic), denominado JURAMENTO, chama a atenção. Você se demora tentando compreendê-lo. Ao seu lado um arcaz de Pernambuco [do século XVII]. Olha para Nossa Senhora das Mercês, um trabalho executado em madeira com pintura de um século depois. $^{62}$

62 ALMEIDA, Duílio de. O que ver no Itamarati, Jornal Correio Braziliense, Brasília, 19 de abril de 1969, Caderno 2, p. 13. 
4. OS ESPAÇOS PALACIANOS / 155

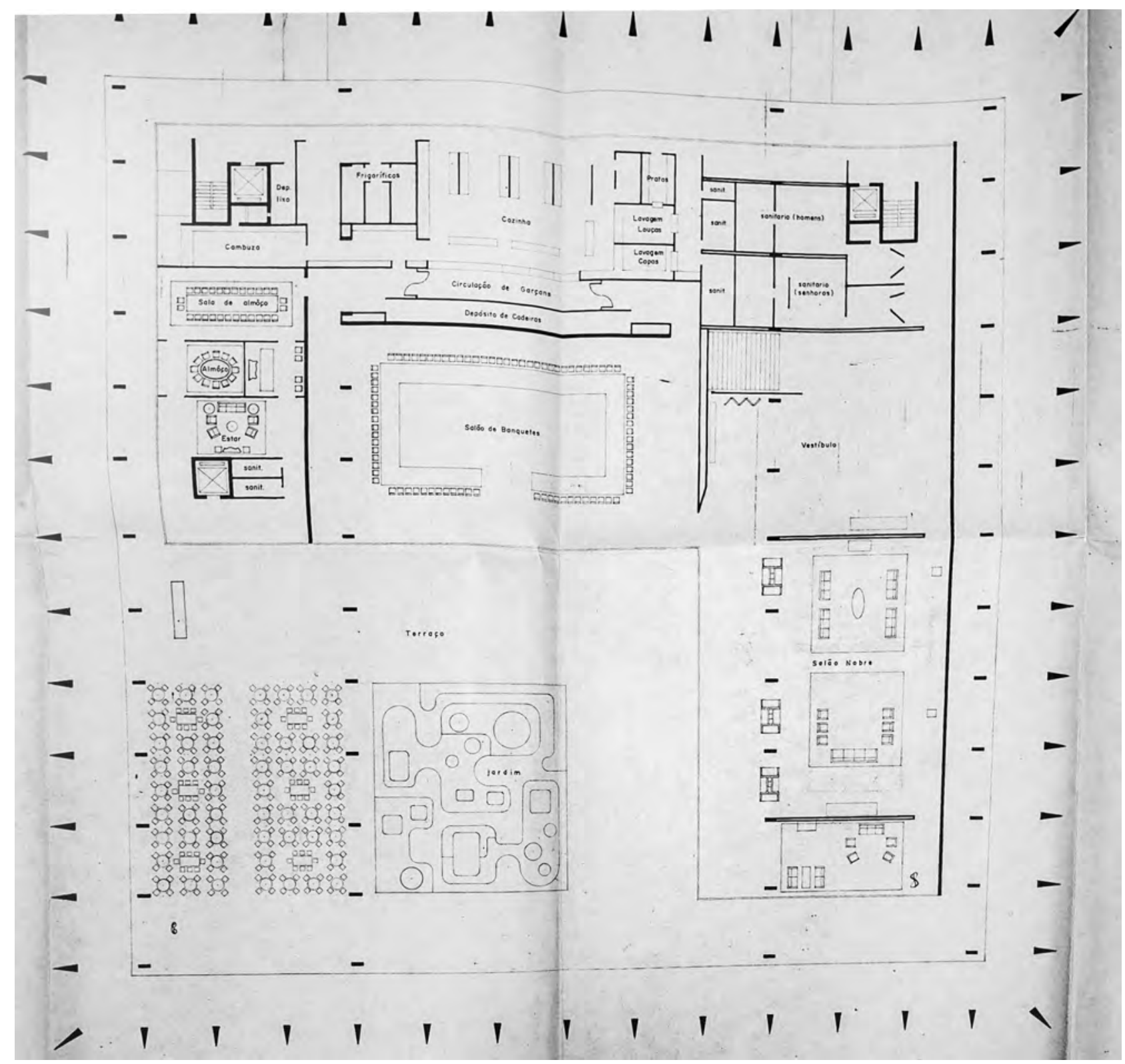

Figura 87: Layout Terceiro Pavimento, datação não identificada. Fonte: SARQ.

Defronte ao espelho, há o banco de sacristia do século XVIII, proveniente da Bahia, que consta no Relatório de Despesas de Murtinho, como também as demais peças já citadas (Figura 89). 


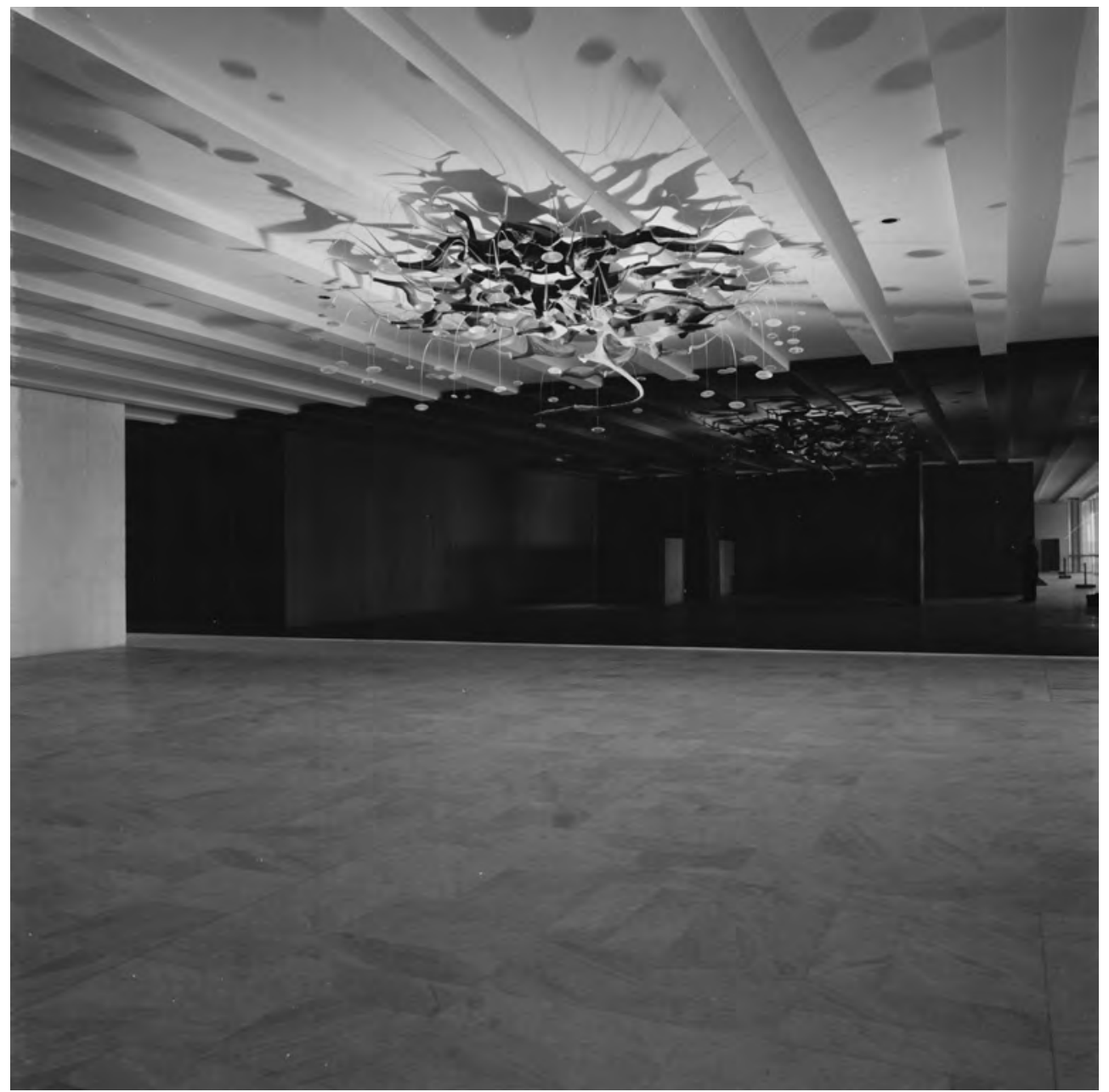

Figura 88: “Revoada dos pássaros", Pedro Correia de Araújo, Marcel Gautherot, c.a. 1968. Fonte: Instituto Moreira Salles.

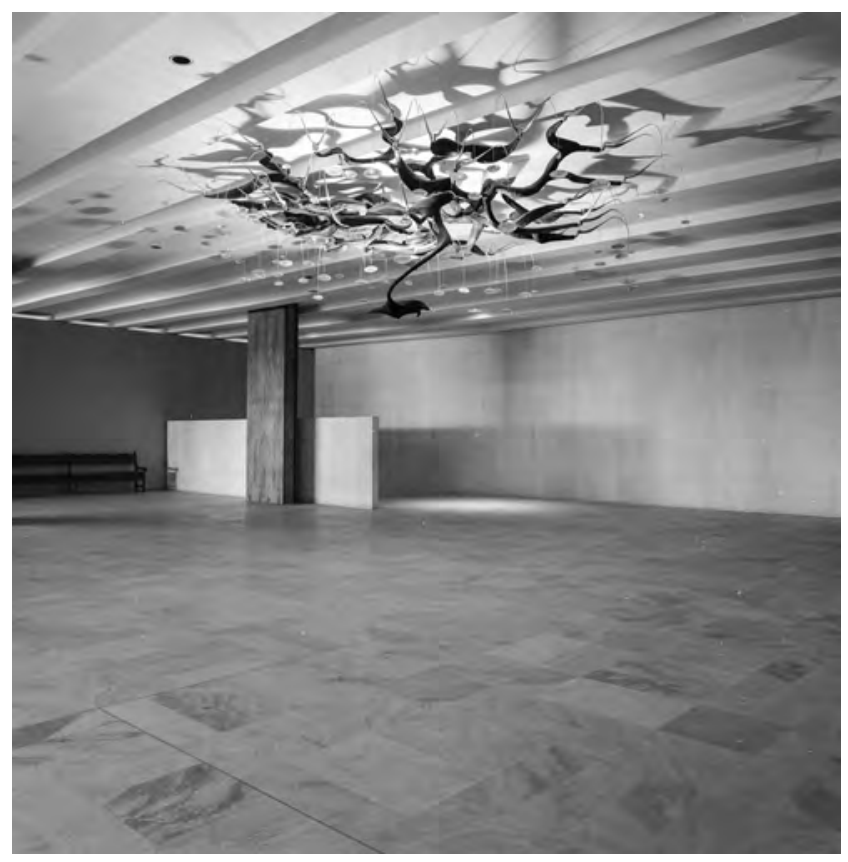

Figura 89:"Revoada dos pássaros", Pedro Correia de Araújo, Marcel Gautherot, c.a. 1968. Fonte: Instituto Moreira Salles. 
Sobre o lustre Revoada de Pássaros, em carta enviada para Pietro Maria Bardi, Pedro Araújo Correia de Araújo ${ }^{63}$ conta que:

Esse lustre foi todo feito em vergalhões de ferro de 1/8 por $1 / 2$ soldados um ao lado do outro por solda de oxigênio formando portanto os elementos ôcos de onde partem hastes de metal fundido prateado que seguram os cristaes lapidados. São mais ou menos 100 cristais, pesando o lustre por volta de $1300 \mathrm{~kg}$. Sendo $750 \mathrm{~kg}$ de ferro. Sendo aproximadamente $5 \mathrm{~m}$ de diâmetro por $1,7 \mathrm{~m}$ de altura. Tem uma lâmpada de mercúrio com $1500 \mathrm{w}$ na haste mais baixa e mais uns 1000 w em lâmpadas comuns nos ocos da parte junto ao teto para tirar a sombra do mesmo.

Levei quase sete meses trabalhando na parte da solda e furação dos cristaes.

A ideia da forma me ocorreu quando voltava de Brasília depois de 3 dias em completa [forma] criadora, pois era a $1^{\text {a }}$ vez que ia a Brasília e o tamanho da responsabilidade + os problemas; pouco pé direito 4,20 m e a estrutura aparente no teto duas vigas de sustentação que iriam [cortar/custar] muito na fusão[fisão] final.

Bem, aproveitando uma carona de carro para poder conhecer o cerrado do planalto que sabia ser maravilhoso deixei o emb. Wladimir Murtinho voltar só de avião. Como socius de Brasília depois do almoço anoitecemos no cerrado.

Já eu atraz encostado, olhando o céu passar do azul, amarelo claro, e depois em vermelho sangue e de repente, uma verdadeira revoada de cacervous pequenas corujas e esses pássaros negros contra o céu escuro e as estrelas que iam surgindo me deram a solução.

Wladimir Murtinho aceitou a ideia sem nunca me aconselhar nem opinar, dando, portanto, toda liberdade na execução.

Este vestíbulo ou pequeno hall é um momento de pausa (Figura 89). Podese ver os demais ambientes pelo reflexo do espelho. Há o lustre que altera a percepção do pé direito do ambiente, mas que dá a sensação de massas de cores espalhadas, sensação que também nos dá a pintura Juramento de Manabu Mabe. O banco da sacristia nos remete a um lugar de espera para os demais lugares. 


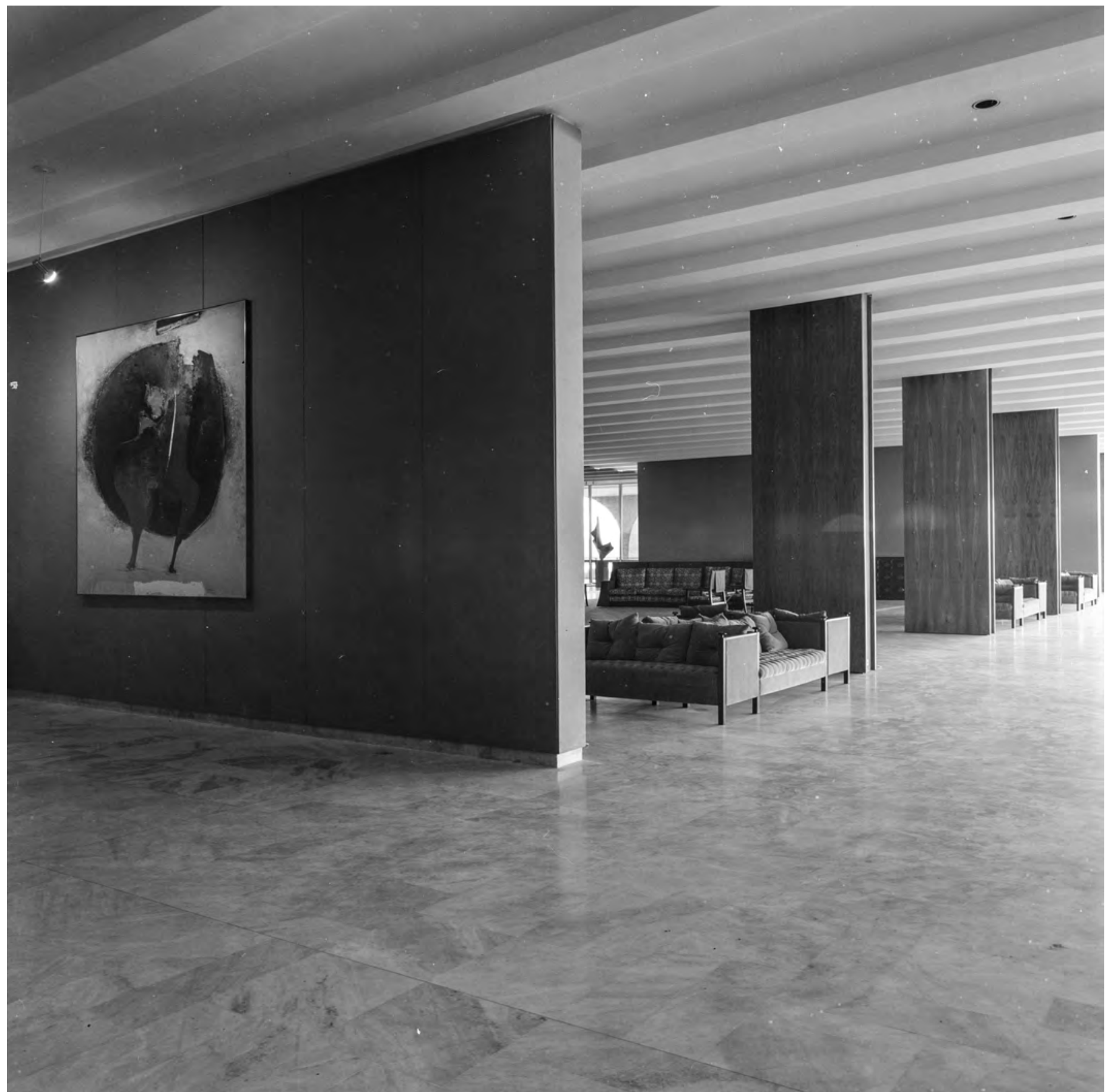

Figura 90: "Juramento", Manabu Mabe, Marcel Gautherot, c.a. 1968. Fonte: Instituto Moreira Salles.

A divisória em que está a pintura Juramento, de Manabu Mabe, separa o vestíbulo do Salão de Baile que, em projetos de 1963, era chamado como Salão de Festas; em outros de 1965 e 1966, como Salão de Baile e também como Salão Nobre. Em um projeto, sem datação, e no Relatório de Despesas de Wladimir Murtinho é nomeado como de Salão de Honras (Figura 90). Neste ambiente: 
(...) se defronta com salas amplas, onde em dias de recepções, os convidados dialogam, as autoridades aproveitam e trocam pontos de vistas sobre a situação político-econômica, ou simplesmente se referem aos problemas que estão em suas pastas. Você entra no imenso salão de festas. A escultura de Maria Martins, "A mulher e a sua sombra" [doada pela artista], postada ao lado do espelho negro, lhe interessa. Você admira o belíssimo arcaz de Paracatu, comprado pelo Ministro Osvaldo Aranha, em 1942, do século XVIII e doado ao Itamarati pela Embaixada do Brasil em Washington. ${ }^{64}$

O salão também conta com duas esculturas de anjos proveniente da Igreja de São Pedro dos Clérigos, no Rio de Janeiro (Figura 91). É um salão com duas áreas delimitadas por tapetes com sofás médios revestidos em seda verde, mesas pequenas com tampo em cristal ou mármore, além dos sofás modulados em veludo amarelo, do conjunto de um sofá e seis poltronas, em jacarandá, revestidos por shantung azul e verde, com bordados feitos à mão. Todos foram desenhados por Bernardo Figueiredo, com colaboração de Jorge Hue, sendo que o último foi responsável pela ambientação do salão, conforme aponta o Relatório de Despesas de Wladimir Murtinho. Todas as peças foram encomendas para este ambiente (Figura 91, Figura 92 e Figura 93). Mais do que um mobiliário palaciano de escritório - como nos gabinetes do Segundo Pavimento - aqui era preciso desenhar móveis palacianos para recepções, o que permitiu experimentos no desenho para Bernardo Figueiredo. A necessidade de mobiliar este ambiente produziu reflexões acerca do que seria um móvel palaciano e moderno. Para Bernardo Figueiredo, um móvel palaciano era grande. Mas não só.

Bernardo Figueiredo escreveu sobre o sofá conversadeira que está no palácio:

No Palácio dos Arcos em Brasília cheguei a criar quatro conjuntos formados por quatros sofás, uns de costas para os outros. Estes conjuntos devido às grandes dimensões do Salão de Recepções, situam-se na cobertura do palácio. A versatilidade destes conjuntos substitui os conhecidos puffs. E passaram a ser as verdadeiras conversadeiras durante as recepções. ${ }^{65}$

64 ALMEIDA, Duílio de. O que ver no Itamarati. Jornal Correio Braziliense, Brasília, 19 de abril de 1969, Caderno 2, p. 13. 


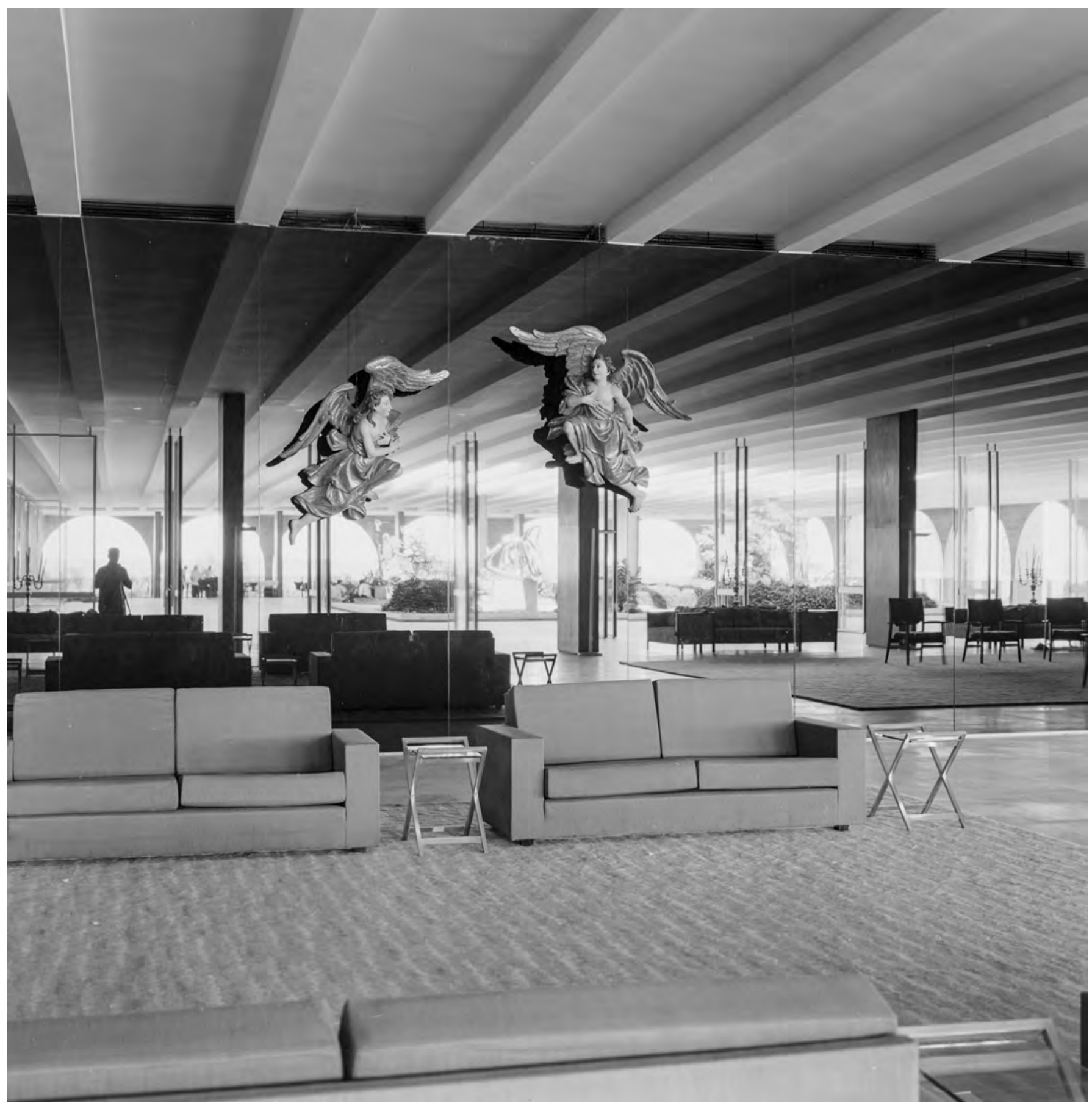

Figura 91: “Anjos”, autoria desconhecida, Marcel Gautherot, c.a. 1968. Fonte: Instituto Moreira Salles. 
4. OS ESPAÇOS PALACIANOS / 161

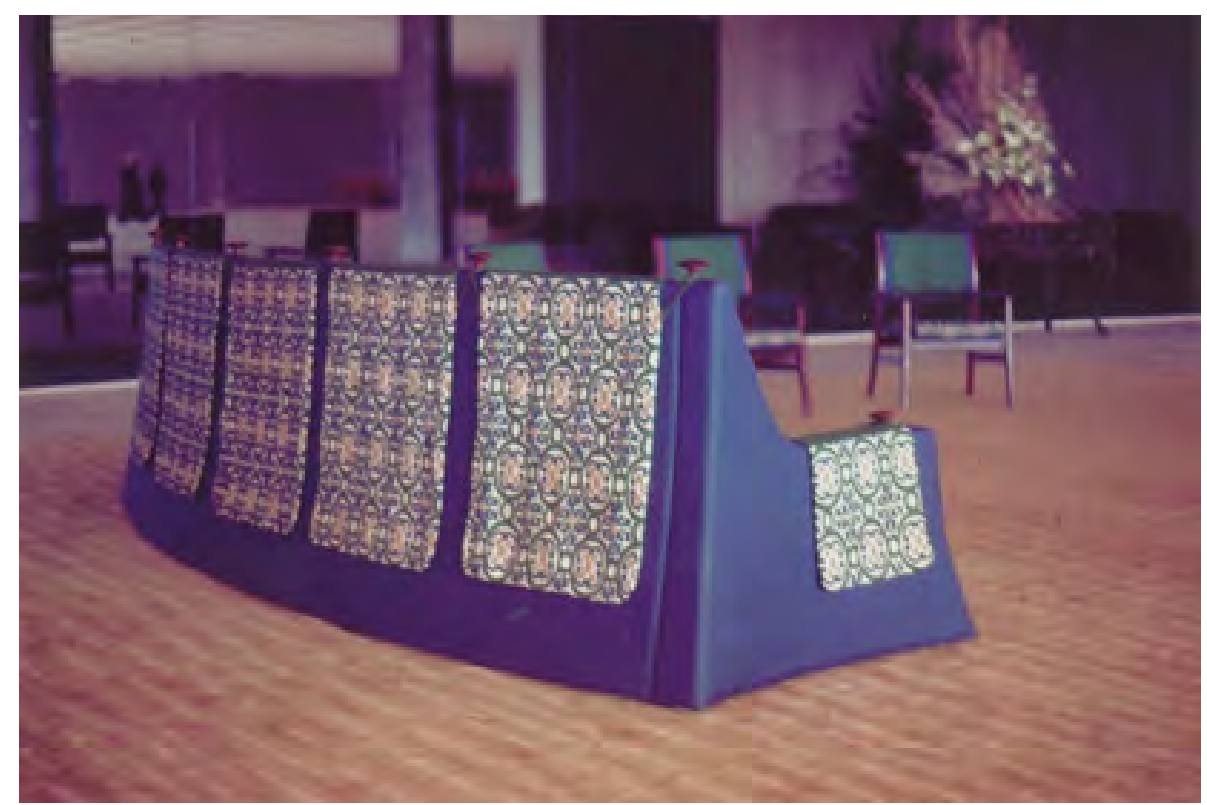

Figura 92: "Sofá Rei", Bernardo Figueiredo, datação não identificada. Fonte: Acervo Bernardo Figueiredo.

Assim, como se pode ver pela descrição de Bernardo Figueiredo e pelo desenho de Sergio Rodrigues (Figura 86), era desejado também certo despojamento neste ambiente de um palácio com o cerimonial tão rigoroso.

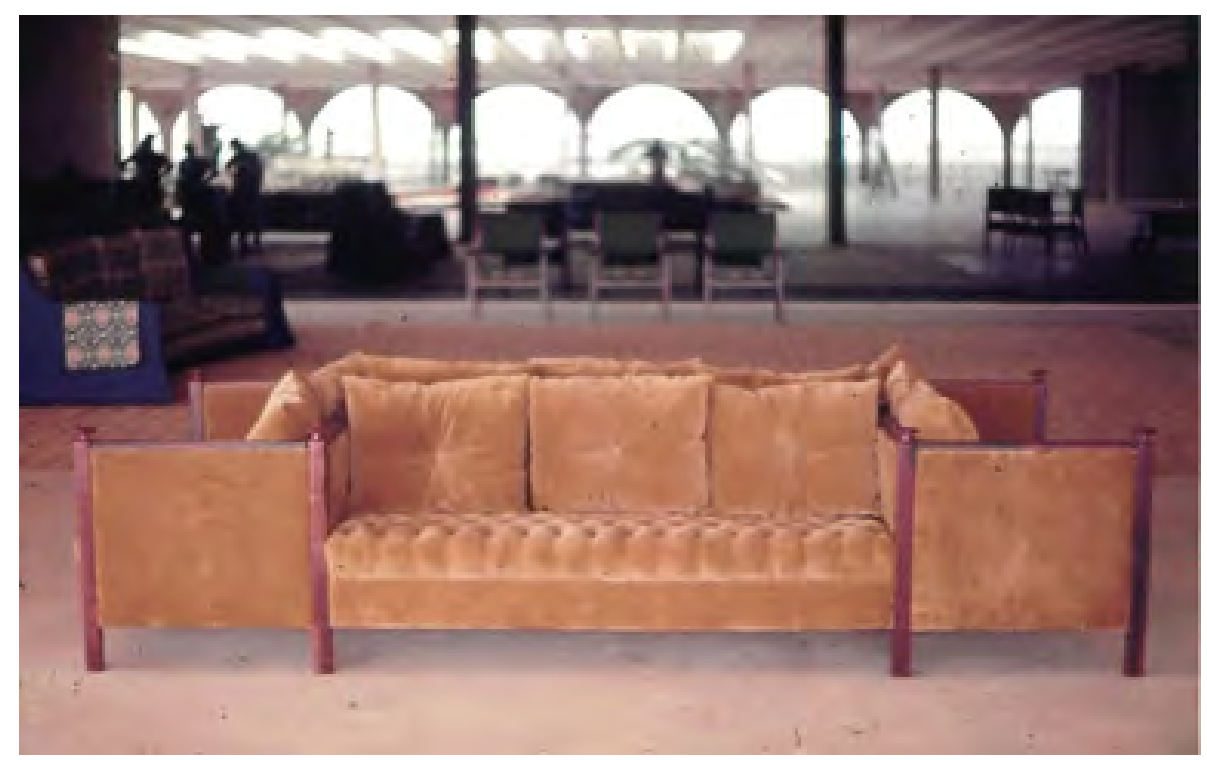

Figura 93: Conversadeira, Bernardo Figueiredo, datação não identificada. Fonte: Acervo Bernardo Figueiredo. 


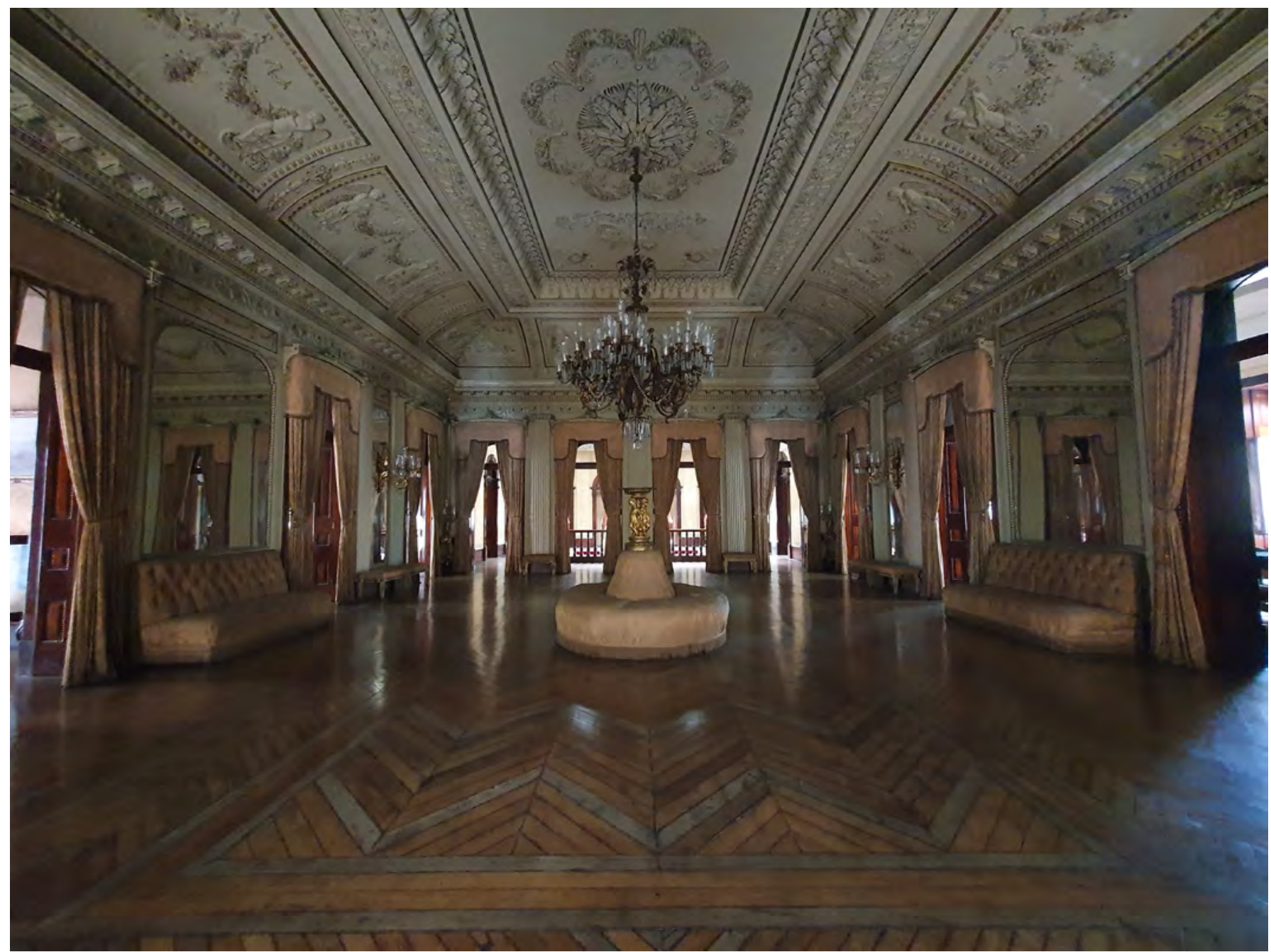

Figura 94: Salão de Baile, Palácio Itamaraty, Rio de Janeiro. Fonte: Karen Matsuda, 2020.

O mobiliário era austero e passava uma imagem de nobreza. Além do mais, a inclinação da parte posterior do Sofá Rei (Figura 92) permite que as pessoas conversem sentadas no sofá sem que alguém, vindo de trás, escute a conversa. Era um ambiente de estar com mobiliário pensado para o cerimonial diplomático.

O Salão de Baile também existe no Palácio Itamaraty do Rio de Janeiro. Entende-se que a solução rápida deste pavimento ocorreu pela referência ao antigo palácio. Neste Salão de Baile (Figura 94), há sofás que lembram as conversadeiras desenhadas por Bernardo Figueiredo, pelo uso das cores e dos materiais. Mas também pela possibilidade de ser ocupado em todos os lados (Figura 93). Esta mesma solução ocorre na conversadeira que ocupa o centro do Salão de Baile do palácio carioca. Como nos demais ambientes, as peças de mobiliário ocupam, sobretudo, o centro das salas. $\mathrm{Na}$ antiga sede, eram colocadas próximo à parede. 

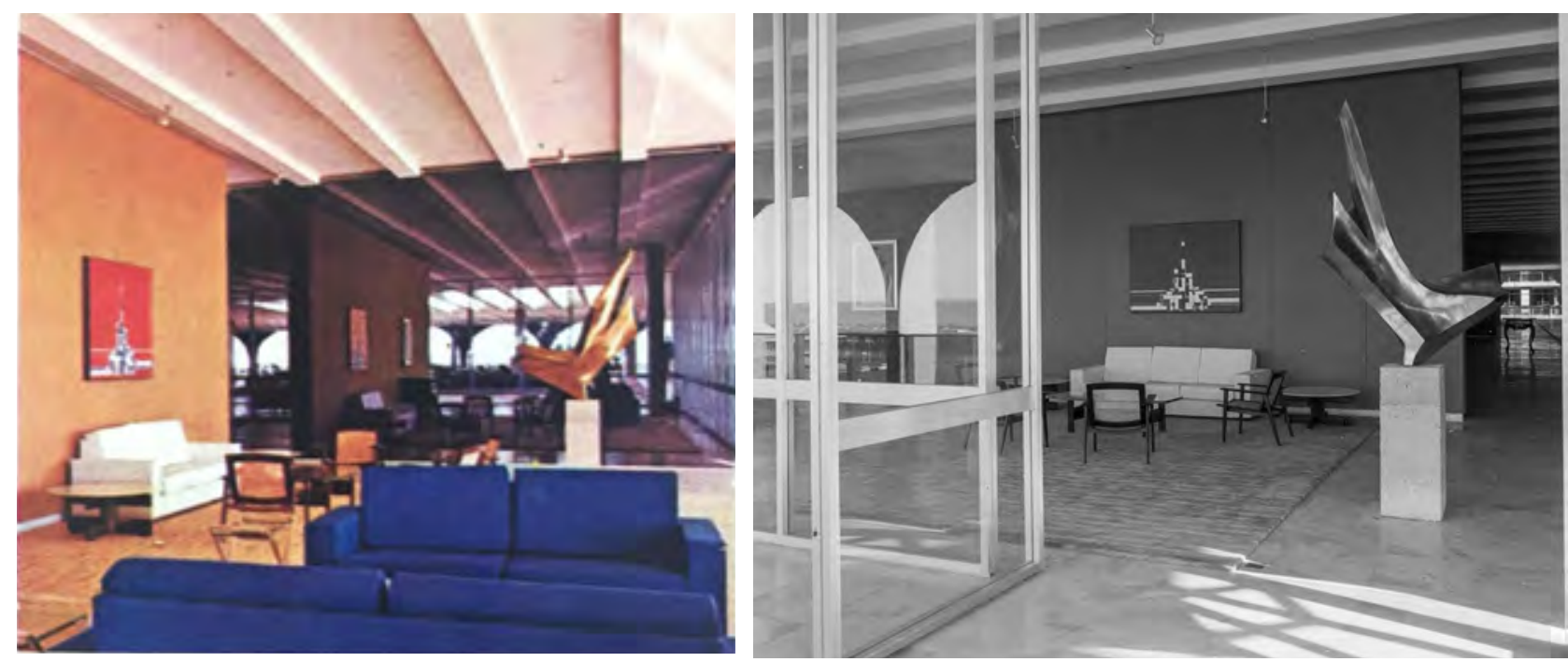

Figura 95: Pequeno Salão, sem autoria, datação não identificada. Fonte: Connaissance des Arts, 1968.

Figura 96: Pequeno Salão, Marcel Gautherot, c.a. 1968. Fonte: Instituto Moreira Salles.

A sala voltada para o Eixo Monumental, chama-se Pequeno Salão (Figura 95 e Figura 96), também é uma sala de estar, composta por dois sofás revestidos em seda azul e um de seda branca, oito poltronas de jacarandá e palhinha, a Poltrona Rio, e quatro pequenas mesas. Todas as peças foram desenhadas por Bernardo Figueiredo. Há também uma cômoda classificada como móvel antigo, duas obras de Milton Dacosta ${ }^{66}$, uma nomeada como Figura, a outra provavelmente é Castelo em cinza e vermelho. Próximo ao espelho, temos a escultura Pássaro de Fogo, de Luíza Muller, que foi uma doação da artista. As esculturas, neste pavimento, encontravam-se próximas ao espelho, pois o mesmo foi dito sobre a escultura $A$ mulher e a sua sombra, de Maria Martins ${ }^{67}$.

O setor destinado aos banquetes é dividido em três salas (Figura 87). O Salão de Banquetes (Figura 102) para 200 pessoas é formado por 15 mesas conjugáveis e 120 cadeiras de espaldar alto, em latão polido, com revestimento em veludo vermelho. Ambas desenhadas por Joaquim Tenreiro. Tais mesas poderiam ser organizadas no ambiente conforme o evento. Ao fundo, há a tapeçaria Vegetação do Planalto Central desenhada em cartão modelo por Burle Marx e executada pelo Atelier Douchez-Nicola. O paisagista escreve para Guilherme Siegfried Marx, em 19 de março de 1966:

66 No Relatório de Despesas de Wladimir Murtinho, consta duas obras de Milton Dacosta, Castelo em cinza e vermelho e Madona. Não se sabe se tal pintura é Madona ou se Madona foi um dos nomes da pintura que atualmente é nomeada como Figura.

67 Vide ALMEIDA, Duílio de. O que ver no Itamarati. Jornal Correio Braziliense, Brasília, 19 de abril de 1969, Caderno 2, p. 13. Não foram encontradas imagens ou descrições sobre a localização desta escultura no pavimento. 
Terminei os cartões para as tapeçarias de Brasília. São cinco, ao todo, e medem 4,2 x 5,2 m. Mando alguns slides que Adélio fez, a fim que vocês possam ter uma ideia da composição. Creio que os resultados são positivos e há qualidades maravilhosas. Foi um grande esforço que desprendi, pois pintei-os todos aqui, no ateliê, num espaço exíguo e, apesar disso, eles se ligam entre si e, se houver bons artesãos, poderão adquirir qualidades ainda maiores. Wladimir Murtinho ainda não sabe se serão feitas aqui, ou em Portugal, na Beiriz. (DOURADO, 2014, p. 204)

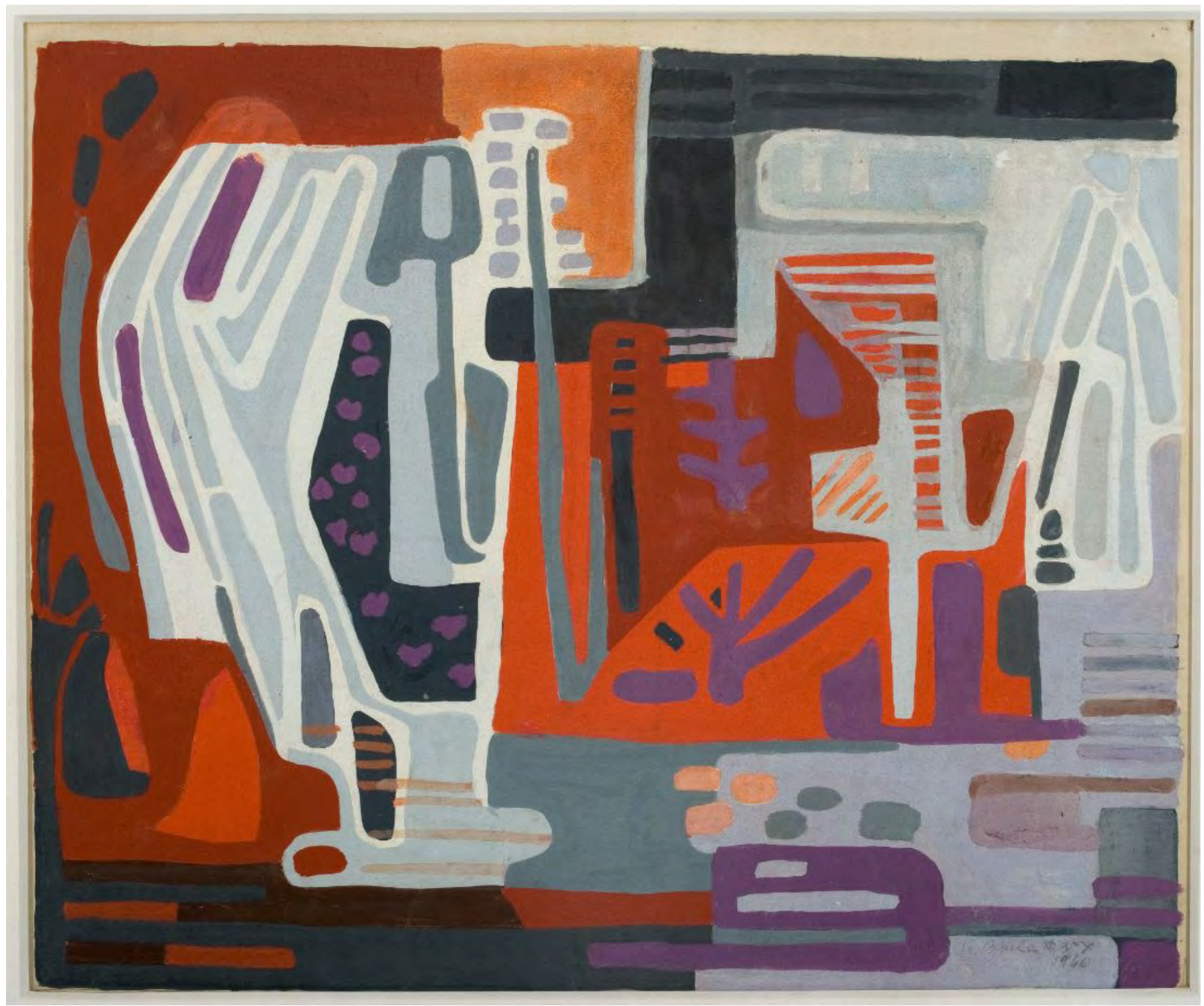

Figura 97: Cartão modelo da tapeçaria Vegetação do Planalto Central, Roberto Burle Marx, 1960. Fonte: João Luiz Musa/Itaú Cultural. 
4. OS ESPAÇOS PALACIANOS / 165

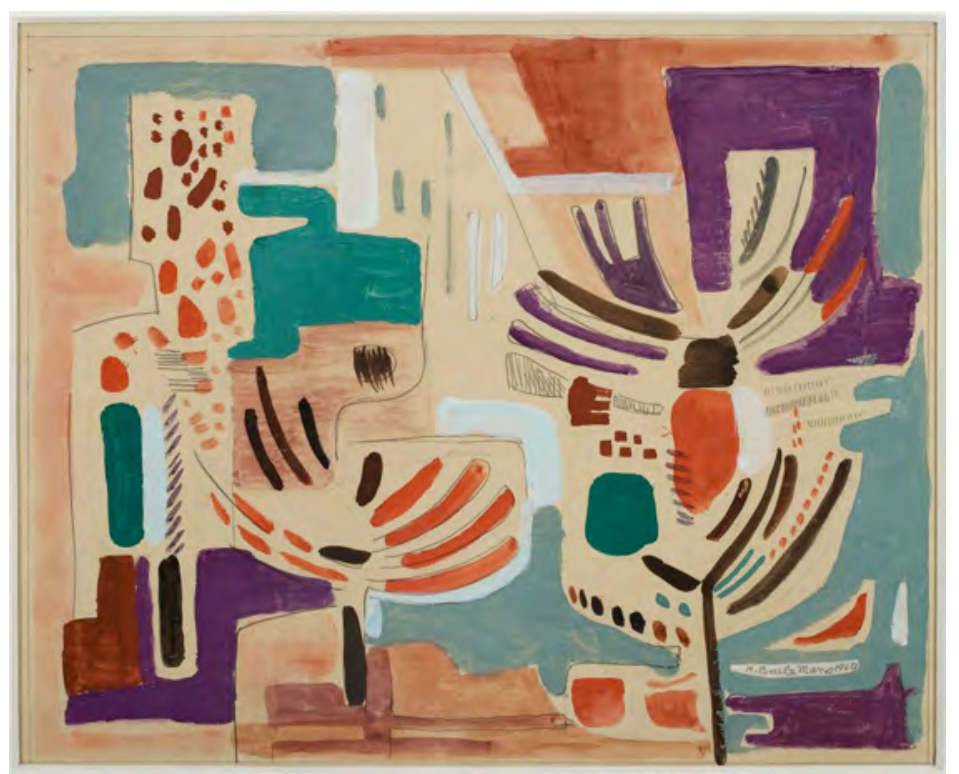

Figuras 98: Cartão modelo da tapeçaria Vegetação do Planalto Central, Roberto Burle Marx, 1960.

Fonte: João Luiz Musa/Itaú Cultural.

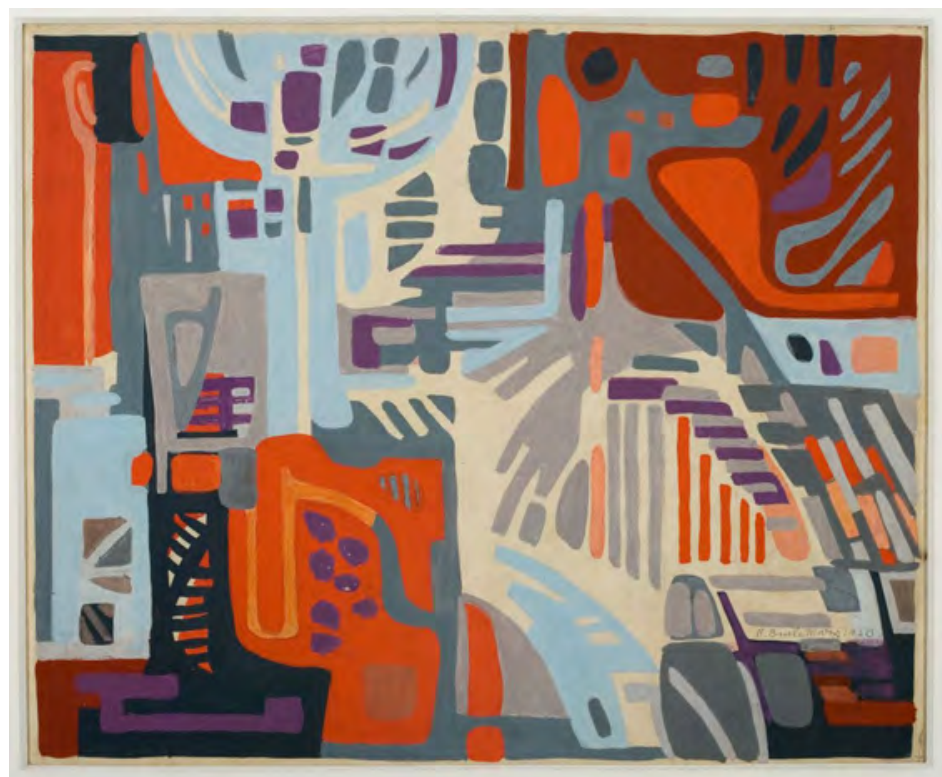

Figuras 100: Cartão modelo da tapeçaria Vegetação do Planalto Central, Roberto Burle Marx, 1960. Fonte: João Luiz Musa/Itaú Cultural.

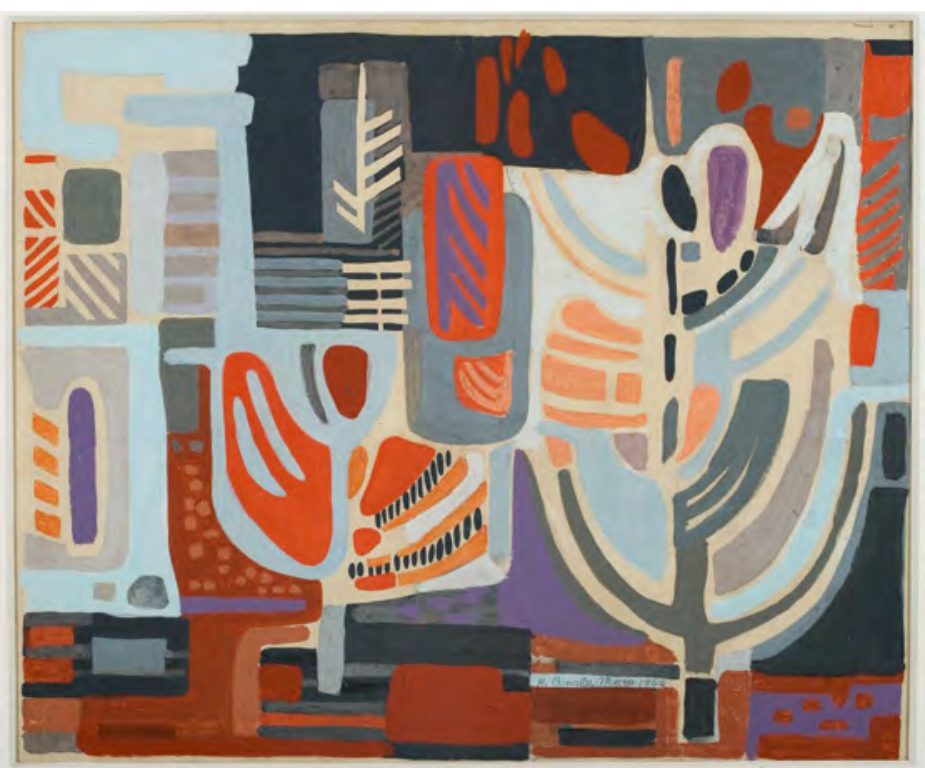

Figuras 99: Cartão modelo da tapeçaria Vegetação do Planalto Central, Roberto Burle Marx, 1960. Fonte: João Luiz Musa/Itaú Cultural.

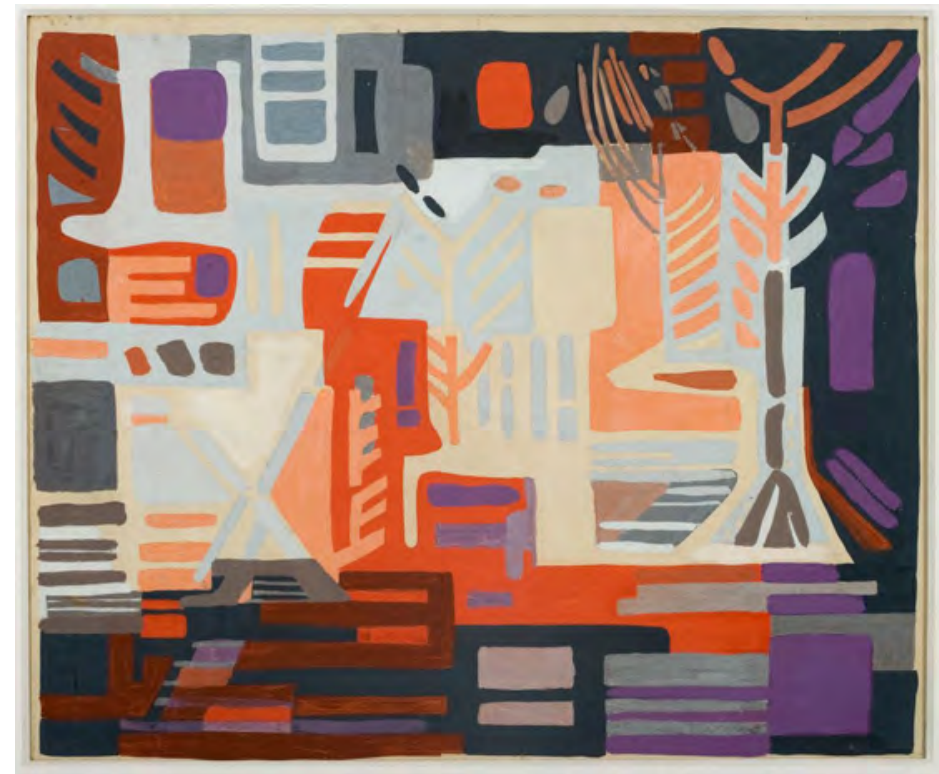

Figuras 101: Cartão modelo da tapeçaria Vegetação do Planalto Central, Roberto Burle Marx, 1960. Fonte: João Luiz Musa/Itaú Cultural. 


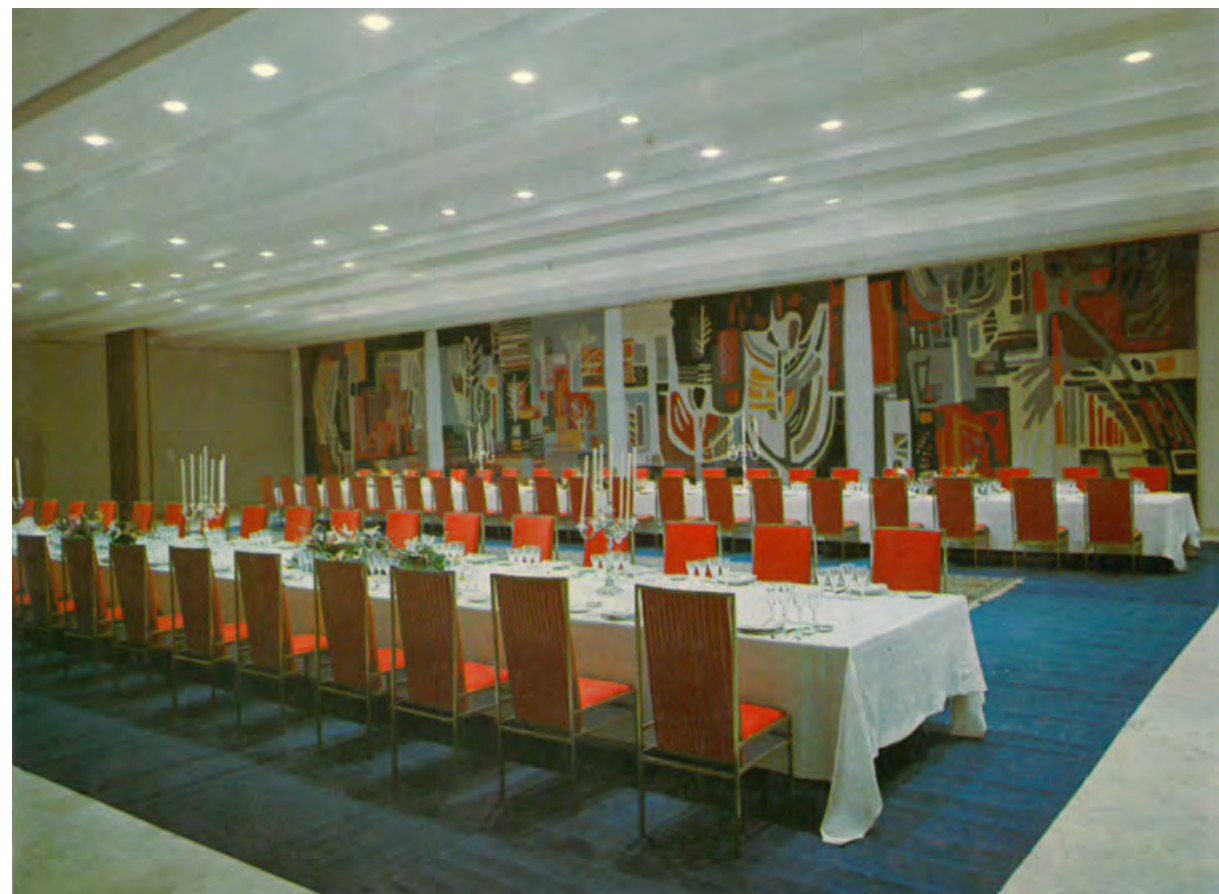

Figura 102: Salão de Banquetes, autor desconhecido, datação não identificada. Fonte: Acervo Antonio Carlos Suster Abdalla.

Uma área destinada para o depósito de cadeiras e a cozinha estão atrás do Salão de Banquetes (Figura 87). Ao lado, há a Sala Bahia, para 12 pessoas, com mesa em jacarandá ovalada para 12 pessoas e 14 cadeiras em jacarandá e palhinha com espaldar alto, nomeadas como Cadeira Bahia, desenhadas por Bernardo Figueiredo ${ }^{68}$ (Figura 103). O teto é originário de uma fazenda de Paracatu, em Minas Gerais, do século XVIII.

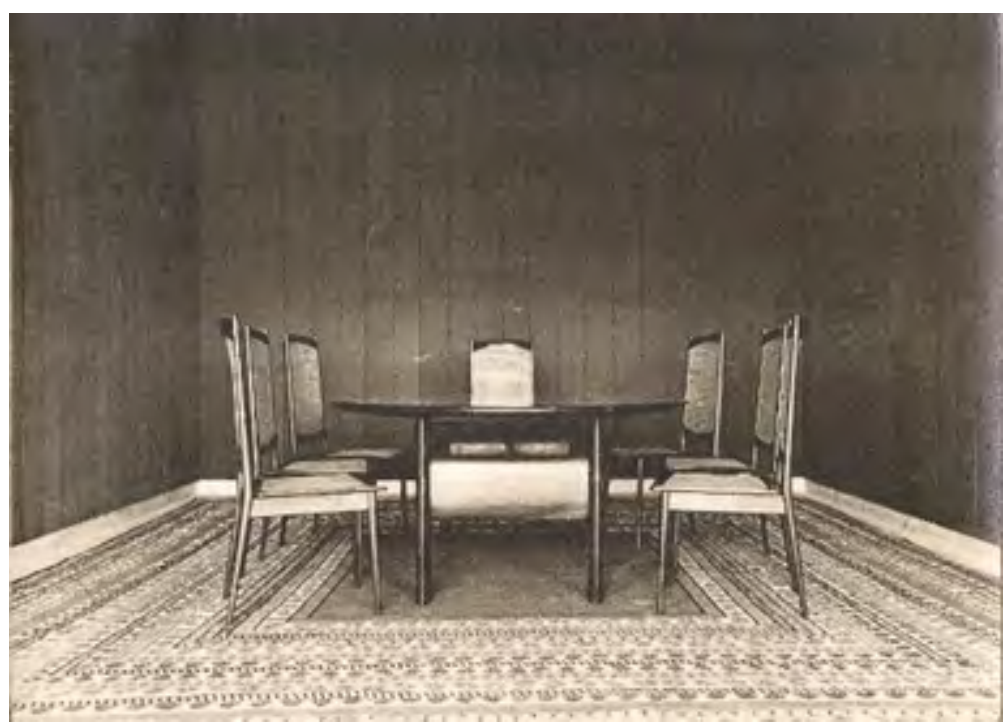

Figura 103: Sala Bahia, Bernardo Figueiredo, datação não identificada. Fonte: Acervo Bernardo Figueiredo. 


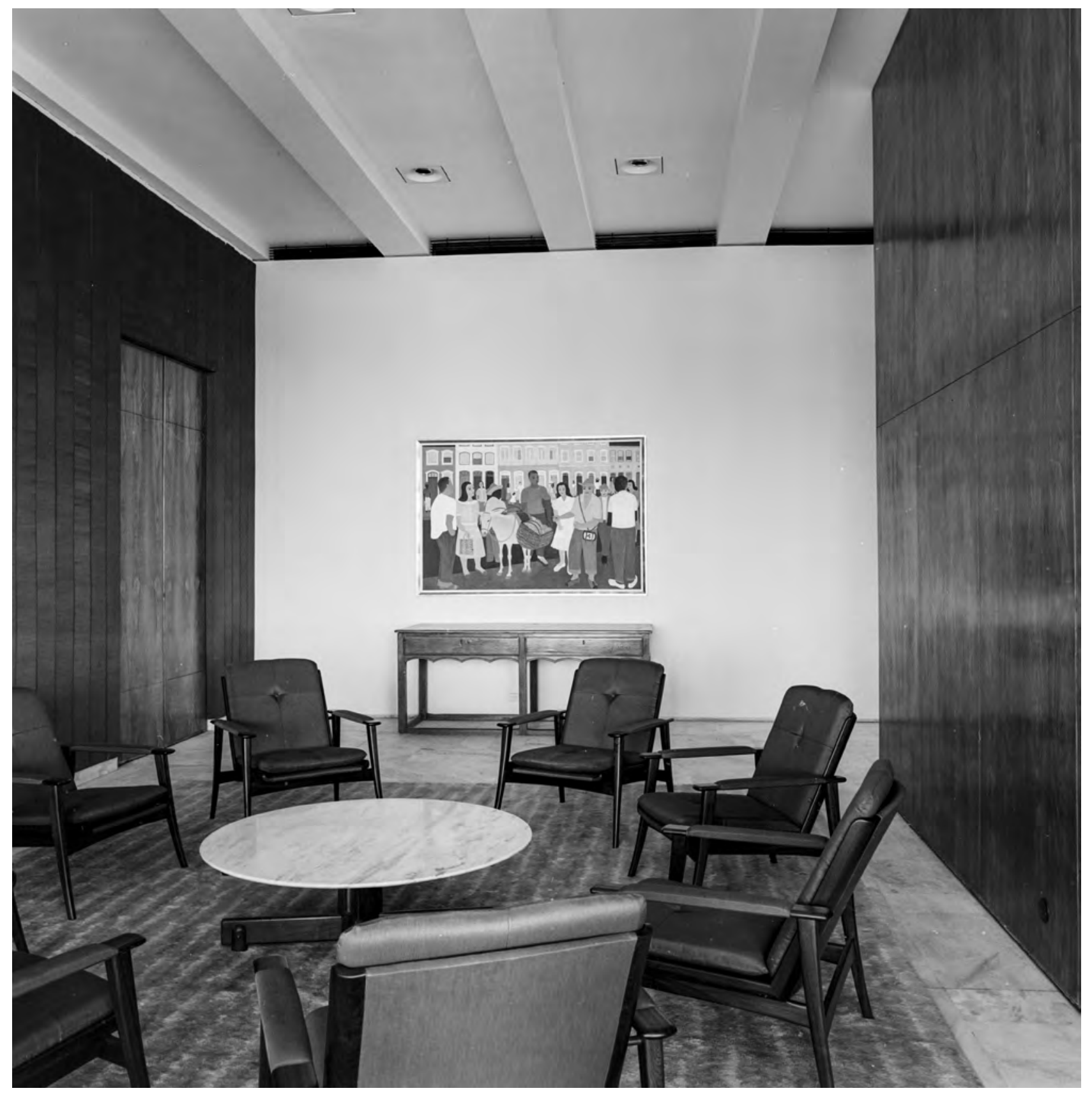

Figura 104: “Cena de rua”, Djanira, Marcel Gautherot, c.a. 1968. Fonte: Instituto Moreira Salles.

A Sala Rio de Janeiro, destinada para 30 pessoas, encontra-se ao lado da Sala Bahia. Segundo o Relatório de Despesas de Wladimir Murtinho, contava com 24 cadeiras em jacarandá e couro desenhadas por Bernardo Figueiredo.

Ainda neste setor destinado aos eventos para uma quantidade reduzida de pessoas, temos a Sala de Estar (Figura 104), composta pelo aparador do século XVIII próximo à parede e a pintura Cena de rua, de Djanira, Poltronas Leve, de Bernardo Figueiredo, e uma mesa de centro. Não há referências claras a estas peças no Relatório de Despesas do Murtinho. 


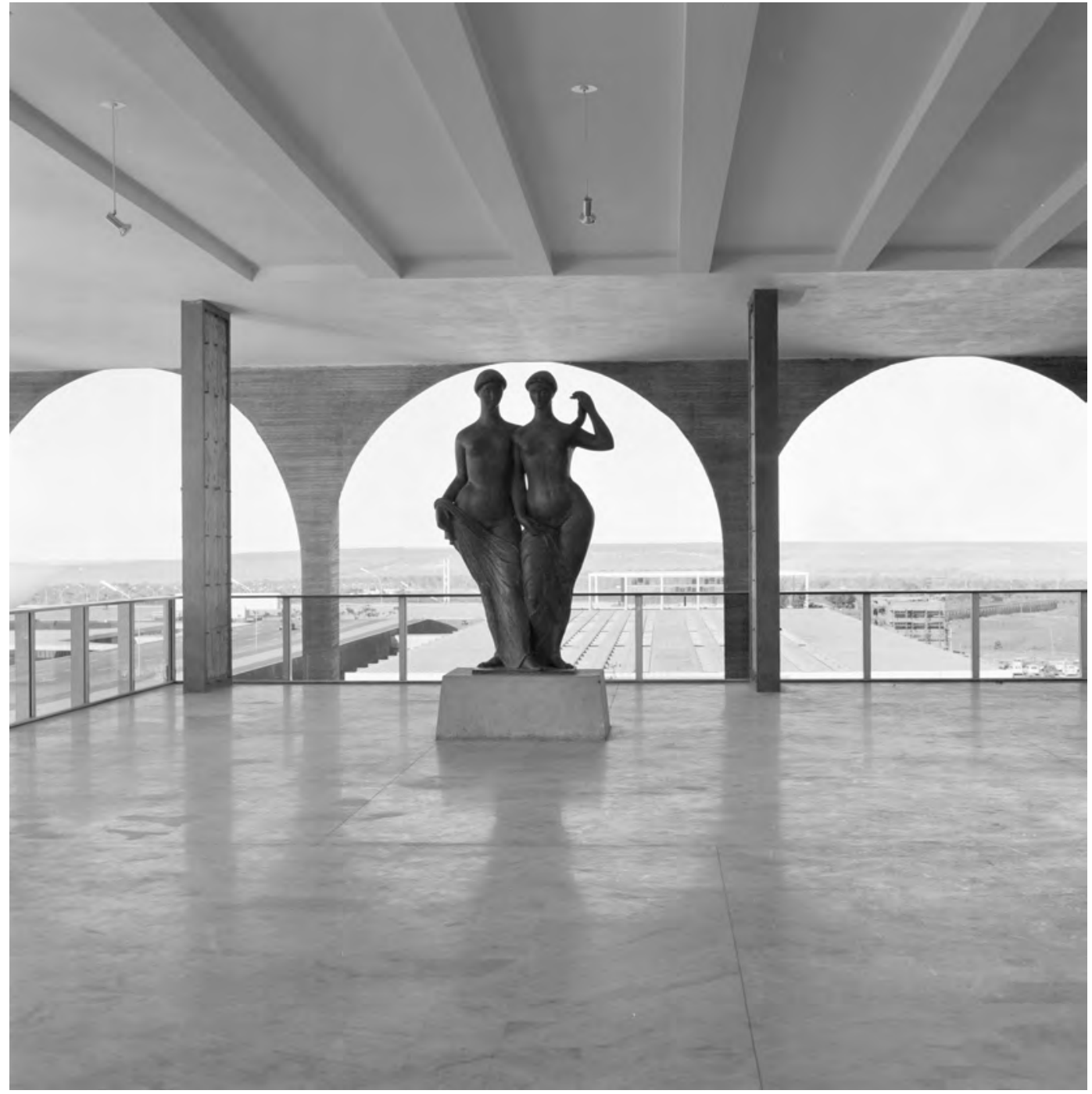

Figura 105: "Duas figuras femininas", Alfredo Ceschiatti, Marcel Gautherot, c.a. 1968. Fonte: Instituto Moreira Salles.

Por fim, o terraço, também chamado como Salão Nobre ${ }^{69}$, cumpre duas funções: a de varanda e a de sala de banquetes para eventos com grande número de convidados, em que: "Há um jardim imenso no centro, onde foram estudadas posições de vento e chuva. O teto é solar. Por trás do jardim das Duas Irmãs de Ceschiatti - fundição Zanir do Rio de Janeiro."7o

A escultura Duas figuras femininas, de Alfredo Ceschiatti, está no Relatório de Despesas de Wladimir Murtinho como obra de arte integrada à arquitetura. Também foram compradas 420 cadeiras de desenho dinamarquês, mas produzidas no Brasil, em madeira eferro com estofamento de camurcim e 75 mesas desenhadas por Bergmiller.

69 Em um projeto de 1965, o Salão Nobre estava localizado onde hoje está a Galeria dos Tratados. Em outro projeto sem data, também consta que o Salão Nobre seria onde está o atual Salão de Baile.

70 ALMEIDA, Duílio de. O que ver no Itamarati. Jornal Correio Braziliense, Brasília, 19 de abril de 1969, Caderno 2, p. 13. 
4. OS ESPAÇOS PALACIANOS / 169

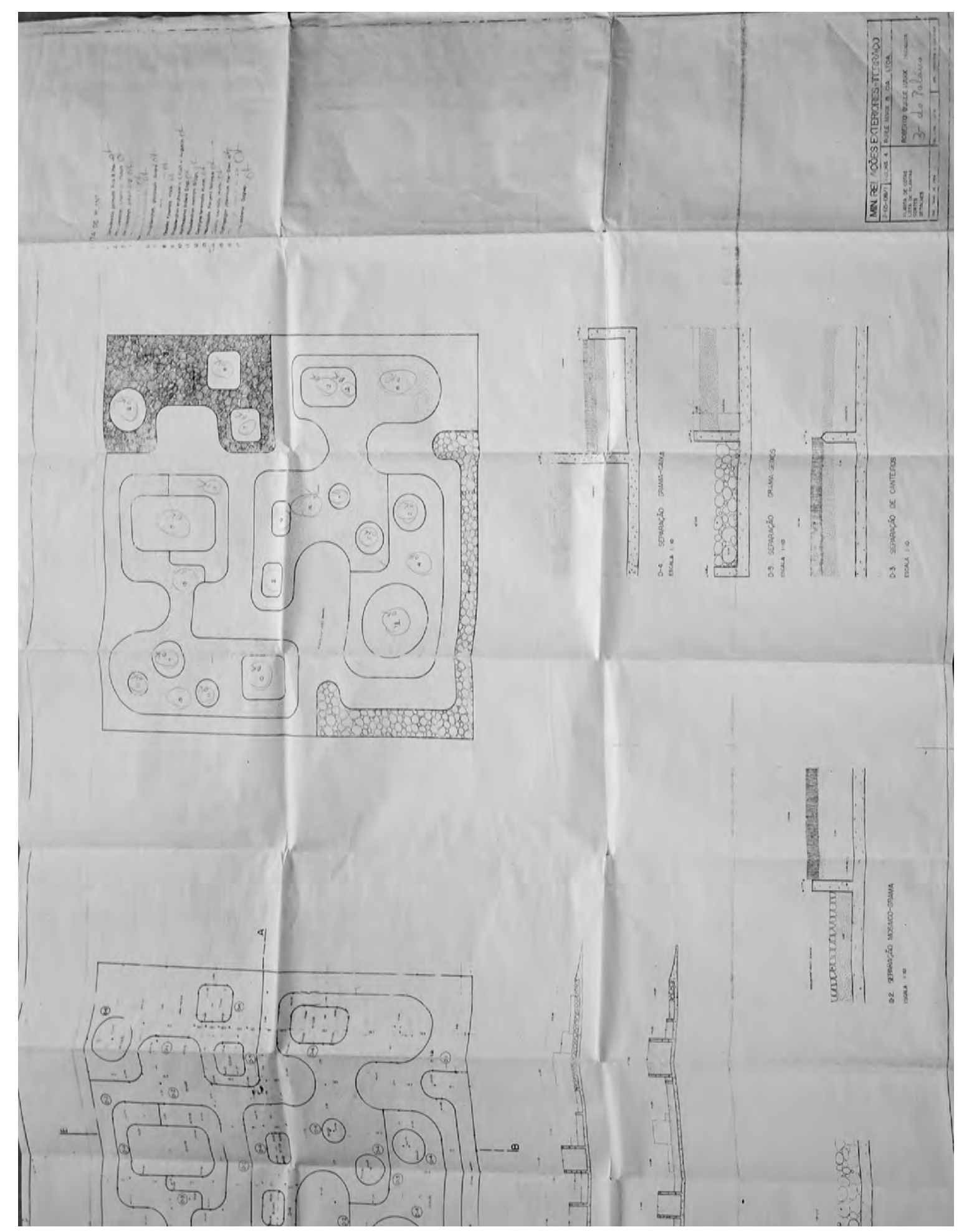

Figura 106: Planta de cotas - 30 Pavimento, Roberto Burle Marx, 1966. Fonte: SARQ. 


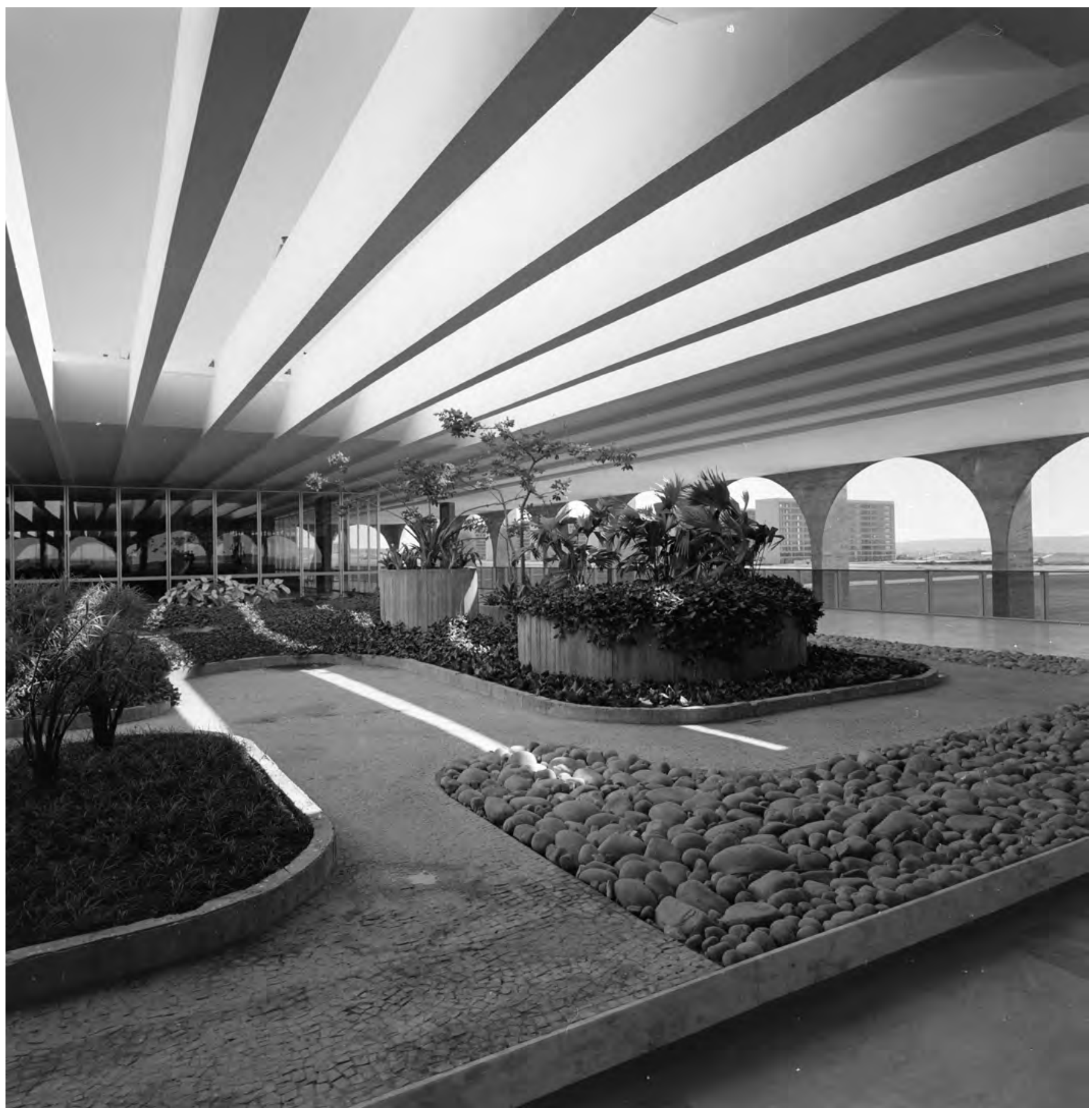

Figura 107: Jardim do Terceiro Pavimento, Roberto Burle Marx, Marcel Gautherot, c.a. 1968. Fonte: Instituto Moreira Salles. 
O jardim suspenso de Burle Marx é o gerador do pavimento. Wladimir Murtinho recorda que no início das conversas com Oscar Niemeyer, desejava um pátio no térreo do palácio ${ }^{71}$. De modo que ao colocar o jardim no andar superior, as recepções ocorrem, de certa maneira, ao ar livre, pois como Jayme Maurício apontou em seu texto, as recepções não poderiam ocorrem nos jardins públicos..$^{72}$ Tal como no jardim do térreo, Burle Marx cria um jardim em que é possível caminhar dentro dele, devido aos seixos. Os canteiros são formas arredondadas que permitem volumes e texturas contrastantes das plantas utilizadas. No meio do jardim, há a escultura Canto à Noite, de Maria Martins, encomendada pelo ministério, conforme consta no Relatório de Despesas. A obra também foi nomeada como $A$ Sinfonia, conforme a reportagem "O que ver no Itamarati", de 19 de abril de 1969, do jornal Correio Braziliense.

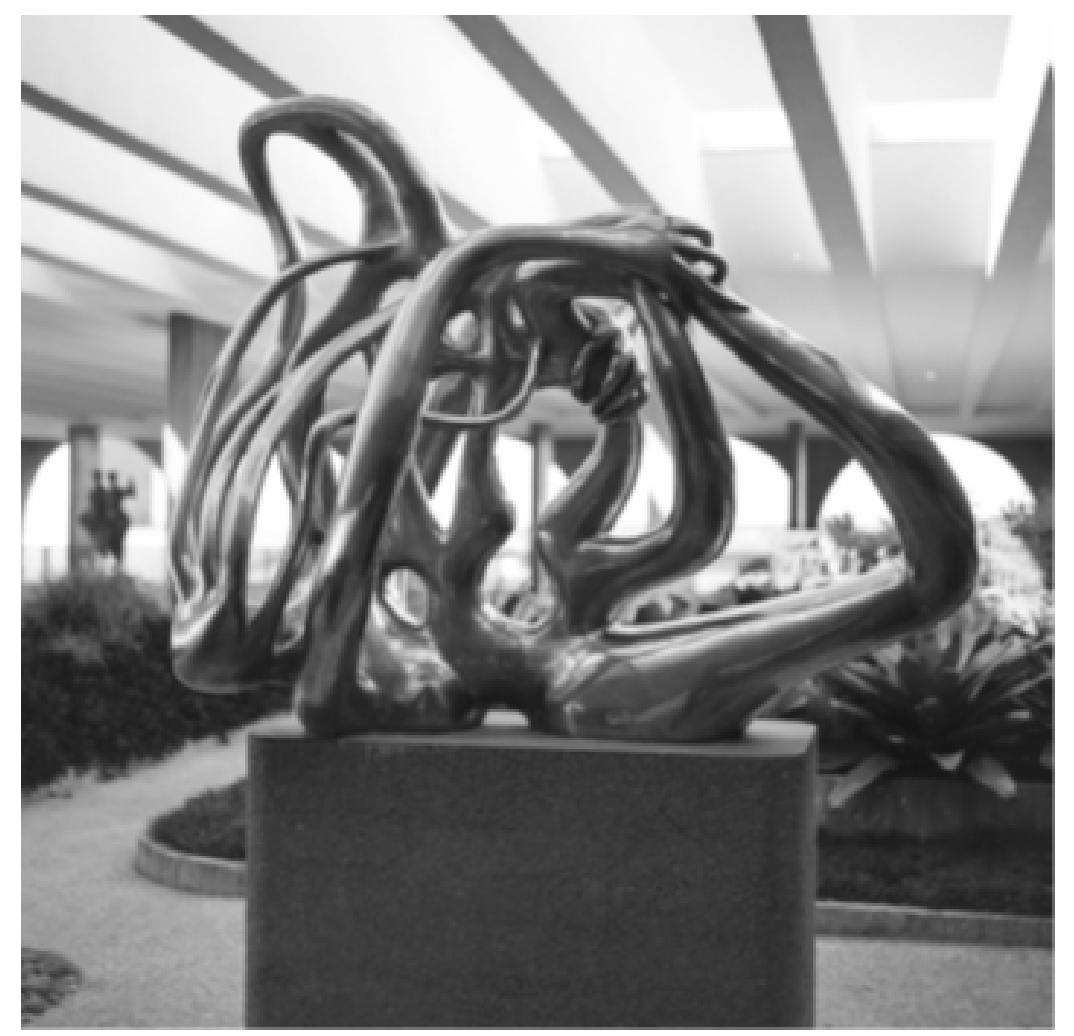

Figura 108: "Canto à noite", de Maria Martins, Marcel Gautherot, c.a. 1968. Fonte: Instituto Moreira Salles.

71 Vide MURTINHO, Wladimir do Amaral. Depoimento Programa de História Oral. Brasília, Arquivo Público do Distrito Federal, 1990. 


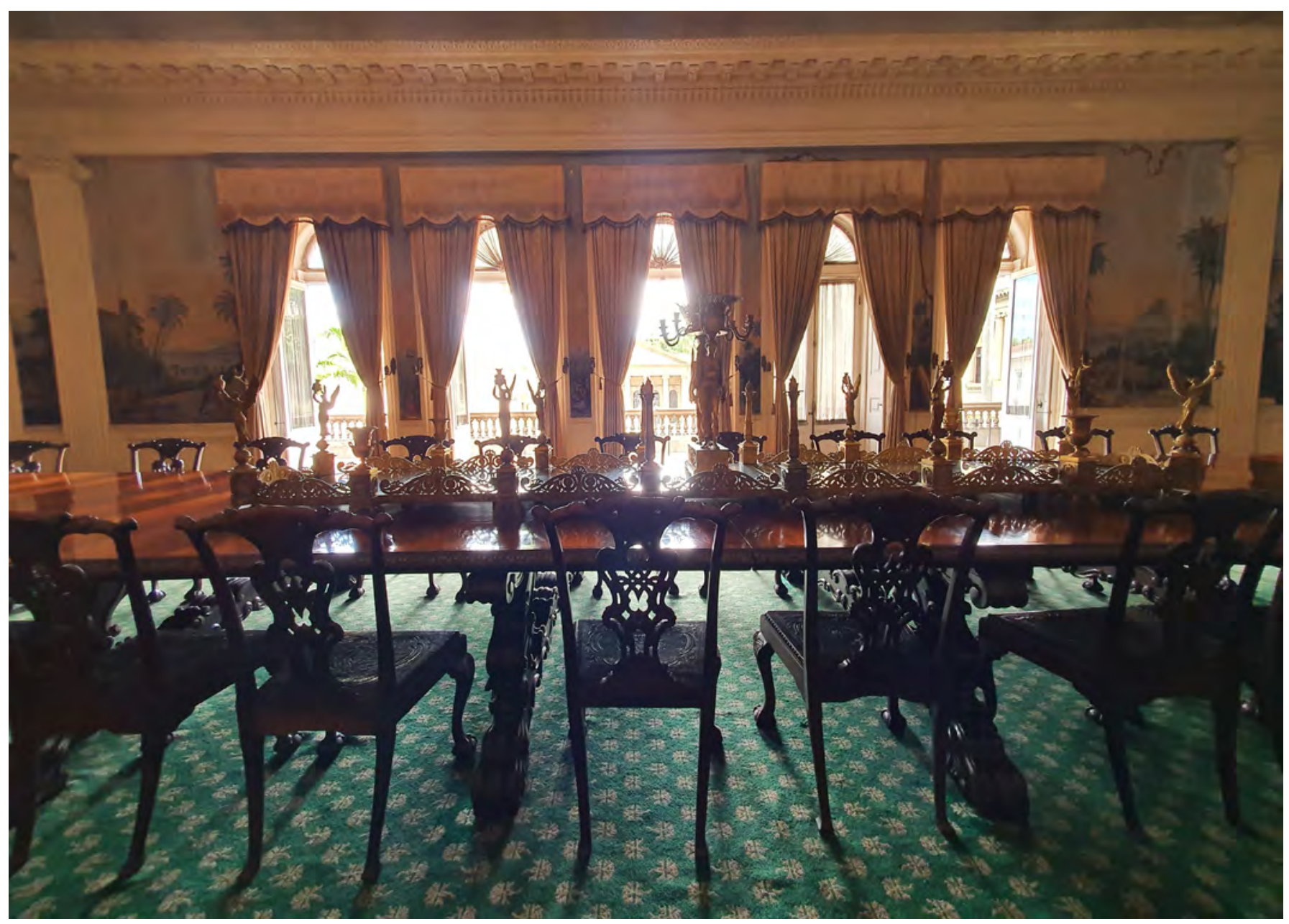

Figura 109: Sala dos Índios, Palácio Itamaraty, Rio de Janeiro. Fonte: Karen Matsuda, 2020.

A vista para a Praça dos Três Poderes não é uma solução totalmente inovadora no palácio. No palácio do Rio de Janeiro, a Sala dos Índios, onde ocorriam os banquetes, tem uma varanda que dá vista para o espelho d'água. É muito provável que Murtinho tinha essa imagem em mente, quando pensava em conjunto com os demais profissionais nas soluções do Terceiro Pavimento. 


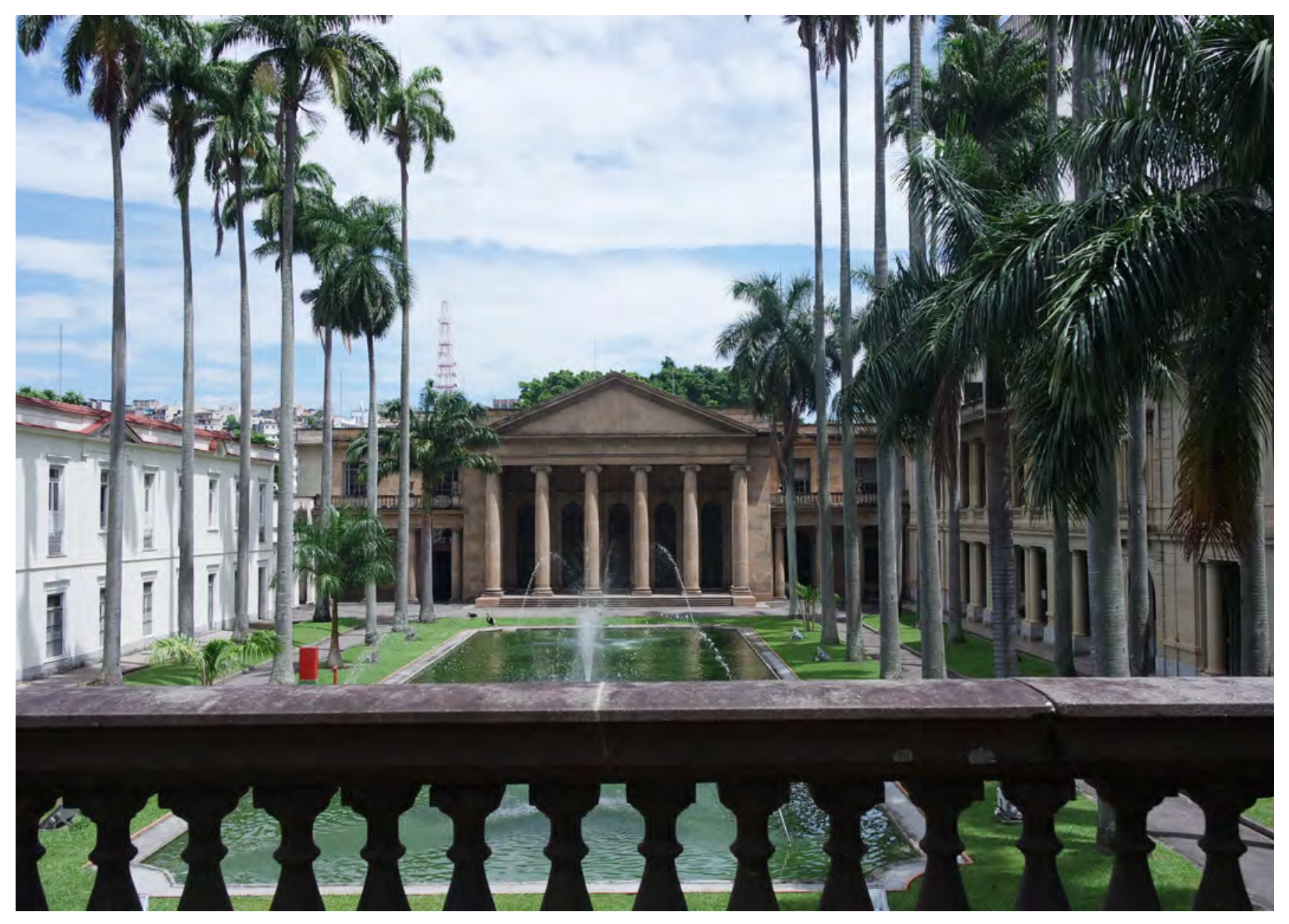

Figura 110: Varanda, Palácio Itamaraty, Rio de Janeiro. Fonte: Karen Matsuda, 2020.

Assim, o Terceiro Pavimento é destinado às recepções, seja em salas de estar ou em salões para banquetes - para muitos ou poucos convidados. É o ambiente mais despojado do palácio e foi composto por diversas peças de mobiliário histórico e moderno. É um pavimento que dialoga também com o palácio carioca. E deseja ser a sala de visitas do Brasil, com vista para a Praça dos Três Poderes - ao ar livre. 


\subsection{SUBSOLO}

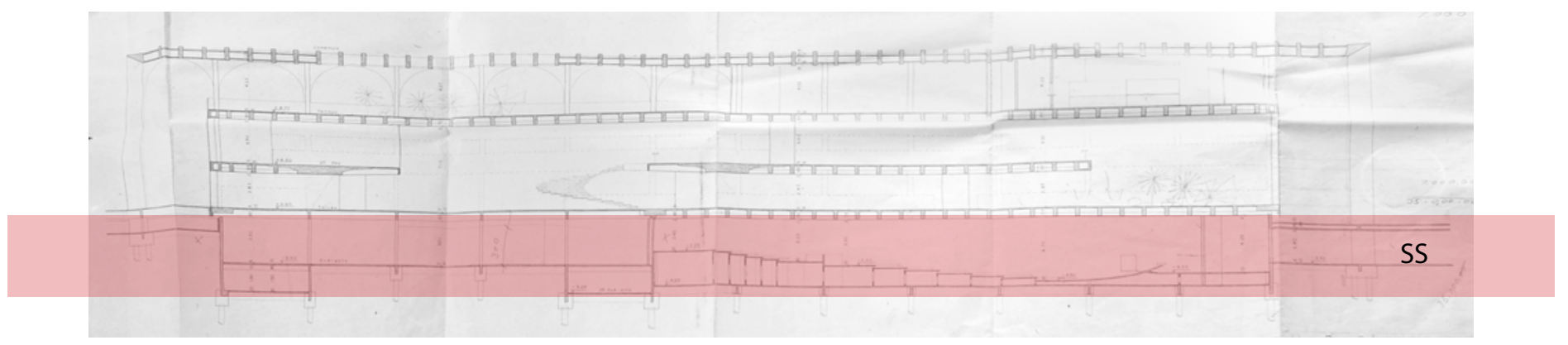

CORTE TRANSVERSAL: INDICAÇÃO ESQUEMÁTICA DO PAVIMENTO 


\section{"O edifício prevê um auditório de palestras, cujo emprego é raro. Não prevê ambientes para reunião frequentíssima de congressos e conferências internacionais.}
A melhor localização para esses ambientes seria o térreo, que é, pelo contrário, inadequado à biblioteca." 73 


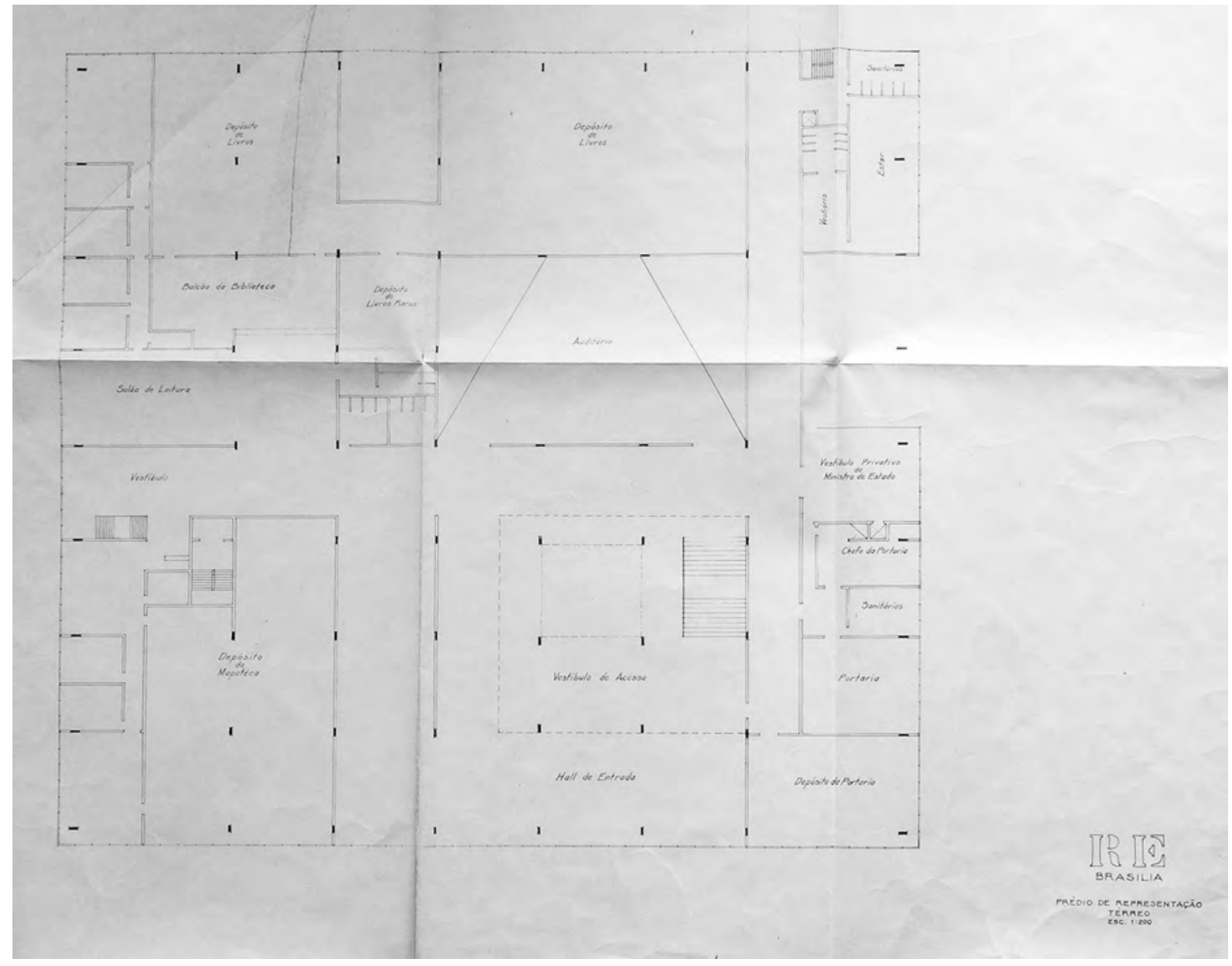

Figura 111: Prédio de Representação - Térreo, datação não identificada. Fonte: SARQ.

A citação que abre este subcapítulo é parte de um dos primeiros programas de necessidades ${ }^{74}$. Os espaços destinados ao auditório, biblioteca, salas de leitura, mapoteca, portaria, vestíbulo e hall estariam no térreo. A planta (Figura 111) apresenta o primeiro projeto do térreo do palácio com a distribuição dos ambientes conforme o programa de necessidades citado.

O auditório, ambiente primordial no momento da elaboração do projeto, está atualmente localizado no subsolo. Lugar destinado às conferências, palestras e eventos comemorativos. Tal espaço poderia ser utilizado pelo próprio Ministério das Relações Exteriores para seus eventos internos, como também para sediar eventos de outras instituições, como foi na Conferência da Bacia do Prata, em abril de 1969, no $12^{\circ}$ Congresso da Federação PanAmericana de arquitetos, em 1970, e na Reunião Técnica Latinoamerica e do Caribe sobre resíduos de pesticidas, em abril de 1972.

74 O documento encontra-se no arquivo do Setor de Arquitetura do Ministério das Relações Exteriores (SARQ). 
4. OS ESPAÇOS PALACIANOS / 177

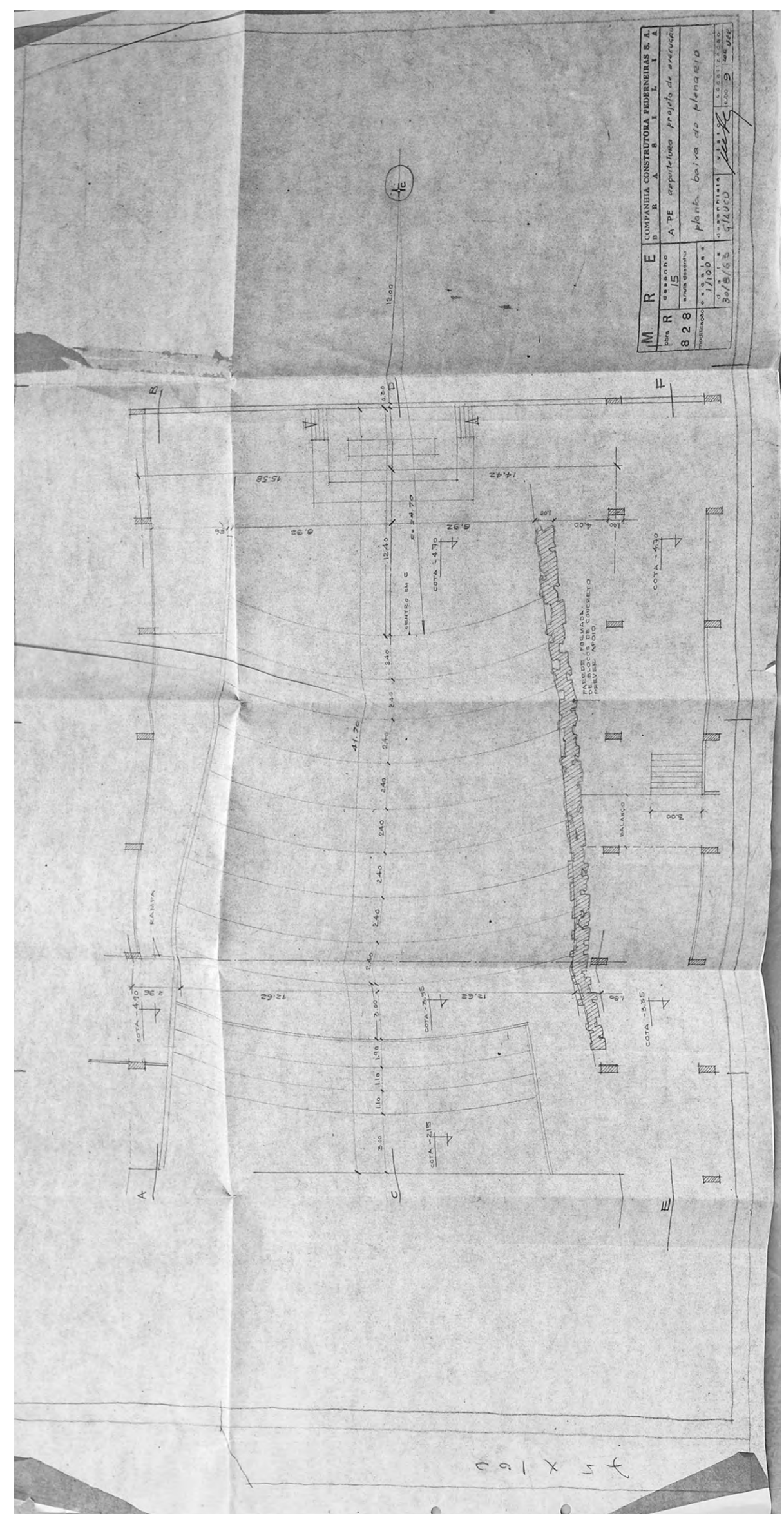

Figura 112: Planta baixa do plenário, 1963. Fonte: SARQ. 


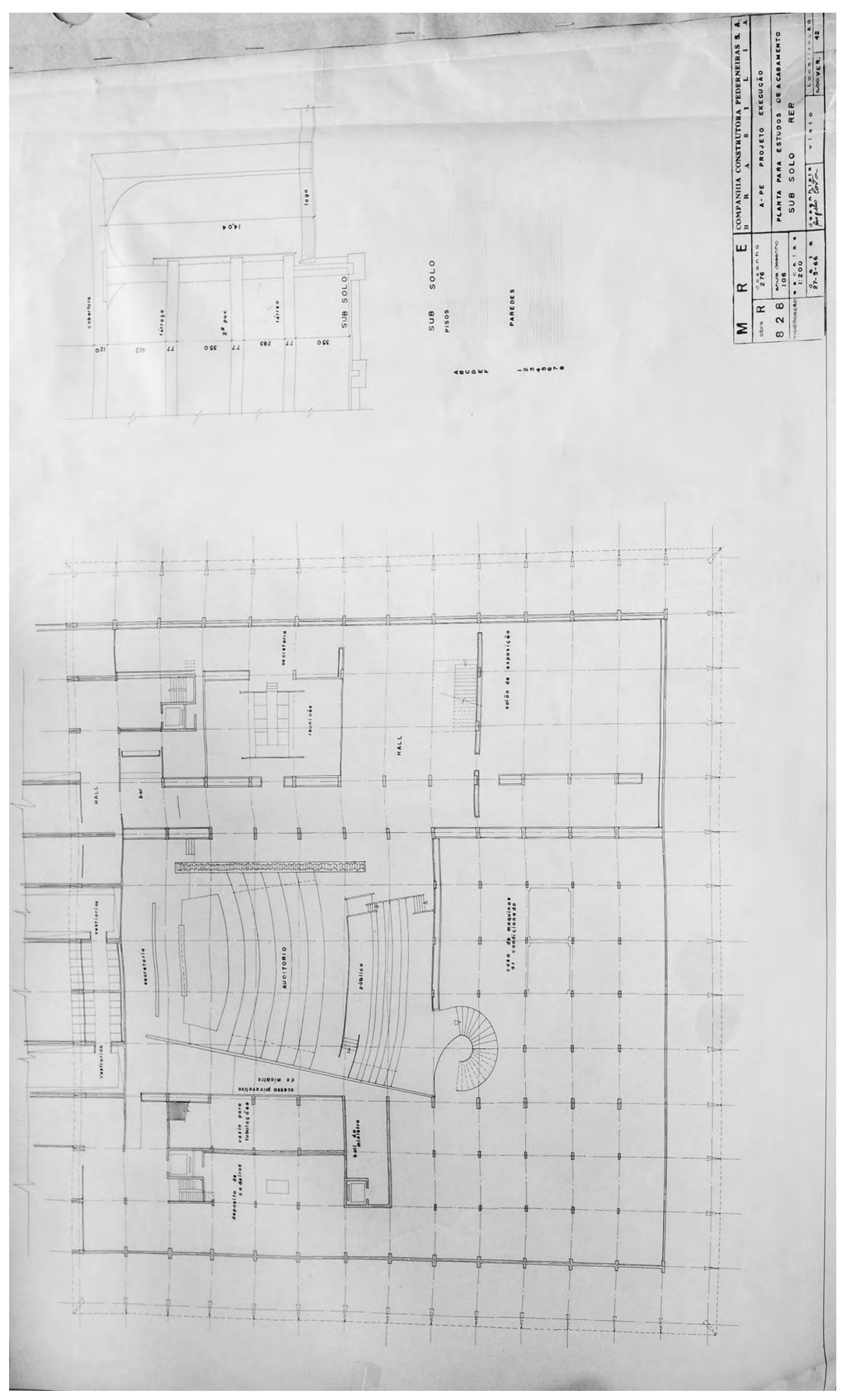

Figura 113: Planta de acabamento - subsolo, 1966. Fonte: SARQ. 
Antes, conforme descreve Jayme Maurício em sua matéria "Palácio Rio Branco, Brasília” na Revista Habitat, em 1959:

A área destinada ao centro de conferências internacionais divide-se entre o andar térreo e o $1^{\mathrm{o}}$ andar, num total de, aproximadamente, $3.000 \mathrm{~m}^{2}$. Compreende as seguintes instalações: a) Sala do plenário com capacidade para 300 delegados e 500 espectadores, b) salas para o secretariado. (MAURÍCIO, 1959)

Posteriormente, o auditório foi pensado para ocupar o subsolo, porém seu formato trapezoidal continuou o mesmo (Figura 111 e Figura 112). No projeto de 1963, o auditório era chamado de plenário e já podemos ver o desenho do Muro Escultórico de Sergio Camargo e a mesa centralizada (Figura 112).

Em outubro de 1963, o subsolo está em construção. A partir de 1964, o projeto começa a ganhar a espacialidade que conhecemos hoje e o térreo é pensado para ser o local destinado às recepções. A biblioteca e a mapoteca, antes destinadas ao mesmo pavimento que o auditório, passam para os edifícios anexos. Em contrapartida, o subsolo ganha outros ambientes, como a sala de exposições (atual Sala San Tiago Dantas), cabines de tradução, duas salas para reunião e salas de apoio. Os serviços de apoio, como o vestiário, copa, cafeteira, sanitários estão localizados no subsolo. Há também uma ligação entre o bloco administrativo e o edifício representativo no subsolo.

Em setembro de 1965, o subsolo já está resolvido tal como conhecemos hoje: auditório em formato de plenário com a escultura Muro Escultórico, hall, sala de exposições, cabines de tradução, serviços de apoio, acesso do Ministro, escada ortogonal e helicoidal para o térreo. A planta de acabamento (Figura 113), de maio de 1966, mostra que a solução da mesa do auditório não estava finalizada, por enquanto era uma mesa retilínea.

Embora o palácio não estivesse pronto, a primeira exposição ocorreu em agosto de 1966 e foi uma retrospectiva sobre Le Corbusier, conforme noticiavam as manchetes do jornal Correio Braziliense: "Obras de Le Corbusier serão expostas no Palácio dos Arcos”, 26 de agosto de 1966, e "Exposição de Le Corbusier mostra futura embaixada da França em Brasília". 


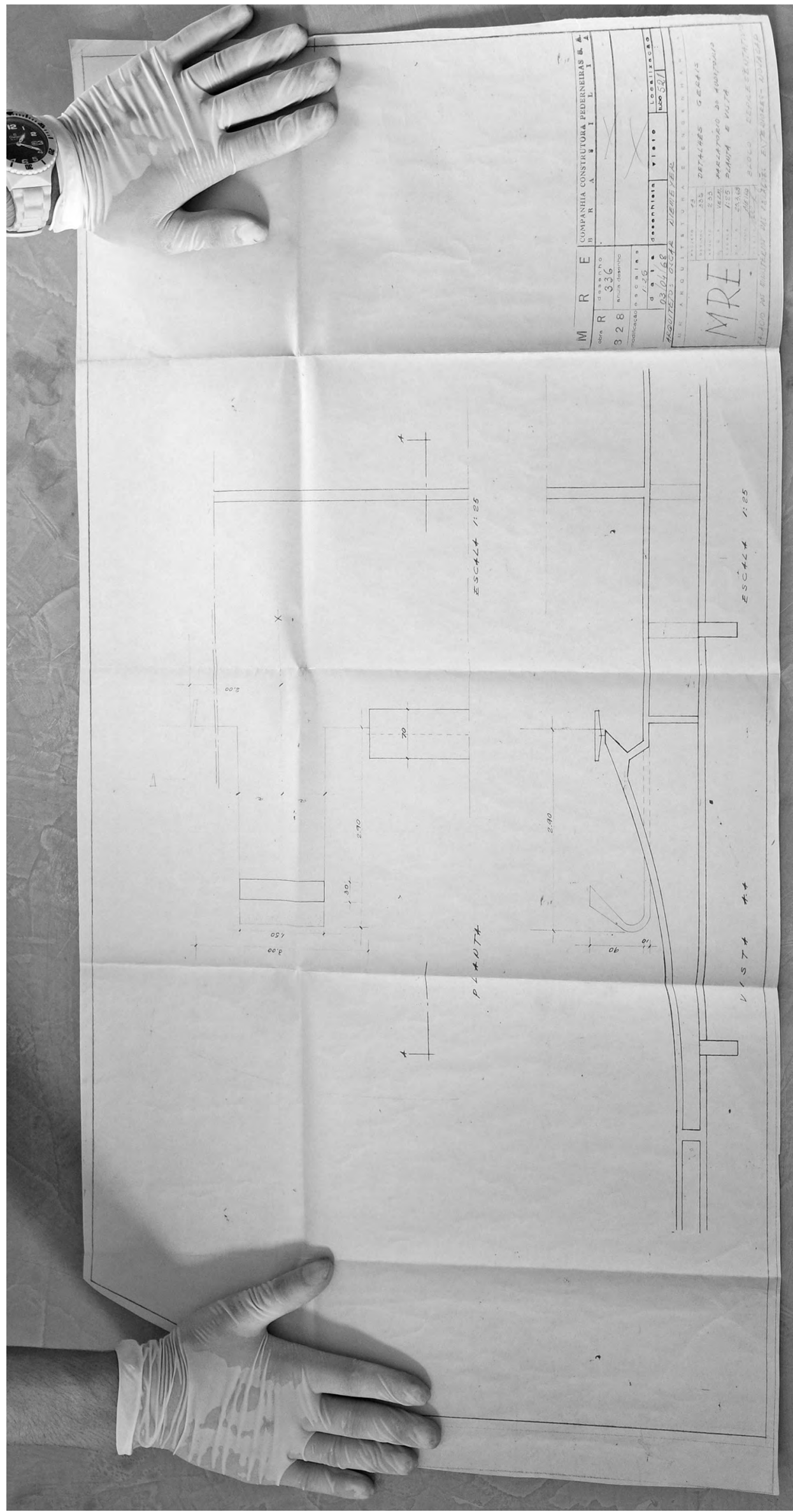

Figura 114: Parlatório do auditório - planta e vista, 1968. Fonte: SARQ. 


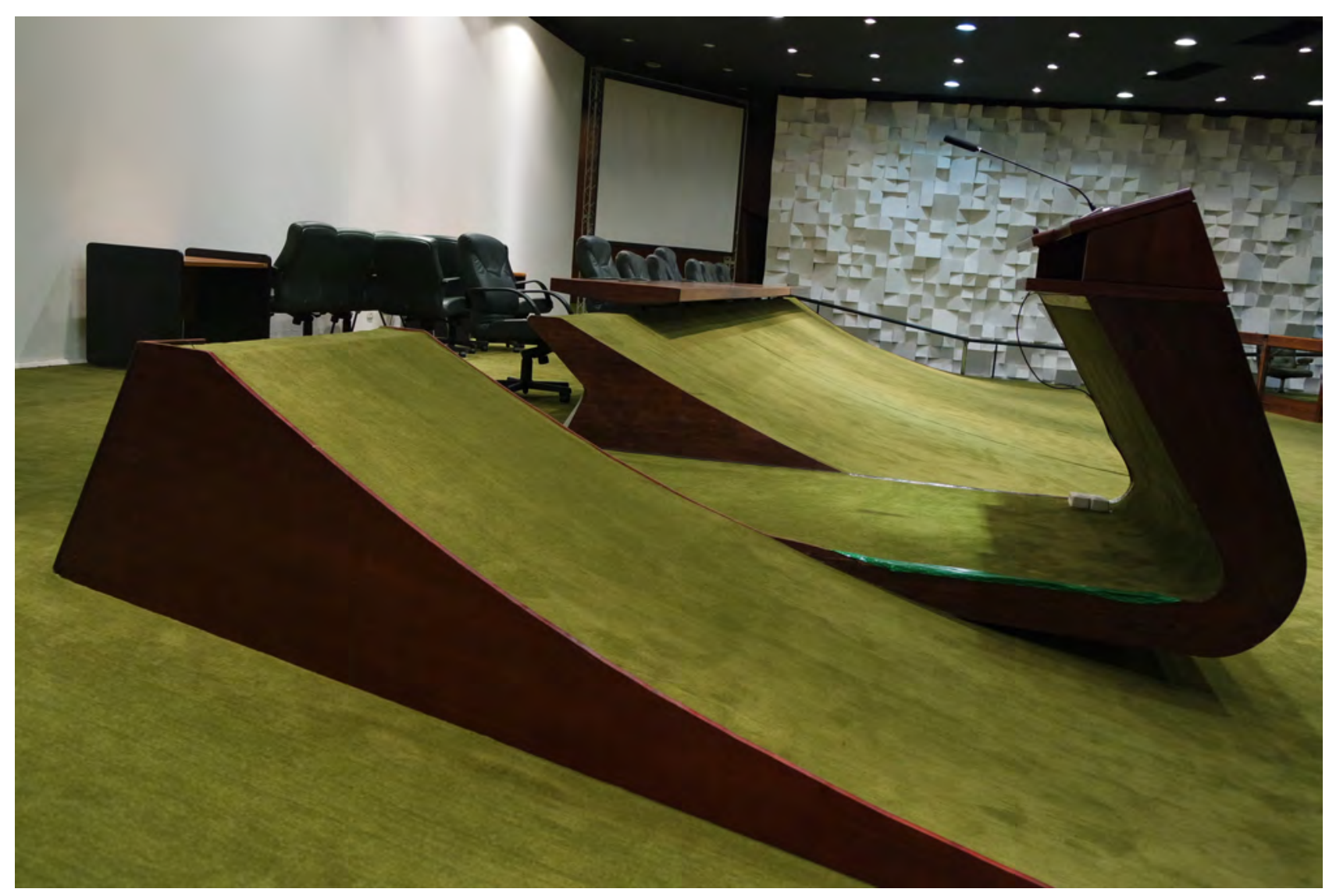

Figura 115: Parlatório. Fonte: Karen Matsuda, 2019.

Em 1968, o desenho da mesa já está resolvido. A partir da ideia de uma rampa cria-se a mesa para os palestrantes e o parlatório. A área destinada à comunicação ganha, assim, expressividade, conforme se vê na planta de detalhes gerais (Figura 114).

Enfim, em 1970, o subsolo, bem como dos demais pavimentos do palácio estavam prontos:

Está ficando uma beleza mesmo o auditório do Palácio do Itamarati. As paredes já foram totalmente revestidas em juta verde e o chão todo atapetado e extremamente macio. O sistema de som já pronto. Iluminação, idem. Falta apenas aparafusar as cadeiras. As seis bólhas de vidro que fecham as cabinas de tradução simultânea são, talvez, a coisa mais original e que mais desperta atenção. Esta foi uma idéia feliz de Rubens Richter. As bólhas, como se sabe, são as mesmas utilizadas por certo tipo de helicóptero. O auditório será inaugurado no dia 20 de abril, com a cerimônia de entrega de diplomas aos 50 concluintes do Curso Rio Branco, turma de $1969 .^{75}$ 


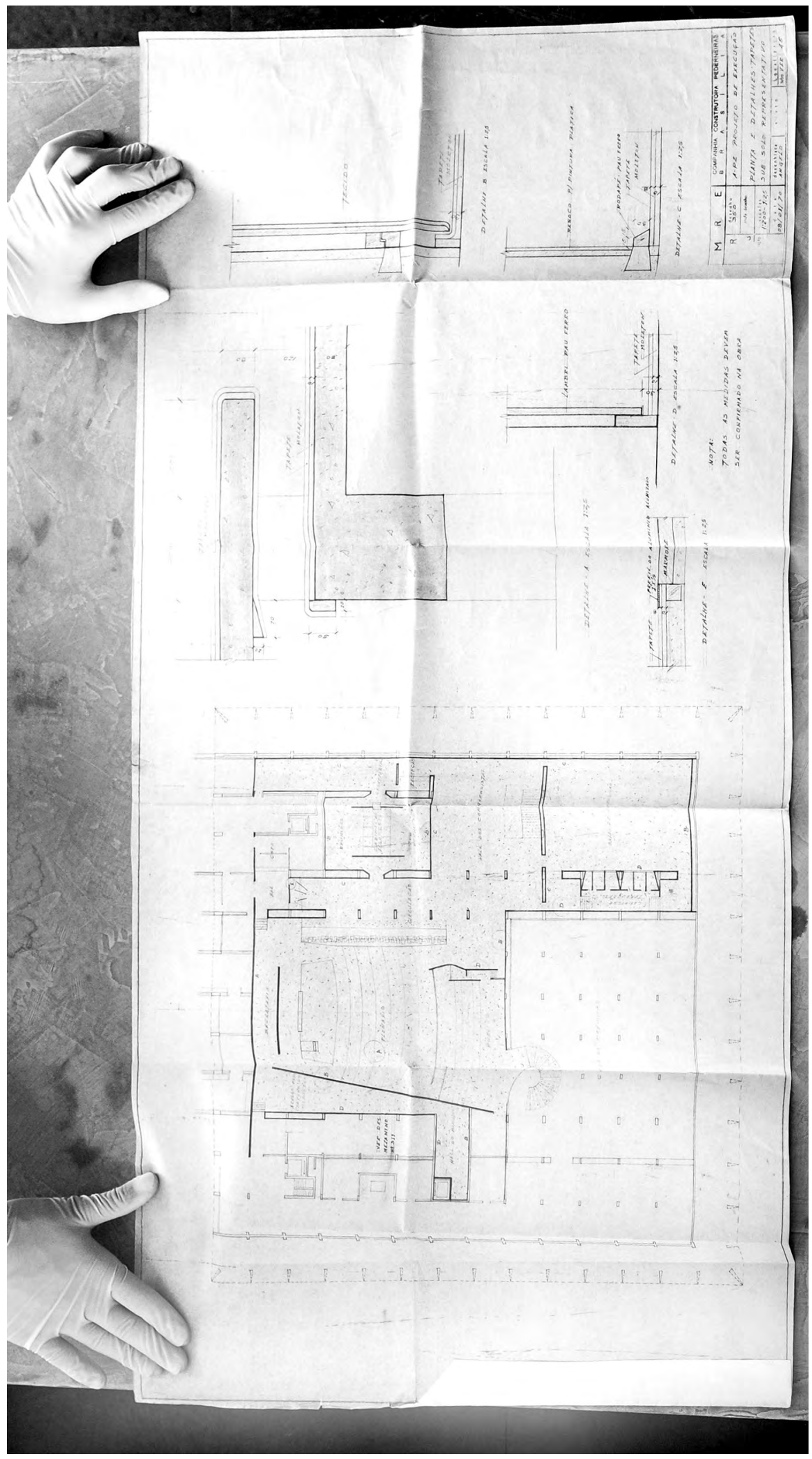

Figura 116: Planta e detalhes - tapetes, 1970. Fonte: SARQ. 
Após a inauguração, o palácio continuou sediando exposições. Em 1970, ocorreu a exposição "Arte Negra do Senegal”. Em 1972, "O espírito criador do povo brasileiro, coleção de Abelardo Rodrigues"; em 1973, a exposição "Museu de Arte de São Paulo Assis Chateaubriand" e em 1974, "14 artistas do brasil moderno". Atualmente, a Sala de Exposições é a Sala San Tiago Dantas onde ocorrem reuniões.

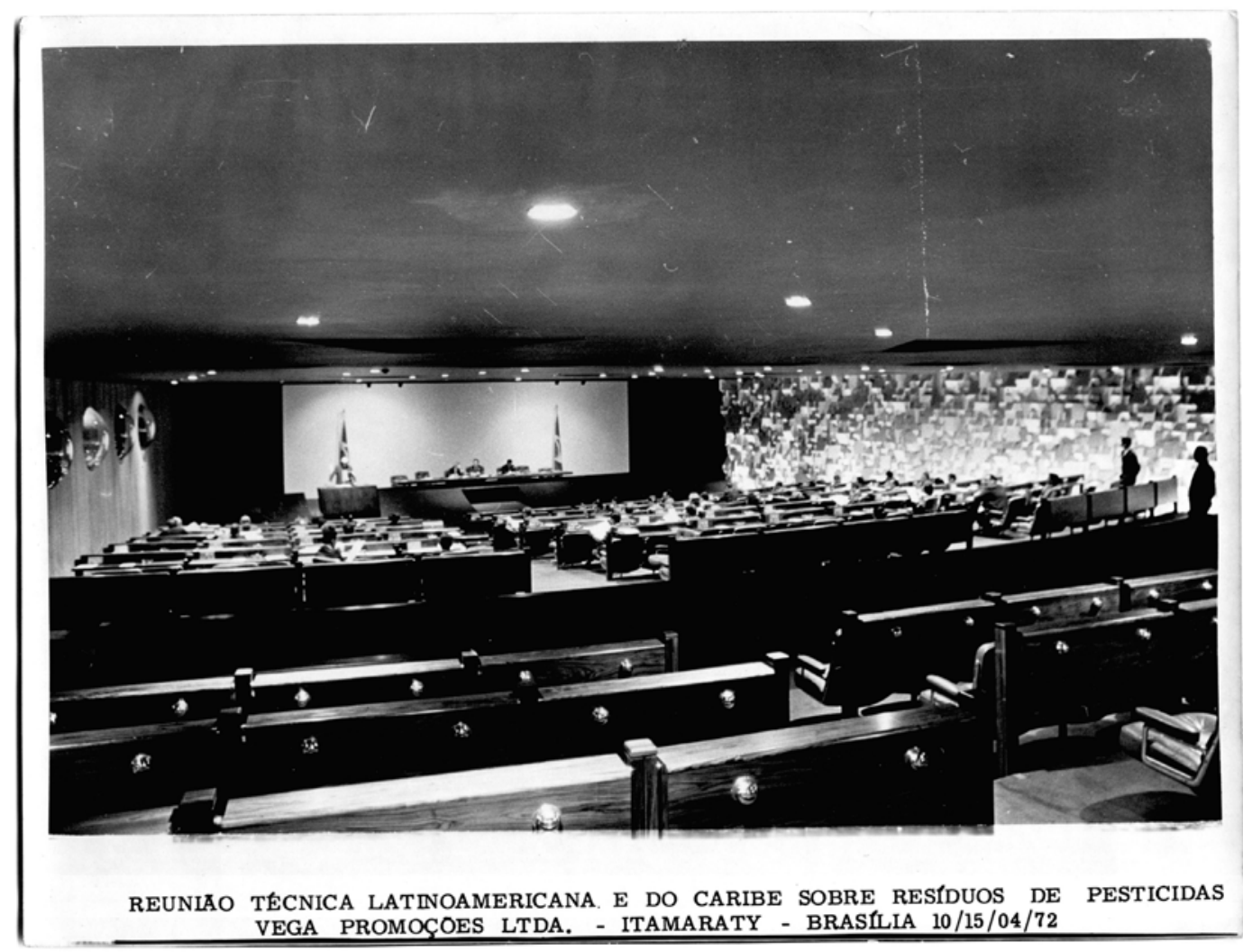

Figura 117: "Muro Escultórico", Sergio Camargo, autor desconhecido, 1972. Fonte: Instituto de Arte Contemporânea (IAC). 
O palácio não foi feito só de peças produzidas por brasileiros. As poltronas do auditório foram encomendas para a Herman Miller ${ }^{76}$ :

Já montadas no auditório as originais poltronas que completam a decoração daquele belo recanto do Palácio do Itamarati. As poltronas são da linha internacional de Herman Muller, sua montagem está a cargo de Móveis Tepermann, de São Paulo. ${ }^{77}$

O auditório é composto por poltronas conjuntas em duas, seis e oito unidades. Há também poltronas com braços. Todas fixadas no chão. Foram feitas em alumínio e couro verde, com desenho de Charles Eames, conhecida como Time Life Executive Chair.

O Muro Escultórico de Sergio Camargo, que separa o auditório do hall, é a única obra do subsolo que foi adquirida até o momento da inauguração do palácio, em 1970, além das poltronas fornecidas pela empresa Herman Miller. Em cartas trocadas entre o Embaixador Wladimir Murtinho e Sergio Camargo, podemos observar que Oscar Niemeyer acompanhava o projeto: "O Oscar gostou muito do fragmento do muro e agora falta-nos apenas a aprovação da Comissão do Itamaraty" 78 . Como nos conta uma reportagem sobre o palácio no Correio Braziliense:

O subsolo será todo ocupado com o plenário com uma capacidade superior ao da Câmara dos Deputados. Uma parede escultural de 27 metros de comprimento por 4 de altura já está sendo executada por Sergio Camargo. Tem uma dupla finalidade: decoração e acústica. ${ }^{79}$

A obra executada em concreto e prevista por conta da obra foi pensada pela Comissão de Transferência como Obra de Arte Integrada.

76 Nos documentos citados, a gráfia da empresa Herman Miller está como Herman Muller.

77 Correio Diplomático. Jornal Correio Braziliense, Brasília, 11 de abril de 1970, p. 5.

78 A carta escrita por Wladimir Murtinho para Sergio Camargo, em 7 de janeiro de 1966, está no acervo do Instituto de Arte Contemporânea (IAC). 
4. OS ESPAÇOS PALACIANOS / 185

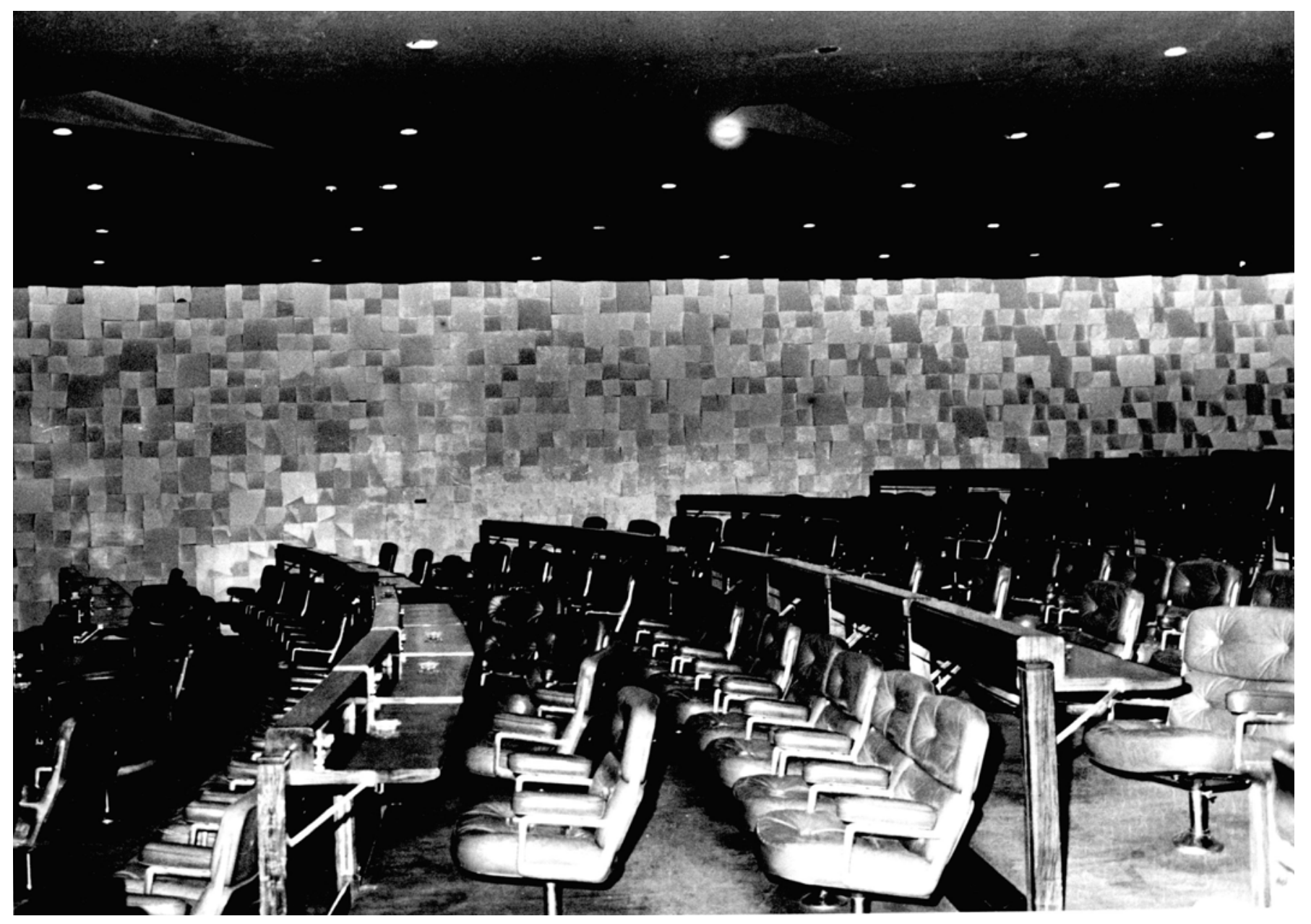

Figura 118: "Muro Escultórico", Sergio Camargo, autor desconhecido, datação não identificada. Fonte: Instituto de Arte Contemporânea (IAC). 


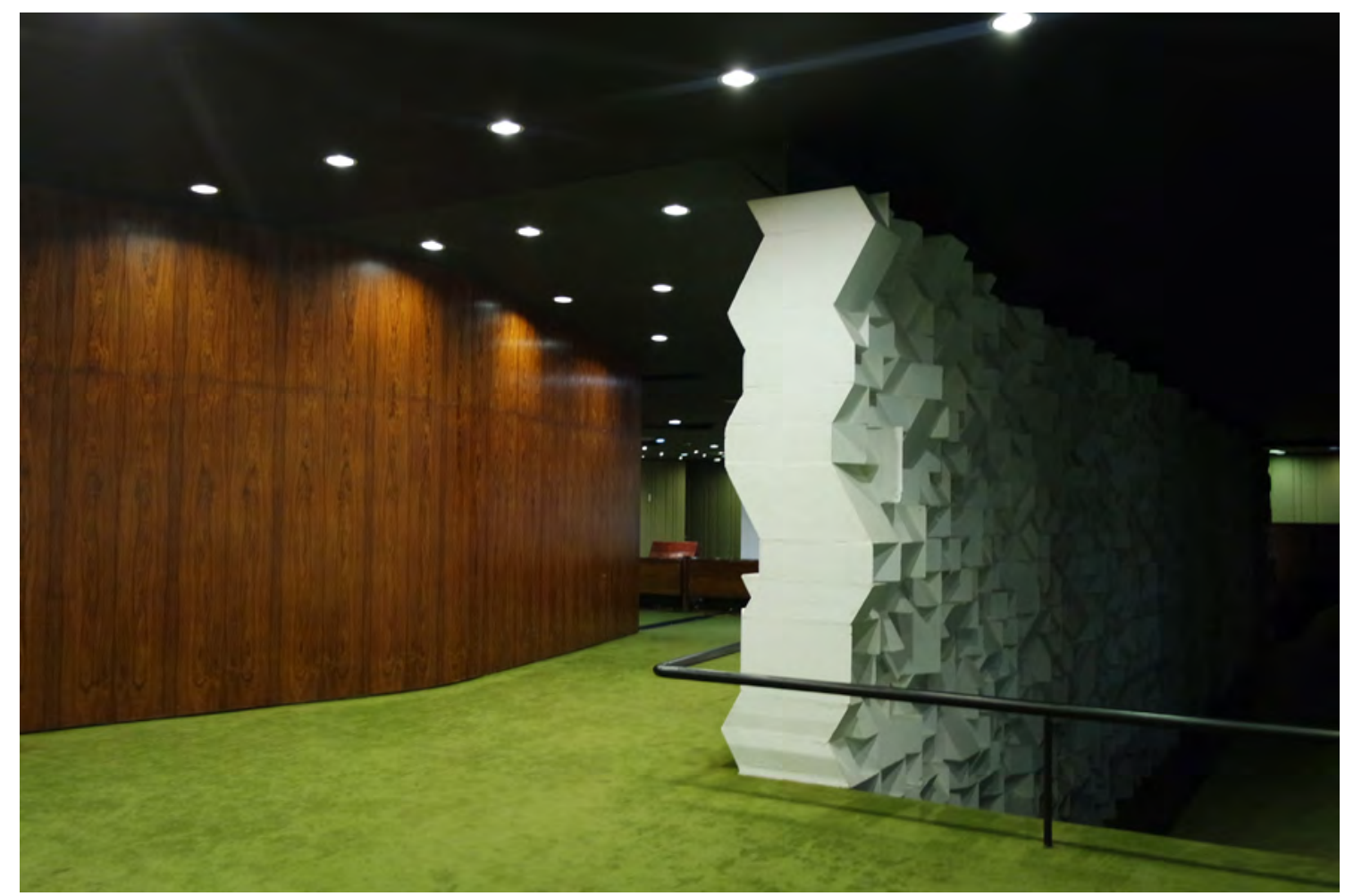

Figura 119: Auditório. Fonte: Karen Matsuda, 2019.

O Muro Escultórico, de Sergio Camargo, é formado por cubos de diversos tamanhos com cortes na horizontal, vertical ou diagonal. Assim, a sombra é gerada a partir da relação entre a luz que incide nos volumes. O resultado é o movimento de cintilar, que necessita do caminhar do observador para se completar enquanto fruição. Nas palavras de Ronaldo Brito:

A leitura deve ser ao mesmo tempo metódica e selvagem, descontínua e organizada, ágil e insistente, repetida de outra. Leitura em função de um método que atua por oposições, por rupturas de elementos, em função de um sistema rigoroso, mas que inclui a própria abertura, a sua própria negação enquanto sistema. (BRITO, 2006, p. 311)

Os espaços foram criados a partir do diálogo entre o interno e o externo. Ambiente fechado por vocação, o auditório é delimitado pelo Muro Escultórico, de Sergio Camargo, e possui uma abertura de modo que quem está em determinado lugar do hall pode ver a mesa e o parlatório do auditório (Figura 119). 
4. OS ESPAÇOS PALACIANOS / 187

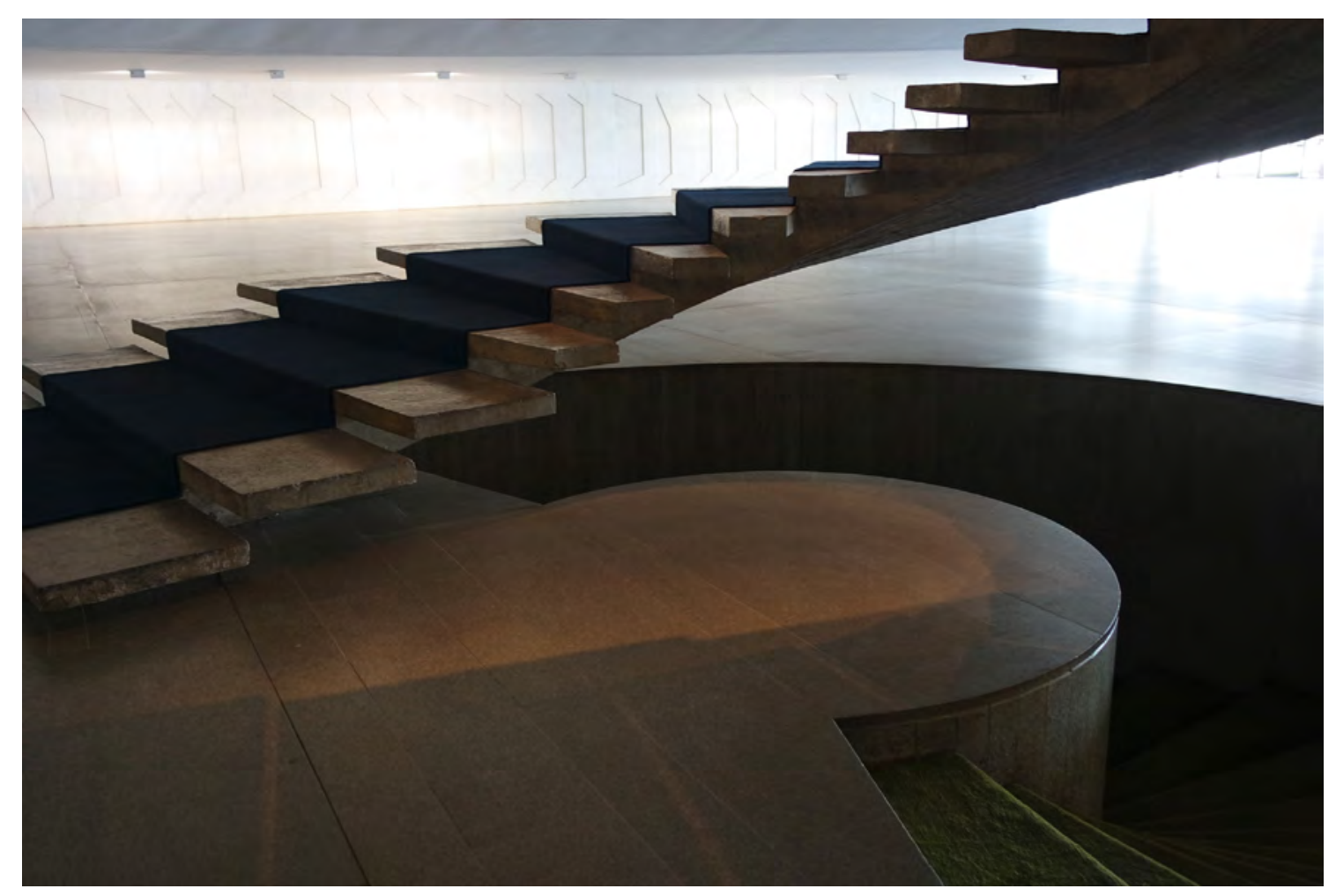

Figura 120: Escada Helicoidal. Fonte: Karen Matsuda, 2019.

O subsolo é iluminado artificialmente. Sua unificação espacial ocorre pela cor verde do carpete do piso, das paredes e do couro das poltronas que é acentuado pelo revestimento das paredes em madeira pau-ferro, o que o torna o ambiente mais silencioso e intimista do palácio. A escada helicoidal leva ao térreo. 


\section{CONSIDERAÇÕES FINAIS}


A arquitetura por si só já é um documento histórico. Observar onde o edifício está localizado, os materiais empregados e a forma encontrada para criar o espaço arquitetônico já possibilita questionamentos e respostas sobre como a construção foi concebida. O resultado final deste processo - o edifício - é vestígio de um procedimento e, em muitas vezes, documento material público de um passado. Ao mesmo tempo, por sua materialidade e dimensões, a arquitetura se faz presente na paisagem e na memória social.

O Ministério das Relações Exteriores é responsável pelo estabelecimento de relações com as demais nações, representando os interesses do Brasil. O Palácio Itamaraty é o edifício representativo, onde as recepções e eventos diplomáticos ocorrem. Até 1970, o ministério funcionou no Rio de Janeiro, mais precisamente no Palácio Itamaraty, localizado na antiga Rua Larga. O palacete foi moradia do Conde do Itamarati e, posteriormente, sede do governo republicano (1889-1898) e do Ministério das Relações Exteriores (1899-1970).

O projeto da sede do Ministério das Relações Exteriores em Brasília começa a ser pensado em 1959, a partir da construção da nova capital. Mas é em 1964, com o então Conselheiro Wladimir Murtinho como Chefe da Comissão de Transferência e o contrato com a Construtora Pederneiras que o projeto começa a ganhar os contornos para sua execução. O processo do projeto foi desenvolvido em uma conjuntura de instabilidade e de disputas políticas do governo brasileiro durante os anos 1960.

A pesquisa de fontes primárias foi fundamental para compreender as inquietações e as soluções da equipe de projeto de modo a tornar a análise mais profunda sobre o objeto arquitetônico e a levantar a complexidade em que se encontra o fazer arquitetura. Devido às diferentes escalas do objeto estudado, a leitura associada dos documentos potencializou as complexidades em que a produção da arquitetura está inserida, alargando a compreensão sobre a elaboração do objeto de estudo. Tais como as fontes encontradas, os arquivos visitados possuem naturezas diversas, pluralidade de vocações. O Setor de Arquitetura do Ministério das Relações Exteriores (SARQ) cuida dos edifícios do Ministério das Relações Exteriores, tanto os que estão localizados em Brasília, como das embaixadas. Não é sua função primeira ser um arquivo. Evidentemente, também funciona como arquivo. Os arquivos privados de Bernardo Figueiredo, Milton Ramos e Norberto Nicola são de responsabilidade familiar e não são arquivos institucionais, mas preservam materiais que contam muito sobre a memória e atuação desses profissionais. O Instituto Moreira Salles, o Instituto de Arte Contemporânea, o Arquivo Histórico do Museu de Arte de São Paulo (MASP), o Arquivo Histórico Wanda Svevo da Fundação Bienal de São Paulo, o Arquivo da Câmara dos Deputados e o Arquivo do Senado Federal são arquivos e, 
deste modo, o levantamento dos documentos é facilitado, pois o material já está catalogado e muitos estão digitalizados. O Instituto do Patrimônio Histórico e Artístico Nacional - Distrito Federal (IPHAN-DF) protege os bens culturais do Distrito Federal e realizou o levantamento de bens móveis e imóveis da capital, tornando possível a verificação de informações sobre obras de arte que não foram encontradas no palácio.

O uso de acervos on-line, como a Hemeroteca Digital da Biblioteca Nacional facilitou a pesquisa do material. As informações encontradas no jornal Correio Braziliense colocam o processo de projeto do Palácio Itamaraty em uma conjuntura social, política e econômica. Aqui, o debate sobre o nome do palácio indica questões sobre continuidade ou ruptura dentro do Ministério das Relações Exteriores a partir da mudança de sede. O edifício também foi visto como importante para a consolidação de Brasília como capital. Além de ser um ministério profundamente ligado à divulgação da produção brasileira no exterior - o que lhe deu autonomia na escolha das peças para o palácio, também era responsável pelo diálogo com as embaixadas, instituições que fortaleceriam a consolidação da nova capital, tanto com capital financeiro, como com capital social.

A análise dos documentos encontrados nos arquivos possibilitou a compreensão de parte do caminho que envolveu a seleção das obras pertencentes ao palácio, indicando as temporalidades envolvidas no projeto durante a obra e também após a ocupação do edifício. Tal olhar só foi possível pelo encontro destes documentos. Por fim, a divulgação destes arquivos torna pública a existência deste material e é uma forma de fazer plural o debate sobre o Palácio Itamaraty, proporcionado ao leitor uma variedade de interpretações. E, longe de se desejar a busca pela totalidade de documentos sobre o palácio, buscou-se vestígios desse processo.

Diferente das antigas sedes governamentais no Rio de Janeiro, que foram adquiridas pelo Estado e, portanto, seus interiores conviviam com as soluções adotadas pelo uso anterior dos palacetes e com incorporações para as novas demandas - um exemplo é o próprio Palácio Itamaraty do Rio de Janeiro que foi residência do Conde do Itamarati e posteriormente foi sede do Ministério das Relações Exteriores. Os palácios em Brasília possibilitaram a criação de espaços governamentais a partir de conceitualização e soluções formais novas, sem readequações, o que tornou tais palácios lugares propícios para experimentações.

No âmbito da produção da arquitetura moderna no Brasil, o Palácio Itamaraty é constituído por uma gramática clássica, com sua planta e arcadas simétricas em Brasília - cidade moderna. No entanto, essa linguagem é tensionada pelo uso do concreto aparente com as marcas das ripas de madeira. $\mathrm{O}$ interior do palácio também foi cuidadosamente pensado para que os espaços acolhessem os rituais do cerimonial diplomático - ora mais aberto, como é no Térreo, ora mais fechado, como é na Sala do Ministro. Para 
isso, obras de arte, mobiliário, tapeçarias e tapetes compõem os ambientes. O olhar para os detalhes foi uma constante tanto no projeto de arquitetura, como durante o trabalho no canteiro.

Na produção de Roberto Burle Marx, o projeto para o palácio mostrouse profícua, tanto com a elaboração do desenho para a tapeçaria Vegetação do Planalto Central, como com os jardins que integram os pavimentos do palácio. No âmbito da produção moveleira no Brasil, o Palácio Itamaraty foi um campo de experimento, pois aparece o desejo de conceber móveis palacianos e modernos, com leveza e nobreza. A seleção das obras de arte, por vezes, partiu do desejo de Oscar Niemeyer, como o caso do Polivolume: Ponto de Encontro, de Mary Vieira; em outras, por escolha do Embaixador Wladimir Murtinho, como Revoada de Pássaros, de Pedro Correia de Araújo. Há nomes ligados à Escola Carioca, como Alfredo Ceschiatti, Alfredo Volpi, Athos Bulcão, Bruno Giorgi e José Pedrosa. Há também nomes ligados ao Ministério das Relações Exteriores, como Luiza Miller, Maria Leontina, Maria Martins, Milton Dacosta e Sônia Ebling, devido, sobretudo, às premiações e aos estudos dos artistas no exterior.

Embora não seja o intuito da dissertação, o levantamento do processo de projeto do palácio durante os anos 1959 e 1970 tornou possível o olhar para as mudanças dos bens móveis no edifício. Há incorporações ou retiradas de obras de arte, tapeçarias, tapetes e mobiliário ao longo dos anos. Por exemplo, no Hall do Subsolo, há os painéis Templo de Oxalá de Rubem Valentim e Grande Relevo Branco de Emanoel Araujo que são escolhas posteriores, a primeira é de 1977, a segunda de 2008. Por ser um palácio em que o caminhar pelos ambientes é parte do programa e também possibilita a apresentação de certa narrativa sobre a produção material no Brasil, entender que os interiores do palácio foram alterados ao longo do tempo coloca como fundamental o levantamento de fontes primárias para a compreensão da concepção e construção desejada à época do projeto para os espaços palacianos. E mais do que isso: mostra o surgimento de novos agentes, novas demandas e novos interesses na construção de um espaço, como se pode observar nas imagens a seguir. Dito de outro modo, apresenta a dinâmica espacial a partir do tempo. Aliás, a questão que permanece é o quanto os ambientes internos foram finalizados, lembremos que o Embaixador Wladimir Murtinho deixa o cargo de Presidente da Comissão de Transferência meses antes da inauguração do Palácio Itamaraty. Lembremos também da urgência dada à transferência de sede do Ministério das Relações Exteriores para a consolidação da nova capital. 


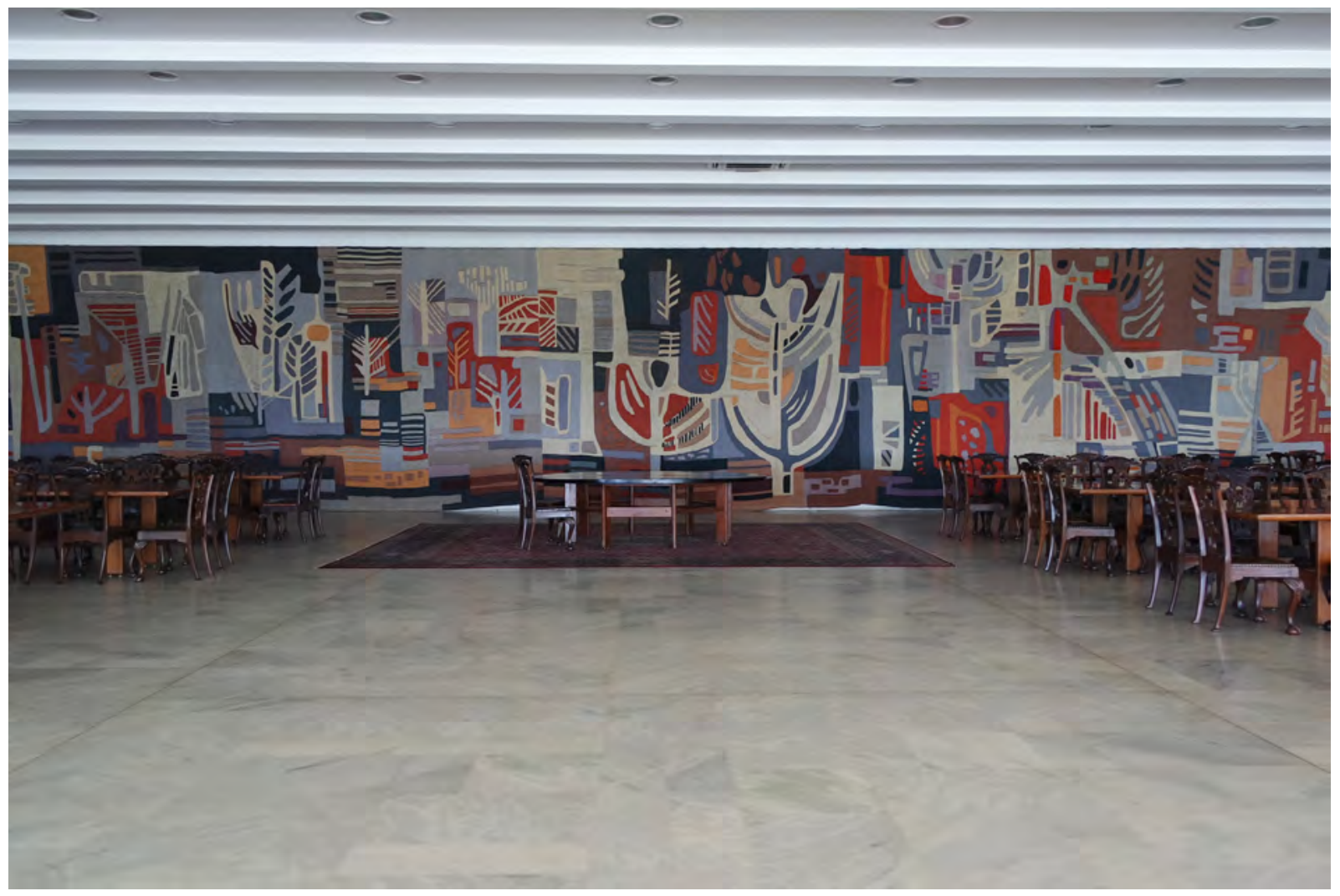

Figura 121: Atual Sala Brasília, antigo Salão de Banquetes. Fonte: Karen Matsuda, 2019. 
5. CONSIDERAÇÕES FINAIS / 193

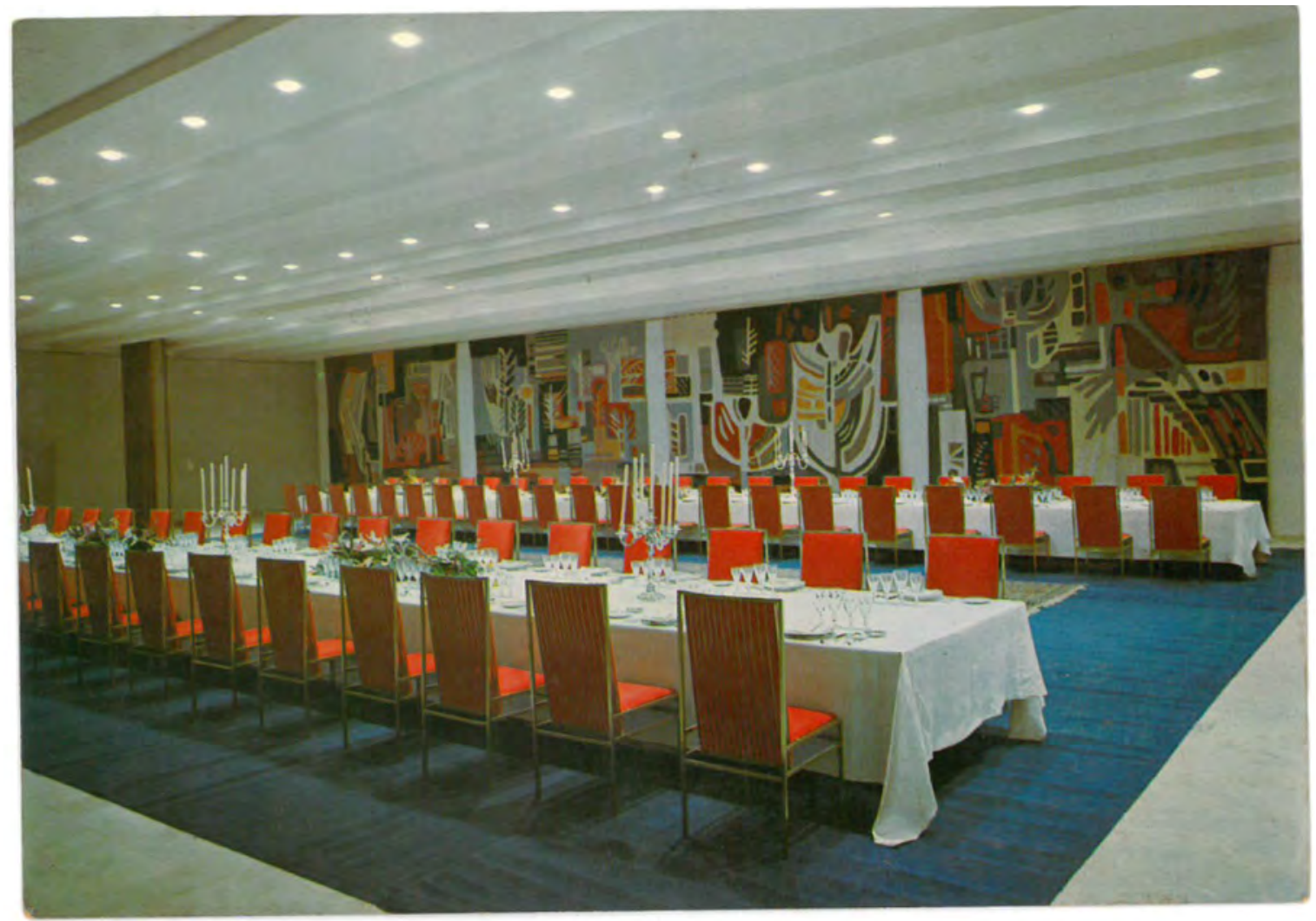

Figura 122: Antigo Salão de Banquetes, atual Sala Brasília, autor desconhecido, datação não identificada. Fonte: Acervo Antonio Carlos Suster Abdalla. 


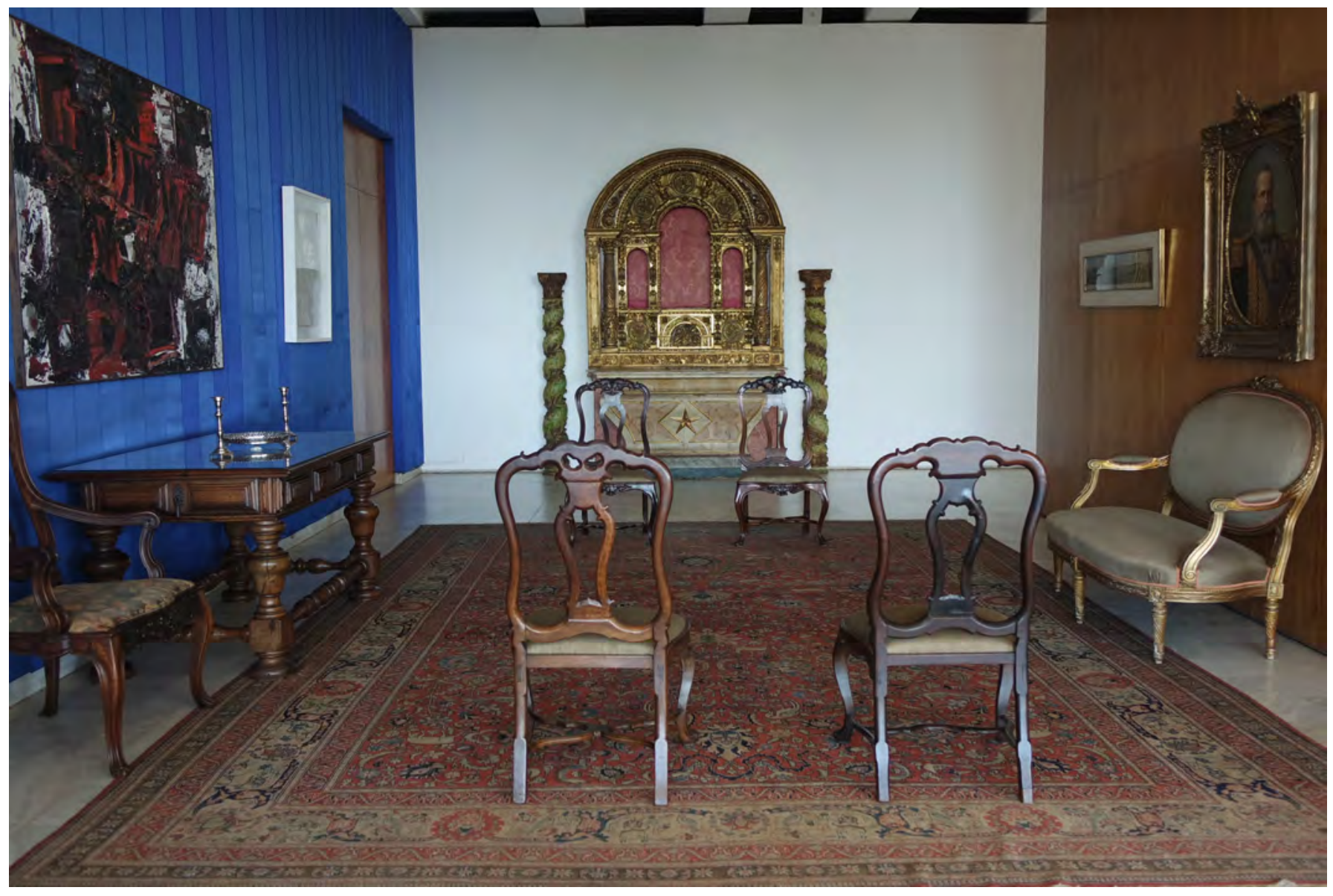

Figura 123: Sala de Estar - Terceiro Pavimento.

Fonte: Karen Matsuda, 2019. 
5. CONSIDERAÇÕES FINAIS / 195

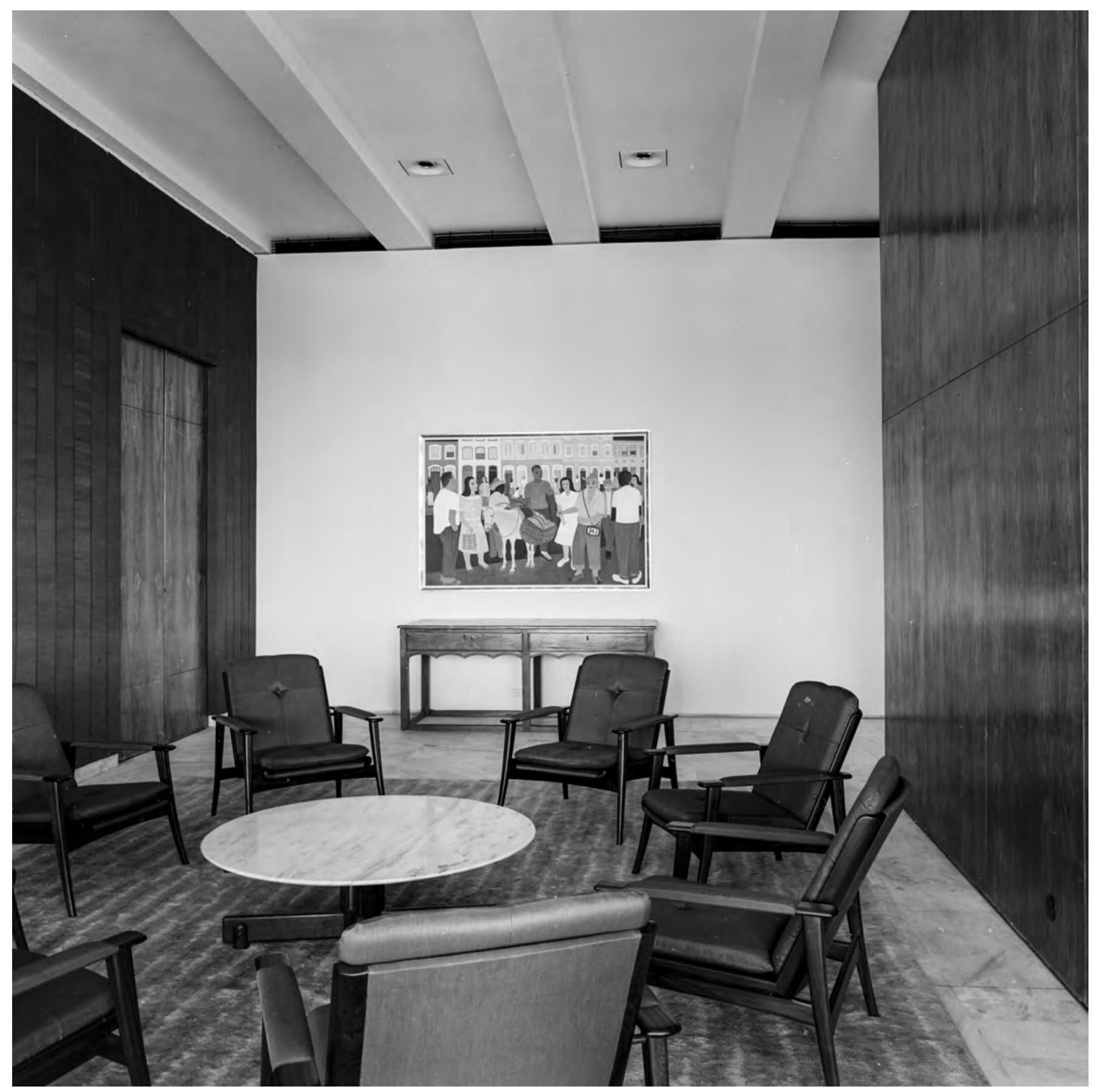

Figura 124: Sala de Estar - Terceiro Pavimento, Marcel Gautherot, c.a. 1968.

Fonte: Instituto Moreira Salles. 


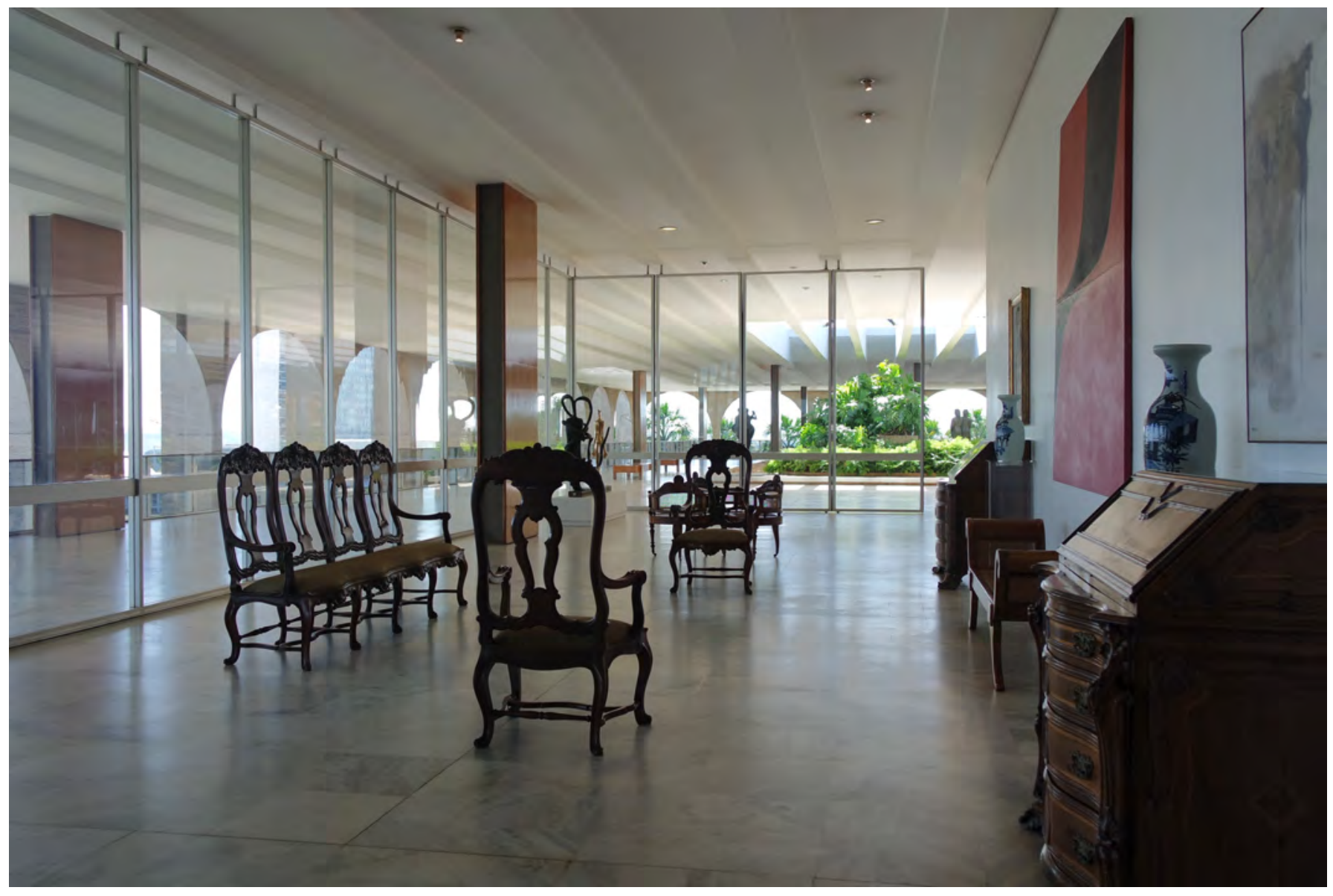

Figura 125: Atual Sala Duas Épocas, Antigo Pequeno Salão.

Fonte: Karen Matsuda, 2019. 
5. CONSIDERAÇÕES FINAIS / 197

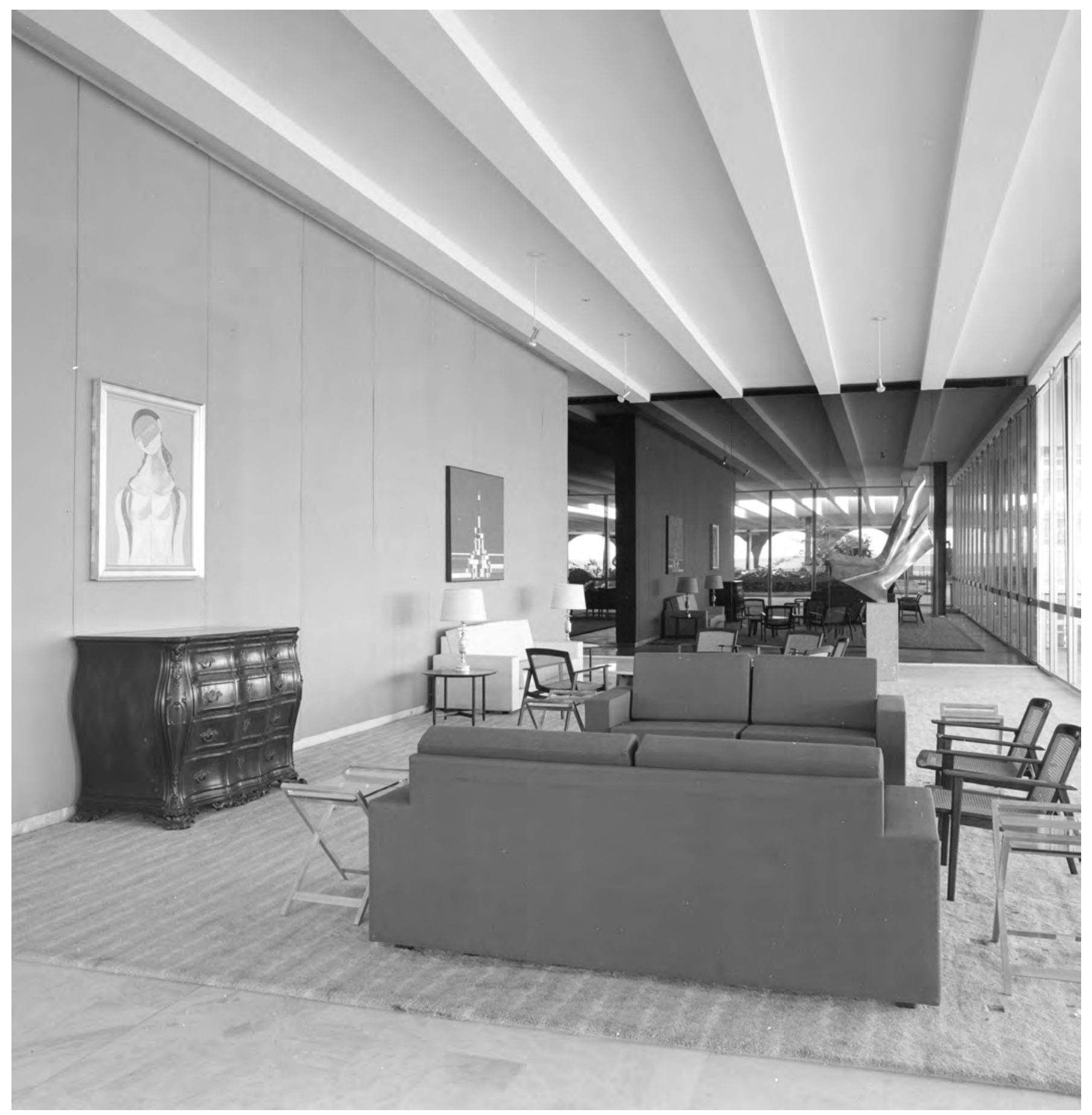

Figura 126: Antigo Pequeno Salão, Atual Sala Duas Épocas, Marcel Gautherot, c.a. 1968. Fonte: Instituto Moreira Salles. 


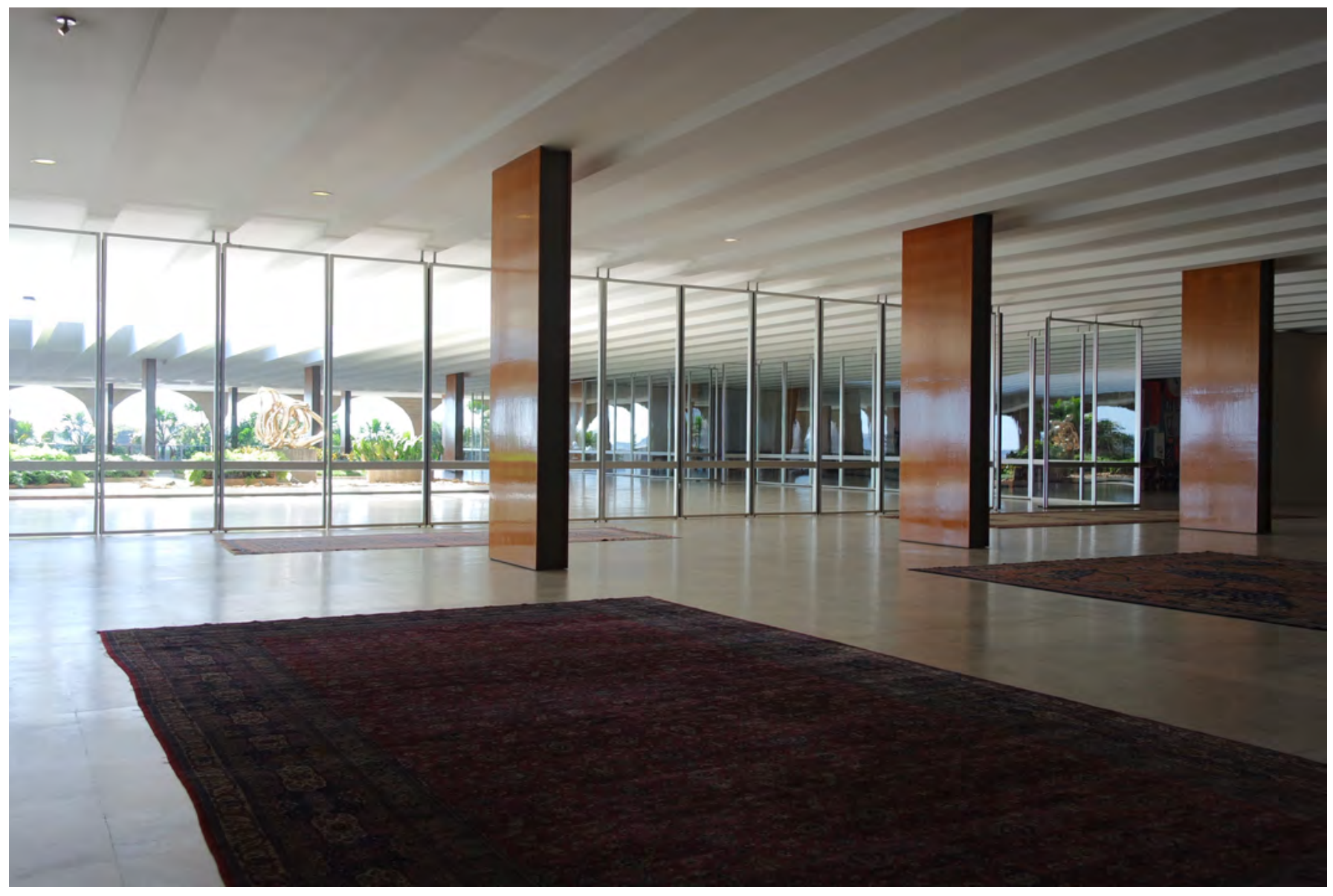

Figura 127: Atual Sala Portinari, Antigo Salão de Baile. Fonte: Karen Matsuda, 2019. 
5. CONSIDERAÇÕES FINAIS / 199

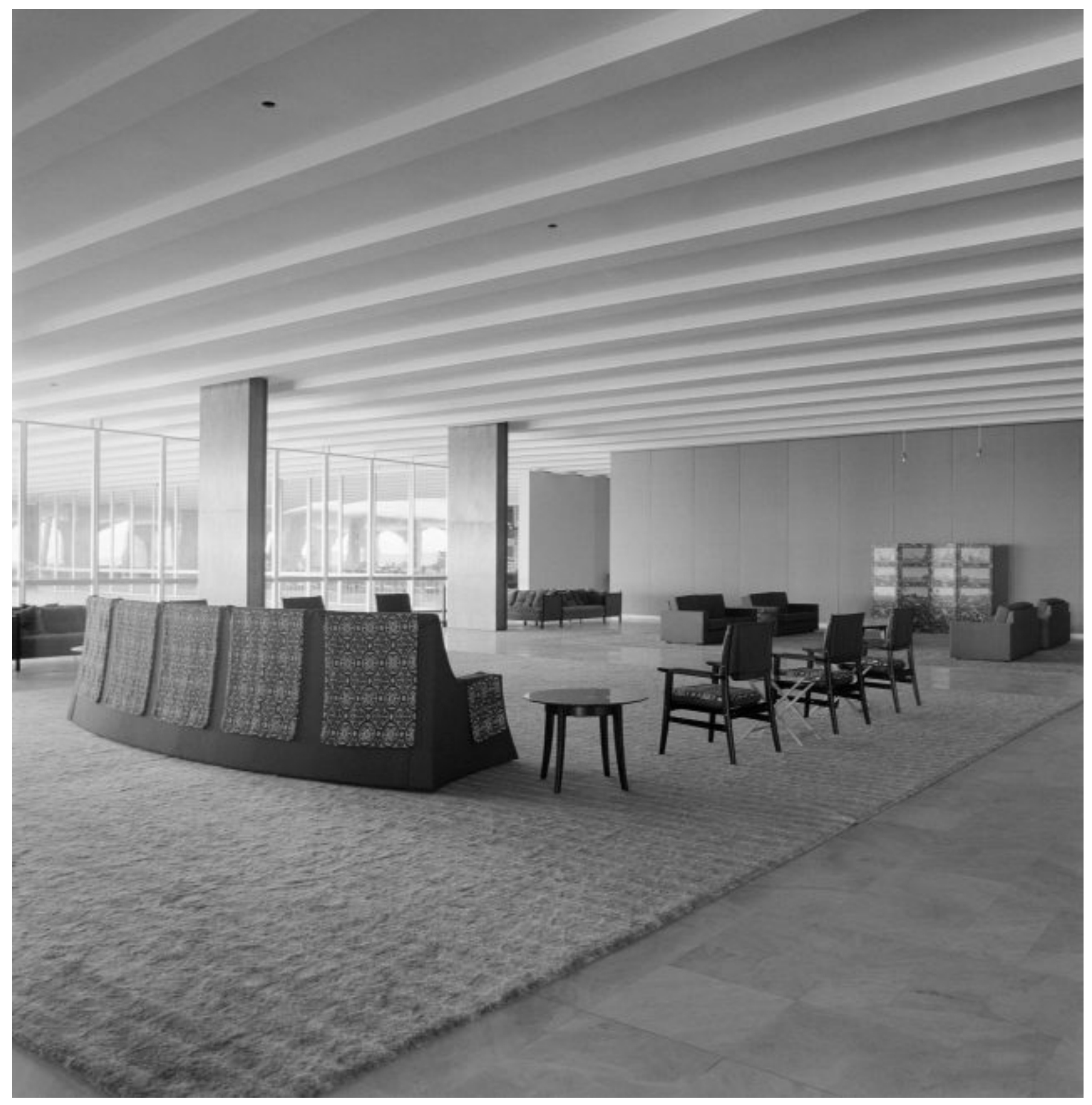

Figura 128: Antigo Salão de Baile, Atual Sala Portinari, Marcel Gautherot, c.a. 1968. Fonte: Instituto Moreira Salles. 


\section{REFERÊNCIAS}

\section{BIBLIOGRÁFICAS}

AMADO, André. Por dentro do Itamaraty: impressões de um diplomata. Brasília: FUNAG, 2013.

ARANTES, Otília. "Esquema de Lúcio Costa” In: Um modo de ser moderno. Lucio Costa e a crítica contemporânea. CONDURU, Roberto; NOBRE, Ana Luiza; KAMITA, João Masao; LEONÍDIO, Otavio (Orgs.) São Paulo, Cosac Naify, 2004.

ARGAN, Giulio Carlo. Arte Moderna. São Paulo: Companhia das Letras, 1993.

ARGAN, Giulio Carlo. Projeto e Destino. São Paulo: Ática, 2001.

BANHAM, Reyner. Teoria e projeto na primeira era da máquina. São Paulo: Editora Perspectiva, 1979.

BARROS, Luiz Antonio Recamán de. Oscar Niemeyer: forma arquitetônica e cidade no Brasil moderno. Tese de Doutorado, São Paulo, FFLCHUSP, 2002.

BARROS, Luiz Antonio Recamán de. Por uma arquitetura, brasileira. Dissertação de Mestrado. FFLCHUSP, 1995.

BENSE, Max. Pequena estética: inteligência brasileira. São Paulo: Editora Perspectiva, 2009.

BOTEY, Josep Maria. Oscar Niemeyer: works and projects. Barcelona: Gustavo Gili, 1996.

BRITO, Ronaldo. Experiência crítica. São Paulo: Cosac Naify, 2006.

BRITO, Ronaldo. "Fluida modernidade" In: Um modo de ser moderno. Lucio Costa e a crítica contemporânea. CONDURU, Roberto; NOBRE, Ana Luiza; KAMITA, João Masao; LEONÍDIO, Otavio (Orgs.) São Paulo, Cosac Naify, 2004.

BRUAND, Yves. Arquitetura Contemporânea no Brasil. São Paulo: Perspectiva, 1999.

CASTRO, Eduardo Viveiros de. A inconstância da alma selvagem. São Paulo: Cosac Naify. 2002.

CASTRO, Flávio Mendes de Oliveira. Dois séculos de história da organização do Itamaraty (1808-2008). Brasília: Fundação Alexandre de Gusmão, 2009.

CALS, Soraia. Tenreiro. Rio de Janeiro: Bolsa de Arte do Rio de Janeiro, 1998.

COLQUHOUN, Allan. Modernidade e Tradição Clássica: ensaios sobre arquitetura. São Paulo: Cosac Naify, 2004.

CHARTIER, Roger. O mundo como representação. In: Estudos Avançados. 5 (11): 173 - 191, 1991.

CLAY, J. Brasilia continue: L'architecte Niemeyer vient d'achever un nouveau palais. Connaissance des Arts, Paris, 1968. 
CONDURU, Roberto; NOBRE, Ana Luiza; KAMITA, João Masao; LEONÍDIO, Otavio (orgs.). Um modo de ser moderno. Lucio Costa e a crítica contemporânea. Coleção Face Norte, volume 7. São Paulo, Cosac Naify, 2004.

CÓRDOBA, Paola. Levantamento Fotogramétrico de Monumentos Arquitetônicos. Estudo de Caso Palácio Itamaraty - Brasília, DF. Dissertação de Mestrado em Estruturas e Construção Civil, Publicação E.DM-016A/12, Departamento de Engenharia Civil e Ambiental, Universidade de Brasília, Brasília, DF. 2012.

CURTIS, William J. R. Arquitetura moderna desde 190o. Porto Alegre: Bookman, 2008.

ELIAS, Norbert. A Sociedade de Corte. Lisboa: Editorial Estampa, 1987.

ESPADA, Heloisa. Monumentalidade e sombra: a representação do centro cívico de Brasília por Marcel Gautherot. Tese de doutorado. ECA-USP. 2011.

FERNANDES, Fernanda. Síntese das Artes e Cultura Urbana: Arte, Arquitetura e Cidade em São Paulo, 1950. Tese de Livre-Docência: FAUUSP, 2014.

FICHER, Sylvia. Brasílias. In: Revista Projeto n. 242, abril/2000. p. 48-52.

GINZBURG, Carlo. Mitos, Emblemas, Sinais: Morfologia e História. São Paulo: Companhia das Letras, 2009.

GOODWIN, Philip L. Brazil Builds: architecture new and old, 1652 - 1942. Photographs by G. E. Kidder Smith. New York: Museum of Modern Art, 1943.

GORELIK, Adrián. Das vanguardas a Brasília: cultura urbana e arquitetura na América Latina. Belo Horizonte: Editora UFMG, 2005.

GUERRA, Abilio. Modernidade e Tradição. Tese de Doutorado. São Paulo: Unicamp, 2002.

(org.). Textos fundamentais sobre história da arquitetura moderna brasileira (vol.o1). São Paulo: Romano Guerra, 2010.

(org.). Textos fundamentais sobre história da arquitetura moderna brasileira (vol.o2). São Paulo: Romano Guerra, 2010.

HUE, Jorge. Jorge Hue. Rio de Janeiro: Contra Capa / Artepadilha, 2010.

FRAMPTON, Kenneth. História crítica da arquitetura moderna. São Paulo: Martins Fontes, 1997.

KAMITA, João Masao. Espaço moderno e país novo: arquitetura moderna no Rio de Janeiro. Universidade de São Paulo, São Paulo, 1999.

KATINSKY, Júlio Roberto. Brasília em três tempos. Rio de Janeiro: Revan, 1991.

KATINSKY, Júlio Roberto. Técnica e Arte na obra de Oscar Niemeyer. São Paulo: produção acadêmica FAUUSP, 1996.

LIRA, José. O visível e o invisível na arquitetura brasileira. São Paulo: DBA, 2017. 
LUIGI, Gilbert. Oscar Niemeyer une esthétique de la fluidité. Marseille: Editions Parenthèses. 1987.

MAGALHÃES, Carlos Henrique. Milton Ramos $e$ o rigor da forma construtiva. Arquitextos, São Paulo, ano 10, n. 110.01, Vitruvius, jul. 2009.

MARTINS, Carlos Alberto Ferreira. Arquitetura e Estado no Brasil: elementos para uma investigação sobre a constituição do discurso moderno no Brasil: a obra de Lúcio Costa 1924-1952. Universidade de São Paulo, São Paulo, 1988.

MAURÍCIO, Jaime. Palácio Rio Branco, Brasília. Habitat, n. 52, 1959.

MENESES, Ulpiano T. Bezerra de. A cultura material no estudo das sociedades antigas. Revista de História, São Paulo, n.115, p. 103-117, 1985.

MENESES, Ulpiano T. Bezerra de. Fontes visuais, cultura visual, História visual. Balanço provisório, propostas cautelares. Revista Brasileira de História. São Paulo, v. 23, n.45, p. 11-36, 2003.

MINDLIN, Henrique E. Arquitetura moderna no Brasil. 2a ed. Trad. Paulo Pedreira. Rio de Janeiro. Aeroplano Editora / IPHAN, 2000. (1 a edição, 1956).

MORAES, Dijon de. Análise do design brasileiro: entre mímese e mestiçagem. São Paulo: Edgard Blucher, 2006.

MORELLI, Ana. Correio Braziliense: 40 anos - do pioneirismo à consolidação. Dissertação de Mestrado, Brasília: Faculdade de Comunicação - UNB, 2002.

NAPOLITANO, Marcos. 1964: História do Regime Militar Brasileiro. São Paulo: Contexto, 2014.

NIEMEYER, Oscar. As Curvas do Tempo - Memórias. Editora Revan, 2000, $7^{\mathrm{a}}$ edição, Rio de Janeiro, 2000.

NIEMEYER, Oscar. "Depoimento" In: Revista Módulo n. 09. Rio de Janeiro, fevereiro de 1958. p. 03-06.

NIEMEYER, Oscar. Minha experiência em Brasília. Rio de Janeiro: Avenir, 1961.

NIEMEYER, Oscar. Minha arquitetura. Rio de Janeiro: Revan, 2000.

Palácio Itamaraty Brasília: Brasília, Rio de Janeiro. São Paulo: Banco Safra, 2002.

OSCAR Niemeyer. Milão: editora Arnoldo Mondadori. 1975.

PAPADAKI, Stamo. The work of Oscar Niemeyer. New York: Rheinhold Publishing, 1950.

PANOFSKY, Erwin. Significado nas artes visuais. São Paulo: Perspectiva, 2011.

PENNA, J. O. D. M. Quando mudam as capitais. Brasília: Senado Federal, Conselho Editorial, 2002.

PEREC, Georges. Pensar/Clasificar. Barcelona: Gedisa, 1986.

PERRONE-MOISÉS, Leyla. Vira e mexe, nacionalismo: paradoxos do nacionalismo literário. São Paulo: Companhia das Letras, 2007.

PHILIPPOU, Styliane. Oscar Niemeyer: Curves of Irreverence. Yale University Press. 2008. 
PRADO, Maria Lígia Coelho; VILLAÇA, Mariana (orgs.). História das Américas: fontes e abordagens historiográficas. São Paulo: Humanitas: CAPES, 2015.

QUEIROZ, Rodrigo. Oscar Niemeyer e Le Corbusier: Encontros. Tese de Doutorado. FAU-USP. 2007.

RICUPERO, Rubens. A diplomacia na construção do Brasil (1750-2016). Rio de Janeiro: Versal, 2017.

ROSSETTI, Eduardo Pierrotti. Arquitetura em transe. Lucio Costa, Oscar Niemeyer, Vilanova Artigas e Lina Bo Bardi: nexos da arquitetura brasileira pós-Brasília (1960-85). Tese de Doutorado. São Paulo: FAU-USP, 2007.

ROSSETTI, Eduardo Pierrotti. A arquitetura do Palácio Itamaraty (1959-170). Arquitextos, São Paulo, ano 10, Vitruvius, 2009.

ROSSETTI, Eduardo Pierrotti. Palácio do Itamaraty: questões de história, projeto e documentação (1959-70). Arquitextos, São Paulo, ano 09, Vitruvius, 2009.

ROSSETTI, Eduardo Pierrotti; RAMOS, Graça; SELIGMAN, Graça. Palácio Itamaraty: a arquitetura da diplomacia. Brasília: ITS, 2017.

SANTOS, Maria Cecilia Loschiavo dos. Móvel Moderno no Brasil. São Paulo: Olhares, 2015.

SANTOS, Maria Cecilia Loschiavo dos. SAKURAI, Tatiana. Móvel Moderno Brasileiro. São Paulo: Olhares, 2017.

SARLO, Beatriz. Viagem ao futuro do passado. Revista Piauí, n. 70, julho 2012.

SCHWARCZ, Lilia Moritz; STARLING, Heloisa Murgel. Brasil: um biografia. São Paulo: Companhia das Letras, 2018.

SEGRE, Roberto, Viana \& Mosley (Org.). Tributo a Niemeyer. Rio de Janeiro, 2009.

TELLES, Sophia da Silva. Arquitetura moderna no Brasil: o desenho da superfície. Dissertação de Mestrado, São Paulo, FFLCHUSP, 1988.

TITAN, Samuel; BURGI, Sergio (orgs.) Marcel Gautherot: Brasília. Rio de Janeiro: IMS.

UNDERWOOD, David. Oscar Niemeyer e a arquitetura de formas livres no Brasil. São Paulo: Cosac Naify, 2002.

XAVIER, Alberto; KATINSKY, Julio Roberto (Orgs.). Brasília: Antologia Crítica. Face Norte, volume 14. São Paulo: Cosac Naify, 2012.

VALLE, Marco Antonio Alves do. Desenvolvimento da forma e procedimentos de projeto na arquitetura de Oscar Niemeyer (1935-1998). Tese de Doutorado. São Paulo, FAUUSP. 2000.

WAGNER, Roy. A invenção da cultura. São Paulo: Cosac Naify. 2012.

WÖLFFLIN, Heinrich. Conceitos fundamentais da história da arte: o problema da evolução dos estilos na arte mais recente. São Paulo: Martins Fontes, 1989.

ZEVI, Bruno. Saber ver a arquitetura. São Paulo: Martins Fontes, 2000. 


\section{PUBLICAÇÕES PERIÓDICAS CONSULTADAS}

Acrópole n. 375/376, 1970.

Habitat n. 52, 1959.

L'Architecture d'Aujourd'hui n. 90, 1960.

L'Architecture d'Aujourd'hui n. 171, 1977.

L'oeil n. 184, 1970.

Connaissance des Arts, 1968.

\section{PERIÓDICOS CONSULTADOS NA HEMEROTECA DIGITAL DA BIBLIOTECA NACIONAL}

A sala de visita do Brasil. Jornal Correio Braziliense, Brasília, 20 de abril de 1966, p. 3

A realidade de Brasília. Jornal Correio Braziliense, Brasília, 24 de agosto de 1962, p. 4.

A importância do Itamarati. Jornal Correio Braziliense, Brasília, 10 de março de 1966, p. 4.

Autoridades empenham-se na transferência do Itamarati para o DF. Jornal Correio Braziliense, Brasília, 18 de junho de 1964, p. 6.

ALMEIDA, Duílio de. Itamarati, o mais fabuloso palácio moderno do mundo. Jornal Correio Braziliense, Brasília, 07 de junho de 1967, p. 9.

ALMEIDA, Duílio de. O que ver no Itamarati, Jornal Correio Braziliense, Brasília, 19 de abril de 1969, Caderno 2, p. 13.

AULER, Hugo. Atelier. Jornal Correio Braziliense, Brasília, o9 de setembro de 1969. p. 10.

AULER, Hugo. Atelier. Jornal Correio Braziliense, Brasília, 11 de dezembro de 1968. p. 10.

Capital. Jornal Correio Braziliense, Brasília, 20 de maio de 1966, p. 1.

Correio Diplomático. Jornal Correio Braziliense, Brasília, o5 de abril de 1970, p. 5. Correio Diplomático. Jornal Correio Braziliense, Brasília, 11 de abril de 1970, p. 5. CUNHA, Ari. Visto, Lido, Ouvido. Jornal Correio Braziliense, Brasília, o9 de março de 1967, p. 3.

CUNHA, Ari. Visto, lido e ouvido. Jornal Correio Braziliense, Brasília, 17 de junho de 1964, p. 3.

Itamarati: uma decisão. Jornal Correio Braziliense, Brasília, 30 de janeiro de 1966, p. 4.

Itamaraty tem nova escultura. Jornal Correio Braziliense, Brasília, 17 de abril de 1970. p. 3 .

JEAN, Yvonne. Esquina de Brasília: Palácio dos arcos ou Itamarati de Brasília ?. Jornal Correio Braziliense, Brasília, 21 de abril 1966, p. 2. 
JEAN, Yvonne. Esquina de Brasília. Jornal Correio Braziliense, Brasília, o5 de abril de 1970, p. 2.

KATUCHA. Sociais de Brasília. Jornal Correio Braziliense, Brasília, 26 de abril de 1966, p. 9.

O governo e a notícia. "Bienal”. Jornal Correio Braziliense, Brasília, 11 de fevereiro de 1966, p. 3 .

MAM expõe hoje painel com estranha máquina que Darel fez para Brasília. O Globo, Rio de Janeiro, 12 de março de 1969.

MAURÍCIO, Jayme. "Artista brasileira conhecida em Paris antes do Brasil”. Jornal Correio da Manhã, Rio de Janeiro, o3 de maio de 1962.

MENDES, Manuel. Nome Itamarati é símbolo para a nossa diplomacia. Jornal Correio Braziliense, Brasília, 13 de setembro de 1960, p. 1.

MENDES, Manuel. Correio Diplomático. Nome para o prédio do MRE em Brasília. Jornal Correio Braziliense, Brasília, 9 de janeiro de 1966, p. 9.

Meteoro chega da Itália para ornamentar futura sede do Itamarati em Brasília. Jornal Correio Braziliense, Brasília, 23 de dezembro de 1966. p. 1.

Mudança do Itamarati está sendo ultimada. Jornal Correio Braziliense, Brasília, o6 de fevereiro de 1962, p. 1.

O Palácio dos Arcos pronto em janeiro. Jornal Correio Braziliense, Brasília, 20 de janeiro de 1966, p. 1.

O Itamarati já tem maquete. Jornal Correio Braziliense, Brasília, 25 de março de 1964. p. 1.

Palácio do Itamarati deverá estar funcionando em Brasília até 1965. Jornal Correio Braziliense, Brasília, 20 de maio de 1964, p. 8.

Presidente manda acelerar o andamento das obras no DF. Jornal Correio Braziliense, Brasília, 14 de maio de 1964, p. 8.

Ponto de encontro. Correio Diplomático. Jornal Correio Braziliense, Brasília, 10 de abril de 1970. p. 5 .

Salões da Chancelaria prontos até o dia 15. Jornal Correio Braziliense, Brasília, 25 de fevereiro de 1967, p. 1.

Será assinado amanhã convênio para construção da quadra de apartamentos do Itamarati em Brasília: transferência. Jornal Correio Braziliense, Brasília, o2 de julho de 1964, p. 6.

SIMÕES, Carlos. A cidade dos meus sonhos (VIII). Mexeram no plano residencial. Jornal Correio Braziliense, Brasília, 16 de abril de 1970. p. 26.

Vasco diz que Palácio dos Arcos dará maior projeção a Brasília. Jornal Correio Braziliense, Brasília, 9 de dezembro de 1965, p. 1.

Violento incêndio destrói três pavimentos do Bloco 11 da Esplanada dos Ministérios. Jornal Correio Braziliense, Brasília, 15 de agosto de 1964, p. 8. 


\section{FONTES ESCRITAS CITADAS}

PUBLICAÇÕES

DOURADO, Guilherme Mazza. Folhas em movimento - cartas de Burle Marx. São Paulo: FAPESP - RELATÓRIO DE PESQUISA EM PÓS-DOUTORADO FAU-USP, 2014.

DOURADO, Guilherme Mazza. Folhas de toda a parte - cartas para Burle Marx. São Paulo: FAPESP - RELATÓRIO DE PESQUISA EM PÓS-DOUTORADO FAUUSP, 2014.

MENDES, Manuel. O cerrado de casaca. Brasília: Thesaurus, 1995.

MURTINHO, Wladimir do Amaral. Depoimento - Programa de história oral. Brasília: Arquivo Público do Distrito Federal, 1990.

\section{ACERVO BERNARDO FIGUEIREDO}

Textos avulsos sobre o mobiliário

\section{ACERVO ON-LINE CASA LÚCIO COSTA}

Texto manuscritos de Lúcio Costa nomeado como: "O Itamaraty, para mim...”

\section{ARQUIVO DA CÂMARA DOS DEPUTADOS}

Relatório de Despesas - Resposta ao Requerimento de Informações $n^{0} 4308$, de 1968, pelo Embaixador Wladimir Murtinho

\section{ARQUIVO DO SENADO FEDERAL}

Projeto de Lei do Senado n. 10, de 1967, Senador Vasconcelos Torres

Requerimento $n^{\circ} 431$, de 1967, Senador Vasconcelos Torres

ARQUIVO HISTÓRICO DO MUSEU DE ARTE DE SÃO PAULO (MASP)

Pasta de Referência: Pedro Correia de Araújo: Carta endereçada para Pietro Maria Bardi

\section{ARQUIVO HISTÓRICO WANDA SVEVO DA FUNDAÇÃO BIENAL DE SÃO PAULO}

Convênio entre o Ministério das Relações Exteriores e a Fundação Bienal de São Paulo

Catálogo da MCMLXX Bienal de Veneza XXXV Brasil Burle Marx Mary Vieira (1970) 
6. REFERÊNCIAS / 207

Catálogo IX Bienal de São Paulo (1967)

Ata do júri de aquisição - IX Bienal

CENTRO DE HISTÓRIA E DOCUMENTAÇÃO DIPLOMÁTICA

Relatórios do Ministério das Relações Exteriores

IPHAN-DF

Inventário dos bens móveis e integrados INBMI - VOLUME I

Inventário dos bens móveis e integrados INBMI - VOLUME II

Inventário dos bens móveis e integrados INBMI - VOLUME III

INSTITUTO DE ARTE CONTEMPORÂNEA (IAC)

Fundo Sergio Camargo: cartas de Sergio Camargo (documento 1831)

SETOR DE ARQUITETURA DO MINISTÉRIO DAS RELAÇÕES EXTERIORES (SARQ MRE)

Memorial Descritivo da Construtora Pederneiras (1964)

Prédio de Representação - Distribuição sugerida

Diário de obra volume VI

\section{IMAGENS CITADAS}

\section{ACERVO ANTONIO CARLOS SUSTER ABDALLA}

Fotografia do Antigo Salão de Banquetes, atual Sala Brasília, sem autoria, datação não identificada.

\section{ACERVO ARQUITETO MR}

Fotografia da Maquete do Palácio Itamaraty, Milton Ramos, datação não identificada.

Fotografia do Palácio Itamaraty, Milton Ramos, datação não identificada.

Fotografia do Palácio Itamaraty, Milton Ramos, datação não identificada.

Croquis de Oscar Niemeyer entregues à Milton Ramos, datação não identificada.

Fotografia da Escada helicoidal, Milton Ramos, datação não identificada. 
Fotografia da Escada helicoidal, Milton Ramos, datação não identificada.

Entrevista de Milton Ramos no Instituto de Arquitetos do Brasil (IAB-DF), em 1966.

\section{ACERVO BERNARDO FIGUEIREDO}

Fotografia da Cadeira Arcos, Bernardo Figueiredo, datação não identificada.

Fotografia do Terceiro Pavimento, Bernardo Figueiredo, datação não identificada.

Fotografia do Terceiro Pavimento, Bernardo Figueiredo, datação não identificada.

Fotografia da Sala Bahia, Bernardo Figueiredo, datação não identificada.

\section{ACERVO DO MUSEU HISTÓRICO E DIPLOMÁTICO}

Planta do Segundo Pavimento do Palácio Itamaraty, no Rio de Janeiro, datação não identificada.

\section{ACERVO ITAÚ CULTURAL}

Cartão modelo da tapeçaria Vegetação do Planalto Central, Roberto Burle Marx, 1960.

\section{ACERVO ON-LINE CASA LÚCIO COSTA}

Desenho do Plano Piloto, Lúcio Costa.

\section{FOTOGRAFIAS ATUAIS POR KAREN MATSUDA}

Palácio Itamaraty, Rio de Janeiro.

Fotografia do pilar.

Fotografia do pilar.

Palácio Itamaraty, fotografia tirada às 8h46, em janeiro de 2019.

Vista da escada helicoidal.

Salão Nobre, Palácio Itamaraty, Rio de Janeiro.

Segundo Andar, 2019.

Salão de Baile, Palácio Itamaraty, Rio de Janeiro.

Auditório

Escada Helicoidal.

Salão de Honra, Palácio Itamaraty, Rio de Janeiro.

Varanda, Palácio Itamaraty, Rio de Janeiro.

Parlatório. 
6. REFERÊNCIAS / 209

Atual Sala Brasília, antigo Salão de Banquetes.

Hall - Terceiro Pavimento.

Atual Sala Duas Épocas, Antigo Pequeno Salão.

Atual Sala Portinari, Antigo Salão de Baile.

\section{INSTITUTO DE ARTE CONTEMPORÂNEA (IAC)}

Fotografia do Muro Escultórico- Sergio Camargo, autor desconhecido, 1972.

Fotografia do Muro Escultórico- Sergio Camargo, autor desconhecido, datação não identificada.

\section{INSTITUTO MOREIRA SALLES}

Fotografia do Palácio Itamaraty, Marcel Gautherot, 1968.

Fotografia do Palácio Itamaraty, Marcel Gautherot, c.a. 1970.

Fotografia do Palácio Itamaraty, Marcel Gautherot, 1968.

Fotografia do Palácio Itamaraty, Marcel Gautherot, 1968.

Fotografia do Palácio Itamaraty, Marcel Gautherot, 1968.

Fotografia do Meteoro, escultura de Bruno Giorgi, Marcel Gautherot, c.a. 1968.

Fotografia do Palácio Itamaraty à noite, Marcel Gautherot, c.a. 1972.

Fotografia do Jardim térreo, Marcel Gautherot, c.a. 1968.

Fotografia do Jardim térreo, Marcel Gautherot, c.a. 1968.

Fotografia do Jardim térreo, Marcel Gautherot, c.a. 1968.

Fotografia do Polivolume: Ponto de Encontro - Mary Vieira, Marcel Gautherot, c.a. 1970.

Fotografia do Polivolume: Ponto de Encontro - Mary Vieira, Marcel Gautherot, c.a. 1970.

Fotografia da Treliça de Athos Bulcão, Marcel Gautherot, 1968.

Fotografia do Afresco de Alfredo Volpi, "Sonho de Dom Bosco", Marcel Gautherot, c.a. 1966.

Fotografia do "Grito do Ipiranga", pintura de Pedro Américo, Marcel Gautherot, c.a. 1968.

Fotografia da Tapeçaria "índios pescadores" e mobiliário desenhado por Sergio Rodrigues, Marcel Gautherot, c.a. 1968.

Fotografia do “Os episódios III”, pintura de Maria Leontina, Marcel Gautherot, c.a. 1968.

Fotografia do Salão dos Embaixadores, Marcel Gautherot, c.a. 1968.

Fotografia do Salão dos Embaixadores, Marcel Gautherot, c.a. 1968. 
Fotografia da Sala de Reuniões do Conselho da Política Exterior, Marcel Gautherot, c.a. 1968.

Fotografia da Escada de acesso ao Terceiro Pavimento, Marcel Gautherot, c.a. 1968.

Fotografia da "Revoada dos pássaros", Pedro Correia de Araújo, Marcel Gautherot, c.a. 1968.

Fotografia da "Revoada dos pássaros", Pedro Correia de Araújo, Marcel Gautherot, c.a. 1968.

Fotografia do “Juramento” - Manabu Mabe, Marcel Gautherot, c.a. 1968.

Fotografia dos Anjos, Marcel Gautherot, c.a. 1968.

Fotografia da Pequena Sala, Marcel Gautherot, c.a. 1968.

Fotografia da Cena de rua, Djanira, Marcel Gautherot, c.a. 1968.

Fotografia de Duas figuras femininas - Alfredo Ceschiatti, Marcel Gautherot, c.a. 1968.

Fotografia do Jardim do Terceiro Pavimento - Roberto Burle Marx, Marcel Gautherot, c.a. 1968.

Fotografia do Canto à noite - Maria Martins, Marcel Gautherot, c.a. 1968.

Fotografia do Hall - Terceiro Pavimento, Marcel Gautherot, c.a. 1968.

Fotografia do Antigo Pequeno Salão, Atual Sala Duas Épocas, Marcel Gautherot, c.a. 1968.

Fotografia do Antigo Salão de Baile, Atual Sala Portinari, Marcel Gautherot, c.a. 1968.

\section{INSTITUTO SERGIO RODRIGUES}

Estudo para o projeto de interiores do Palácio dos Arcos, Sergio Rodrigues, datação não identificada.

SETOR DE ARQUITETURA DO MINISTÉRIO DAS RELAÇÕES EXTERIORES (SARQ MRE) - projetos e croquis

Prédio de Representação - Térreo, datação não identificada.

Prédio de Representação - Perspectiva do Hall, datação não identificada.

Prédio de Representação - $1^{0}$ Andar, datação não identificada.

Prédio de Representação - $2^{\circ}$ Andar, datação não identificada.

Ministério das Relações Exteriores - Corte D-D, 1960.

Planta geral, datação não identificada.

Corte A-A, Novacap, 1960.

Palácio Itamarati Corte e vistas base da pilastra do canto I, II, III, IV, 1963.

Colunas Perimetrais, 1964. 
Detalhe construtivo das pilastras e arcadas, 1965.

Gráfico de insolação para Brasília, 1965.

Paisagismo, Roberto Burle Marx, 1966.

Croquis toldo, Oscar Niemeyer, 1985.

Prédio de Representação - Térreo, datação não identificada.

Planta e Vistas da escada térreo ao $1^{\circ}$ pavimento, 1964.

Planta para estudos de acabamento - Térreo, 1966.

Planta de cotas - jardim do térreo, Roberto Burle Marx, 1966.

Planta de cotas - Lista de plantas, Roberto Burle Marx, 1966.

Escultura detalhes, Roberto Burle Marx, 1966.

Lista de Plantas, Lista de cotas, Roberto Burle Marx, 1966.

Painel de Mármore Branco - Térreo, Athos Bulcão, 1966.

Planta para estudos de acabamento Térreo, 1966.

Apartamento privativo, Sergio Rodrigues, datação não identificada.

Prédio de Representação - $1^{\circ}$ Andar, datação não identificada.

Corte A-A, Novacap, 1960.

Planta para estudos de acabamento $2^{\circ}$ Pavimento, 1965.

Bloco Representativo - $2{ }^{\circ}$ Pavimento, datação não identificada.

Bloco Representativo - $2{ }^{\circ}$ Pavimento, datação não identificada.

Elevação - Gabinete do Ministro, Sergio Rodrigues, datação não identificada.

Gabinete do Ministro, 1969.

Gabinete do Ministro, 1969.

Secretário Geral, 1969.

Prédio de Representação - $2^{\circ}$ Andar, datação não identificada.

Planta para estudo de acabamento, 1966.

Sanitário do Salão de Festas, 1967.

Layout Terceiro Pavimento, datação não identificada.

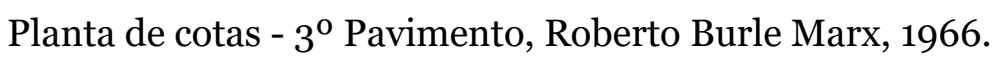

Prédio de Representação - Térreo, datação não identificada.

Planta baixa do plenário, 1963.

Planta de acabamento - subsolo, 1966.

Parlatório do auditório - planta e vista, 1968.

Planta e detalhes - tapetes, 1970. 


\section{FUNDOS E ACERVOS CONSULTADOS}

Acervo Bernardo Figueiredo

Acervo do arquiteto Milton Ramos

Acervo do Itaú Cultural

Acervo Norberto Nicola

Arquivo da Câmara dos Deputados

Arquivo do Museu de Arte Brasileira da Faculdade Armando Alvares Penteado (MAB-FAAP)

Arquivo do Senado Federal

Arquivo Histórico do Museu de Arte de São Paulo (MASP)

Arquivo Histórico Wanda Svevo da Fundação Bienal de São Paulo

Acervo on-line Casa Lúcio Costa

Acervo on-line da Brown University - Opening the Archives Documenting U.S.-Brazil Relations, 1960s-80s

Centro de História e Documentação Diplomática

Fundação Athos Bulcão

Instituto de Arte Contemporânea (IAC)

Instituto Moreira Salles (IMS)

Instituto Sergio Rodrigues

IPHAN-DF

Hemeroteca Digital da Biblioteca Nacional

Setor de Arquitetura do Ministério das Relações Exteriores (SARQ - MRE) 


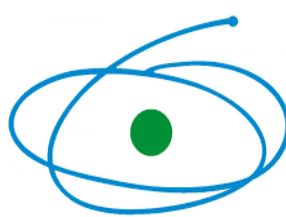

CAPES

C A P E S

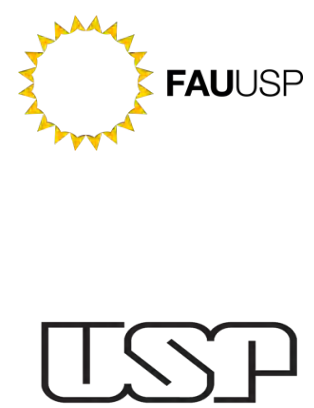

FACULDADE DE ARQUITETURA E URBANISMO

UNIVERSIDADE DE SÃO PAULO

DIAGRAMAÇÃO

CAMILA NERI

TRATAMENTO DE IMAGENS LARISSA CANDRO 
